







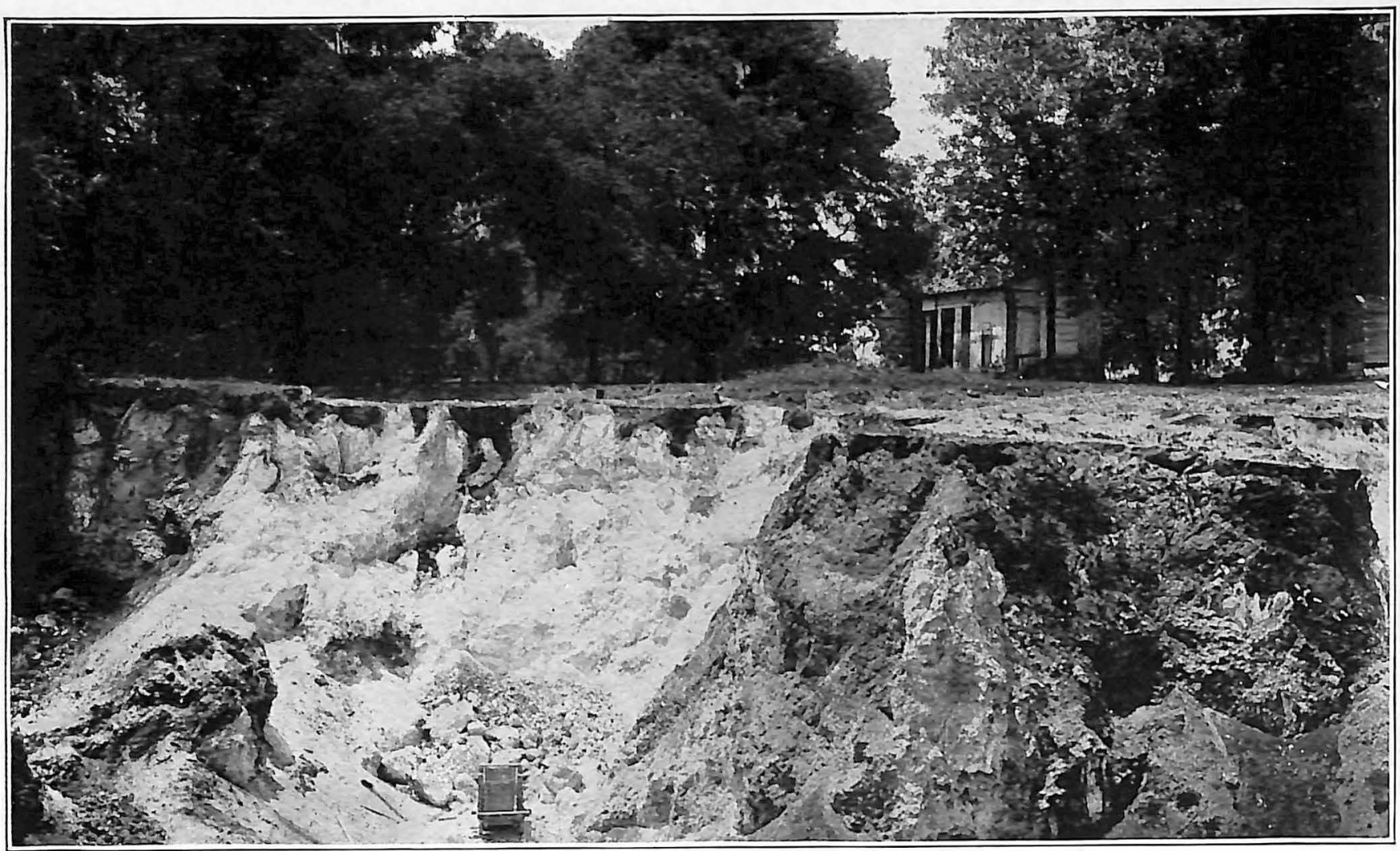

Pit of Florida Lime Company, Ocala, Florida. Type exposure of the Ocala Limestone. 


\section{FLORIDA STATE GEOLOGICAL SLRIEY \\ Hermax Gunter, State Geologist}

\section{SIXTEENTH ANNLAL REPORT}

$19 \cdot 3-19 \cdot+4$

\section{ADMINISTRATIVE REPORT}

MINERAL INDLETRIES

LIMESTONES AND MARLS OH FLORIDA

Publisied for

THE STATE GEOLOGICAL SURVEY

Tallahassee, 1925 

BINDING SLIP

FLORIDA GEOLOGICAL SURVEY

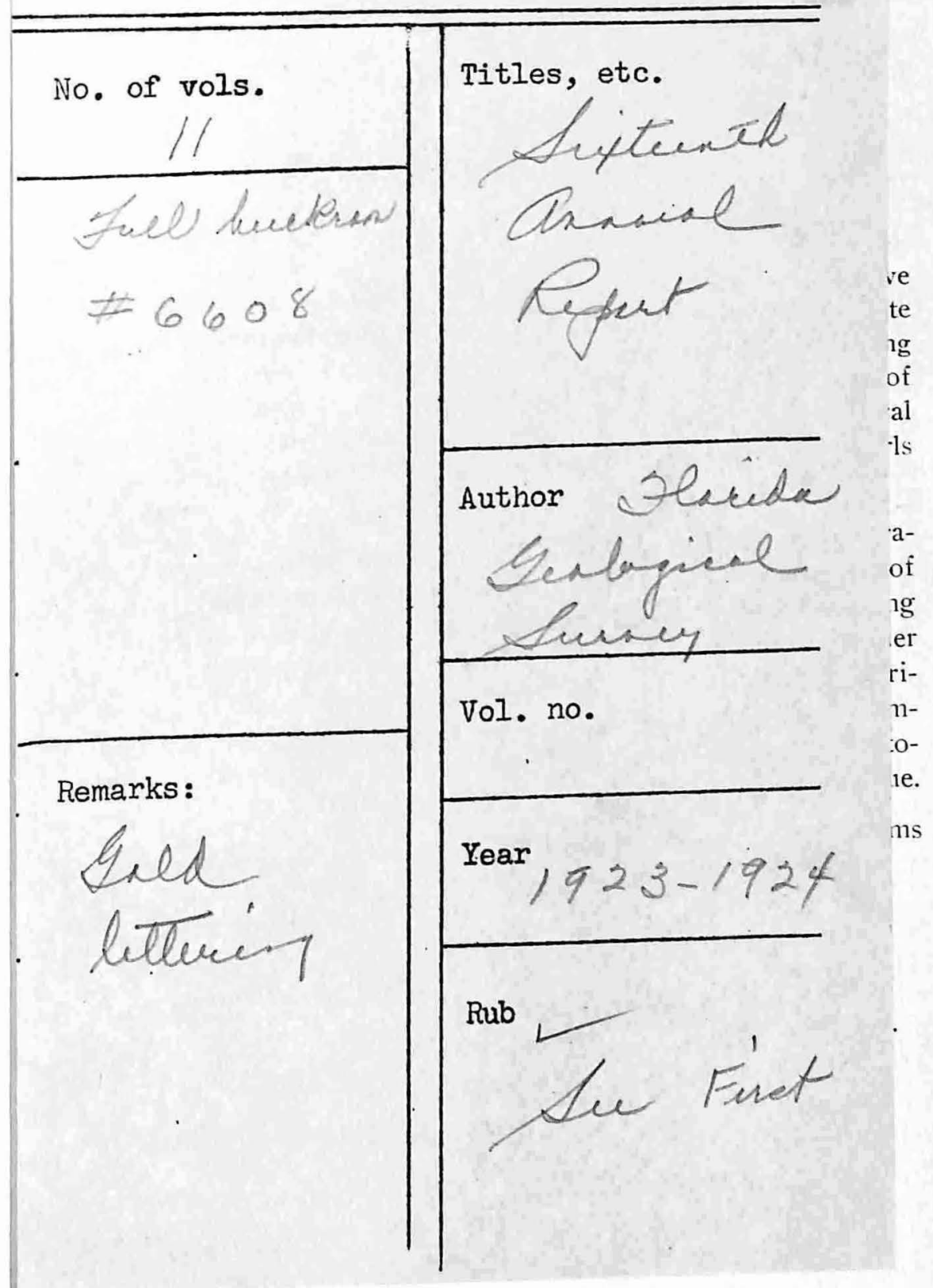




\section{LETTER OF TRANSMITTAL}

To His Excelloney, Hon. Cary A. Harder, Gonernor of Florida:

Sik:-In accordance with the law establishing the Survey, I have the honor to submit herewith the Sixteenth Annual Report of the State Geologist. The work of the Survey has progressed satisfactorily during the year closing June 30,1924 . This report contains a statement of expenditures from July 1,1923 , to June $30,19: 4$; a paper on the mineral industries for the year 1923, and a report on the limestones and marls of the State.

The present report is devoted principally to an economic consideration of a most common mineral resource, namely, limestone and also of marl. The limestone industry has grown very rapidly in Florida during the last few years since it is so largely used as a road material. Other uses are as a building stone, in foundation work, railroad ballast, agriculture and in the manufacture of lime. 'There is another very promising field for its use in this State-that of the cement industry. Altogether it is thought the report is very timely and will be found of value.

The courteous consideration you have always shown those problems with which this Department has to do is very much appreciated.

Very respectfully;

December, 1994 .

Herman Guntror, State Gologist. 
TABLE OF CONTENTS.

PAGE

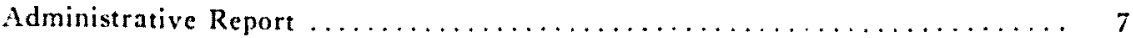

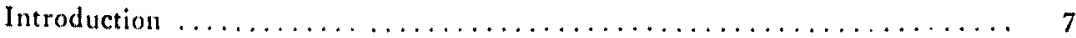

Recommendations ................................

Expenditures of the Survey............................. 12

Statisies on Mineral Production in Florida During 1923, by Herman Gunter.

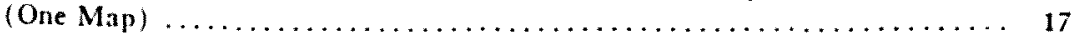

A Preliminary Report on The Limestones and Marls of Florida, by Stuart

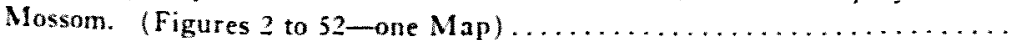




\title{
ADMINISTRATIVE REPORT
}

\author{
Hr:kMAx GeNTrk, State Goologist
}

\section{INTTRODLC'TION}

Establishmont.-The present Geological Survey was created by an Act of the 190\% Legislature. Provision was made for the appointment of a State Geologist and his duties were specified. The objects of the Survey were also outlined and a continuing appropriation of $\$$ s.j00 a year was made for its maintenance.

Present Appropriation.-The law establishing the Survey has in no wise been changed until the Legislature of 1993 appropriated for the maintenance of this Department the sum of $\$ 10,345$ for the fiscal year ending June 30, 19:4, and a like amount for the year ending June 30 , 19.5.). This was apportioned as follows:

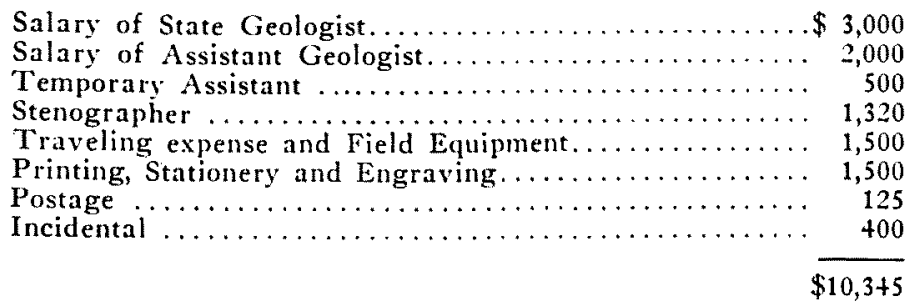

This is an increase of nearly 14 per cent in the amount appropriated annually for the support of the Survey in previous years. As a result it has been possible to more actively prosecute field work and to print an increased number of the annual reports. Although with this slightly increased amount it has been possible to unlertake some of the more urgent field work and to have printed a larger edlition of annual reports, experience is proving that the support is far from adequate. Florida is a large State and is developing at a very gratifying rate, all of which means that there are more demands made upon the Survey now than in former years. The Department is bending every effort to supply the information relative to the natural resources of Florida, but it finds itself at a serious disadvantage in many instances. A measure of the value 
of a public institution is service. To render efficient and satisfactory service a department must have tools with which to work, which in turn means funds for investigations and for getting these results before the public.

Publications of the Surey-The present report constitutes the sixteenth in the series of annual reports issued by the Survey. In adclition two bulletins and twelve press bulletins have been published. These have been distributed to all sections of our own State and Country as well as to some foreign countries. Many of them are now out of print, which indicates the demand for reports having to do with the State's resources.

Distribution of Reports.-The Survey maintains an exchange list to which all its reports are regularly sent. In aldition an active mailing list is made up from those persons returning the card notices which are sent out as each new report is ready for distribution. These publications are not sent broadcast but only to those who return the card notice inclicating their desire for the whole report or any one of the separate papers composing it. The annual reports, in addition to the administrative and statistical sections, deal with stbjects pertaining to the State's varied natural resources. They might, therefore, and often are, made up of several separate papers, each clevoted to some special subject. For this reason the issuing of the report as a whole volume and also having a certain part of the edition issued in the form of the separate papers of which it is composed has proven an economical practice. This obviate: the necessity of sending the entire report to those who might only be interested in one or more of the separate papers. Reports are sent free to the citizens of Florida and upon payment of postage to all others.

Purpose of the Geological Suriey.-The law creating the Floricla Geological Survey specifies some of the purposes for which such a department was organized. Among these was to make known data pertaining to "the minerals, water supply and other natural resources of the State," as well as the "occurrence and location of mineral and other deposits of value, surface and subterranean water supply and power and mineral waters, and the best and most economical methods of clevelopment." The reports of the Survey shall also include "analysis of soils, minerals and mineral waters, with maps, charts and drawings of the same."

In this connection it is appropriate to call attention to the fact that the Geological Survey is the only State Department charged with the 
distribution of information relating to the natural resources just specified. To such extent therefore this Department is the State's clearing-house for making information of this character known. It may be said that the Survey's function is both an educational and an economic one. The collection of mineral and fossil specimens and their exhibition in the Survey's Museum, duplicate sets of which shall be deposited in each of the State Colleges, suggests the very apparent educational value. 'Through an understanding of the geology of the State and its bearing upon the occurrence of mineral and related deposits, the Survey is expected to contribute to and assist in an intelligent development of the State's natural resources. That the Survey has endeavored to be of service the subjects of the reports thus far published stand as evidence. Finthermore, that the work has been effective is shown by the clemand for publications from the Department, many of them now no longer available, and also by the number of letter requests and visits to the office and Museum.

Specimens Submitted for Examination.-The matter of classifying and reporting upon samples of rocks, minerals and fossils found in Florida is one of the functions of the Geological Survey. Citizens are urged to send in specimens of interest which they believe might prove of value and thereby take advantage of this service which has proven useful to many already. This applies not only to mineral specimens but also to fossils. It is perhaps well to call attention to the fact that with the large amount of excavation work in crainage, in mining and in large construction of various kinds, there are being brought to light many remains of vertebrate aninals that were present in prehistoric times. That many of these are lost is evident, but in many instances such remains have excited the curiosity of the finders and have been preserved by them. It.is to be hoped that whenever fossils are found, both large and small, they will be cared for and notification of such finds sent to the State Geologist or the specimens themselves sent in for identification.

\section{RECONMENDATIONS}

Muscum.-In previous reports attention has been called to the fact that Florida should provide for ${ }^{\prime \prime}$ an adequate museum in which to properly exhibit the varied resources. The law creating the Geological Department makes it the duty of the State Geologist to collect, determine and label specimens illustrating the mineral and geological features of 
the State and collections have been made since the Survey was organized. A display of representative mineral specimens and also of many fossils is made in the one room now available and allotted mainly for such purpose. The space, however, is entirely inadequate and a large amount of material suitable for display necessarily remains packed up as collected. It is important that provision be made for the proper preservation and exhibition of material already on hand as well as to care for future accessions and to stimulate interest in collecting and saving the many fossil specimens that are unearthed from time to time.

Clay Testing Laboratory.-A preliminary report upon the clays of Florida has been made and this has proven of very great interest. The clay tests contained in this report were made in the laboratory of the Ceramic Department of Cornell University. That the report has assisted in directing attention to the possibilities of the Florida clays is eviclent from the number of requests made for it and also in the interest shown in examining the test bricklets on display in the museum. Furthermore, there is a continued demand on the part of the citizens for additional clay tests and in order to meet this the State should have a laboratory for testing clays for brick-making and other purposes. In determining the adlaptability of a clay its physical as well as its chemical properties should be known. In order to properly test a clay it is therefore necessary to have testing equipment or machinery. A small but well-equipped laboratory could be installed at an expense approximating $\$ 1500$.

COOPERATION WITH THE UNITED STATES GEOLOGICAL SURVEY AND THE, UNITED STATES BUREAU OE SOILS

Cooperation is carried on between the U. S. Geological Survey and the State Survey in the matter of the collection of statistics on the mineral production. This is very satisfactory; not only is it a saving in expense but it assures uniformity of reports on the mineral output of the State. It is urgently recommended that cooperation with the U. S. Geological Survey to a greater extent be made possible. There should be an annual fund available for this purpose. Such subjects as topographic mapping, the gaging of streams in order that data might be available for prospective power development as well as to get clata relative to flood control, the matter of the quality of our underground waters, and other subjects, could be arranged for report on a cooperative basis. 
The U. S. Geological Survey will meet the State Survey in work of this nature upon a basis of an equal expenditure of funds.

There is an urgent demand for soil work in Florida. The L.S. Bureau of Soils will cooperate with a State organization in mapping soils. The Florida Survey has in former years cooperated with the Bureau of Soils. but such work, owing to limited funds on the part of the State Surver, had to be discontinued. With the continued rapid development that Florida is making there comes a more insistent demand for information regarding the soils of the different sections. It is recommended that a fund of $\$ 5,000$ annually be made available for cooperation with the $[$. S. Burean of Soils. Such an appropriation may be made contingent upon cooperation with the national burean and would thus result in the annual expenditure of $\$ 10,000$ in the State for this purpose. 


\section{EXPENDITURES OF THE GEOLOGICAL SURVEY FROM JULY 1, 1923, TO JUNE, 30, 1924}

The following itemized list shows the expenditures of the Survey from July 1, 1923, to June 30,1924 . The total annual appropriation during this period was $\$ 10,34 \overline{5}$. All bills and itemized expense accounts are on file in the office of the Comptroller, duplicate copies being retained in the office of the State Geologist.

\section{LIST OF WARRANTS ISSUED FROM JULY 1, 1923, TO JUNE 30, $192+$}

JULY, 1923.

Herman Gunter, State Geologist, salary..............\$250.00

Herman Gunter, State Geologist, expenses. . . . . . . . . . . $\quad 4+90$

R. M. Harper, Assistant, salary, part of July ... . . . . . $\quad 37.64$

Florence M. Epperson, Stenographer, salary............ 110.00

Sam E. Cobb, Jr., services........................ 65.00

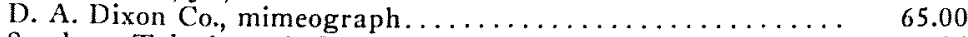

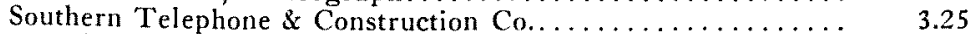

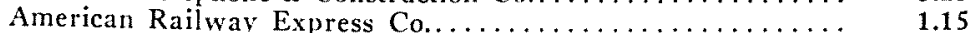

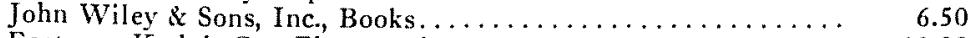

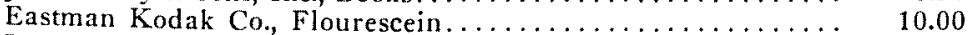

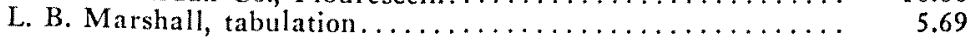

August, 1923.

Herman Gunter, State Geologist, salary.............\$ 250.00

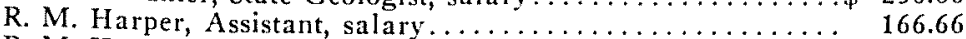

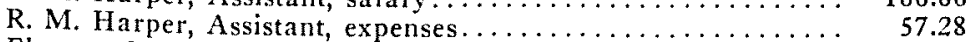

Florence M. Epperson, Stenographer, salary ............ 110.00

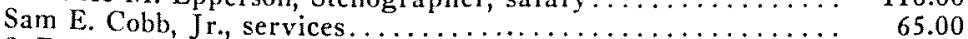

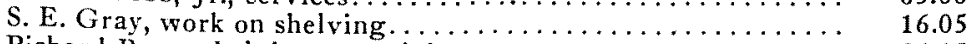

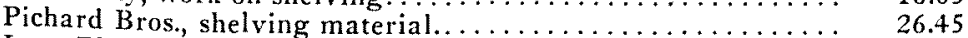

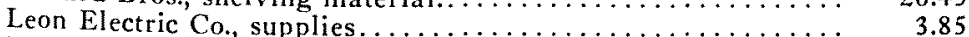

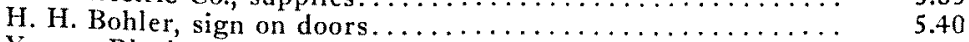

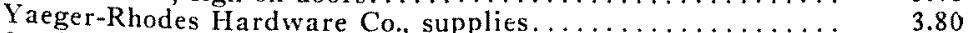

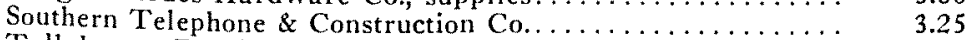

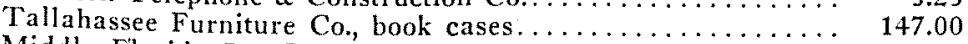

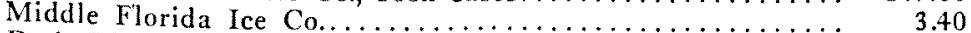

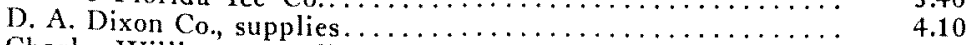

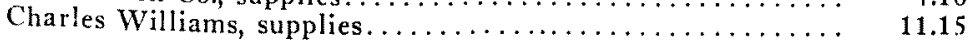

SEPTEMBER, 1923.

Herman Gunter, State Geologist, salary............\$ 250.00

Herman Gunter, State Geologist, expenses, August and Sept... 130.52

R. M. Harper, Assistant, salary, part of September .......... 38.89

Florence M. Epperson, Stenographer, salary............ 110.00

Sam E. Cobb, Jr., services, part of September............. 13.00

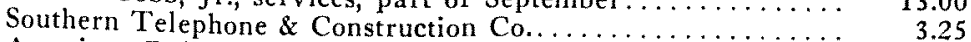

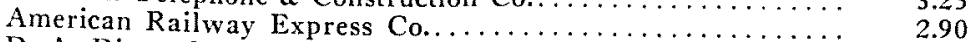

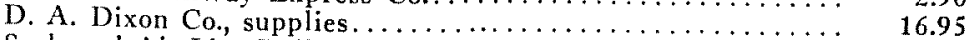

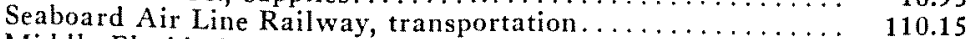

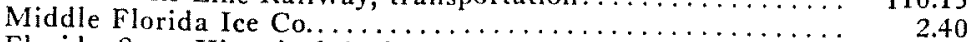

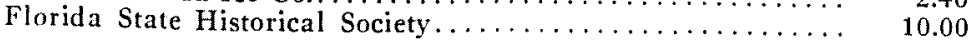


OCTOBER, 1923.

Herman Gunter, State Geologist, salary.............\$250.00

Herman Gunter, State Geologist, expenses.............. 16.80

Florence M. Epperson, Stenographer, salary............ 110.00

Southern Telephone $\&$ Construction Co............... $\quad 3.25$

D. A. Dixon Co., supplies........................ 11.25

Wrigley Photo-Engraving Corporation, chart.......... 5.31

Engineering \& Mining Journal-Press............... $\quad 8.00$

The American Fertilizer......................... 3.00

The Oil Weekly.................................. 1.00

Middle Florida Ice Co........................ 2.30

November, 1923.

Herman Gunter, State Geologist, salary..............\$250.00

Herman Gunter, State Geologist, expenses............. 46.93

Florence M. Epperson, Stenographer, salary........... 110.00

Olin G. Bell, expenses......................... 132.84

Southern Telephone $\&$ Construction Co............... 3.25

American Railway Express Co...................... 2.44

DECEMBER, 1923.

Herman Gunter, State Geologist, salary .............\$250.00

Florence M. Epperson, Stenographer, salary........... 110.00

Southern Telephone \& Construction Co................. 3.25

D. A. Dixon Co., supplies...................... 1.50

Wrigley Photo-Engraving Co., zinc etching............. 5.50

American Railway Express Co......................., 1.25

E. Leitz, Inc., 1 Binocular Magnifier................. 61.98

JANUARY, 1924.

Herman Gunter, State Geologist, salary............\$ 250.00

Herman Gunter, State Geologist, expenses.............. 91.68

D. Stuart Mossom, Assistant, salary ............... 166.66

D. Stuart Mossom, Assistant, expenses............... 96.26

R. M. Harper, Assistant, salary................. 166.66

R. M. Harper, Assistant, expenses................... 62.80

Florence M. Epperson, Stenographer, salary............ 110.00

Southern Telephone \& Construction Co............... 3.25

Service Print Shop ........................... 17.75

FEBRUARY, 1924.

Herman Gunter, State Geologist, salary............\$ 250.00

D. Stuart Mossom, Assistant, salary ................ 166.66

D. Stuart Mossom, Assistant, expenses............ 44.46

D. Stuart Mossom, Assistant, auto mileage............ 67.50

R. M. Harper, Assistant, salary.................. 166.66

Florence M. Epperson, Stenographer, salary........... 110.00

Southern Telephone $\&$ Construction Co................ 3.25

H. \& W. B. Drew Co., supplies.................... $\quad 6.12$

Florida State Historical Society, publication............ 11.00

Economic Geology Publishing Co., subscription........... $\quad 4.00$

W. H. May, Postmaster, stamps................... $\quad 50.00$

March, 1924.

Herman Gunter, State Geologist, salary........... \$250.00

Herman Gunter, State Geologist, expenses............. $60 .+6$ 
D. Stuart Mossom, Assistant, salary............... 166.66

D. Stuart Mossom, Assistant, expenses............. $\$ 6.05$

D. Stuart Mossom, Assistant, auto mileage............ 169.70

R. M. Harper, Assistant, salary................ 166.66

R. M. Harper, Assistant, expenses............... 76.53

Florence M. Epperson, Stenographer, salary.......... 110.00

Southern Telephone \& Construction Co.................. 3.25

American Railway Express Co..................... 15.09

D. A. Dixon Co., supplies.................... 2.95

L. B. Marshall, copying tabulation................ 4.50

A. R. Livingston, map southern Florida.............. $\quad 5.00$

Western Union Telegraph Co................... 2.97

APRIL, 1924.

Herman Gunter, State Geologist, salary............\$250.00

D. Stuart Mossom, Assistant, salary................... 166.66

Florence M. Epperson, Stenographer, salary ............ 110.00

Southern Telephone \& Construction Co............... 3.25

American Railway Express Company................... $\quad 9.09$

D. A. Dixon Company, supplies.................. $\quad 6.00$

Florida Democrat, double cards $(3,000) \ldots \ldots \ldots \ldots \ldots \ldots .20 .00$

T. J. Appleyard ..................................

W. H. May, Postmaster, stamps.................... 75.00

W. C. Dixon, freight and drayage $(15$ th Annuals $) \ldots \ldots \ldots \ldots .+5.15$

MAY, 1924.

Herman Gunter, State Geologist, salary..............\$250.00

D. Stuart Mossom, Assistant, salary...................... 166.66

Florence M. Epperson, Stenographer, salary............. 110.00

Southern Telephone \& Construction Co.................. $\quad 3.25$

American Railway Express Company.................... 6.48

The Record Company, printing 15th Annual Report.......... $1,879.69$

Commercial Fertilizer, subscription................... 2.00

University of Chicago Press, subscription............... 3.60

JUNE, 1924.

Herman Gunter, State Geologist, salary...............\$ 250.00

Herman Gunter, State Geologist, expenses............... 38.90

D. Stuart Mossom, Assistant, salary.................... 166.66

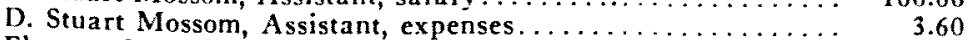

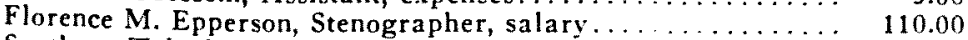

Southern Telephone \& Construction Co................. 3.25

American Railway Express Company ....................

D. A. Dixon Company, supplies..................... 33.40

W. H. May, Postmaster, stamped envelopes............. 91.68

Grant Furniture Company........................... $\quad 39.00$

Wm. Ainsworth \& Sons, Brunton Compass............... $\quad 32.50$

Wagner Free Institute of Science, Veg. of South Florida ..... 2.50

Rand McNally \& Company, 1 Atlas................... 9.06

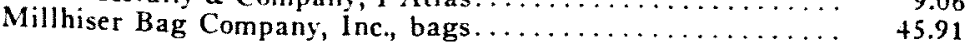




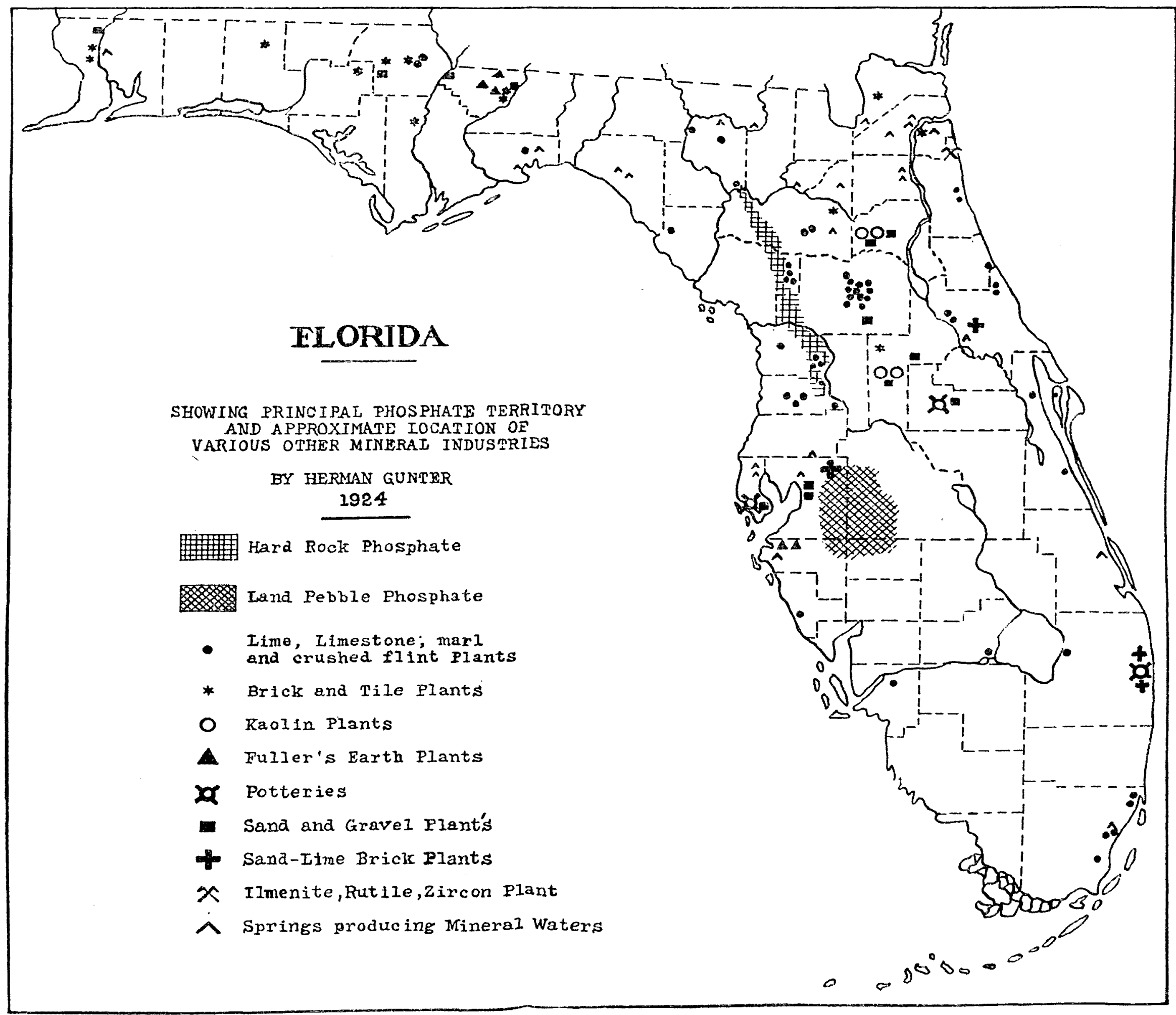






\section{STATISTICS ON MINERAL PRODLCTION IN FLORIDA DURING 19:3}

Heir Max GuNTer

Collected in Cooperation sith the United States Geological Surecy and the U.S. Burcau of Census

The total value of the mineral output in Florida during 1923, as shown by returns from the producers, was $\$ 13,230,099$. This is $\$ 1,785$.026 more than the total value of production for 1922. or an increase of a little over 15 per cent. The larger volume of increase comes from the phosphate and the limestone industries, as can be seen by reference to the table at the end of this chapter. The outstanding feature in the State's mineral industries was the remarkable development made by the limestone industry. The returns for $\mathbf{1 9 : 3}$, as compared with those for $19 \cdot 2$. , show an increase of 98 per cent. Comparable to this are the returns made for sand and gravel showing 96 per cent increase and for crushed flint rock of 142 per cent. Since these products, limestone, crushed flint and sand and gravel, enter so largely in the construction of our highways as well as other structural purposes, these figures reflect the rapid development that Florida is making. The mineral industries of the State as a whole. as judged from the statistical returns, showed decided improvement and enjoved a very satisfactory business year, some of them to the extent of establishing new high records of production.

\section{CLAX}

The kaolin industry of Florida, which is centered in Putnam and Lake counties, was very active as is indicated by a 28 per cent increase in the value of the 1923 production over that for 1922. Another feature is the preparation being made for the opening of a new mine at Crossley, Putnam County, by the United Clay Mines Corporation of Trenton: N. J. The Florida kaolin is an exceptionally high grade, very plastic, white burning clay. The washed clay is shipped to potteries of the 
sorthern States where it enters into the manufacture of the higher grate white wares.

Owing to the limited number of producers, production figures and value are not given separately but they are included in the total for the State.

KAOL.IN PRODUCERS, 1923

Edgar Plastic Kaolin Company, Metuchen, N. J., and Edgar, Fla.

Florida China Clay Co., Inc., Leesburg, Fla.

Lake County Clay Co., Metuchen, N. J., and Okahumpka, Fla.

\section{CLAY PRODUCTS}

There are a number of clay-working plants in Floricla producing principally common building brick. Some of the plants, however, manufacture hollow building tile, drain tile and face brick. There are also two potteries in the State producing art pottery of various shapes, suct as vases, bowls and other artistic cla! pieces. Although the pottery industry is a comparatively new one in the State, it constituted a little more than 5 per cent of total value of clay products in 1 !):?. The total value of the output of all clay products was $42.26,38 ;$, which is a per cent more than that recorled for $19 \% 2$.

BRICK AND THLE pRODUCERS, 1923

The Build-With-Brick Company, Molino, Escambia County.

J. M. \& J. C. Craber, Campville, Alachua County.

E. M. Davis, Lawrence, Gadsden County. (P. O. Ocklocknee.)

Dolores Brick Company, Molino, Escambia County.

Florida Industrial School for Boys, Marianna, Jackson County.

Gamble \& Stockton Company, Jacksonville, Duval County.

Glendale Brick Works, Cilendale, Wation County.

G. C. \& G. H. Guilford, Blountstown, Calhoun County.

V. J. Hall \& Son, Chipley, Washington County.

Hull \& Cowan Company, Callahan, Nassau County.

Keystone Brick Company, Whitney, Lake County.

Tallahassee Pressed Brick Company, Havana, Gadsden County.

POTTERT PRODUCERS, 1923

Florida Pottery, 2107 Fourth St., St. Petersburg, Pinellas County.

Orlando Potteries, Orlando, Orange County.

\section{IVLLER'S FUKTII}

Fuller's earth is a clay possessing the peculiar properties of absorbing coloring matters and through the process of filtration removing these from mineral, anmal and vegetable oils and fats. The Florida earth is largely used in the refining of mineral or petroleum oils, but it is also used to some extent in the clarifying of vegetable and animal oils. Ac- 
cording to the United States Geological Survey fuller's earth is "said to be used in the manufacture of pigments for printing wall paper, in detecting certain coloring matters in some food products, as a substitute for talcum powcler, and in medicine as a poultice and as an antidote for alkaloid poisons." "*

In the output of fuller's earth Florida maintains first place (as it has since the beginning of the industry) in the list of States from which commercial production is reported. Although the tonnage and value is not given separately it is included in the total for the State. The Southern States supply nearly all the domestic earth and of these Floridla, Georgia and Texas are the leading, being credited with 92 per cent of the 1923 production.

FULLER'S EARTH PRODUCERS IN 1923

Attapulgus Clay Company, Ellenton, Manatee County.

Floridin Company, Quincy and Jamieson, Gadsden County.

Fuller's Earth Company, Midway, Gadsden County.

Manatee Fuller's Earth Corporation, Ellenton, Manatee County.

\section{ILMENITE AND ZIRCON}

The production of ilmenite in Florida was begun by Buckman and Pritchard, Inc., at Mineral City, about five miles south of Pablo Beach, Duval County, in 1916. This industry has continued and increased until Florida is now ranked as one of the leading States in the output of this mineral.

The sands along the Atlantic Coast of Florida to and probably south of Palm Beach County contain ilmenite in varying proportions. It is recovered, however, at only the locality mentioned where the sands are sufficiently rich to warrant operations on a commercial scale. Minerals other than ilmenite also occur and of these a small output of rutile, zircon and monazite have at various times been reported. During the year 1923, however, ilmenite and zircon were the only two products reported.

Ilmenite is now largely used in the manufacture of white titanium oxide, a pigment used in paints and also for the manufacture of certain special grades of steel and other alloys. Zircon finds its chief use as a refractory material, as for instance, in the manufacture of crucibles, porcelain wares having to withstand high temperatures such as spark plugs and electrical insulation and vitrified enamels. With continued

*Fuller's Earth in 1923, by Jefferson Middleton; U. S. Geol. Surv., Mineral Resources of the United States, 1923-Pt. II. Oct. 17, 1924. 
investigation and experimentation the uses of zircon will no cloubt be extended. The 1923 production figures indicate a 35 per cent increase over those for 1922 and although these are not separately given they are included in the State total mineral valuation.

\section{LIMESTONE, LIME AND FLIN'T}

The output of limestone in Florida in 1923 amounted to $1,+12,+10$ tons and was valued at $\$ 1,236,226$. These figures indicate an increase of 115 per cent in quantity and 98 per cent in value over 1922. 'The various purposes for which the limestone was used as reported by the producers, were: Rock material, stone filler as in asphalt and other uses, railroad ballast, riprap, building stone, and agricultural. The figures given indicate the rapid progress Florida is making in the development of permanent roads and along building as well as industrial lines. 'To the above figures for limestone should be added the figures for lime and crushed flint and miscellaneous stone which brings the total production of limestone, quick-lime, hydrated lime, crushed flint rock and miscellaneous stone to $1,507,999$ short tons, valued at $\$ 1,5 \% 2,868$, which shows an increase in output of 82 per cent and of 83 per cent in value over 19:2.

The following companies reported limestone in 1923 :

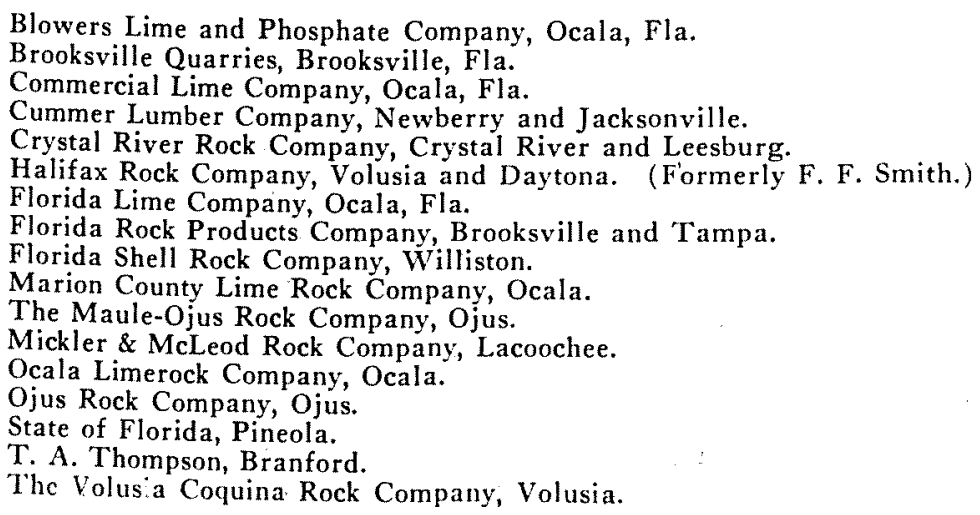


The following companies reported flint or miscellaneous stone production in 1923:

F. J. Baird, Anthony.

Cummer Lumber Company, Newberry and Jacksonville.

Florida Hard Rock Corporation, Ocala.

Levy County Stone Company, Williston.

Long-Pasley Company, Williston.

MeDonald Construction Company, Lakeland.

Polk County Rock, Clay, Sand Company.

A. T. Thomas Company; Ocala.

The following companies reportel lime production in 1923:

Commercial Lime Company, Ocala.

Florida Lime Company, Ocala.

\section{MINFRML WATERS}

The sales of mineral and spring waters in Florida in 1923 were very much greater than in 1992 , there being an increase of 69 per cent in the amount sold and 130 per cent in the value of sales. There were eighteen companies reporting an output of water for commercial purposes in 192:3. The total sales amounted to $1,69 \%, 19 \%$ gallons with a valuation of $\$ 1: 31,281$. Production was reported from the following springs or wells in 1923 :

Bracks-Get-Well-Spring, Bradenton, Manatee County:

Crystal Mineral Spring, White House, Duval County.

Crystal Springs, Crystal Springs, Pasco County.

Deep Rock Spring, West Palm Beach, Palm Beach County.

Egret Springs, Fort Pierce, St. Lucie County.

Espiritu Santo Springs, Safety Harbor, Pinellas County.

Flamingo Spring, Orange City, Volusia County.

Good Hope Mineral Spring, Jacksonville, Duval County.

Gra-Rock Well, Miami, Dade County.

Hampton Springs, Hampton Springs, Taylor County.

Heilbronn Spring, Starke, Bradford County.

Peerless Spring, Miami, Dade County.

Pipkins Mineral Well, Safety Harbor, Pinellas County.

Purity Spring, Tampa, Hillsborough County.

Saint Nicholas Mineral Springs, South Jacksonville, Duval County.

Su-no-wa Spring, Bryceville, Nassau County.

Wi-Wauchula Spring, Jacksonville, Duval County.

\section{PEAT}

Although there are large deposits of peat in Florida, only one plant reported a small production in 1!9:3. The peat marketed was sold as a fertilizer ingredient. The value of the output is included in the total value of the State's mineral production. 
The following are producers of peat in Florida:

F'lorida Humus Co., 14 Wall St., New York, and Zellwood, Florida.

Robert Ranson, St. Augustine, Florida. Florida.

Standard Agricultural Chemical Corp., 2 Rector St., New York, and Fellsmere,

\section{PHOSPHATE}

The quantity of phosphate produced in Florida during 1923, as compared with the quantity for $192 \%$, increased a little over 23 per cent. In comparative value, however, there was an increase of approximately only 9 per cent. By reference to records of past years it is seen that the 1923 output was very nearly the same as for 1913 . The value. however, for the latter mentioned year was about 5 per cent greater than in 1923 . The reported total production for 1923 was $2,547,653$ long tons with a valuation of $\$ 9,059,42 \%$.

In the hard rock district conditions remained about as for the year 1922. Practically all of the hard rock phosphate is exported and conditions in Europe, while in a measure improved, were far from normal. There is, however, an apparent great need for phosphate in Europe, so pressing in fact that the 1923 output amounted to 6 per cent more than for 1922 ; but in value there was a decrease of 22 per cent.

Separate statistics on the production of soft rock phosphate begin in 1918. The maximum reported output came the following year, since which time production has gradually decreased until in 1923 no returns were made for this variety of phosphate.

Land pebble phosphate constituted 92.3 per cent of the 1923 output and 88 per cent of the total value of phosphate produced in Florida. Although conditions were far below normal in the pebble fields they were much better than in the hard rock district. In 1923 pebble phosphate showed an increase of 20 per cent in output and 12 per cent in value over that of 1922 .

Florida produced more than four-fifths, or 85 per cent, of the phosphate sold in the United States in 1923. Other States reporting production of phosphate were Tennessee, Kentucky, Iclaho and Wyoming.

The following table gives the production and value of Florida phosphate rock from 1900 to 1923 , inclusive. Since the beginning of phosphate mining in 1888 to the close of 1923 Florida has produced 46,626 ,$1 \% 2$ long tons with a total valuation of $\$ 184,156,669$. These figures are in accordance with statistics collected by the United States Geological Survey and the Florida Geological Survey. 
Prodection and Value of Phosphati: Rock is Flormdi, 1900-1983.

(Long Tons)

\begin{tabular}{|c|c|c|c|c|c|c|c|c|c|c|}
\hline \multirow{2}{*}{ Year } & \multicolumn{2}{|c|}{ Land Pebble } & \multicolumn{2}{|c|}{ Hard Rock } & \multicolumn{2}{|c|}{ River Pebble } & \multicolumn{2}{|c|}{ Soft Rock } & \multicolumn{2}{|c|}{ Total } \\
\hline & Quantity & Value & Quantity & Value & Quantity & Value & Quantity & Value & Quantity & Value \\
\hline $1900 \ldots$ & $221,+03$ & $1 \$ 612,703$ & $+24,977$ & $\$ 2,229,373$ & 59,863 & $\$ 1+1,236$ & . & $\$ \ldots \ldots$ & $706,2+3$ & $\$ 2,983,312$ \\
\hline $1901 \ldots$ & $247,+54$ & 660,702 & 457,568 & $2,393,080$ & $46,97+$ & 105,691 & & $\ldots \ldots \ldots$ & 751,996 & $3,159,473$ \\
\hline 1902. & 350,991 & 810,792 & $+29,384$ & $1,7+3,69+$ & 5,055 & 9,711 & & $\ldots \ldots \ldots$ & $785,+30$ & $2,56+, 197$ \\
\hline 1903. & 390,882 & $885,+25$ & $+12,876$ & $1,988,2+3$ & 56,578 & 113,156 & & $\ldots \ldots$ & 860,336 & $2,986,824$ \\
\hline $1904 \ldots$ & $+60,834$ & $1,102,993$ & 531,081 & $2,672,184$ & 81,030 & 199,127 & & $\ldots$ & $1,072,951$ & $3,97+, 304$ \\
\hline $1905 \ldots$ & 528,587 & $1,0+5,113$ & 577,672 & $2,993,732$ & $87,8+7$ & 213,000 & & $\ldots$ & $1,194,106$ & $4,251,8+5$ \\
\hline $1906 \ldots$ & $675,+4+$ & $2,029,202$ & 587,598 & $3,440,276$ & $+1,+6,3$ & 116,000 & & $\ldots \ldots$ & $1,30+, 505$ & $5,585,578$ \\
\hline 1907. & 675,024 & $2,376,261$ & 646,156 & $+, 065,375$ & 36,185 & 136,121 & & $\ldots$ & $1,357,365$ & $6,577,757$ \\
\hline $1908 \ldots$ & $1,085,199$ & $3,885,041$ & $595,7+3$ & $4,566,018$ & 11,160 & 33,480 & & . & $1,692,102$ & $8,48+, 539$ \\
\hline $1909 \ldots$ & $1,266,117$ & $4,514,968$ & 513,585 & $4,026,333$ & $\ldots \ldots$ & & & $\ldots$ & $1,779,702$ & $8,5+1,301$ \\
\hline 1910. & $1,629,160$ & $5,595,947$ & $438,3+7$ & $3,051,827$ & & & & & $2,067,507$ & $8,6+7,774$ \\
\hline $1911 \ldots$ & $1,992,737$ & $6,712,189$ & $+43,511$ & $2,761,449$ & (a) & (a) & & & $2,+36,2+8$ & $9,473,638$ \\
\hline $1912 \ldots$ & $1,913,418$ & $6,168,129$ & $493,+81$ & $3,293,168$ & (a) & (a) & & & $2,406,899$ & $9,461,297$ \\
\hline $1913 \ldots$ & $2,055,+82$ & $6,575,810$ & 489,794 & $2,987,274$ & (a) & (a) & & & $2,5+5,276$ & $9,563,084$ \\
\hline $1914 \ldots$ & $1,829,202$ & $5,4+2,5+7$ & 309,689 & $1,912,197$ & (a) & (a) & & & $2,138,891$ & $7,354,744$ \\
\hline $1915 \ldots$ & $1,308,+81$ & $3,496,501$ & 50,130 & 265,738 & & & & & $1,358,611$ & $3,762,239$ \\
\hline $1916 \ldots$ & $1,468,758$ & $3,874,+10$ & 47,087 & 295,755 & & & (b) & (b) & $1,515,8+5$ & $4,170,165$ \\
\hline 1917. & $2,003,991$ & $5,305,127$ & 18,608 & 159,366 & & & (b) & (b) & $2,022,599$ & $5,+64,+93$ \\
\hline $1918 \ldots$ & $1,996,8+7$ & $5,565,928$ & 62,052 & 377,075 & & & 8,331 & $1+7,103$ & $2,067,230$ & $6,090,106$ \\
\hline $1919 \ldots$ & $1,360,235$ & $5,149,048$ & $285,+67$ & $2,452,563$ & & & 14,498 & 196,318 & $1,660,200$ & $7,797,929$ \\
\hline $1920 \ldots$ & $2,955,182$ & $14,7+8,620$ & $400,2+9$ & $+, 525,191$ & & & 13,953 & 190,551 & $3,369,38 t$ & $19,46+, 362$ \\
\hline 1921. & $1,599,835$ & $8,60+, 818$ & 175,774 & $1,806,671$ & & & $4,+19$ & 20,153 & $1,780,028$ & $10,+31,6+2$ \\
\hline 1922. & $1,870,063$ & $7,035,821$ & 188,084 & $1,308,201$ & & & $4+6$ & 3,500 & $2,058,593$ & $8,3+7,522$ \\
\hline 1933 & $2,3+8,137$ & $7,987,752$ & 199,516 & $1,071,675$ & & & $\ldots \ldots$ & $\ldots \ldots \ldots$ & $2,5+7,653$ & $9,059,+27$ \\
\hline
\end{tabular}

(a) Included in land pebble.

(b) Included in hard rock. 
PHOSPHATE MINING COMPANIES REPORTING PRODUCTION, 1923

American Agricultural Chemical Company, 2 Rector Street, New York City, and Pierce, Florida. Florida.

American Cyanamid Company, 511 Fifth Avenue, New York City, and Brewster,

Armour Fertilizer Works, Chicago, Illinois, and Bartow, Florida. Florida.

J. Buttgenbach \& Company, 22 Ave. Marnix, Brussels, Belgium, and Dunnellon,

C. \& J. Camp, Ocala, Florida.

Charleston, South Carolina, Mining \& Manufacturing Company, Richmond, Virginia, and Fort Meade, Florida. Florida.

Coronet Phosphate Company, 99 John Street, New York City, and Plant City,

Cummer Lumber Company, 453 St. James Building, Jacksonville, Florida.

Dunnellon Phosphate Company, 106 East Bay Street, Savannah, Georgia, and Dunnellon, Florida.

Florida Phosphate Mining Corporation, P. O. Box 1118, Norfolk, Virginia, and Bartow, Florida.

Holder Phosphate Company, 3352 Jefferson Avenue, Cincinnati, Ohio, and Inverness, Florida.

Independent Chemical Company, Inc., 33 Pine Street, New York City, and Bowling Green, Florida.

International Agricultural Corporation, 61 Broadway, New York City, and Mulberry, Florida.

Loncala Phosphate Company, Ocala and Floral City, Florida.

Morris Fertilizer Company, 801 Citizens \& Southern Bank Building, Atlanta, Georgia, and Bartow, Florida.

Mutual Mining Company, 102 East Bay Street, Savannah, Georgia, and Floral City, Florida.

Peninsular Phosphate Corporation, 215 Fourth Avenue, New York City, and Fort Meade, Florida. Florida.

Phosphate Mining Company, 110 William Street, New York City, and Nichols,

Southern Phosphate Corporation, 25 Broad Street, New York City, and Mulberry, Florida.

Southern Phosphate Development Company, Inverness, Florida.

Swift \& Company, Union Stock Yards, Chicago, Illinois, and Bartow, Florida. 


\section{SAND AND GRAVEL}

In common with other construction industries the producers of sand and gravel enjoyed a very satisfactory business year. This is reflected by the 108 per cent increase in quantity and 96.3 per cent increase in value. The total production of sand and gravel in 1923 was $513,24.5$ short tons, valued at $\$ 290,08 \%$.

\section{PRODUCERS OF SAND AND GRAVEL, 1923}

Acme Sand Company, Eustis.

Alafia Sand and Shell Company, Tampa.

Escambia Sand and Gravel Corp., Flomaton, Alabama.

Florida Gravel Company, Quincy.

Interlachen Gravel Company, Interlachen.

Lake Weir Crystal Sand Company, Ocala.

Leesburg Sand and Supply Company, Leesburg.

Tallahassee Pressed Brick Company, Havana.

Tampa Sand and Shell Company, Tampa.

White Sand Company, Orlando.

\section{SAND-LIME BRICK}

For a number of years sand-lime brick have been produced in Florida. During 1923 there was an increase of 12 per cent in the number of brick produced and an increase of 18 per cent in value. The production and value are not given separately, but the value is included with the total for the State.

SAND-LIME BRICK COMPANIES, 1923

Bond Sandstone Brick Company, Lake Helen.

Plant City Brick Company, Plant City and Citizens Bank Bldg., Tampa.

Summary of Minferal Production in Florida for 1922 and 1923

\begin{tabular}{|c|c|c|c|c|}
\hline \multirow{2}{*}{ Mineral Product. } & \multicolumn{2}{|c|}{1922} & \multicolumn{2}{|c|}{1923} \\
\hline & Quantity & Value & Quantity & Value \\
\hline Phosphate (long tons) & & & & \\
\hline Land pebble .... & $1,870,063$ & $\$ 7,035,821$ & $2,3+8,137$ & $\$ 7,987,752$ \\
\hline Hard rock. & 188,084 & $1,308,201$ & 199,516 & $1,071,675$ \\
\hline Soft rock & 446 & 3,500 & & \\
\hline Total Phosphates & $2,058,593$ & $\$ 8,3+7,522$ & $2,547,653$ & $\$ 9,059,+27$ \\
\hline $\begin{array}{l}\text { Ball Clay, Fuller's Earth, Peat, Zir- } \\
\text { con, Ilmenite (short tons) ........ }\end{array}$ & $107,68+$ & $\$ 1,666,260$ & 115,990 & $\$ 1,782,71$ \\
\hline Lime, Limestone, Flint (short tons). & 824,150 & 857,913 & $1,507,999$ & $1,572,768$ \\
\hline $\begin{array}{l}\text { Common Brick, Pottery, Tile and } \\
\text { Sand-Lime Brick............ }\end{array}$ & & & & \\
\hline Sand and Gravel (short tor & $246,8+9$ & 147,924 & 513,245 & 290,082 \\
\hline Mineral Waters (gallons). & $1,004,984$ & 57,305 & $1,697,197$ & 131,781 \\
\hline Total Value & & $\$ 11,445,073$ & & $\$ 13,230,099$ \\
\hline
\end{tabular}



A PRELIMINARY REPORT ON THE LIMESTONES AND

MARLS OF FLORIDA

\author{
By \\ Stuart Mossom \\ Assistant State Geologist
}




\section{TABLE OF CONTENTS}

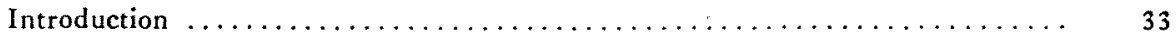

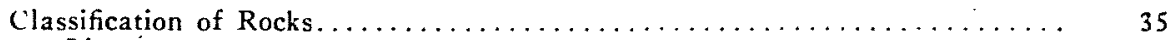

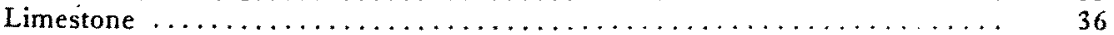

Varieties of Limestone Found in Florida..................

Physical Classification ...................... to

Chemical Classification $\ldots \ldots \ldots \ldots \ldots \ldots \ldots \ldots \ldots \ldots \ldots \ldots \ldots+1$

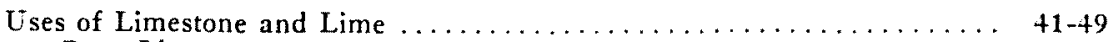

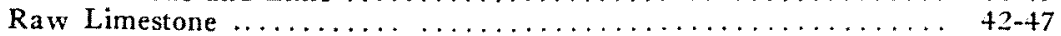

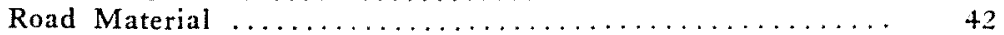

Concrete Aggregate ......................... 43

Railroad Ballast ............................ 43

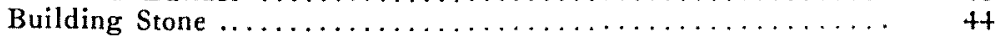

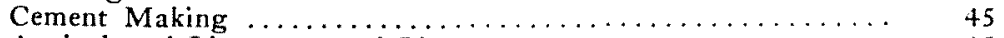

Agricultural Limestone and Lime .................... 45

Quicklime and Hydrated Lime $\ldots \ldots \ldots \ldots \ldots \ldots \ldots \ldots \ldots \ldots$

Sand-Lime Brick .............................. 47

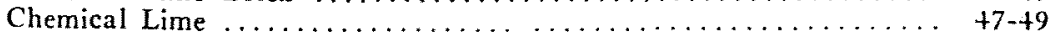

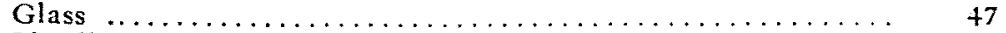

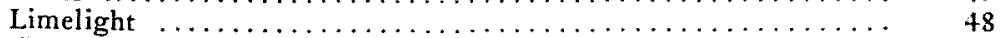

Water Softening ....................... +8

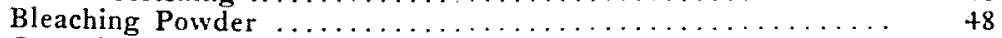

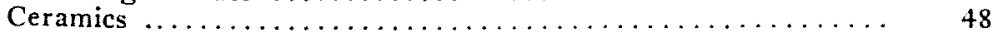

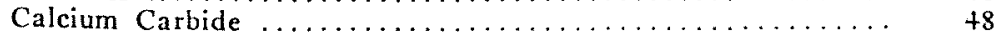

Illuminating Gas and Ammonia $\ldots \ldots \ldots \ldots \ldots \ldots \ldots \ldots \ldots \ldots \ldots \ldots$

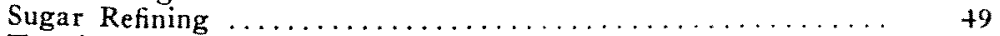

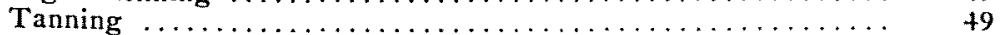

Glycerine, Lubricants, Soaps, etc............... 49

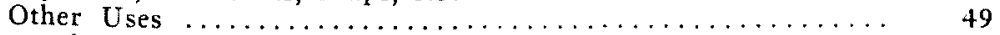

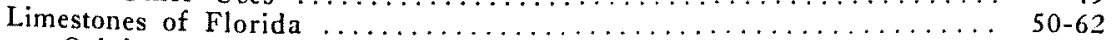

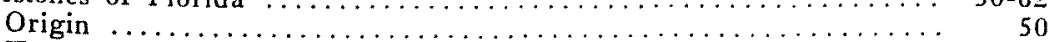

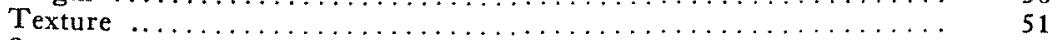

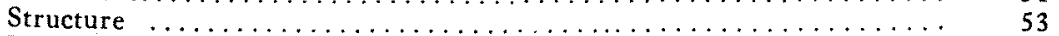

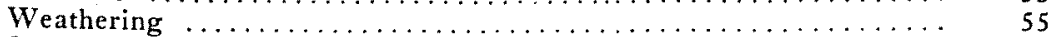

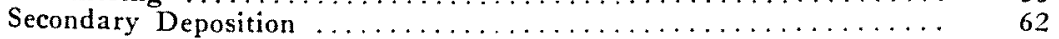

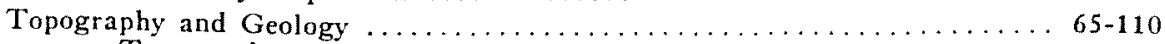

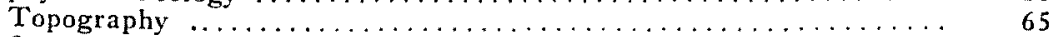

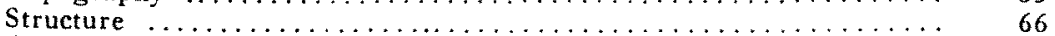

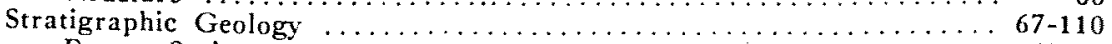

Eocene Series ....................................... 68-70

Ocala Limestone $\ldots \ldots \ldots \ldots \ldots \ldots \ldots \ldots \ldots \ldots \ldots \ldots \ldots . \ldots \ldots$ 68-70

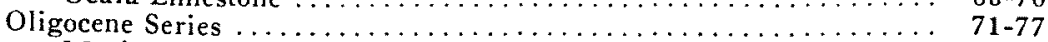

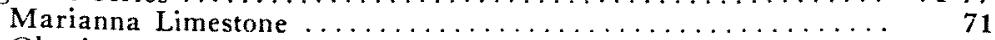

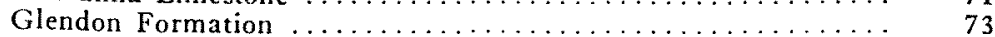

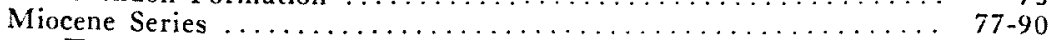

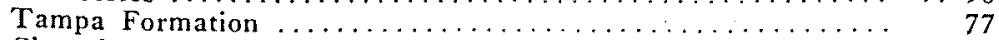

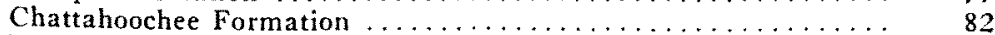

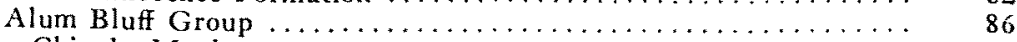

Chipola Marl ............................ 87

Oak Grove Sand .................................. 87

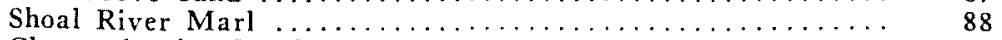

Choctawhatchee Marl ........................... 89

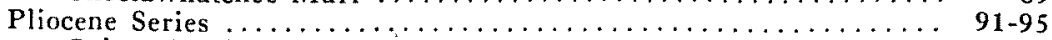

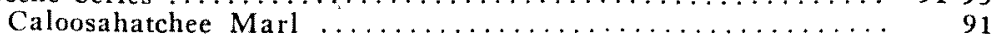

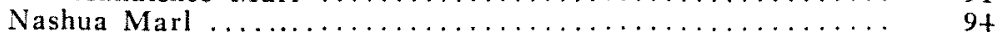


TABLE OF CONTENTS-CONTNUED

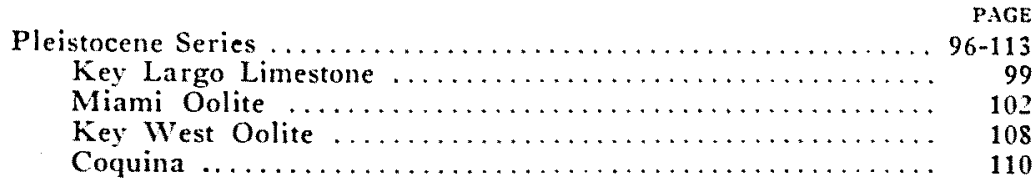

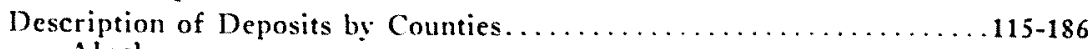

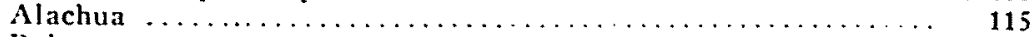

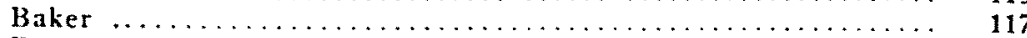

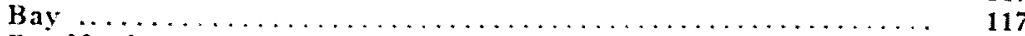

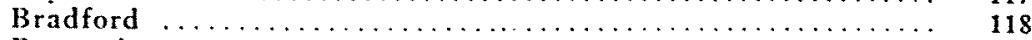

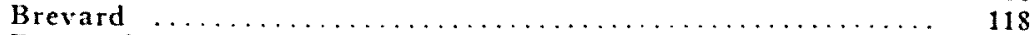

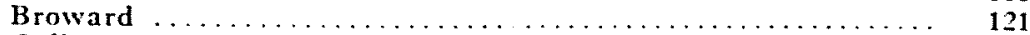

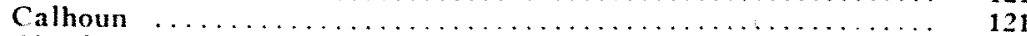

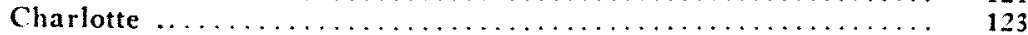

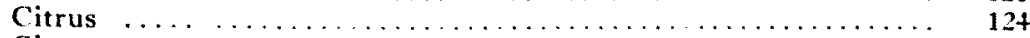

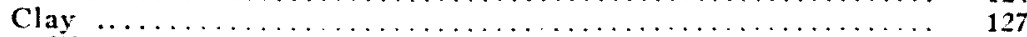

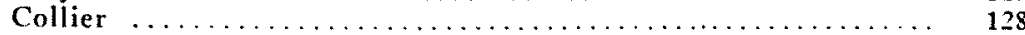

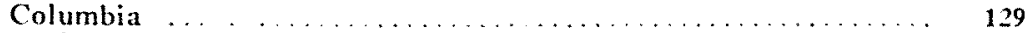

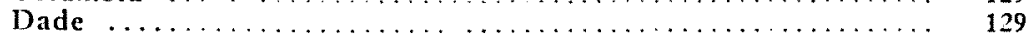

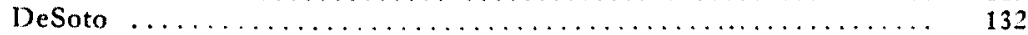

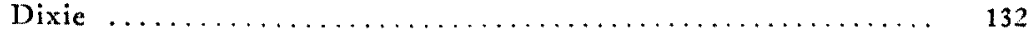

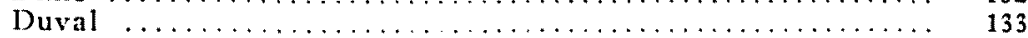

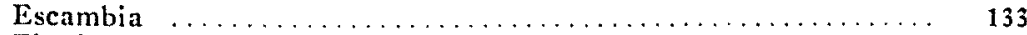

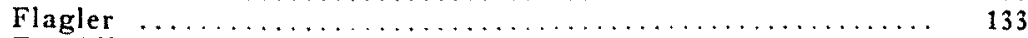

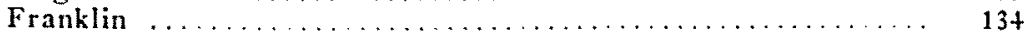

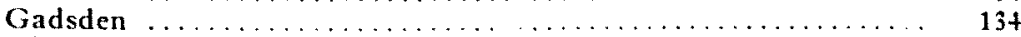

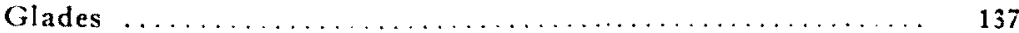

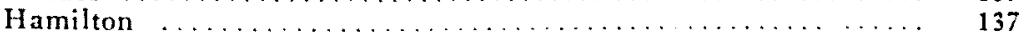

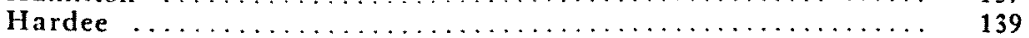

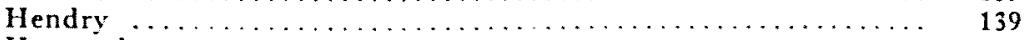

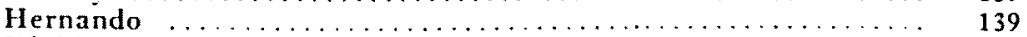

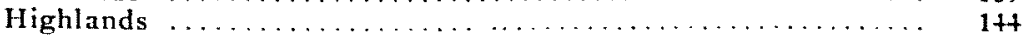

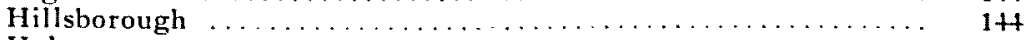

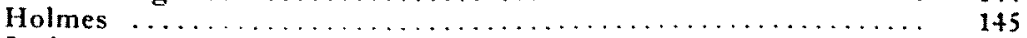

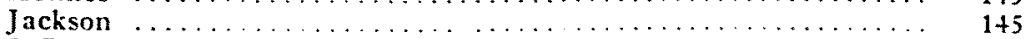

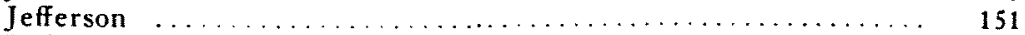

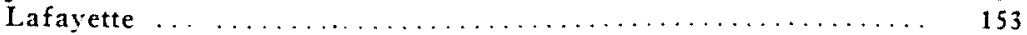

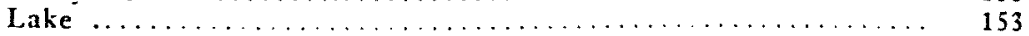

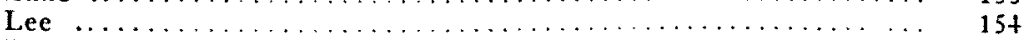

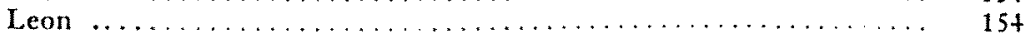

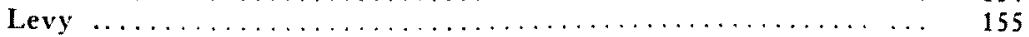

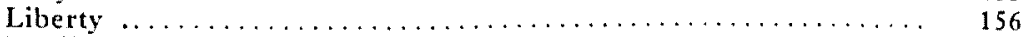

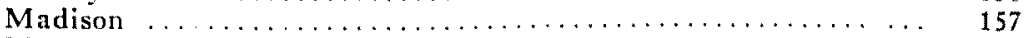

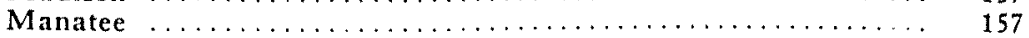

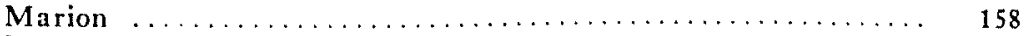

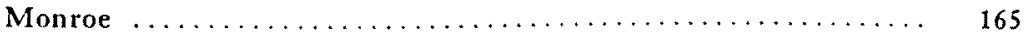

Nassau $\ldots \ldots \ldots \ldots \ldots \ldots \ldots \ldots \ldots \ldots \ldots \ldots \ldots \ldots \ldots \ldots \ldots \ldots \ldots$

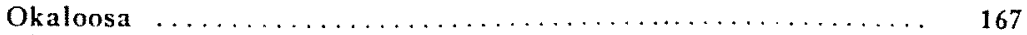

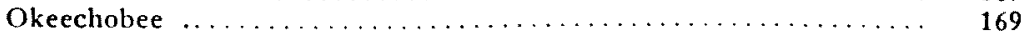

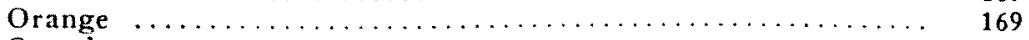

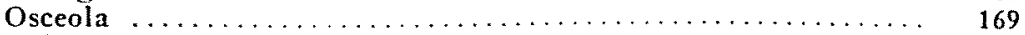

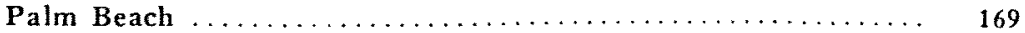

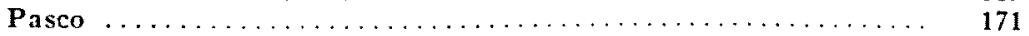

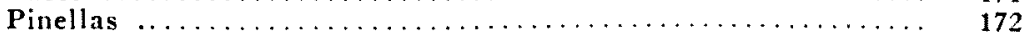




\section{TABLE OF CONTENTS-CONTINUED}

P. 1 E

Polk

Putnam

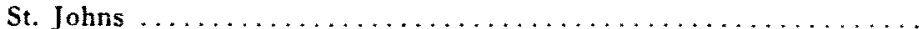

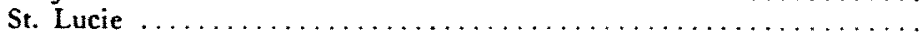

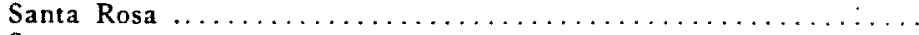

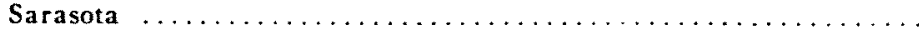

Seminole $\ldots \ldots \ldots \ldots \ldots \ldots \ldots \ldots \ldots \ldots \ldots \ldots \ldots \ldots \ldots \ldots \ldots \ldots \ldots$

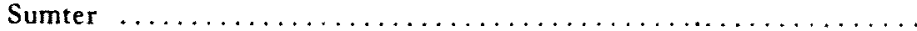

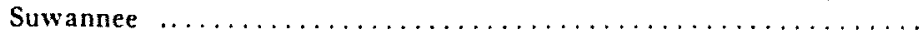

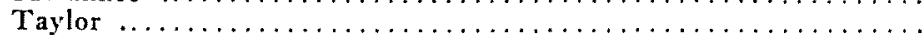

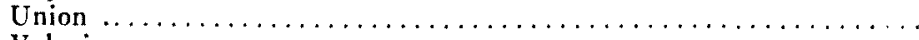

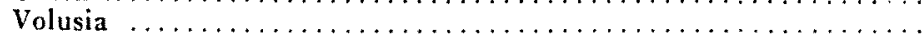

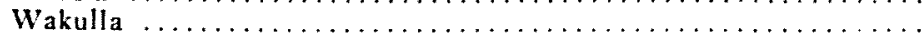

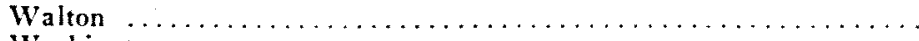

Washington

General Summary

\section{LIST OF ILLUSTRATIONS}

HALF-TONES

in Ocala limestone, near Sumterville, Sumter County....... 32

3. Ocala limestone. Pit of Connell and Schultz, near Pineola, Citrus County 42

4. House built of Key Largo limestone, Islamorada, Monroe County...... +3

5. Quarrying the Miami oolite for building stone near Miami, Dade County it

6. Building constructed of blocks sawed from Marianna limestone. Marianna,

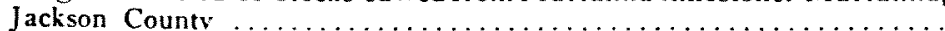

7. Hydrating plant and limestone pit of Florida Lime Company, Zuber,

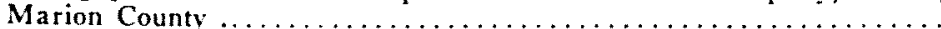

8. Near view of Ocala limestone in Connell \& Schultz pit. Near Pineola,

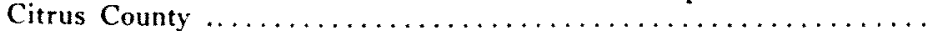

9. Weathered Glendon limestone in sink-hole on Dunn property. Cedar

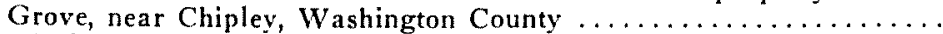

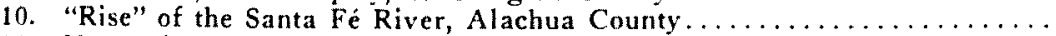

11. Near view of Glendon limestone in Old Lyle quarry, Live Oak, Su-

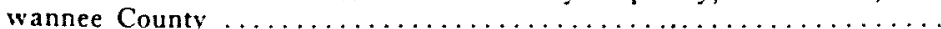

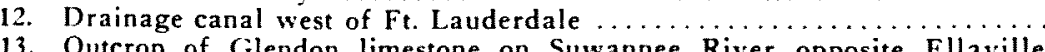

13. Outcrop of Glendon limestone on Suwannee River opposite Ellaville,

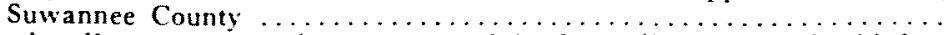

14. Glendon limestone in Falling Water sink, five miles south of Chipley,

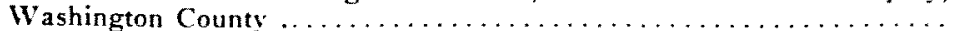

15. Tampa limestone in pit of Florida Rock Products Company, Brooksville, Hernando County

16. Exposure of Chattahoochee limestone on A. C. L. R. R. Near River

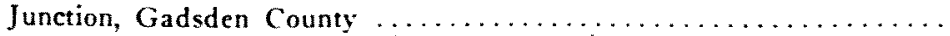

16a. Upper part of Chattahoochee limestone at Victory Bridge (old Chat-

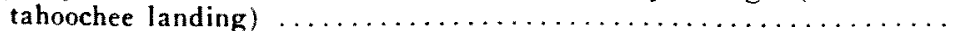

17. Typical exposure of Caloosahatchee beds, (Pliocene), Caloosahatchee River ..............................................

18. Digging Nashua marl for road material, DeLeon Springs, Volusia

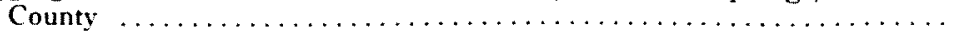

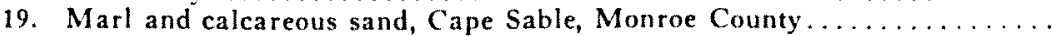

20. Reef rock overlain by marl, Knights Key, Monroe County...............

21. Coral head in Key Largo limestone, Marathon Key, Monroe County.....

22. Drilling dynamite holes in Miami oolite. Naranja pit of Ojus Rock Com-

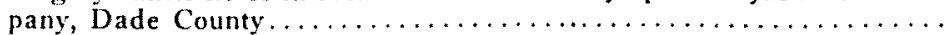




\section{LIST OF ILLUSTRATIONS-CONTINUED.}

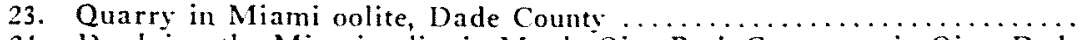

24. Dredging the Miami oolite in Maule Ojus Rock Company pit, Ojus, Dade

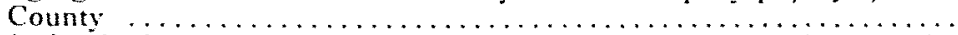

24a. Train load of road material (Miami oolite), Ojus Rock Co. pit, Naranja,

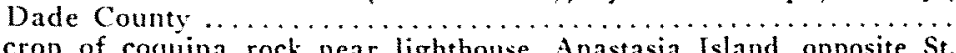

25. Outcrop of coquina rock near lighthouse, Anastasia Island, opposite St.

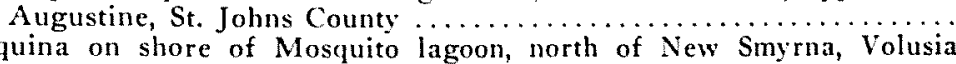

26. Coquina on shore of Mosquito lagoon, north of New Smyrna, Volusia

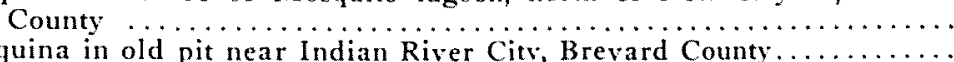

26a. Coquina in old pit near Indian River City, Brevard County ................
27 . Ocala limestone in pit of Gainesville Lime Rock Company, Arredondo...

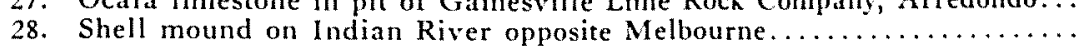

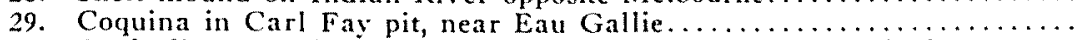

30. Ocala limestone in Crystal River Rock Co. pit near Crystal River.......

30a. Ocala limestone in hard rock phosphate pit, Ft. White...............

31. Exposure of Miami oolite at Silver Bluff, near Miami...............

32. Rear view of dredge in Ojus Rock Company pit, Ojus...............

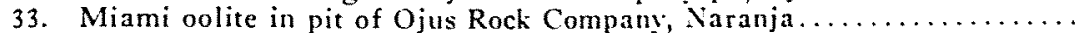

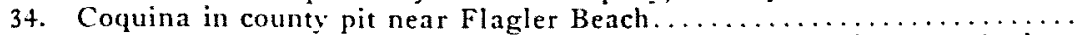

35. Chattahoochec limestone, exposed in pit $1 / 2$ mile east of Insane Asylum,

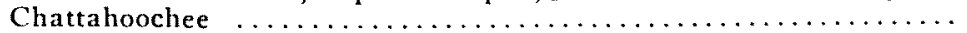

36. Weathered Glendon limestone along the Alapaha river, near Jennings.

37. Plant of the Florida Rock Products Company, Brooksville.............

38. Cutting building blocks from Marianna limestone in pit of R. D. Daffin,

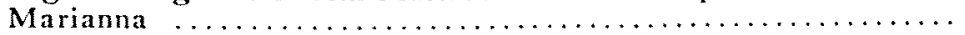

39. Flint rock at the surface in the "Pinhook" section of Jefferson County....

40. Glendon limestone exposed in Miccosukee Drain, $21 / 2$ miles northeast of

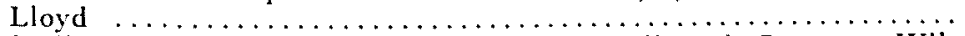

4. Ocala limestone. Pit and crusher of Florida Shell Rock Company, Wil-

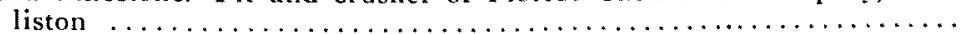

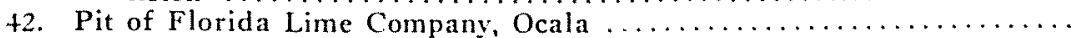

43. Ocala limestone in Ocala Lime Rock Co. pit, Kendrick...............

4t. Florida Lime Company pit No. 2 (old Oakhurst quarry). Ocala.......

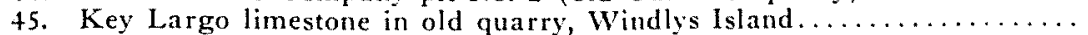

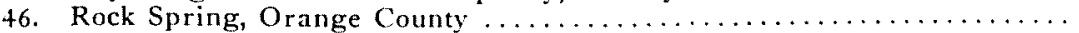

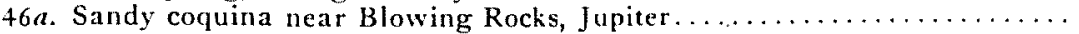

47. Glendon limestone in old Lyle quarry, Live Oak..................

48. Digging coquina in Halifax Rock Company's pit, Volusia............

49. Boulders of limestone dug from shallow depth. Near Woodville........

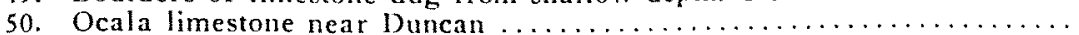

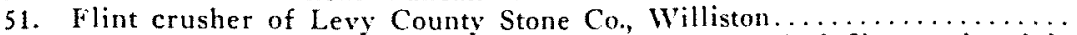

52. Graph showing value of limestone, lime and crushed fint produced in

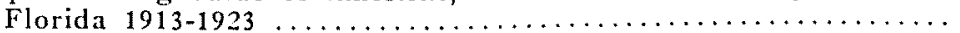

\section{TEXT FIGURES}

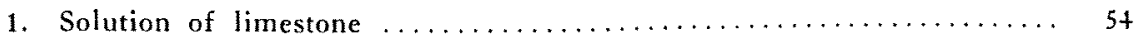

2. Natural bridge formation by means of sink holes................. 58

3. Natural bridge formation by means of sink holes............... 58

4. Natural bridge formation by means of sink holes................ 59

5. Natural bridge formation by means of solution channels............. 61

6. Natural bridge formation by means of solution channels............ 61

7. Natural bridge formation by means of solution channels............ 62

MAP.

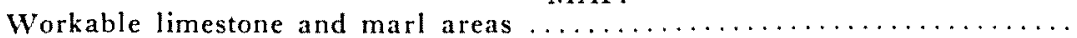




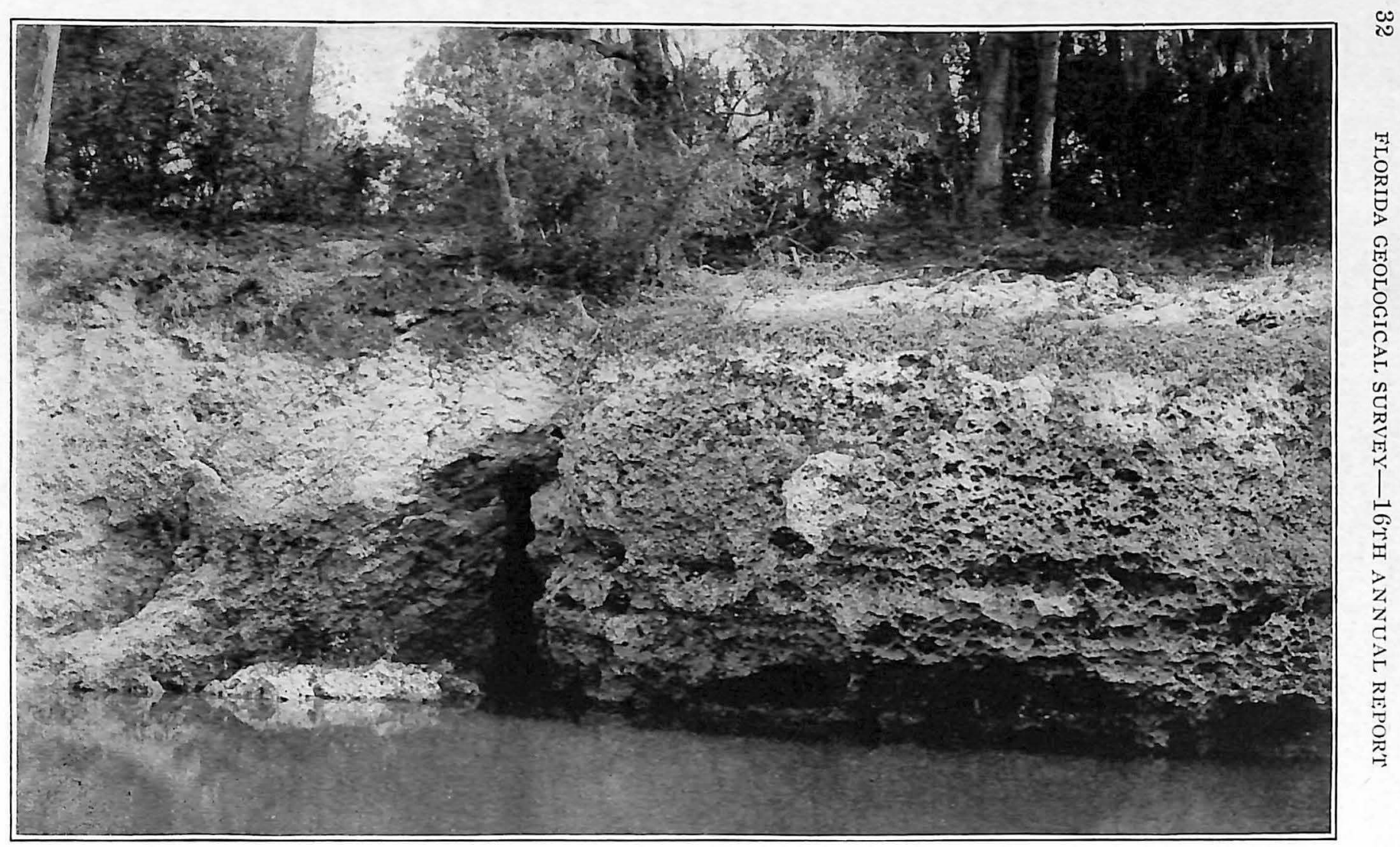

Fig. 2. Wall Sink, in Ocala limestone, near Sumterville, Sumter County. 
A PRELIMINARY REPORT ON THE LIMESTONES AND MARLS OF FLORIDA

\section{INTRODICTION}

This report is intended to bring before the people of Florida, and others interested in that State, some knowledge of the native limestone resources, their general character and distribution. Time and funds did not permit a cletailed study, but it is hoped that this preliminary work will be of value as an introduction to these rocks and will serve as a founclation upon which further investigation may be based.

It was not possible to accurately outline and indicate separate deposits with estimated tonnage available and other information concerning the limestone, for the individual will want to secure stuch data himself before attempting economic development at any given place. The aim of this report, therefore, is to aid such persons by outlining the general areas wherein limestone and marl cleposits in workable quantity occur, and furnishing a brief sketcl of the character of the separate geologic formations that can be recognized in those areas.

Analyses have been made of the material from each formation in different areas and will serve as a guide to the chemical nature of the limestone. The first part of this paper discusses the subject of limestones in general, their origin, classification and uses. The second part takes up the limestones of Florida from several viewpoints and include: a brief outline of the stratigraphy of the State. The last part of the report discusses the limestone and marl cleposits of the State by counties. 
The field work for this report was begun late in February, 1!1\%4, and carried on intermitlently until October; in all about eighteen weeks were spent in the field. During that time all the guarries, pits and known typical exposures were visited and, naturally, many additional locations were found in the course of the survey. At each location a representative sample of the material was taken and from these the more valuable were selected for analysis.

While the calcareous deposits of Florida have previously received no specific attention, a great deal of general stratigraphic and palcontologic work has been done and the results published in reports of the State and national geological surveys as well as in various scientific publications.

The writer has drawn on these different sources freely and given credit in footnote references in each case; the stratigraphic discussion in this report is based largely upon the work of Messrs. G. C. Matson, I. G. Clapp and S. Sanford as published in the Second Annual Report of the Florida Geological Survey.

The writer wishes to express his appreciation of the aid given by many individuals whose information and assistance contributed greatly to the furtherance of this report. Mr. Herman Gunter, State Geologist. and Dr. R. M. Harper of this department, drawing on their knowledge of the State, aided greatly in planning the field work and at all times their friendly criticism was extremely valuable.

Dr. C. Wythe Cooke, of the United States Geological Survey, spent a few days in the field with the writer and did much to familiarize him with the stratigraphy of West Florida. Miss Julia Gardner, also of the United States Geological Survey, very kindly furnished a collection of data on the status of the Alum Bluff group. Messrs. N. B. Davis and Dan Dahle, Assistant State Chemists, made the analyses of the various samples submitted and the results of their painstaking work adds much to the value of the report. Mr. H. A. Hall, Testing Engineer of the State Road Department at Gainesville, kindly permitted the use of many. analyses from his files. The owners and foremen of the many limestone pits were all exceedingly courteous, interested in the work of this department and were of much assistance. 


\section{CLASSIFICATION OF ROCKS}

In common tie, the term "rock" reiers to something hard and firm, but geologically it is applied to all solid material of which the earth is composed. whether hard and compact. as granite: soft and yielding, as clay: or unconsolidated, as loose sand. The rocks which make up the earth's crust may be divided into three classes: igneous, metamorphic and sedimentary.

Igncous rocks are those which have solidified from a molten mass at or near the earth's surface. Examples of this class are: granite, gabbro and basalt. These are the primitive rocks and from them the other two classes have been formed.

Mctamorphic rocks are those in which the texture and mineral composition of the original rock, either igneous or sedimentary, has been altered by heat. presure or chemical agency or, as is usually the case, by a combination of these. To this class belong gneiss, schist, quartzite and marble.

Scdincutary rocks are composed of the fragments or materials of older rocks, of any class, that have undergone disintegration on the earth's surface, and have been deposited either on land or in water by mechanical, organic or chemical agency, or any combination of these. Rocks of this class can be seen forming today in lakes, streams or in the ocean, just as they have in past geologic times. Examples of these are limestones, sandistones, clays and marls.

All known rocks may be accounted for in the above classification. The seclimentaries cover much more of the earth's surface than the igneous and metamorphic, but. considering the total amount present in the earth, the rocks of sedimentary origin constitute a very small proportion. The earth was entirely composed of igneous rocks before erosion and deposition began and theoretically might be said to consist of a sphere of igneous rocks with a thin outer shell of sedimentaries. The sedimentary rocks occur, as would be expected. only as an outer coating on the earth's surface, though in some areas their aggregate thickness is known to be many thousands of feet.

Much of the land surface is covered by loose material, such as sand, clay, soil or a mixture of all three, the alteration products; beneath this surficial mantle lie the more compact and less weathered rocks. Igneous rocks occur in irregular masses of varying size and shape, whereas sedi- 
mentary rocks lie in beds more or less horizontal at the time of deposition, but often tilted, folded and crumpled by subsequent earth movements. All rocks found in Florida belong to this sedimentary group, and of these only limestones and marls will be considered in this report.

\section{LIMESTONE}

Chemically pure lime is the oxide of calcium (CaO), and is widely distributed throughout the earth's crust; it is present in almost all rocks, igneous, metamorphic and sedimentary, though some of these carry it in very small quantities. Chemically it is rather active and therefore is not found native but always in combination with other substances, chief among which is the gas, carbon dioxide ( $\mathrm{CO}: 2)$, forming calcium carbonate $(\mathrm{CaCO}:$ ), the principal component of limestone, the mineral calcite, clam, oyster and other marine and fresh-water shells. Pure lime is not readily soluble in water but is soluble in water charged with $\mathrm{CO}_{2}, i$. c., carbonic acid, after the formula :

$\underset{\text { water }}{\mathrm{H}_{2} \mathrm{O}}+\underset{\begin{array}{c}\text { carbon } \\ \text { dioxide }\end{array}}{\mathrm{CO}_{2}}=\frac{\begin{array}{l}\mathrm{H}_{2} \mathrm{CO}_{3} \\ \text { carbonic } \\ \text { acid }\end{array}}{\mathrm{C}^{2}}$

Rainwater absorbs $\mathrm{CO}$ : from the atmosphere and forms carbonic acid, or water coming in contact with decaying vegetable matter in the soil forms carbonic acid. Thus, water percolating through the soil is charged with $\mathrm{CO}_{2}$ and when this acilulated water encounters the calcium carbonate it takes it into solution as calcium bicarbonate in accordance with the following:

$\underset{\begin{array}{c}\mathrm{H}_{2} \mathrm{CO}_{3} \\ \text { acid }\end{array}}{\text { acic }}+\underset{\begin{array}{c}\text { calcium } \\ \text { carbonate }\end{array}}{\mathrm{CaCO}_{3}}=\underset{\begin{array}{c}\mathrm{CaH}_{2}\left(\mathrm{CO}_{3}\right)_{2} \\ \text { calcium }\end{array}}{\text { bicarbonate }}$

Still in solution the lime is delivered by streams and rivers to the ocean where it finds conditions favorable for deposition.

This deposition of the $\mathrm{CaCO}: 3$ to form limestone is brought about through two main processes: First, through the activity of organisms that cause the precipitation of calcium carbonate $\left(\mathrm{CaCO}_{3}\right)$ in contact with their soft tissues, $i$. c., the lime-secreting organisms. Second, through chemical precipitation by either organic or inorganic agencies that lead to the supersaturation of water with reference to calcium carbonate $\left(\mathrm{CaCO}_{3}\right)$. 
A large portion of the linestone deposits were probably formed in the first manner, namely, by the secretions of living organisms: molluscs, foraminifera, conals, etc. As these different organisms have died their shells, practically pure $\mathrm{CaCO}$, have been deposited on the sea floor in the bed of limestone then forming. By current and wave action most of these shells have been broken into fragments before reaching their final resting place, so that no trace of their original form is left; but some have been laid down in quiet waters and there formed the shell limestones, beds made up almost entirely of well preserved fossils. Lime-secreting alge are also important in this organic formation of limestones, but seldom is the structure of the seaweed preserved in the rock formed. Thus alga no doubt contribute greatly to the amorphous lime matter that fills the voids in coral reefs or between fossil forms.

Through the second process, that of chemical precipitation, much limestone has been formed, and is being formed today in the shallow tropical sea around southern Florida and the Bahamas. There are several methods of chemical precipitation that are all active in the formation of such cleposits, but just what part each plays and how much limestone is formed by each cannot be determined. It is obviously impossible to determine the exact method of formation of any given part of a limestone, but the different methods of chemical precipitation discussed below are all actively contributing factors.

(a) Precipitation through contact with other chemical compounds. The streams that carry lime to the sea take up large amounts in solution until they are completely saturated, no longer have an excess of $\mathrm{CO} 2$ and therefore no further solvent action on limestone. When such a stream empties into the sea, the stream water takes into solution some chloride and sulphate salts present in sea water which are much more soluble than calcium carlonate ( $\mathrm{CaCO}:$ ) and therefore some lime is precipitated, but the water is still saturated with the carbonate and bicarbonate of calcium.

(b) Precipitation of calcium carbonate ( $\left.\mathrm{CaCO}_{3}\right)$ from the sea by the sun's heat. The sea waters around southern Florida are constantly receiving large amounts of the carbonate and bicarbonate of calcium ancl are saturated. Any means whereby the $\mathrm{CO} z$ can be driven off from the sea water will leave a stpersaturated solution and will precipitate calcium carbonate $\left(\mathrm{CaCO}_{3}\right)$. This may be done by the sun's heat, for 
it takes only a slight rise in the temperature of the sea water to liberate the $\mathrm{CO}_{2}$ - a violent agitation of the water may help in releasing it and result in precipitating calcium carbonate ( $\left.\mathrm{CaCO}_{3}\right)$. The sun may also accomplish this same end through the evaporation of sea water. again, though in a slightly different manner, bringing about supersaturation with reference to calcium carbonate $(\mathrm{CaCO} s)$ and the resulting precipitation. This evaporation need only be comparatively slight, for calcium carbonate is quite insoluble and is the first precipitate from a supersaturated solution of sea water. Should evaporation continue to any great degree, as in the cut-off arm of a sea in an aricl climate, rock salt $(\mathrm{NaCl})$ and gypsum $\left(\mathrm{CaSO}_{4}\right)$ in particular and other mineral salts which are far more plentiful in sea water than $\mathrm{CaCO}$ s would be deposited in such quantities that the $\mathrm{CaCO}$; would be completely masked.

(c) Precipitation of calcium carbonate ( $\mathrm{CaCO}:$ ) through the action of bacteria. Working in the Tortugas Laboratories in 1910-12 the late G. H. Drew found that there were present in the sea around southern Florida and the Bahamas, great numbers of bacteria capalble of converting the nitrates of sea water into nitrites and thence into ammonia.* It has been known for a long time that the addition of a strong alkali, as ammonia, to sea water would produce the precipitation of the carbonate of lime so that the presence of such organisms accounted in part for the chalky muds found forming off the Florida Keys and the Bahamas. The latest work clone on this problem is by N. R. Smith, of the U. S. Bureau of Plant Industry. $\dagger$ In studying samples of the bottom muds around the Bahamas he discovered that there were present, in addition to the denitrifying bacteria, ammonifying bacteria which were more active in the precipitation of $\mathrm{CaCO}$. These latter thrive on the organic matter in the bottom muds and in their growth produce $\mathrm{CaCO}$ s from calcium sulphate $\left(\mathrm{CaSO}_{4}\right)$ under conditions where the denitrifying bacteria will not, viz: in the absence of the nitrates. It has been contended that denitrification will not take place in pure sea water. This may be true of the upper layers of the sea, but the bacteria are bottom-living organisms and the organic matter in the bottom muds acts as a nutrient. Just

*G. H. Drew-On the precipitation of calcium carbonate in the sea by marine bacteria and on the action of denitrifying bacteria in tropical and temperate seas. Carnegie Institution of Washington, Pub. 182, 1914.

$\dagger T$. Wayland Vaughan, "Present status of studies on the causes of the precipitation of the finely divided calcium carbonate." In Report of the Committee on Sedimentation-issued by National Research Council, Washington, D. C., 1924. 
how large a part these bacteria play in the formation of calcium carbonate $(\mathrm{CaCO}:)$ in the chalky oozes or muds seen forming off certain islands around southern Florida or what part they may have played in the formation of the chalky limestones of other geologic ages is not known, but that they are a contuibuting factor to the formation of limestone is beyond doubt.

Green plants which use considerable amounts of $\mathrm{CO} 2$ will also bring about the precipitation of $\mathrm{CaCO}$; from a supersaturated solution. The sea plants use $\mathrm{CO} 2$ for food just as land plants do, but they must derive it from the sea water: the withdrawal of the $\mathrm{CO}_{2}$ from solution brings about a natural concentration and the precipitation of $\mathrm{CaCO}_{3}$ so released.

In an idleal case with all the methods enumerated above functioning, the sea floor will be covered with more or less worn and broken shells, and shell fragments, the remains of lime-secreting alge and a soft oozelike mass of calcium carbonate sent down through the different chemical precipitations. This amorphous mass of finely divided particles of $\mathrm{CaCO}$ : acts as a cement for the unconsolidated beds of shells or shell fragments and tends to bind them together. Should the sea floor sink and this bed be buried under newer sediments the increased pressure causes further consolidation, as limestone will readily go into partial crystallization under these conditions. On the other hand, should the floor of the ocean rise and expose the bed, rain water will leach out the $\mathrm{CaCO} 3$ from the upper layers and redeposit it in the lower, and water percolating through the body of soft rock will cause the $\mathrm{CaCO}$ s to partially crystallize, thus again through semicrystallization bringing about further consolidation. The degree of consolidation has much to do with classifying limestones according to their texture, as can be seen from the following types of limestones. The term "limestone" includes rocks differing widlely in color, composition, structure, hardness and texture. The one property common to all is that of consisting chiefly of the mineral calcite, $\mathrm{CaCO}:$. 


\section{VARIETIES OF LIMESTONE FOUND IN FLORIDA \\ BASED ON PHYSICAL CHARACTERISTICS}

Semicrystalline limestonc-A hard, rather compact limestone originally soft and dense, but recrystallized by the action of water. Frequently this recrystallization has taken place about a fossil mass; sometimes the recrystallization is so complete that no original structure is left and the resulting material is very hard, uniform and brittle. Many examples of partial crystallinity are found in all limestone formations of Florida that have been exposed to weathering or through which ground water has percolated.

Fossilifcrous limestonc-Any limestone in which fossil shells or other animal remains, such as bones, teeth, etc., are prominent. All Floricla limestones are fossiliferous in varying degrees.

Shell lincstone-A limestone composed almost entirely of shells or shell fragments. Parts of the Ocala are excellent examples of this type, and also some of the younger formations. The coquina is of course a classic example.

Chalky limestone-Partly consolidated limestone composed of microscopic shells. The Marianna limestone is mostly of this type.

Colitic limestone-Limestone made up of tiny nodules or concretions of $\mathrm{CaCO}$, resembling the roe of fish. Miami and Key West limestones.

Sandy limestone-A linestone which has been deposited near the shore with the result that the currents have carried in much sandy material which has been incorporated in the main body of the limestone. Northern parts of the Miami oolite, and parts of the Alum Bluff formation.

Cherty or Flinty limestonc-Limestone containing nodules or bancls of chert or "flint." Chert is composed of silica ( $\mathrm{SiO}_{2}$ ), and the nodules have been segregated within the limestone. It is probably of seconclary origin, formed by the action of ground water from the spicules of silicasecreting sponges and other siliceous matter scattered throughout the deposit.

Marl-A somewhat indefinite or elastic term, but might be defined as a soft earthy mass macle up of variable quantities of lime, clay, sand and carbonaceous material. Part of the lime content is often in the 
form of shells or shell fragments. Marl may be either of fresh-water or marine origin and is designated accordingly.

\section{BASHD ON CHEMICAL COMPOSITION}

Hish-Calcium limestont-A limestone which contains little or no magnesium carbonate ( $\mathrm{MgCO}:$ ), and very little of impurities as iron, silica and alumina. It generally carries $93 \%-99 \%$ or more $\mathrm{CaCO}$.

Magncsian limestone-A limestone containing variable percentages of magnesim carbonate $(\mathrm{MgCO}: 3)$, up to the theoretical percentage for a clolomite. (See below.)

Dolomite-A mineral composed of the double carbonate of magnesium and calcium, ( $\mathrm{g} g \mathrm{CO}: \mathrm{CaCO}:$ ). It contains $54.35 \% \mathrm{CaCO} 3$ and $4.5 .6 .5 \% \mathrm{MgCO}: 3:$ :

Arcnaccous and Silicens limcstone-Siliceous limestones are those which contain silica in any of its several forms: it may be present as the spicules of sponges or as other organic forms or as sand grains. In the latter case it is called "arenaceous" and is the same as "sandy limestone."

Argillaccous limestonc-A limestone which contains much clayey material, as iron, alumina and finely divided silica. Like "sandy limestone," it is formed near the shore where the currents have brought in impurities to the limestone deposit there forming.

All the Floricla limestones, with the exception of the argillaceous Chattahoochee, are high-calcium limestones. The weathered surface of these may contain a varying percentage of magnesium, but the fresh material probably will not carry more than $3 / 4-1 \% 2 \%$. Chert and flint boulders occur on the weathered surfaces of almost all the Florida limestones, but are much more abundant in the Ocala than in any other formation.

\section{USES OF LIMESTONE AND LIME}

The uses of limestone and the commercial preparations derived from it are too numerous and varied to receive any extended treatment here, but a short list of the more important applications of this great natural resource may not be out of place.

*Dana, E. S., A textbook of mineralogy, p. 358. John Wiley \& Sons, N. Y., 1900. 


\section{RAW LIMESTONE}

Road Material-Crushed limestone is extensively used in road construction, both as a base and as surfacing material. In Florida, where soft limestones are very abundant and harder limestone somewhat rare, the common practice is to construct the foundation of soft pure limestone finely ground so that when it is dampened and rolled it will set in a hard uniform mass, leaving the minimum number of voids. This base is then treated with oil and a hard surface put on. The surface may be of several kinds-asphalt, penetration or hard limestone. Experience has shown that an unsurfaced soft limestone road or even one

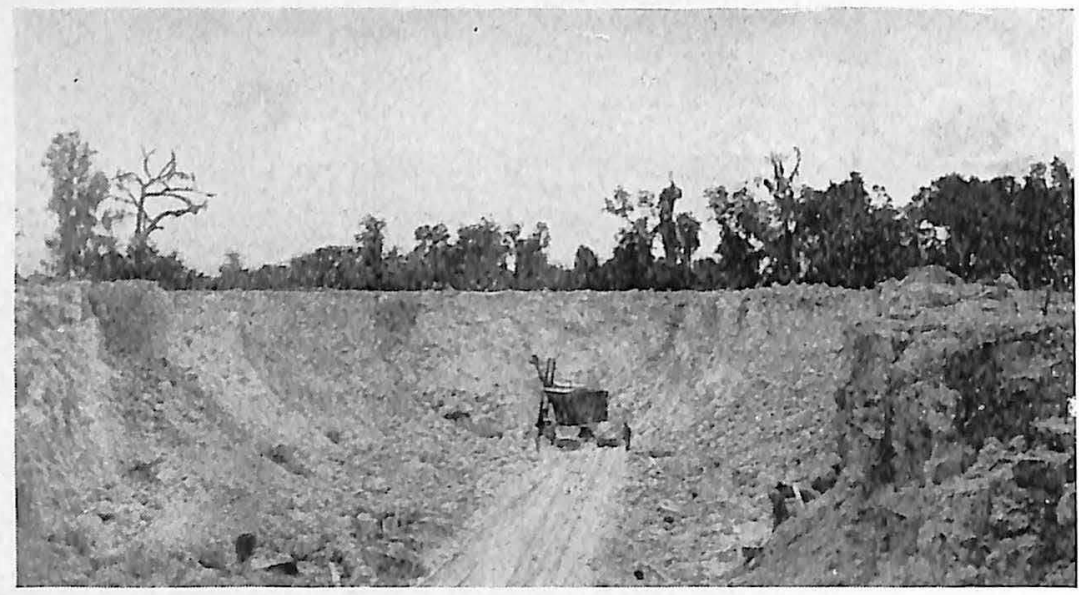

Fig. 3.-Ocala limestone. Pit of Connell \& Schultz, near Pineola, Citrus County.

surfaced with hard limestone alone will stand up under ordinary traffic reasonably well for a limited time, but after that will disintegrate rapidly. Maintenance costs are high and the practice not satisfactory, for hollows and ruts started by traffic are enlarged by rainfall and wash and then hardened; if these worn places are patched with either soft or hard limestone the newly laid material has no chance to cement and is soon worn away, leaving the road in as bad condition as ever. The better practice is to use a comparatively waterproof surface; the penetration type has generally been found to be most satisfactory for heavily travelled roads. In this type of surfacing hard rolled limestone or slag 
is used, sandwiched between bituminous binders, to cap the soft limestone base.

Concrete Aggregate-Limestone is much used as a coarse aggregate for concrete work; the size of the material depends naturally on the character of work in which the material is to be used. Usually the rock is graded from material that will pass a two and one-half-inch mesh to that which will rest on a one-half inch. The requirements of such a rock are that it be hard, tough and of a good crushing strength. There are many deposits of limestone in Florida that meet the requirements; flint is also used in many sections.

Railroad Ballast-For railroad ballasting a stone must have a high crushing strength and must neither dust nor chip easily. Several different Florida limestones have proven quite adaptable for this purpose, even though they may not come up to the highest desirable specifications in every case. The Miami oolite from Ojus, the Key Largo limestone, Glendon limestone from Lyle quarry north of Live Oak, the Ocala rock from Crystal River and the Tampa limestone from Brooksville have all

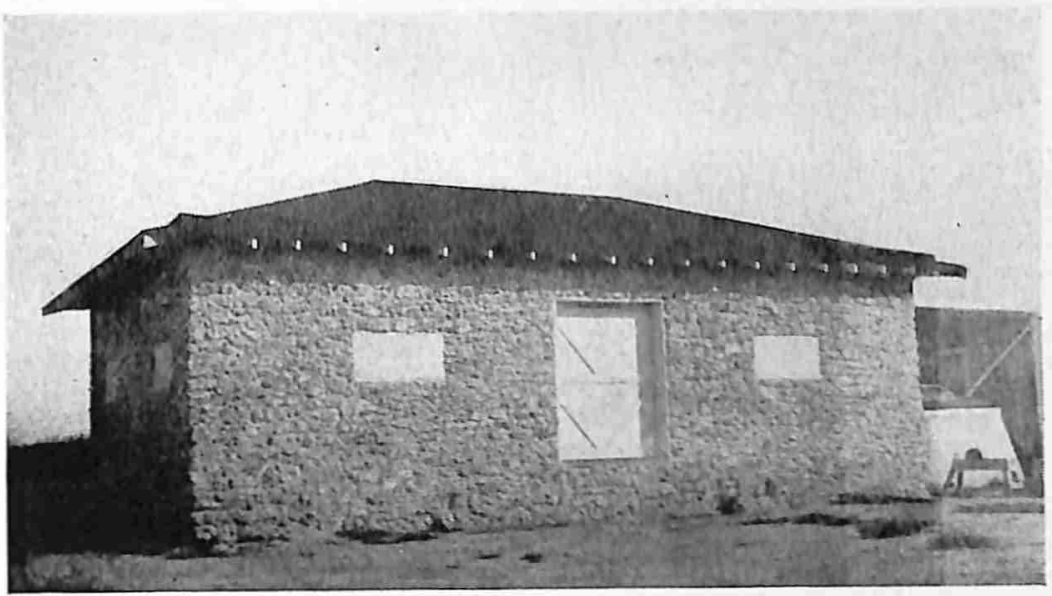

Fig. 4.- House built of Key Largo limestone. Islamorada, Monroe County.

been successfully employed for this purpose. In general any concrete rock will do for ballasting, but the converse is not true; oftentimes a rock that will not quite meet the requirements for a concrete aggregate can be used in railroad ballast. 
Building Stone-The Florida limestones as a class do not possess the hardness and crushing strength of the older formations that occur in the more northern States and are famous for their adaptability as a building stone. Nevertheless considerable use has been made of the native rock in this State, though this use has in most instances been restricted to small farm buildings and outhouses. Notable exceptions to this generalization are the old Spanish fort at St. Augustine, constructed of coquina; modern bungalows all along the East Coast made of the same material; and the beautiful homes in and near Miami built with the Miami oolite. Limestone from this last-named formation has in recent years been employed on an increasing scale in construction work locally; the court house in Miami, Halcyon Hall hotel, the buildings on the Charles Deering estate and scores of other fine homes as well as foundations, sea walls, etc., are built of this native limestone.

The Marianna limestone and, in some localities, the Ocala, are quarried on a small scale and cut into building blocks used locally in different building uses, especially as house supports and in chimneys for frame houses. Throughout other areas the weathered boulders of the different limestone formations are used with cement in building rough foundations or in building small rock cottages where a rustic appearance is

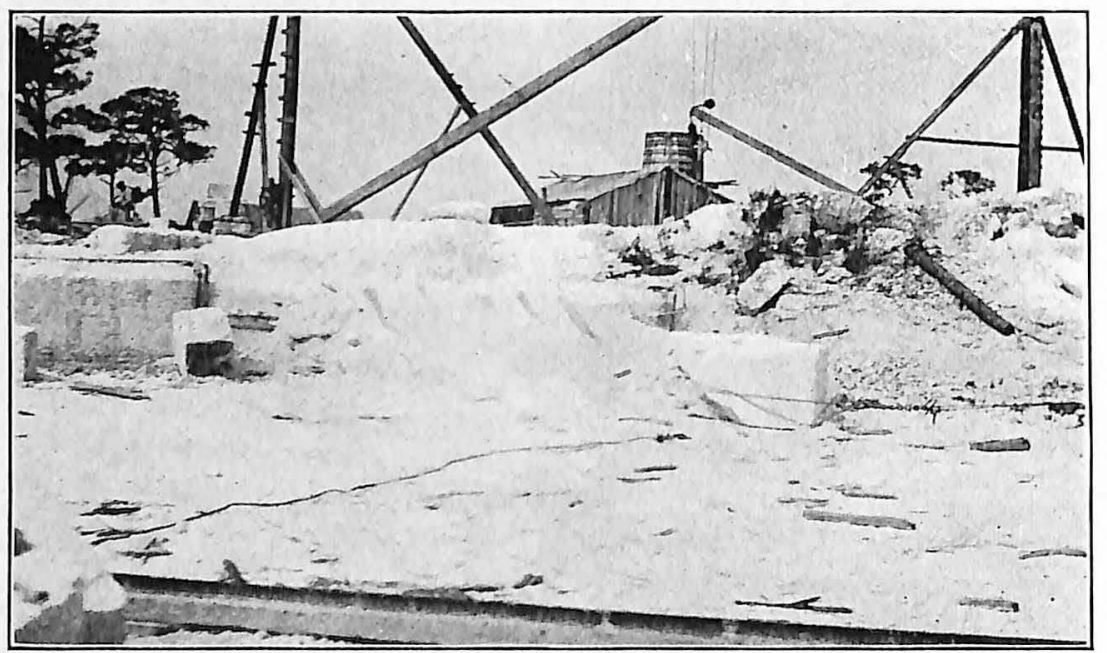

Fig. 5.-Quarrying the Miami oolite for building stone near Miami, Dade County. 


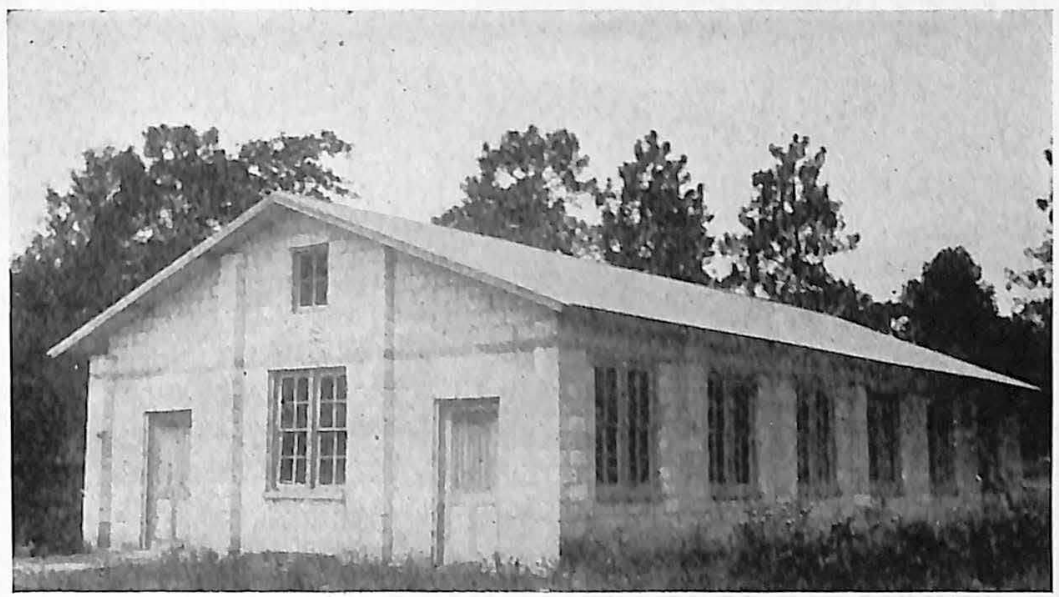

Fig. 6.-Building constructed of blocks sawed from Marianna limestone. Marianna, Jackson County.

desired. Limestones of the Glendon and Tampa formations are in many places hard and durable enough for building purposes, but the limestone occurs in too irregular lenses or masses to make a good building stone, and these often are not homogeneous but contain many small voids due to solution or fossil impressions.

\section{CEMENT $\cdot \mathrm{MAKING}$}

Portland cement is the product obtained by burning to the point of incipient vitrification a mixture of silica, calcium carbonate, alumina and iron oxide, and grinding the clinker to a powder. The various elements are present in the raw material in certain definite quantities, so that the mixture is nearly always an artificial one; seldom is a limestone found that carries the various impurities in the proper proportions. The principal ingredients are limestone and clay or very pure limestone and argillaceous limestone. The Florida limestones are very pure (93-99\% $\mathrm{CaCO}_{3}$ ) and are widely spread, large and easily worked deposits; they are very low in magnesium carbonate, which further adds to their desirability as the principal ingredient in cement.

AGRICUL'TURAL LIMESTONE AND LIME

Modern scientific farming has brought about the use of lime as a fertilizer. It has been found that the application of lime, either in the 
form of raw limestone $\left(\mathrm{CaCO}_{3}\right)$, hydrated lime $\left(\mathrm{Ca}\left(\mathrm{OH}_{2}\right)\right.$, or quicklime $(\mathrm{CaO})$, will neutralize the acid content in certain "sour" soils and be beneficial to a great number of crops; but there is much controversy as to just which form of lime is best. Agricultural lime as produced in Florida, at or about Ocala, and shipped throughout northern Florida and southern Georgia, is made by simply grinding or reducing the soft Ocala limestone to a powder.

\section{QUICKLIME AND HYDRATED LIME}

Pure limestone is expressed chemically by the formula $\mathrm{CaCO}_{3}$; when this is heated to a temperature of about $900^{\circ} \mathrm{C}$. the gas, carbon

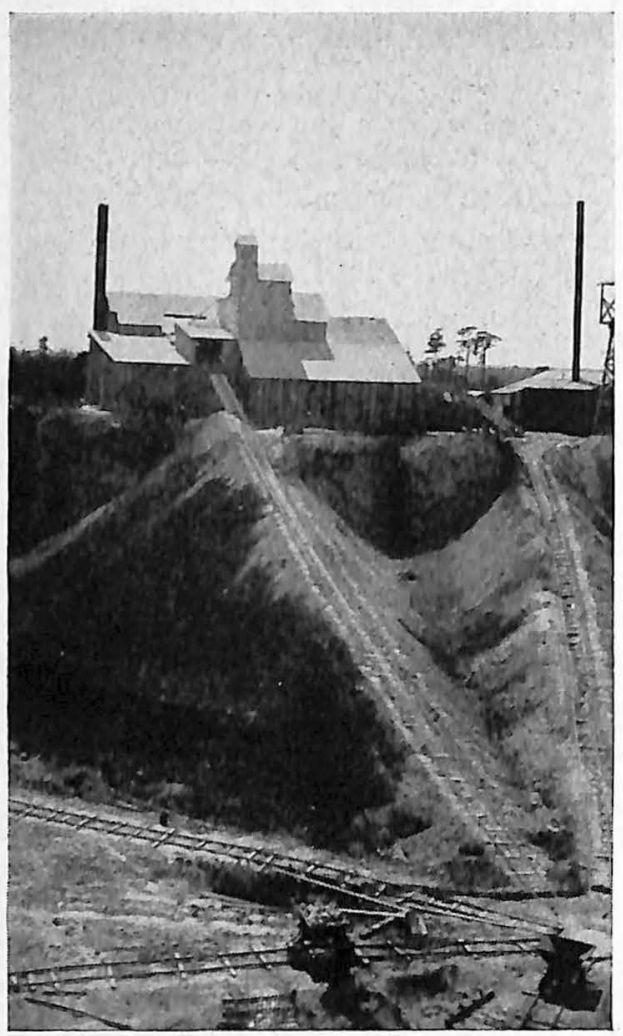

Fig. 7.-Hydrating plant and limestone pit of Florida Lime Company, Zuber, Marion County. 
dioxide $\left(\mathrm{CO}_{2}\right)$, is Iriven off, leaving pure lime $(\mathrm{CaO})$, known commercially as lump lime or quicklime. If this material is allowed to remain exposed to the air for a sufficient length of time, it will crumble to a powder, owing to the absorption of moisture or water from the atmosphere by the lime to form calcium hydroxide $(\mathrm{Ca}(\mathrm{OH}) 2$-airslaked or hydrated lime. This same process is more quickly accomplished by addling water to the lime as is done when slaking lime to make building mortar. Lump lime has long been manufactured, chiefly for use in the building trades. In the last ten to fifteen years hydrated lime has come into increasing importance, because there are many industries that use the lime in hydrated form and this hydrating can be more accurately clone by hydrators at the lime plant, thus eliminating inconvenience and the risk of over or under-burning in the slaking by unskilled workman. The various uses of lime are too well known to do more than list them-plaster, mortar, agricultural purposes and with Portland cement to make a more plastic mortar or a hard, smooth finishing material, as well as other uses.

Sand-Lime Brick-Sand-lime brick have been on the market for less than twenty-five years and in the last ten have shown an increasing importance, due to refined methods and the better quality of the finished product, that bids fair to make it a larger factor in future construction work. This brick consists essentially of a mixture of lime and sand molded to brick form and then subjected to steam pressure which increases the cementing power of the lime.

\section{CHEMICAL LIME}

The chemical and inclustrial uses of lime, either in the form of raw limestone, quicklime or hydrated lime are almost without limit and probably no list includes all of them. Below are given some of the more important and better known uses:

Glass-In the manufacture of glass-window, plate, bottle, etc.lime is a very necessary constituent, for glass is composed, in the main, of the silicates of sodium and calcium. The lime is generally introduced in the form of pure high-calcium limestone and forms from $10 \%$ to $25 \%$ of the mixture, depending on the variety of glass. In some types of glass, quicklime and hydrated lime are used to avoid giving off a gas at high temperatures. 
Limclight-If a strong flame of intense heat is played on a stick or small block of lime a dazzling white light is obtained. This type of light is used in the spotlights of theatres and also in lighthouses and the searchlights of vessels.

Water softening-A "hard" water is one in which calcium carbonate $(\mathrm{CaCO}:)$ is held in solution by excess carbon dioxicle $(\mathrm{CO} 2)$. Any' means whereby this $\mathrm{CO}:$ can be removed will precipitate the $\mathrm{CaCO}$ :. which is quite insoluble; commercially this is done by adding hydrated lime $(\mathrm{Ca}(\mathrm{OH})$ 2. The $\mathrm{CaO}$ of this alded mixture combines with the excess $\mathrm{CO}_{2}$ in the water to form $\mathrm{CaCO}$, which together with the insoluble $\mathrm{CaCO}$ : present is removed from solution.

Blcaching poa'der-Lime enters into the manufacture of blcaching powder, known as chloride of lime, as it does into many other processen in industrial chemistry because it is the cheapest base available: the product is manufactured by passing chlorine gas over slaked or hydrated lime, which has considerable absorbing power. 'The product is used as a disinfectant, oxidizing agent, and in bleaching cotton fabrics.

Coramics-Limestone, or in some cases, the oxicle and hyclrate of lime, is used to a small degree in the mantufacture of pottery and porcelain. The use of the lime is as a flux, for it has been found that in wares burned at moderate temperature the lime tends to bring the point of vitrification and fusion nearer together; magnesia has been found to be a more desirable base than calcium however. When the ware is burned at a high temperature the gases given off by the decomposing carbonates are undesirable and so in this type of product the oxide or hydrate is used. Into glazing processes lime sometimes enter; to absorb some of the sulphurous kiln gases, though magnesia again seems to give better results.

Calcium carbide, which is the source of acetylene, a gas widely used for illuminating and high-temperature flames, is made by fusing coke and lime in an electric furnace.

Illuminating gas and ammonia-Ordinary illuminating gas is made by the distillation of coal; the gas thus produced is passed through water, which removes the ammonia and ammonia compounds; this solution is then treated with line to break up the compounds, heated and the gaseons ammonia is triven off and collected. The illuminating gas that has passed through the water contains many inpurities, as carbon 
dioxide and hyrlrogen sulphide, therefore this gas is passed through slaked lime and the objectional gases removed.

Sugar refining-The juices extracted either from the sugar beet or sugar cane contain impurities that would discolor the protuct or turn some of it into an uncrystallizable glucose: therefore thesa juices are heated almost to boiling in the presence of lime. This rencts with the acids, breaks up organic compounds and forms varions insoluble salts which can be removed : unfortunately it also forms an insoluble salt with the sugar itself, so that this must be treated with $\mathrm{C}($ )., which breaks up the lime-sugar compound, and combines with the lime to form calcium carbonate, which is precipitated. leaving the fine crystalline sugar.

Tanning-Hicles are soaked in lime water to loosen the hair, which can then easily be removed by scraping.

Clycerinc, lubricants, soaps, itc.-In the manufacture of materials: of this class lime is quite important, for by means of it the fatty compounds can be broken up. Glycerine is liberated when the fats are distilled with lime in water: the line "soaps" left by this process are mixel with the heavy mineral oils and solk as lubricants, or else the residue can be treated with sulphuric acid and the separated fatty acids user in manufacturing soap. candles and other products of this class. Other industrial uses of chemical lime are: Paint manufacture: distillation of wood to produce wood alcohol, acetic ac:d and acetone: manufacture of paper, canstic soda and soda ash: calcium cyanamide and calcium nitrate. of increasing importance as fertilizers: calcium arsenate: as an asphalt filler and filler in the paper, textile and rubler industries: in manufacture of various chemicals; in the metallurgy of iron, steel. mercury, sold. silver, etc, and in many other industrial processes. The Floricla limestones are as a rule exceptionally pure $(9) \cdot 949 \% \mathrm{CaCO}: ;)$, and the (puicklime and hydrated lime made from them is a very fine product adaptable to many of the above industrial uses, but the distance from manufacturing centers has kept then from being used extensively, though some material for chemical use has been shipped as far north as Charleston, S. C., and to points in Alabama and Georgia. Nost of the Florida production goes into road material and other construction uses. 


\section{LIMESTONES OF FLORIDA}

The limestones of the various formations, their distribution, lithology and other characteristics will be considered later in detail uncler their formational names. But it is thought fitting, after the foregoing general remarks on limestone origin and classification, to give here a brief account of the origin, texture and structure of the Florida rocks.

\section{ORIGIN}

The Florida limestones were all laid down in warm tropical waters, mostly marine, at no time deeper than 100 fathoms; it is probable that most of the deposition took place at depths of $25-50$ fathoms. Deposition usually took place on a sinking sea-floor, which accounts for the thicknesses of the Eocene and Oligocene formations, but the seas in which these deposits were formed were all shallow. During Pliocene and fieistocene time some of the deposits were formel in brackish and fresh water of very shallow depth-50 feet or so-but the deposits so formed are of no great extent. The periods of cleposition were closed by the emergence or partial emergence of the sea-floor; erosional agencies set to work and a new formation began to be laid down. The crustal warpings or deformations which caused the rising and sinking of the sea bottom have been due to compressional forces acting at right angles to the axis of the peninsula; these deformations have been comparatively slight and gentle, and, since they have acted over such a large area, they have had little local effect on changing the character of the limestones. The deformations of the Florida land mass have not always acted uniformly over the entire region-often the movement lias been clifferentia! -so that an arm of the sea from the Gulf side might cover one part of the peninsula, while at the same time another part might be under the waters from the Atlantic side. Because of this, some formations with different names in the Florida section are considered contemporaneons. This is especially true of many of the shallow water limestones and marls of the Pleistocene.

The ideal condition for limestone deposition is a rather quiet, shallow, clear, tropical sea, rich in dentrifying and ammonifying bacteria and lime-secreting organisms, and receiving much $\mathrm{CaCO}$; in the run-off from the chemical denudation of the surrounding well-wooded lands.

Conditions in southern Florida today are in general much like those prevailing over this whole region in past geologic time, and it can be seen that here these ideal conditions are largely realized. There is much limestone on the land; waters become charged with $\mathrm{CO}$ passing 
over the large areas of decaying vegetable matter; because of the gentle slope of the land, these waters are long enough in contact with the limestone to take the $\mathrm{CaCO}$ : into solution and then carry it on to the ocean. Vaughan' suggests that in proportion to estimates made in other parts of the world, the amount of such material poured anmually into the bays and sounds of southeastern Florida may be between $4,000,000$ and $5,000,000$ tons. Thus we can see that the waters surrounding southern Floricla are receiving large quantities of lime, just as in the past the warm waters covering all parts of the present Florida received lime from land masses to the north, west and southwest.

It is very likely that the accumulation of lime in the older seas was slower than in those of today, because the source of lime was farther removed and these older formations probably did not yield their lime as readily or copiously as do the softer, purer deposits of the presem Florida. From solution in the ocean the limestone has been precipitated and deposited on the ocean floor. 'This precipitation has taken place both chemically and through the action of organisms : bacteria, which by their physiological processes, produce ammonia, which acts on the calcium sulphate $\left(\mathrm{CaSO}_{4}\right)$, a salt present in large quantities in sea water, and forms $\mathrm{CaCO}:$; lime-secreting algre are also especially abundant in the warmer waters; corals, foraminifera, molluses and other lime-using organisms have contributed quite considerably to the deposits, and much of the $\mathrm{CaCO}$ : derived in this way is in the form of finely comminuted shell fragments: in the quiet shallow-water deposits the larger organisms have remained intact or in large fragments. Examples of this can be seen in any of the shell marls, and indeed all Florida limestones are very rich in these well-preserved fossil shells, but only in the deposits formed in rather quiet, shallow water are they found in such quantitic; as to make up the main body of the bed. Evaporation of sea water saturated with $\mathrm{CaCO}$; ; heating by the sun thus driving off $\mathrm{CO}_{2}$; green plants that use $\mathrm{CO}_{2}$, and partial chemical rearrangement whereby streams laden with $\mathrm{CaCO}$; from the land drop some of their chemical load to take up more soluble salts which they encounter in the oceanall of these play their part in the formation of the Florida deposits.

\section{THXTURE}

The term texture applies to the arrangement, size and shape of the constituent particles of a rock.

'T. Wayland Vaughan: $A$ contribution to the geologic history of the Floridian Plateau, Carnegie Institution of Washington. Pub. 133, p. 135, 1910. 
A limestone rock is made up of grains of limestone ( $\mathrm{CaCO} 3)$ and, depending on the size of these, may be fine, medium or coarse grained. When the grains are of microscopic size the rock is said to be "dense"; if the grains can be seen with the naked eye, the term "grantlar" is used. As has been previously mentioned, the degree of consolidation greatly influences the texture. Deposits of marl newly formed are unconsolidated, porous and exhibit "earthy" texture; should they be a little further consolidated, though still porous, they are called "friable." The degree of porosity depends on the size of the interstices; if large, the rock is "coarsely porous"; if small, "finely porous." Limestone made up of shells, corals and other animal remains more or less broken up by the erosional agencies which have assembled them, are called "frag-

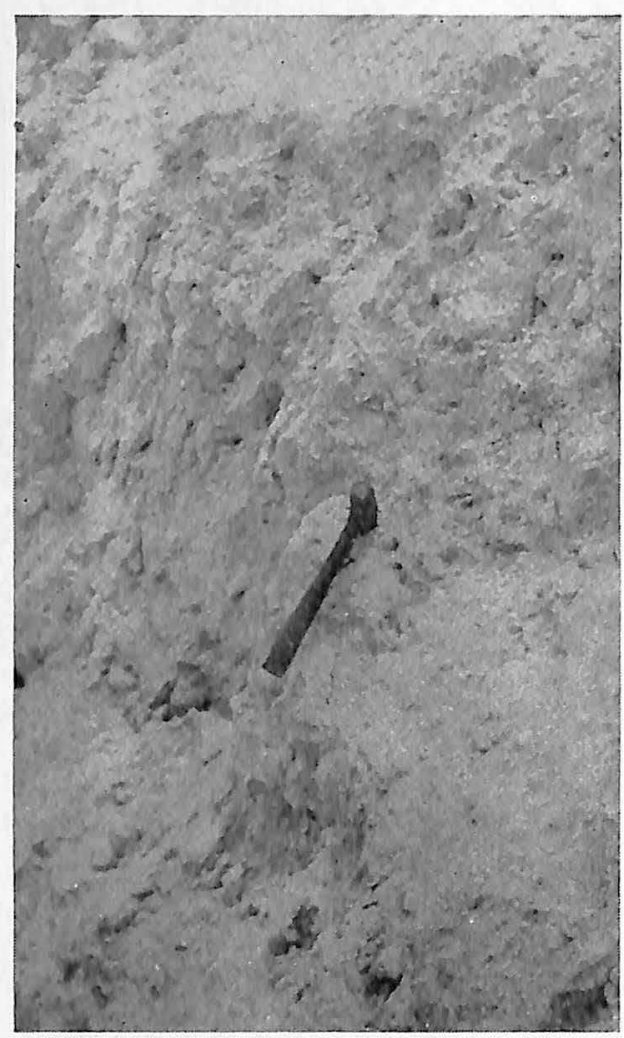

Fig. 8.-Near view of Ocala limestone in Connell \& Schultz pit, near Pineola, Citrus County. 
mental"; should the different particles be bound together by crystals of calcite, the texture is "crystalline," the degree of crystallinity depending on the completeness of the crystallization. If the rock is without form or exhibits no crystallinity it is "amorphous." Should all the particles, grains, fragments and crystals that make up the rock be more or less uniform the rock is "even-grained"; should there be considerable variation, "uneven-grained." All of the characteristics may be present in one rock, so that it would not be unusual to find a limestone which was "coarsely granular, friable, porous, fragmental and uneven-grained." In fact, the more characteristics that can be recognized in a rock, the better it can be clescribed.

\section{- StruCtURE}

The term "structure" applies to the features of a body of rock or formation as a whole rather than its constituent parts and includes both original and secondary features. Original features are those that a rock has at the time of deposition; secondary features are those which have been acquired subsequently, usually through metamorphic agencies. The limestones of Florida are all of Tertiary and Quaternary age. therefore geologically young, and all lie within the Coastal Plain province, a region of comparatively little crustal disturbance. They have not been affected by metamorphic agencies (chiefly heat and pressure). which have folded, faulted and crystallized the older limestones of the northeastern States, and therefore to a large degree they exhibit original textures and structures, in places altered somewhat by the action of ground water.

If at the time of deposition conditions were continuously uniform for a long time the deposit will show no differences in bedding or stratification, but will have a "massive" structure. If bedding planes can be seen a foot or several feet apart the formation is "thick-bedded"; if the planes are only a few inches apart- "thin-bedded." The thinnest seperable layers or sheets in a stratified rock are called "laminx." These are not often seen in most of Florida limestones but are quite noticeable in the impure limestones and the marls that have undergone secondary cleposition. Sometimes within a formation it will be observed that the bedling planes of particular beds instead of being parallel to the general planes of stratification of the series, or nearly horizontal in Coastal Plain formations, are inclined at considerable angles, changing markedly in short distances and sometimes curved; this structure is known as "cross- 


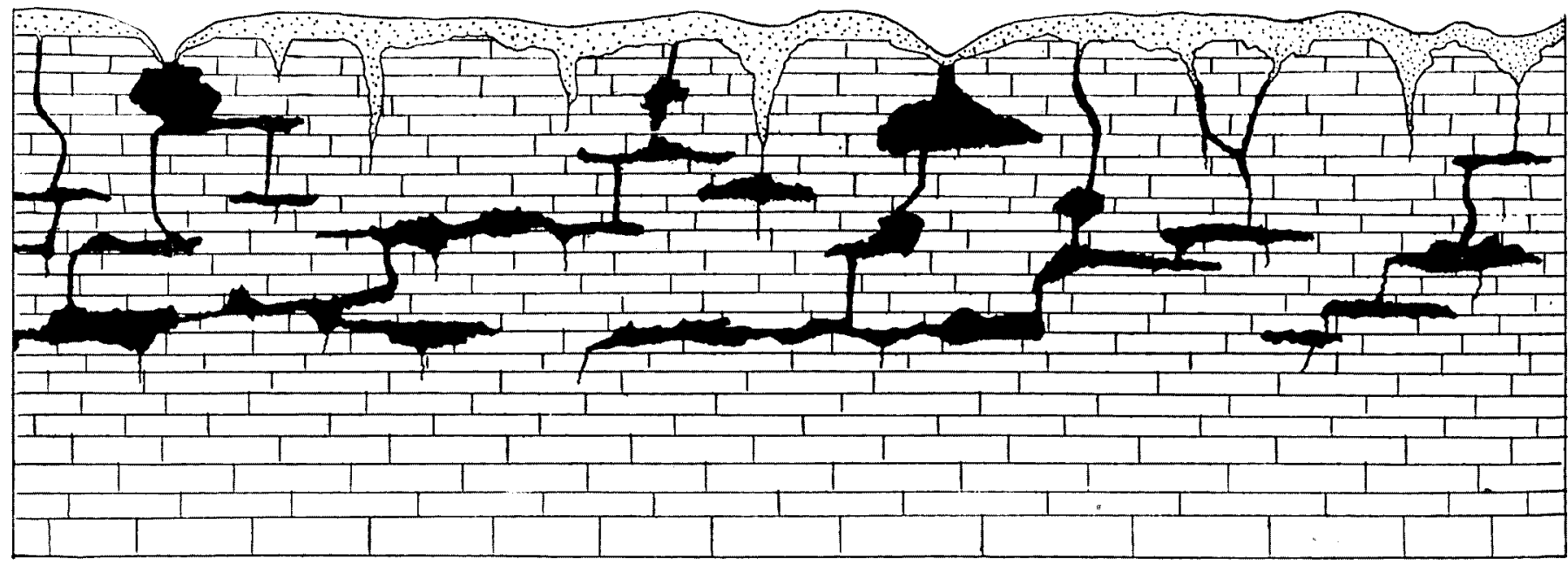

Text Fig. 1.-The above sketch gives some idea of the solution of the soft Florida limestones and illustrates the manner in which sink- $z$ holes, solution cavities, clay pockets, etc., are formed. These underground solution channels are probably not at all as regular and $C$ uniform as here drawn, but on this scale the honeycombed structure and tortuous irregular windings of these caverns cannot be shown to advantage. The solid black represents open cavern spaces, the dotted area the soil mantle of sand and clay. At the left of the sketch $\approx$ can be seen an open sink-hole formed by the falling in of the roof weakened by underground solution; at the right a sink-hole formed $\pi$ in a similar manner but clogged by soil and debris. Solution channels formed by downward percolating waters are shown, many of $\overrightarrow{5}$ these are relatively shallow and filled with sand and clay while others are narrower, open and reach down to the deeper lying caverns. 
bedding." Good examples of this are seen in the upper part of the Miami oolite and in the sandy limestone that forms the backbone of the barrier beach on which Palm Beach is located, particularly well exposed in a road cut through the golf links. Cross-bedding usually indicates deposition in shoal waters by rapid and shifting currents, and is liable to occur in deltas, bars, spits or barrier beaches where the material is dropped on the forward slope of an advancing deposit. "Cross-bedding" is sometimes of æolian origin; no examples of this are found in the limestones as they were formed under water, but this æolian crossbedding can be seen in wind-blown sands that make up the dunes along the East Coast. "Stratification" is the term applied to deposits where the material has been well sorted during deposition. Often in the forming of a limestone bed of any considerable thickness, there have been, from time to time, slight changes in the character of the deposits, so that a limestone formation may have streaks of clayey or sandy material or layers of slightly discolored limestone, each indicating a temporary change in deposition, this is called "banded structure."

\section{WEATHERING}

Water, aided by gases of the atmosphere and a warm temperature, is constantly at work on the limestones, breaking them down into small

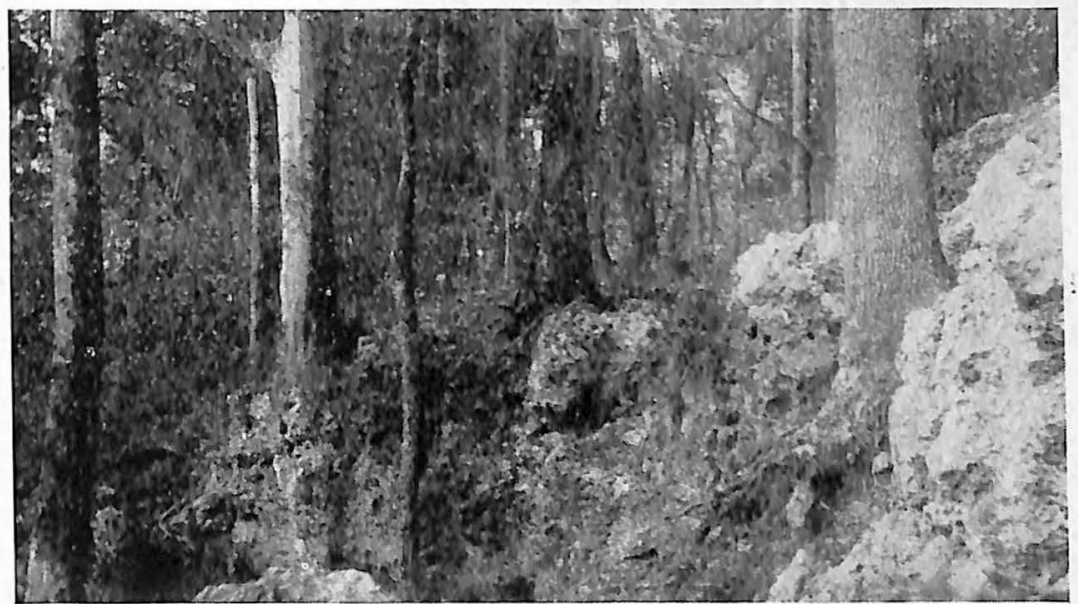

Fig. 9.-Weathered Glendon limestone in sink-hole on Dunn property. Cedar Grove, near Chipley, Washington County. 
particles and removing the $\mathrm{CaCO}:$. This process of distintegration and decomposition by natural agencies is known as "weathering."

Conditions in Florida, both climatic and geologic, favor rapid weathering. Owing to a heavy rainfall there is much water present in the ground; this rainfall, coupled with a warm subtropical climate, has produced luxuriant vegetation and therefore, in turn, an abundance of decaying vegetable matter. The limestones are in general all soft and lying near the surface, as most of them do, are easily accessible to meteoric waters.

The mineral calcite ( $\mathrm{CaCO}_{3}$ ), which is the main constituent of limestone, though not readily soluble in ordinary water, is acted on by water charged with $\mathrm{CO}$; the result of rain water falling through the air or coming in contact with the decaying vegetable matter in the soil, and in this way the $\mathrm{CaCO}$; is removed from the formation. Roots of trees, vines and other forms of vegetation all aid in giving water access to a limestone formation; water will also seep in along planes of weakness. Since the limestones are so soft, the water will find its way through the formation easily enough once it is started in any quantity, so that the hole made by the roots of an overturned tree or the cracks made by the roots of vines will serve to start an extended "pot-hole" or solution channel. On a large scale, in time, a whole formation may be eroded away by this process of weathering, all the $\mathrm{CaCO}$ s being carried off in solution by the ground water and only the insoluble impurities left. In the case of a very pure limestone, a formation 100-200 feet thick may. entirely disappear, leaving only a relatively thin soil mantle of clay and sand-the insoluble impurities of the limestones; should the limestone be more impure the residual mantle will be thicker. If the rock outcrops on a hillside or where there is a slope of considerable grade, there will probably be no mantle present since the material left by the weathering process will have been washed down into a region of lesser slope and there deposited. It is for this reason that limestone is often found at or near the surface on rises and hills while in lower places or valleys the rock is covered with a variably thick mantle of clay and sand. This weathering of the soft limestones, both at the surface and underground, has, in advanced stages, greatly affected the topography and, in the initial stages, produced peculiar and grotesque results.

To explain some of the more common phenomena caused by limetone weathering, let us take a hypothetical case and follow it through. 
Imagine a soft rather pure limestone lying level, exposed at the surface. and supporting a sparse vegetation: as rain water falls on it the $\mathrm{CaCO}:$ is leached out of the upper few inches and redeposited in the lower foot or so because there are no chamels or openings whereby the limeladen waters can escape. This results in an indurated layer of limestone at the surface-such a layer is seldom more than $1-3 \mathrm{ft}$. thick in the Florida rocks: examples of this can be seen in any surface exposed limestone. particularly the Miami oolite and the Ocala limestone. This first surface weathering and releposition is not absolutely uniform and often results in pitted. jagged, uneven surfaces as well shown by the Miami oolite in the pinclands south and west of Miami. Here the rock outcrops at the surface with no soil covering and makes walking extremely difficult: occasionally small debris-filled depressions $3-t$ feet deep are encountered, but for the most part the surface is made up of rough, hard, uneven limestone. As the weathering continues, water finds its way down the cracks made by roots or gathers in hollows formed by overturned trees, and in time dissolves the limestone and reaches grouncl-water level. As the result of this vertical solution, hollows with an inverted cone shape are formed, or, in other cases, merely a small channel extending from the surface to water level. As water passes down these openings it seeps into the main boly of the rock and hardens the adjacent limestone. Often these channels are lined with crystals of calcite and aragonite (pure crystallized $\mathrm{CaCO}$ :) deposited by the descending waters. These hollows and channels later become filled with clay, sand and debris washed in by heary rains and floods. as can be scen in exposures in almost any of the lime pits. In some localities there may be only a few of these "pot holes," ranging up to 10 or $: 0$ feet in diameter in an area of several hundred square yards: while in others an equal area may be so honeycombed with small holes ( 1 to 3 feet in (liameter) that it is impossible to walk more than a few feet without encountering one. Most of these small solution cavities or holes only extend 8 to 10 feet below the surface, but many of them. particularly the larger ones, reach down to water level and are a grent nuisance to the limestone operators since they must be cleaned out before the main body of the rock can be mined. Waters percolating throug! a limestone formation will often leach out the silica ( $\mathrm{SiO} 2$ ) contained in the deposit as the spicules of silica secreting sponges or in other forms, and deposit it in old channels, thus forming the nodules and beds of chert encountered in limestones. 
In some instances the whole mass of a one-time soft limestone may be so dissected by a large number of solution channels more or less connected that the rock has become semicrystalline by the water permeating all through it. These channels may be only a few inches wide in the upper part, but frequently near water level they form chasms 3 to 6 feet wide.
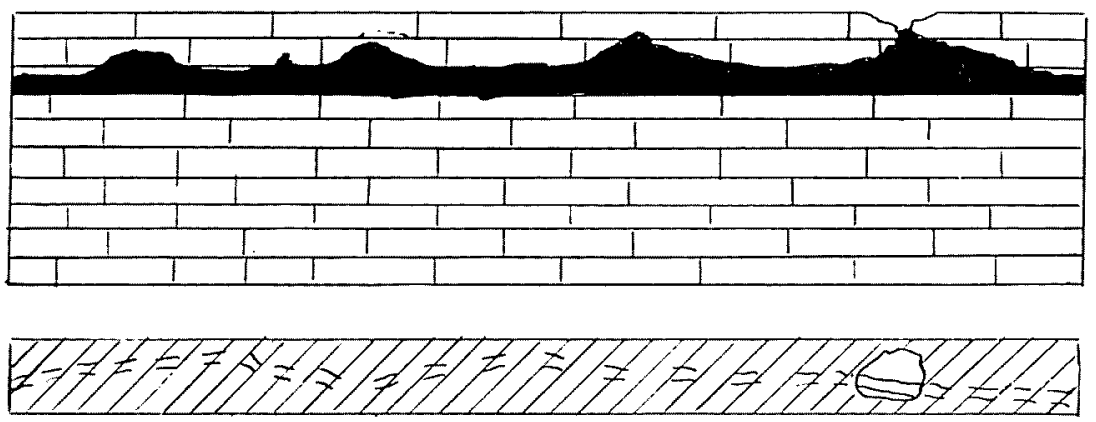

Text Fig. 2.-Early stage of solution; stream flowing in underground cavern with sink-hole and roof weakened in several places.

Ground plan: Broken lines represent course of stream in underground cavern, diagonal lines represent solid rock at surface; small open area represents sink hole.
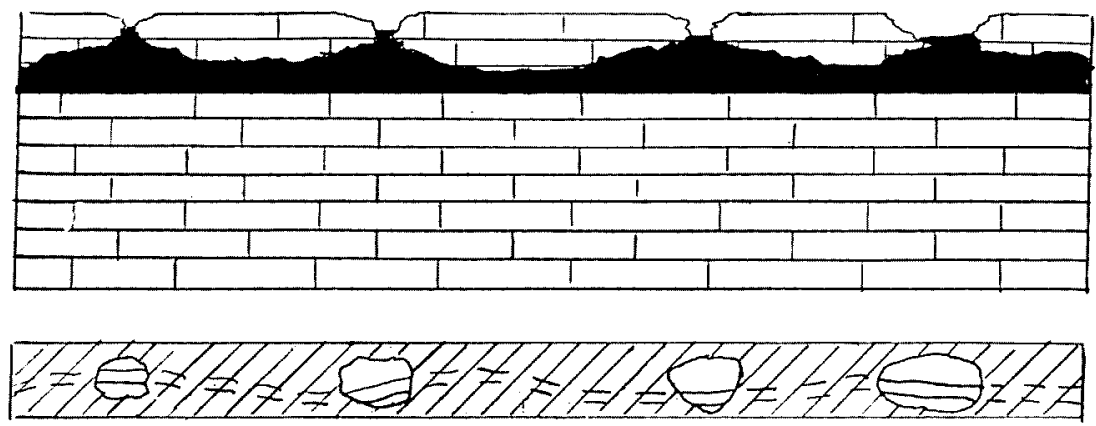

Text Fig. 3.-Solution has continued and the weakened roof has fallen in in many places until now stream runs through line of sinks.

Ground plan as in Figure 2. 

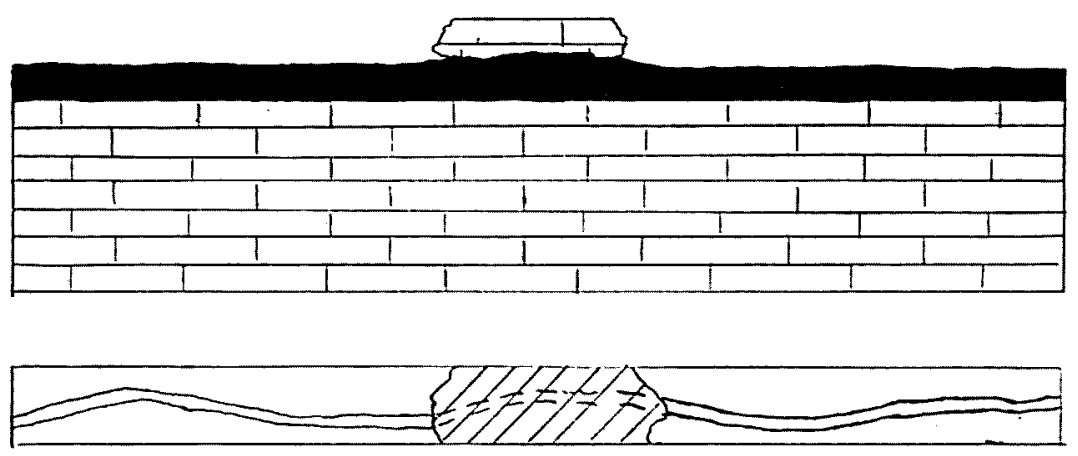

Text Fig. 4.-Advanced stage of solution; all but one segment of roof has fallen in, forming a natural bridge. Stream runs in narrow channel with steep sides, but has become a surface stream covered in only one place by the remaining portion of the roof.

Ground plan as in Figure 2.

The above ideal sketches represent one method of natural bridge formation quite common in the soft limestones of Florida.

Fossil shells, should they be present in large quantities, act as a center of crystallization; in the Ocala limestone especially, this phenomenon is well illustrated and many examples are seen where the fossil masses are inclurated and semicrystalline while the surrounding limestone, locally sparsely fossiliferous, is still soft and unaffected. This type of weathering takes place only as far down as ground-water level, for by that time the waters have lost most of their acidity and power to take any more $\mathrm{CaCO}$ : into solution and they join the ground water.

The principal work of the ground water, made up of this downward percolating rain water, is to take material into solution, transport and cleposit it elsewhere. Where the solution has become concentrated along: a bed or channel it may form an underground stream in a cavern; such a cavern may be several miles long and over a hundred feet in diameter. As the roof of this cavern becomes weakened by the continuous wearing away of the limestone, it will fall in and form a sink-hole; this is well seen in many parts of Florida, especially in the country around Gainesville and bordering the rivers in the northern part of the State. In Florida the soft porous limestones are frequently covered by a rather thick mantle of clay and sand which, though porous and permitting the water to filter through, masks the limestone, so that these sink-holes are often lined with clay and sand and the rock itself is not always seen. 
Through the activity of underground waters natural bridges are also formed, a well known example being on the main highway at Arch Creek, 14 miles north of Miami. The principle of natural bridge formation is quite simple, but often produces seemingly impossible results : as the descending meteoric waters leach out the $\mathrm{CaCO}_{3}$ and feed the underground streams, the roof is weakened and finally falls in; this progresses until the underground stream becomes automatically a surface stream with here and there portions of the roof still in place. These remaining segments are the natural bridges (see figures on pages 58 and $59)$. Another method of natural bridge formation is illustrated on pages 61 and 62 ; many of the "disappearing streams" of the State belong to this latter type: a small sink or solution channel appears in the bed of a surface stream and some of the water is drained off through it. As time goes on this new drain will become increasingly larger until it has become the main drain and only in flood times will there be sufficient water in the stream bed to overflow it and use the old surface channel downstrean from the underground drainage opening. The water that passes beneath the surface through an opening of this kind may appear some distance

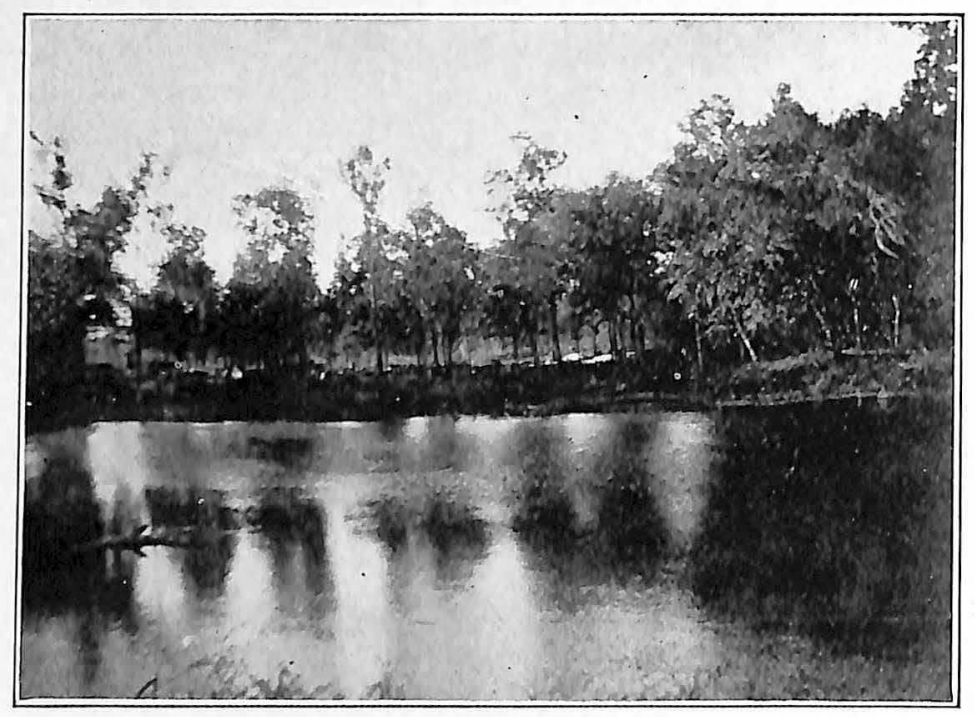

Fig. 10.- "Rise" of the Santa Fe River, Alachua County. The stream enters the ground two or three miles away, emerging again at this point. 
farther on, pouring forth as a spring or as the "rise" of the river. Lndoubtedly there are many bridges of this type that are not recognized since they are of too great size, for all the land passed under by such a strean must be a natural bridge, but on account of the length of the span and the low height, such a phenomenon is seldom noticed by the castual observer.

The weathering power of water is generally considered to stop at ground-water level or slightly below : this may be true as a general statement, but it seens certain from the meager evidence at hand that eren below water level some changes take place in the limestone. Most lime operators cease mining when water level is reached, but two pits in the vicinity of ( jus use dredges to mine the Miami oolite $? 0$ feet or more below water level and the material brought up is a hard, jagged limestone, certainly differing from the oolite lying above water level. It may be that this is explained by the ease with which calcite recrystallizes, so that even though water below gromul-water level has lost most or all of its solvent power, still its presence throughout the formation will bring about a molecular rearrangement.

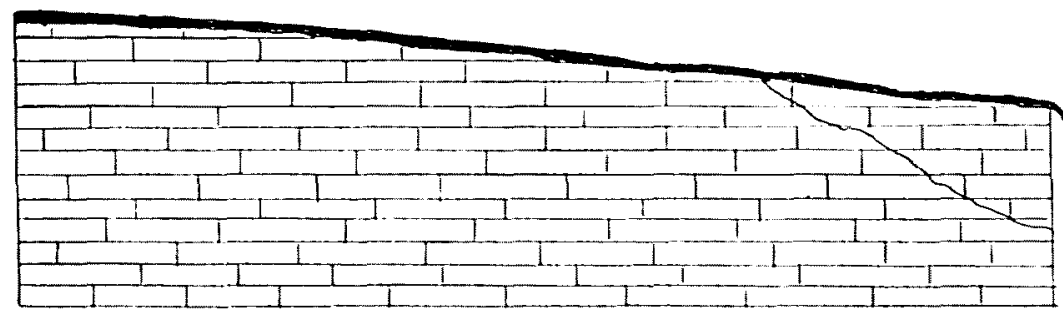

Text Fig. 5.-Flowing surface stream with a small part of the flow passing out by way of a small subterranean solution channel.

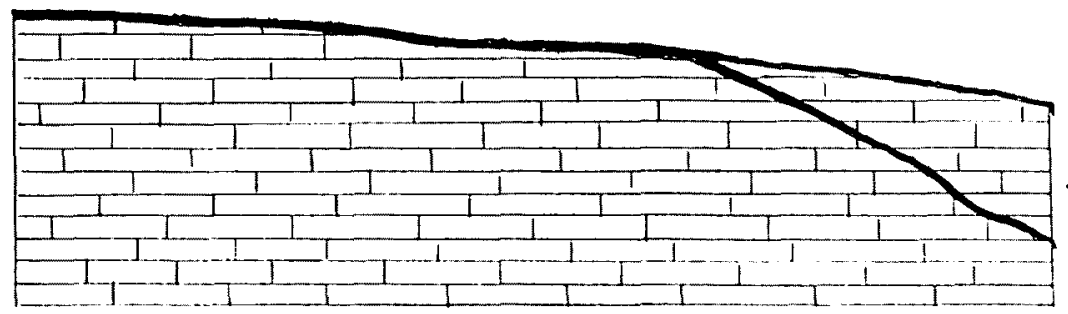

Text Fig. 6.- Solution channel has grown larger and is now main drainage except in flood time, when surface channel takes care of the overflow. 


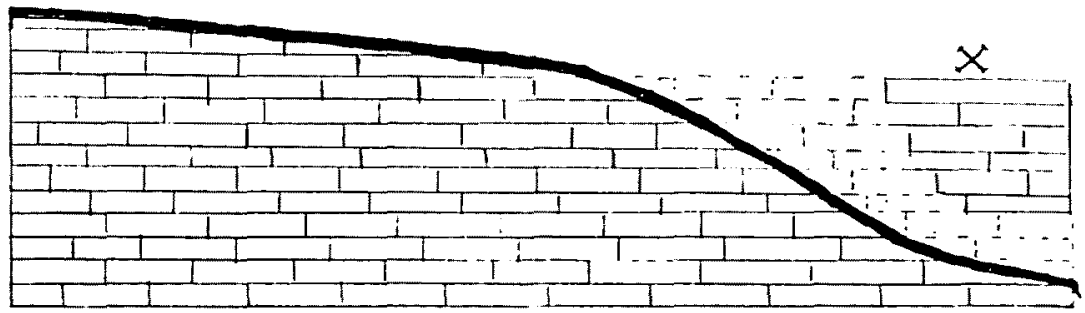

Text Fig. 7.- Solution channel has dissolved the limestone and retreated upstream, leaving limestone mass $(X)$ as natural bridge.

In a region of low relief, as Florida, the process here illustrated will not continue beyond an advanced stage of Figure 6 . The end result will be a long natural bridge with a very low span.

The above sketches show on an exaggerated scale a second method of natural bridge formation. (Modified after Chamberlain \& Salisbury.)

Secause of the geologic youth, the softness of the rock and the low relief of the country, there are no huge caverns in Florida comparable to those found in Virginia, Indiana and Kentucky. Nevertheless, in the high south central and northern portions of the State there are grottoes of considerable size and the lime-sink region around Gainesville offers mute testimony to the solvency of underground streams; that all the limestones unclerlying the State have at some time been subjected to this same action is evidenced by the repeated reports of drillers describing the "pockets" that they have passed through in the deeper lying formations. In and north of the Marianna-Chipley area sink-holes and grottoes are quite common and in southern Wakulla and Jefferson counties as well as sonthwestern laylor these phenomena accompanied by disappearing streams are well shown.

\section{SI:COND.MRY DEPOSITION}

Under "Weathering," the power of downwarl percolating water to leach out lime and deposit it at a lower level, thus forming an inclurated top layer, has been discussed. This same process if carried on in an area of fairly high relief sometimes will cause the whole deposit to be hardened and made semicrystalline. Good examples of this are the Ocala limestone at the Crystal River Rock Company pit and the Glendon limestone in the old Lyle quarry just north of Live Oak. Both of these formations were originally soft limestones, but through this leaching-out process have been altered to semicrystalline. The No. 1 pit of the 


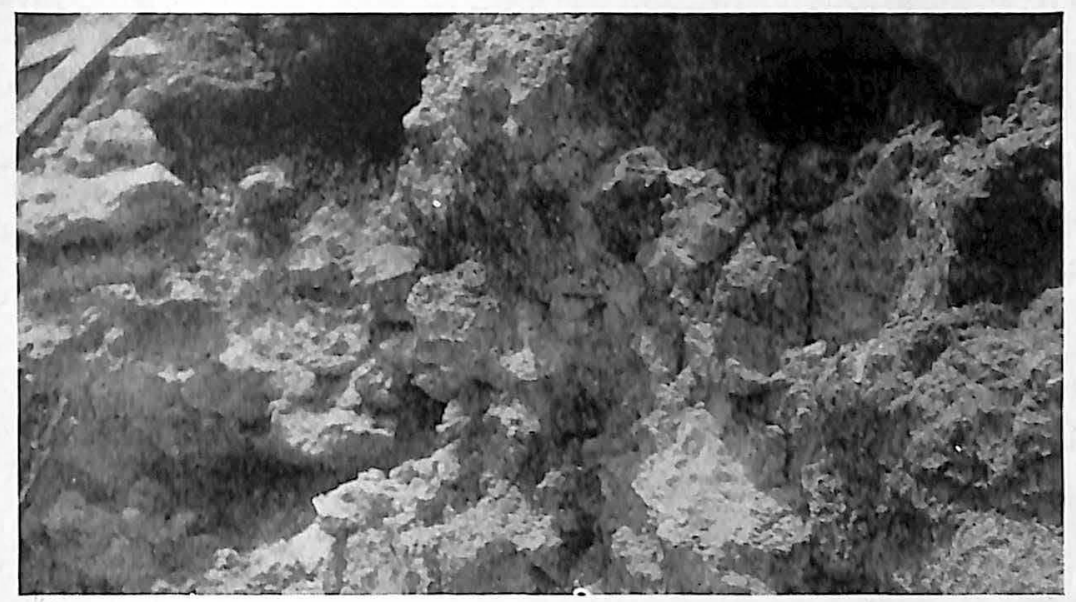

Fig. 11.-Near view of Glendon limestone in old Lyle quarry, Live Oak, Suwannee County.

Floricla Lime Company at Ocala is a third instance of this. Examples of the partial working of this secondary deposition or redeposition are found all through the Ocala limestone, the hardened masses occurring very irregularly. There is some doubt as to whether this partial recrystallization within the body of the deposit is due to redeposition, as surely the indurated surface layers are, or is the recrystallization of calcite in the presence of water. The latter is probably true of most of the irregular hardened masses in the Ocala limestone, but the hard material in the Crystal River pit and Lyle quarry seems to be due to redeposition since the whole body of rock is affected and in both cases a 10 to 15 foot bed of loose, chalky, somewhat impure material overlies the deposit and seems to be limestone from which much of the calcium carbonate has been leached.

When a marl is subjected to this process the results are bizarre indeed. Most of the marls in southern Florida are composed principally of unconsolidated sand and clay with considerable quantities of shells and shell fragments; when these marls are exposed at the surface much of sand and clay are removed by erosion, but the heavier shell matter remains, thus increasing the ratio of lime to impurities (silica, iron and alumina, etc.) in the deposit. Gentle rains provide the water which percolates down through the marl taking the lime into solution and depositing it at a lower level, because of the low relief of the country and 
the activity of ground water this "lower level" may be only two or three feet. Due to the quantity of impurities present in the marl the resulting deposition is an impure limestone, often weathered into grotesque shapes. This limestone is usually quite brittle, dense, rings under the hammer and often shows considerable laminations, due largely to the impurities, which, because of the interrupted, or rather, successive deposition are not always horizontally parallel but may be curved, wavy and often irregularly concentric.

In dredging the drainage canals in south Florida, marl is often encountered which is an oozy mass so soft that it runs out of the dipper. This marl is dumped on the spoil bank and soon becomes a hard brittle rock that is very difficult to break up and remove. Throughout the

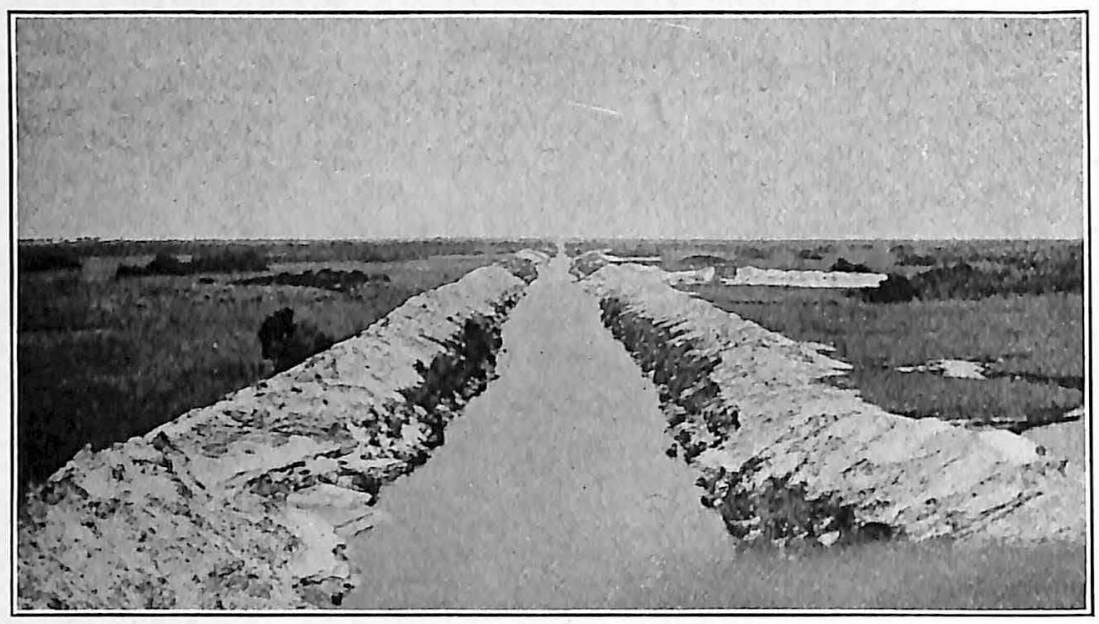

Fig. 12.-Drainage canal west of $\mathrm{Ft}$. Lauderdale showing marl on spoil bank.

whole of extreme southern Florida and particularly in the Everglades this same phenomenon is naturally exhibited, that is the material as originally laid down was a soft, oozy marl, but owing to differing conditions much of it has been hardened to an impure limestone. These masses are not regular in areal distribution and probably the marls from which they are formed are not, but it is almost impossible to trace out the separate formations. All were deposited during Pleistocene time and are essentially the same, consisting of variable percentages of $\mathrm{CaCO}$; (limestone) and $\mathrm{SiO}_{2}$ (sand), and show all transitions from the unconsolidated marl to the hard impure siliceous limestone. 


\section{TOPOGRAPHY AND GEOLOG \\ Torockiph:}

All of Florila lies within the Coastal Plain province and is underlain by soft, chictly calcareous formations of Tertiary and Quaternary age. The highest elevation is only about 350 feet, but in spite of this there is an unexpected variety of topographic expression.

Everywhere south of the northern end of Lake Okeecholsee and bordering the peninsula farther north on both the Atlantic and Gulf sides, are the lowlands, a strip of comntry of variable width all lying below the fifty-foot contour line and composed mostly of Pliocene and Pleistocene sands, limestone and marls. This section, which comprises over one-half of the total area of the state, has been practically unaffected by erosional forces and crustal disturbances and, except for sand dumes and stream channels, lies on a level, in the same position as when it was formed.

In parts of the upland section of the State the relation of erosion to topography can be readly seen, for here the rainfall aided by humic acids has had a solvent effect on the underlying limestones, thus producing a characteristic solution topography rather difficult of description, for the topographic features seem to follow no regular lines, but are a series of basins or clepressions of variable width and depth with accompanying hills of variable height and breadth. Two areas in particular are worthy of mention in the "highlands" which extend down the axis of the peninstula and are unclerlain by calcareons material: the "lime-sink" region which lies chiefly along the west flank and the "lake region" trencling toward the east sicle of the peninsular axis. In the former the limestones lie near the surface and the process of solution has resulted in a series of shallow dry or water-filled basins or fluctuating temporary lakes connected by underground drainage. In the "lake region" the limestones lie deeper and the lakes are not known to have subterranean outlets and are of a more permanent nature.

In western Florida, including Fscambia and Santa Rosa comties, as well as in Gadsclen and the northern part of Liberty comnties, the limestones lie at considerable depth and exert little or no influence on the surface features. Here the topography is determined by natural drainage courses and normal erosion, 


\section{STRUC'TURE}

The Floridian platean, jutting out and separating the Gulf of Mexico from the Atlantic Ocean, presents an unusual structural feature in coastal plain geology. The exact time of its formation has not been determined. Uniform sediments of Eocene (Jackson) age are widespread over all of the peninsula and constitute the oldest exposed formation. From a broad, low-domed structurally high area in the northern central part of the peninsula around Gainesville and Ocala, the Ocala limestone, the oldest exposed formation in Florida, dips south and southwest at about 6 feet to the mile; in the Tampa embayment this dip scens to be increased and the direction changed to south and southwest. The younger formations resting conformably or with but slight unconformities upon the Ocala seem to have the same general dip.

In that part of Floricla west of the Choctawhatchee river the linestones lie at considerable depth beneath the surface and there are not enough well records to give any detailed description of the structural conditions. It is probable, however, that with very low folds, the Ocala dips gently toward the south and southeast.

Between the Choctawhatchee and Apalachicola rivers, with its axis nearer the former, is a broad structurally high area that brings the Marianna limestone (lower Oligocene) to the surface at the town of Marianna and also exposes in the same area the underlying Ocala limestone of uppermost Eocene age. From this point these formations dip to the south and southeast, forming a broad shallow syncline or trough between the Apalachicola and Ocklocknee rivers. East of the Ocklocknee in southern Wakulla County and to the northeast around Live Oak in Suwannee County are slight structurally high areas whose extent and size are as yet not well defined. The mere presence of the Ocala limestone at the surface does not, in itself, mean that there have been crustal disturbances resulting in the formation of a broad anticline or dome. Without a doubt erosion has played a consiclerable part in molding the topographic features of the Floridian plateat; so that although certain areas are considered structurally "high," erosion, as well as crustal deformations, must be considered as an important factor. 


\section{STRATIGRAPHIC GEOLOGY}

The geologic column as discussed in this report is given below; the exact position of many of these formations is somewhat doubtful, as some are in large part contemporaneous. This matter is discussed more fully in the text.

PLEISTOCENE

PLIOCENE

MIOCENE

OLIGOCENE

EOCENE (Jackson)
Coquina

Marls (undifferentiated)

Key West oolite

Miami oolite

Key Largo limestone

Nashua marl

Caloosahatchee marl

Choctawhatchee marl

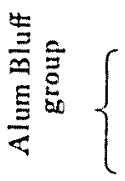

Shoal River marl

Oak Grove sand

Chipola marl

Chattahoochee formation

Tampa formation

$\underbrace{}_{3}=\begin{aligned} & \text { Glendon formation } \\ & \text { Marianna limestone }\end{aligned}$

Ocala limestonc 


\section{EOCENE SERIES}

\section{OC.NLA LIMESTONE}

Name-'This name was first applied by Dall' in 1892 to the Nummulitic limestone beds exposed around Ocala in Marion County. Eleven years earlier Eugene A. Smith" had given an account of limestone underlying large areas in western and peninsular Floridla which he correlatel with the Vicksburg limestone of Alabama and Mississippi and to which he applied the name "Vicksburg limestone."

Two years later, or in 1883, Heilprin described these Nummulitic rocks and discriminated between them and the Orbitoides or Vicksburg limestone, which both he and Dall considered to lie beneath the Nummulitic beds. In 1903 Dall" proposed the abandonment of the name Vicksburg as applied to the limestones of the Floridian peninsula and the adoption of the name "Peninsular" for the former Vicksburg or Orbitoides rock; this was done because the limestone that forms the mass of the plateau was felt to be different from the typical Vicksburg. possibly occupying a position intermediate between it and the Ocala.

In $1909^{4}$ Matson and Clapp, and later in $1913^{5}$ Matson and Sanford followed Dall's opinion and considered, with exact correlations doubtful, the Ocala limestone to overlie the "Peninsular" and the Marianna and included all three in the Vicksburg group of Upper Oligocene age.

In 1915 Cooke ${ }^{6}$ gave the results of a study of these formations in the course of which he discovered the Marianna-Ocala contact on the Chipola river near Marianna and thus determined the correct stratigraphic position. On paleontologic evidence he assigned the Ocala limestone to the upper Eocene (Jackson), quoting from his paper: "It has been shown that the Ocala limestone is the equivalent in age of the upper part of the Jackson formation as defined in Alabama and Mississippi and that it underlies Vicksburgian limestone in western Floricla.

${ }^{1}$ Dall, W. H.: The Neocene of North America. U. S. Geol. Survey Bull., 84, pp. $103-104,1892$.

"Smith, Eugene A.: On the Geology of Florida. Am. Jour. Sci., 3rd ser, vol. 21, pp. 292-309, 1881.

'Dall, W. H.: Wagner Inst. Trans., vol. 3, pt. 6, 1903.

tMatson, G. C., and Clapp, F. G.: Florida Geol. Survey, 2nd Ann. Report, 1909.

"Matson, G. C., and Sanford, Samuel: U. S. Geol. Survey, Water-Supply Paper, 319, 1913.

"Cockc, C. W.: U. S. Geol. Survey Prof. Paper 95, i, 1915. 
As the relations are conformable, the Ocala must represent at least the upper portion of the Jackson formation. but whether the lower portion of the Jackson in peninsular Florida is different from the Ocala, either lithologically or faunally, is at present unknown."

In this report all the soft pure limestone found in the State bearing Lepidocyclina. Orthophramina and other associated fossils characteristically present at the type locality in the rocks near Ocala is consirlered to belong to that formation.

Lithologic description-The Ocala consists of a light-colored almost white, cream-yellow to gray very pure linestone. When fresh this rock is cream-white. soft, porous and granular. but on exposure to the air may bleach out chalk-white. Because of its softness and porosity it readily permits the formation of solution chamels and pot-holes by descending water. with the accompanying leaching out and redeposition of $\mathrm{CaCO}:$. Thus, some of the limestone, especially that exposed at the surface, is hard and semicrystalline and throughout the main body of the rock, about masses of fossil shells, which occur in great profusion, and where water has percolated clownward. the limestone may also be of a semicrystalline nature. Nodules and lavers of chert occur and in some localities a large part of the surface rock has been silicified. The rock is extremely uniform in texture and chemical purity; and it has been known to run as high as 99.6 per cent $\mathrm{CaCO}_{3}$.

Paleontologic description-The Ocala contains many Orbitoides (chiefly of the genera Orthophragmina and Lepidocyclina). Nummulite; and other foraminifera as well as bryozoa, molluses, chinoids and gastropods. The most common mollucan and echinoid forms found in this formation and more or less peculiar to it are: Amusimm ocalanum, Plicatula (Ocala sp.) Pecten forplanus, P. sticannonsis, Cassidnlus haldermani and $C$. arctherbyi.

The foraminifera are excedingly abundant in the Ocala limestone and in many places make up the main body of the rock: particularly abundant and characteristic are: Lepidocyclina oculana Cushman (macroand microspheric forms), L. floridana Cushman, and L.ocalana var. subdecorata Cushman.

Structure and thickn'ss-No complete section of the Ocala has ever been taken, as the lower boundary is nowhere exposed. The greatest 
thickness observed was at the quarry of the Crystal River Rock Company near Crystal River, Citrus County, where there is a working face of 115 feet. Well records are unreliable, but judging from lithology alone the thickness given by several cleep borings in various parts of the State is from 150 to 400 or more feet. The Ocala, from a structurally high area around Gainesville and Ocala, dips very gently to the south and southeast. To the north of this area and in western Florida east of the Apalachicola river are other slightly high areas as explained under "Structure" at the beginning of this chapter.

Physiographic expression-Because of its softness and porosity, the Ocala has given rise to a topography marked by sink-holes, caves, underground channels, disappearing streams and large springs. Silver Springs, a few miles east of Ocala in Marion county, pours forth from this limestone, and many of the temporary lake basins have been formed in it. Its influence is strongly felt in the Payne's Prairie region southeast of Gainesville, and in general all through this central portion of the State. Natural Bridge, Natural Cave and the rock masses around Waddell's Mill Pond in Jackson county north of Marianna are all in Ocala limestone, considerably altered by weathering.

Areal distribution-Although the Ocala limestone presumably underlies the whole State, it has in comparison only a small areal extent. It is exposed in the northern part of Jackson county, and in the center of the State it outcrops or immediately underlies a large area consisting of southern Suwannee, eastern and southern Lafayette, western and sonthern Union, western Alachua and Marion, northern Hernando and practically all of Dixie, Levy and Citrus counties. (See Map.)

Economic uses-The greatest tonnage of Ocala limestone quarried goes into highway construction, though one plant quarries a hard phase of the stone for railroad ballast and three plants use the rock in the manufacture of agricultural, hydrated, lump and quicklime. Once on the market as hydrated or quicklime the material has innumerable uses in the builcling, chemical and industrial world. As one of the principal ingredients of Portland cement this rock would be of consiclerable value because of its low magnesium content and other impurities as well as for its softness, the size, accessibility and uniformity of the deposits. 


\title{
OLIGOCENE SERIES
}

\author{
MARIANNA LIMESTONE
}

Name and Stratigraphic Position-The name Narianna limestone was given by Matson and Clapp in 1909 to the "soft, porous, light-gray to white limestones of western Florida. which are characterized by an abundance of Orbitoides mantelli and other foraminifera associated with many other fossils, prominent anong which are Pecten poulsoni and $P$. perplanus."

The formation received its name from the type locality, around the town of Marianna in Jackson County, Florida, where for many years the limestone has been sawed into building blocks used principally in builling chimneys, so that popularly the limestone is called "chimney. rock." Matson and Clapp distinguished it from the Ocala and "Peninsular" limestones, believing it to underlie these: all three formations being placed in the Vicksburg group of lower Oligocene age; the exact correlations were doubtful. In the stratigraphic discussion it was inclucled with the "Peninsular" limestone because of the close lithologic resemblance and the fact that no defining contact had been found. In reporting thickness the two formations were again given together or in many instances simply called "Yicksburg limestone." These thicknesses ranged from 225 feet at Quincy to 250 feet at Alachua and 325 at Bartow.

Since that time adclitional work has been done on these pure soft limestones which has solved many of the problems of stratigraphic relationship. Cooke $\mathrm{e}^{2}$ gives the section on the Chipola river at Marianna where he found 33 feet of the Marianna limestone resting upon the Ocala. The discovery of this contact made clear the stratigraphic relation of the Marianna to the Ocala, as well as giving the first definite thickness to the Marianna formation. The Marianna is now considered to represent in Florida the lowermost formation of the Vicksburg group of lower Oligocene age, and, at the type locality, to rest conformably upon the Ocala of E,ocene (Jackson) age.

Lithologic description-The Marianna is a very pure, soft, chalk-

${ }^{1}$ Matson, G. C., and Clapp, F. G.: Second Annual Report of the Florida Geological Survey, p. 52, 1909.

"Cooke, C. W.: "Age of the Ocala Limestone," U. S. G. S. Prof. Paper 95, i, p. $109,1915$. 
like limestone, quite close-even-grained and exceedingly homogeneous. When fresh it has a slightly cream-yellow appearance; sometimes this discoloration is in streaks, but upon exposure to the air and sunlight the limestone bleaches out to a chalk-white. Though not quite as pure as the Ocala the Marianna will analyze $93 \%-95 \%$ in $\mathrm{CaCO}:$. Along the Chipola river or in other stream bottoms where the formation has been exposed to the long continued action of water and other weathering agencies, the normal soft "chimney-rock" phase has been altered to a hard and compact light-colored limestone, in places locally semicrystalline. Because of its fine, even texture and homogeneity the stone has for years been sawed out by hand with regular timber saws and used in the construction of chimneys, house supports and, lately, as a regular building stone. The stone in its natural occurrence is quite "damp" and easily cut, so that simply by the addition of a small steady stream of water at the sawing surface it cuts smoothly and uniformly.

Paleontologic description-The Marianna at and around the type locality is not abundantly fossiliferous, and no critical study of complete collections has been made, so that not a great deal is known of the fauna. Probably the most characteristic fossil is the large orbitoid foraminifer Lepidocyclina mantelli (Morton). Pecten poulsoni (Morton) also occurs, but ranges through the entire Vicksburg group and is not restricted to the Marianna; Clypeaster rogersi (Morton) has also bee!l reported from this locality, but it, too, ranges through the entire Vicksburg group and is not restricted to the Marianna.

Structure and Thickness-The 33 feet of the Marianna as exposed! at the type locality is the greatest known thickness attained by this formation in Florida. In structure, the formation is of too limited areal extent and too greatly eroded to secure any definite data. It secms to lie practically horizontal, or, following the underlying Ocala, have a slight dip to the south and southeast.

Physiographic expression-As would be expected of such a pure soft limestone, the Marianna shows a surface topography greatly influenced by solution and characterized by caves, irregular depressions. rounded hills and underground streams, as evidenced by the spring: pouring forth from the limestone. In many places the formation is covered by a thick mantle of sand and sandy clay and here the country takes on a more rolling appearance with gentle slopes, as in Rabb's valley southeast of Chipley. 
Arcal Distribution- $\mathrm{I}_{n}$ areal extent the Marianna is one of the smallest formations in the Florida section, its occurrence being noted in but one county. Jackson, and only in a relatively small area there. The outcrop of this formation is in shape roughly elliptical on a northwestsoutheast axis, with the town of Marianna in the center: north of this place the limestone extends only three or four miles and a much less distance to the south; to the east about seven and to the west, just beyond Cottonclale. To the northwest the limestone can be seen in scattered outcrops on the Marianna-Camplellton road up to about three miles south of Wadclell's Mill Pond. The Marianna here must not be confused with the Ocala, which is seen along the same road but two or three miles farther north. In this vicinity both formations have been quarried on a small scale for chimney blocks and may be confused upon hasty examination. The limestone at and around Duncan in Washington County is now known to belong to the Ocala formation, and the rock in the vicinity of Chipley and southeast of there is now referred to the Glendon: botl of these localities were formely believed to belong to the Marianna.

Economic Uses-The popular name, "chimney rock," gives a clue to the most important economic use of this soft limestone. For years. farmers in the vicinity of Marianna have sawed out slabs of soft stone, piled the "green" blocks up to season them and built chimneys, house supports and in many instances whole buildings of this chalk-white stone. So far as is known the rock has been very little if ever used for road material, in the manufacture of quicklime or any of the numerous uses of a soft pure limestone: this has probably been due to many different reasons, chief among which are the limited demand and the quantity and accessibility of substitutes.

\section{GLENDON FORMATION}

Name-The Glendon formation was named by Cooke from a village in Clarke County, Alabama, and was first described as the Glendon limestone member of the Marianna limestone. Cpon further investigation it was found that beds of Glendon age have a wider distribution than the typical Marianna, that they transgress older formations and contain a large and characteristic fama, so that now the Glenton is regarded as of formational rank."

${ }^{1}$ Cooke, C. W.: "Correlation of the deposits of Jackson and Vicksburg ages in Mississippi and Alabama." Journal, Washington Academy Science, vol. 8, p. 195, 1918.

"Cooke, C. W.: "The Correlation of the Vicksburg Group." U. S. G. S. Prof. Paper 133, p. 3, 1923. 
Much of the "Hawthorne formation" of Da11 ${ }^{3}$ as well as most of the limestone in north and west Florida formerly considered Chattahoochee are now included in the Glendon. Dall referred the !imestone exposed in the Suwannee river at Ellaville to the Hawthorne and also the thin boulder beds found in the phosphate workings at High Springs and other points in this vicinity. The type locality was near the town of Hawthorne in Alachua County where the silicified and cherty limestone was formerly quarried. He noted the frequent occurrence of thin silicified boulder beds as the sole representative of this formation in peninsular Florida and the occurrence of "an echinoid belonging to the genus Cassidulus," in the limestone at White Springs and elsewhere. This seems without a doubt to be the Cassidulus gouldii (Bouvé) which is quite profusely distributed throughout the Glendon formation and, so far as is known, limited in occurrence to this one horizon.

Stratigraphic Position and Thickness-Stratigraphically the Glendon conformably overlies the Marianna (though the actual contact has not been seen in Florida), and represents in this State the uppermost for-

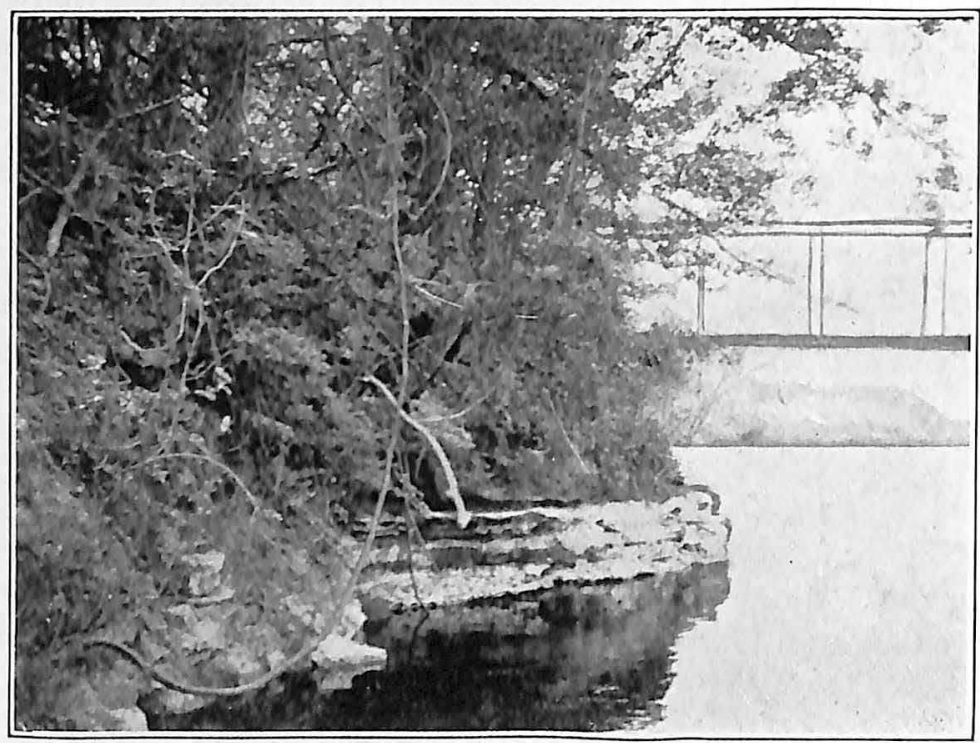

Fig. 13.-Outcrop of Glendon limestone on Suwannee River, opposite Ellaville, Suwannee County.

${ }^{3}$ Dall, Wm. H.: "The Neocene of North America." U. S. Geol. Survey, Bull. 84, pp. 105-123, 1892. 
mation of the Vicksburg group (Oligocene). On the Suwannee river at Ellaville the Glendon limestone can be seen resting unconformably upon the Ocala limestone. The base of the Glendon is not exposed in the western part of the State, and consequently no accurate measurements of the thickness can be given. In sink-holes southeast of Chipley the exposed thickness varies from 38 feet to 45 feet. At Falling Water southwest of the same town the formation has an exposed sheer face of $661 / 2$ feet; this latter is the greatest thickness observed.

Lithologic description-The Glendon consists of two facies-where the cover has been removed and the weathering active, the formation is represented by thick beds of variegated red-yellow residual sands and clays, usually light-colored, with lumps of chert; this phase is well developed in northern Holmes County, particularly in the country bordering the Choctawhatchee river.

Under cover or where the weathering agencies have not been so active the limestone phase is seen. The Glendon limestone is soft, pure and compact, cream to light yellow in color when fresh and bleaching out chalk-white. It is largely made up of the shells of foraminifera and other minute organisms, these harder particles bound together by soft amorphous lime material, with the result that the whole mass is much more compact and not at all as granular or powdery as the Ocala limestone. When struck with the hammer the stone fractures irregularly and in all directions, leaving rough, jagged faces. Weathering agencies act easily on this limestone, as is evidenced by the hard, tough cavernous surface boulders in the west Florida exposures. In the vicinity of Live Oak. Suwannee County, the whole limestone mass has been altered and made semicrystalline by these weathering agencies to a depth of at least forty feet. 'This limestone so affected is not uniformly hardened, but consists of irregular rounded and lenticular masses of semicrystalline material with interspaces of somewhat softer material. Northward all along the Suwannee river and particularly in the vicinity of Suwannee Springs this hardening of the limestone by water action can be seen.

Palcontologic description-The fama of the Glendon has not been fully studied, but from the work done so far only one form, an echinoid Cassidulus souldii (Bonvé) is considered restricted to the formation. The following ${ }^{2}$ species occur in the formation:

llbid., p. 7 . 


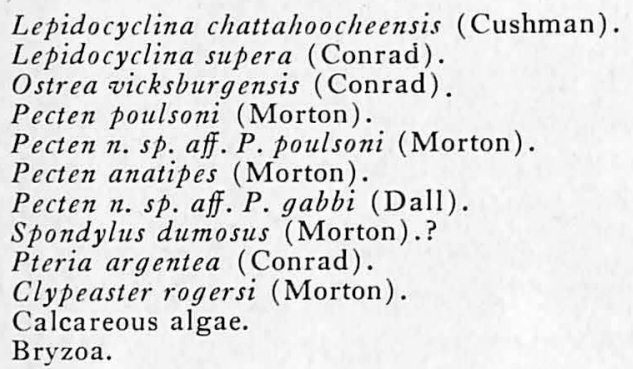

Areal Distribution and Dip-Most of the area in northern Florida formerly mapped as Chattahoochee is now considered of Glendon age. The formation outcrops in a wide belt over most of northern Holmes County, part of northeastern Washington and southern, southeastern and southwestern Jackson. The limestone phase is present in a comparatively small area around Chipley in northeastern Washington County; dipping gently to the southeast it passes out beneath the sands

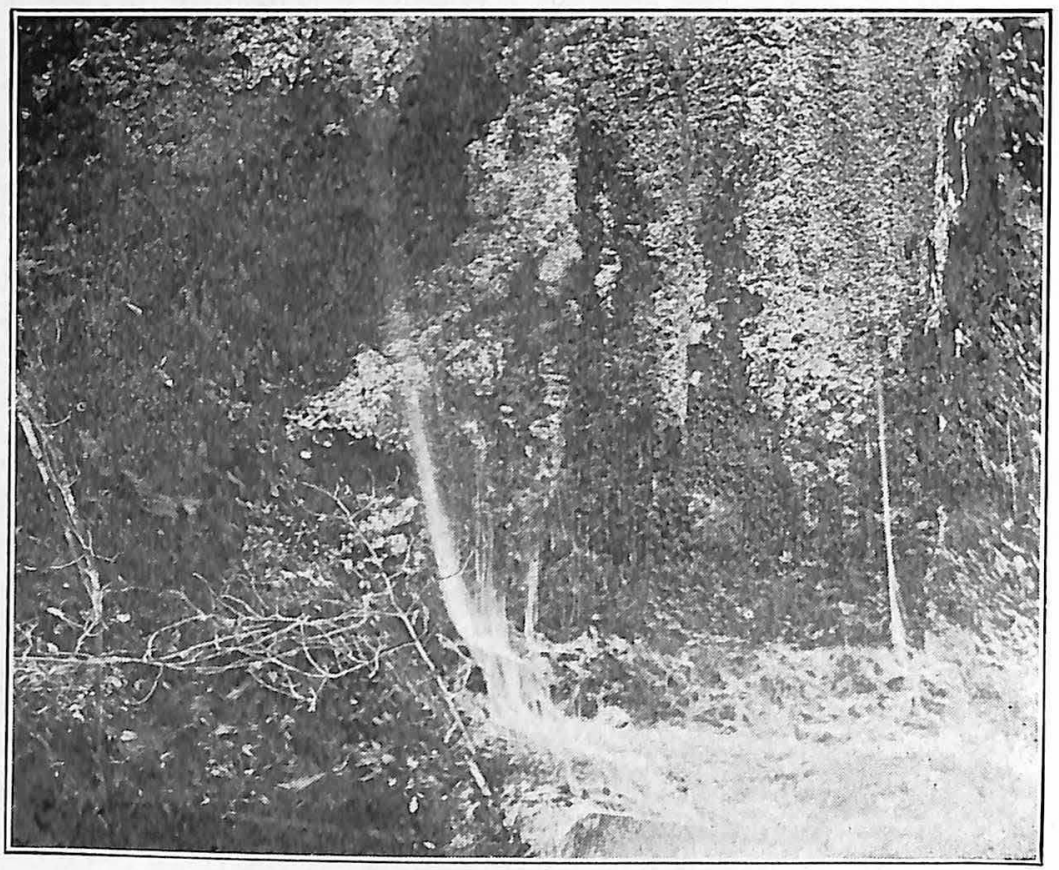

Fig. 14.-Glendon limestone in Falling Water sink, five miles south of Chipley, Washington County. 
and clays of the Alum Bluff. Just east of the Chattahoochee river the Glendon has not definitely been traced; it probably lies below the Alum Bluff sediments here and ioes not appear at the surface. Onterops of this limestone are seen in the vicinity of Lake Miccosukee in northern Leon and Madison comnties and to the east all the rivers, Withlacoochee. Alapaha and Suwannee, have cut down through the younger beds and have their channels in the Glenton limestone. In the area around Live Oak to the east and north, the Glendon lies very close to the surface and outcrops in many places. East of Live Oak the Glendon is again covered by Alum Bluff cleposits; to the south the Glendon is absent, probably due to erosion of sediments down to the Ocala limestone, for in phosphate workings at High Springs and as far south as Dumnellon. residual boulders of Glendon limestone are found. The limestone around Brooksville in Hernando County has many features in common with the Glendon, but the exact stratigraphic relations require more study before they can be stated with any accuracy.

Ficonomic Uscs-The hardened phase of the limestone has led to its use for railroad ballast and, on a small scale, as a concrete aggregate, building stone and in the manufacture of quicklime. The softer phase has not been used but is first-rate material for highway purposes and also in the manufacture of quicklime and cement.

\section{MIOCENE SERIES}

\section{TAMPA FORMATION}

The limestone exposed around Tampa was examined by Conrad ${ }^{1}$ as early as 1846. Subsequently many other geologists-Allen,-' 'Toumey; Kerr and Mitchell ${ }^{4}$ and Heilprin" -all visited the locality and published accounts of their investigations. Dall published an account of his studies of this area in $1892^{96}$ and this, together with his later papers, give more complete descriptions of the Tampa exposures and show that there are two beds represented which he designated the Tampa silex

${ }^{1}$ Conrad, 'T. A.: Observations on Eocene formations and descriptions of 105 new fossils of that period from the vicinity of Vicksburg, Miss. Proc. Philadelphia Acad. Sci., vol. 3, pp. 19-27, 1848. Am. Jour. Sci., 2nd ser., vol. 2, pp. 36-48, 1846.

-Allen, J. H.: Am. Jour. Sci., 2nd ser., vol. 2, pp. 36-48, $18+6$.

"Tuomey, M.: Notice on the Geology of the Florida Keys and the southern coast of Florida. Am. Jour. Sci., 2nd ser., vol. 11, pp. 390-394, 1851.

4 Mitchell, Elisha, and Kerr, W. C., Scientific Soc., p. 87, 1884.

-Heilprin, Angelo: Explorations on West Coast of Florida. Trans. Wagner Free Inst. Sci., vol. 1, pp. 10-11, 1887.

'Bull. No. 84, U. S. Geol. Survey, pp. 112-113, 1892. 
bed (lowermost) and the Tampa limestone (uppermost). Because the "silex bed" is characterized by the presence of the gastropod Orthaulax pugna.t, Dall called this the "Orthaulax bed" and the limestone above the "Ccrithium rock" on account of the many specimens of that genus there present. Matson in $1909^{s}$ obtained additional information concerning these rocks; he shows the presence of a limestone below the silex bed and the existence of clay beds at both the top and base of the formation. The clay at the top of the formation was later, in $191: 3,{ }^{9}$ by Matson believed to belong to the Alum Bluff group. The limestone underlying the "silex bed" he thought to be the same as that above ("Cerithium rock"of Dall) and the "silex bed" merely to be a zone of replacement in this limestone formation. This last account is now accepted as correct.

Stratigraphic position-Matson ${ }^{10}$ bases his evidence of an unconformity upon the results of wells drilled in the city of Tampa. In one well after passing through thirty feet of limestone and chert the drill encountered forty-one feet of clay, while in a second well, two hundred feet away, at about the same depth sixty-four feet of the same clay was drilled through. This variation was interpreted to mean that the underlying Ocala limestone has an irregular surface produced doubtless by erosion.

The present writer saw the contact of the Tampa and the Ocalat limestones in a narrow prospect shaft on the Tournley property about two and a half miles southwest of Istachatta. Hernando County. 'The hard Tampa limestone outcrops at the surface here and rests with seeming unconformity upon the soft pure Ocala at a depth of thirty-nine and a half feet. The exact relation conld not be well observed as the prospect pit was very narrow and consequently the light was very poor at the bottom and the soft Ocala had only just been encountered. The post-Oligocene beds present above the Tampa limestone rest upon it unconformably.

The exact relation of the Tampa to the Glenclon is not clear by any means, the presence of Orthaula.r pugna.t and certain corals in both formations has led to the assumption that they are, in part at least, contemporaneous. The fossils on which this information was based were col-

\footnotetext{
TOp. cit.

'Matson, G. C., and Clapp, F. G.: Florida Geol. Survey, 2nd Ann. Report, pp. 85-86, 1909.

"Matson, G. C.: U. S. Geol. Survey, Water Supply Paper 319, p. 103, 1913.

10 Idem, p. 103.
} 
lected from the Tampa at Ballast Point and nearby places and from the Glendon (then considered Chattahoochee) in southern Georgia. The linestones found in other areas and referred to these two formations have not been studied paleontologically, but were examined during the course of field work for this report and certain similarities noted. In the Glendon in Hamilton and Suwannee counties the fossils are predominantly pelecypods preserved as casts and impressions and the echinoid Cassidulus souldii (Bomve), considered restricted to this formation, is fairly abundant. In the limestone, considered here Tampa, in Hernando County the general famal assemblage is strikingly similar, both in manner of preservation and individual character, as far as can be determined in a cursory field examination; moreover, in the Florida Rock Products pit just west of Brooksville many specimens of the Cassidulus gouldii were collected. Further detailed stratigraphic and paleontologic work is necessary to throw more light on this difficult problem and additional information may result in furthering the theory of contemporaneousness, with definite boundaries to each formation or else will include all these similar limestones in one formation with definite faunal zones.

At the present time the linestone around Tampa Bay is typically the Tampa formation of lowest Miocene age. The rock near Brooksville is tentatively referred to this formation. The restricted Chattahoochee is thought to be contemporaneous with the true Tampa.

Litholosic description-In the vicinity of Tampa the rock is usually: a fairly hard. compact but not semicrystalline, light gray to yellow limestone. Fossils preserved as casts and nolds which have been left by the solution of the original shells are abundant in most exposures. The "silex bed" represents a silicified zone in this limestone and is therefore a zone of replacement, nodules of chert occur at other horizons throughont the limestone. "The fossils in this "silex bed" are replaced by the siliceous mineral chalcedony which gives then a beantiful and delicate coloring as well as faithfully reproducing the minute details of the original structures. These weathered out of the limestone and were found lying upon the ground or else imberded in a soft "rotten" matrix: Ballast Point was a famous collecting ground in former days, and this place and the specimens gathered there were carefully studied, but tourists and collectors have long since exhausted the available material and collections of these famous forms can no longer be made.

The limestone in Hernando County, particularly accessible in quar- 


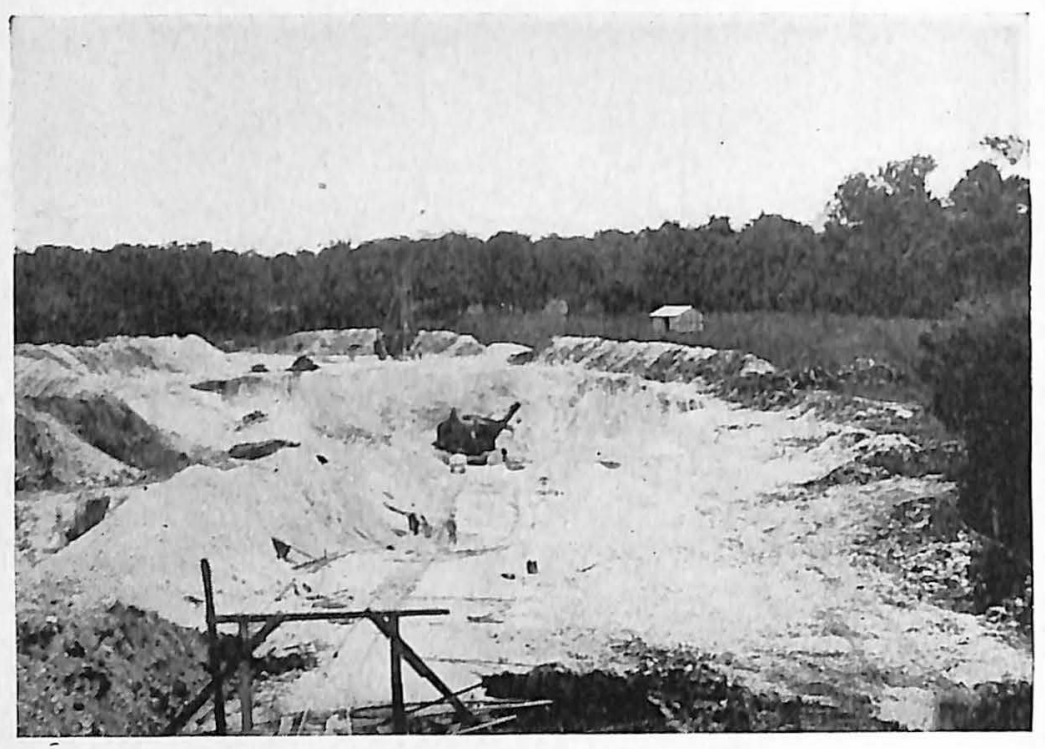

Fig. 15.-Tampa limestone in pit of Florida Rock Products Company, Brooksville, Hernando County.

ries in the Brooksville area, is referred to the Tampa formation, but differs in lithology from the type area and shows variations even in this region. The usual phase is an almost semicrystalline cream to light gray rock, sometimes with many voids due to casts and molds of fossils, other times quite dense and homogeneous, but always has an irregular fracture much like that of fuller's earth; on the fresh face the rock often has a slight greenish color and inorganic stains, again reminiscent of fuller's earth. Another phase of the Tampa is a rather soft amorphous white limestone that shows the same fuller's earth-like fracture; scattered irregularly through this softer material are small masses or lenses of dense light to dark brown crystalline limestone. In northwestern Hernando County the Tampa limestone outcrops in hard indurated surface boulders with considerable flint; one artificial exposure in this section shows about nine feet of limestone in a fresh face; this material occurs in irregularly fractured masses of almost completely crystalline dense fine-grained limestone, light gray to white in color that weathers into easily crumbled material with a light green to yellow color and the characteristic fuller's earth-like fracture. In these two last mentioned phases no fossils in any form were seen. 
Palcontolosic description-The paleontologic record of the Tampa formation is almost entirely based on Dall's studies of the "silex bed" fossils since these forms are beautifully preserved, in marked contrast to the organic remains in other parts of the limestone. Orthaular fugnar is characteristic of the "silex bed" of the Tampa limestone and this horizon has furnisherl a wreat number of species of corals, gastropods, pelecypods and a few Orbitolites floridanus which are quite abundant in the limestone overlying this bed at Ballast Point. The complete list of fossils from the "silex bel" was given by Dall." "wo noted the closeness of relation to the Oak Grove and Chipola formations as well as the assembly of land shells present in the formation which is predominantly marine.

Arcal distribution-Limestone of the Tampa formation ontcrops at Ballast P'oint on the north side of Hillsborongh Bay, at Six Mile Creek east of 'Tampa, and at intervals along the Hillsborough river in the north-central portion of Hillsborough to the Pasco County line. In the east sicle of Hillsborough liay, Pleistocene marls mask the limestone and over the eastern portion of the county unconsolidated sands and clays of the Alum liluff overlie it. Limestone referred to this formation outcrops in small anounts in northern Pinellas County around Sutherland and Tarpon Springs though covered in many places by a heavy sand mantle; it also underlies all of Pasco and Hernando comties with the exception of a narrow strip along the eastern boundaries from Istachatta to Date City and Richland. In the northern part of this area the Ocala limestone outerops and in the southern part around Dade City and southward the Alum biuff enters the section. In a small area over most of extreme southern or southwestern Citrus Comnty, the Tampa limestone outcrops or lies beneatl a sand and soil mantle of variable thickness.

Economic uscs-'The limestone of the 'Tampa is most accessible for economic development in western l'asco and central an! northwestem Hernanclo comties. In this area the predominant phase is a hard, almost semicrystalline limestone slowing an abrasion test with a per cent of wear of $6.3 \%$ and a French coefficient of the same figure. At present the material is guarried for railroad ballast, topping material in road surfacing. concrete aggregate and other uses of hard crushed stone. The

${ }^{11}$ Dall, W. H.: Tertiary fauna of Florida. Trans. Wagner Free Inst. Sci., vol. 3 , pt. 6, pp. 1564-1568, 1893. Also Dall, W. H., A monograph of the molluscan fauna of the Orthanlax Pugnax zome of the Oligocene of Tampa, Florida. U. S. Nat. Museum Bull. 90, 1915. 
material does not occur in large enough uniform beds to be used as a building stone, though some small use is made of the irregular boulders in foundations, etc., in construction work. This limestone is of a higher specific gravity and greater density than the usual Floricla limestones and should be of value as a cement ingredient. Though not quite so chemically pure as the Ocala, these same qualities should make it valuable in manufacturing building lime, for it would obviate the "fines" produced by handling the soft Ocala rock in quarries and kilns.

\section{CHATTAHOOCHEE FORMATION}

Name-The varying lithology of the limestones, marls and sandy clays exposed along the Apalachicola river has been very puzzling to geologists studying this area and has led to several different groupings of the formations. The patucity of fossil remains has further added to the difficulty of the problem.

Langdon ${ }^{1}$ first applied the name Chattahoochee to the beds of impure limestone underlain by thinner beds of purer limestone exposed along the Apalachicola river between the towns of Chattahoochee, Ocheesee and River Junction. Foerste ${ }^{2}$ included these same beds under the name "Chattahoochee beds proper." In 1892, Dall ${ }^{3}$ called this for-

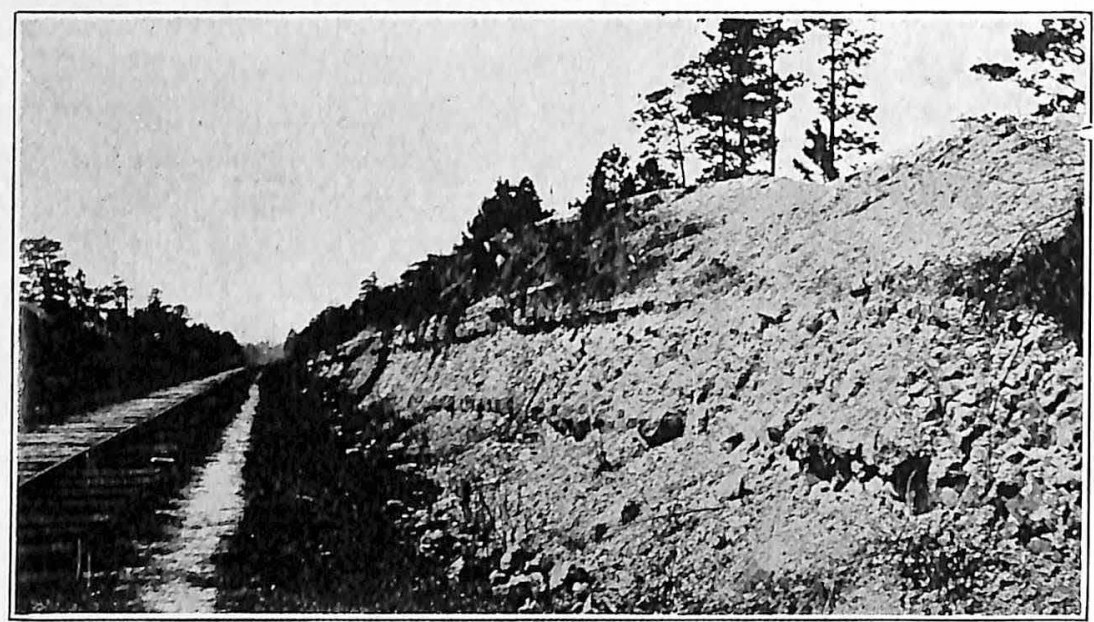

Fig. 16.-Exposure of Chattahoochee limestone on A. C. L. R. R. near River Junction, Gadsden County.

1Some Florida Miocene. Am. Jour. Sci., 3rd ser., vol. 38, pp. 322-324, 1889.

2 Am. Jour. Sci., 3rd ser., vol. 48, pp. 41-54, 1894.

${ }^{3}$ U. S. Geol. Survey Bull. No. 84, p. 87, 1892. 
mation "Ocheesee beds," but in a later paper he notes the absence of exposures at Ocheesee ${ }^{4}$ and uses the names Chattahoochee formation" and Chattahoochee limestone." Matson and Clapp" retained the name Chattahoochee formation and restricted it to "those limestones and marls of northern and western Florida which lie stratigraphically between the limestones of the Vicksburg group and the Chipola Marl member of the Alun Bluff formation." The Chattahoochee has generally been considered of upper Oligocene age, but now is considered lowest Miocene.

In the present discussion the definition of Mlatson and Clapp is followed in the main: $i$. $c$. the name Chat thoochee formation is applied to those beds of argillaceons limestone and mottled sandy calcareous clays as are seen exposed at the type section, the new highway bridge (formerly Chattahoochee ferry-landing) over the Apalachicola river onehalf mile west of the town of Chattahoochee in Gadsden County. The separation of the Ocala limestone from the Marianna and Glendon (Vicksburg group) in northwest Florida has done much to solve the problem, for the earlier geologists included what is now known as Glendon in the Chattahoochee formation and thus gave it a much larger areal distribution than it properly has. Also, the actual contact was never seen. and, since the Glendon is a very pure quite fossiliferous limestone and the Chattahoochee very impure. and sparsely fossiliferous, their true relation was further clouded.

Areal Distribution-The Chattahoochee, as now defined. has a very limited distribution of a few miles in extent along the Apalachicola river in the vicinity of Ocheesee. Rock Bluff. Chattahoochee and perhaps a short distance north of the latter place. No outcrops are to be seen much more than a mile or so from the river in an east-west direction: in all probability the formation has a lenticular outline, which fact coupled with other evidences of lithology, cte., suggests that the Chattahoochee might not be a separate formation as nany have thought, but represent: a local variation of the Chipola marl of the Alum Bluff group, or else is the stratigraphic equivalent of the Tampa.

Thickness and Lithologic description-The type locality of the Chattahoochee formation is at the Chattahoochee Landing on the Apa-

¿Dall, W. H., and Stanley-Brown, Joseph: Cenozoic geology along the Apalachicola River. Bull. Geol. Soc. America, vol. 5, p. $154,1894$.

IIdem, p. 152.

iIdem, p. 155.

TFla. Geol. Survey, 2nd Ann. Report, p. 7t, 1909. 
lachicola river in Gadsclen County. The following generalized section was taken there:

Red, coarse mottled sandy clay, and some small gravel, upper ten to fifteen feet at least, terrace material . . . . . . . . . . . . . . . . 50 feet

Sandy greenish clay somewhat resembling impure fuller's earth; exhibits jointing and conchoidal exfoliation, in places slightly indurated..... 10 feet

Varying lithology, chiefly argillaceous limestone grading upward into sandy. greenish-gray impure calcareous clay ................. 17 feet

Mottled sandy clay, red-purple to yellow and gray. . . . . . . . . . 17 feet

Argillaceous limestone, lower twenty feet is massive light yellow-green, soft and compact, weathers in sloping banks with "mud-crash" appearance. Upper forty-five feet is harder, more brittle, chalk-white, exhibits jointing and weathers in vertical banks with some still harder ledges

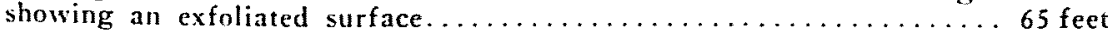

Alluvium of river bottom composed of reddish sands. No exposures of beds beneath this alluvium were seen.

15 feet

$16+$ feet

The thickness of the limestone of the Chattahoochce is therefore sixty-five feet at this location, though the entire formation is one hundred and eight feet at least and probably a little more if the base could be seen. The limestone itself is very impure and variable in composition : analyses show that it carries $14-15$ per cent $\mathrm{CaCO}_{3} ; 9-11$ per cent $\mathrm{MgCO}$ and from (6)-92 per cent $\mathrm{SiO}_{2}$. Iron and alumina are present, usually about five per cent. Where the material has been exposed and weathered, as in the railroarl cut at River Junction, the combined carbonates seldom amount to more than five per cent and the iron and alumina also are greatly reducerl. Silica, as would be expecterl, is very high (90-9.5\%). In a fresh face the limestone has a dull greenish-gray color and is quite "lamp" and soft, though very homogeneous and fine even-grained. Lpon weathering it bleaches to a chalky white and becomes hard and brittle. The limestone is fairly well stratified in hard and soft ledge: and jointed throughout. It fractures in large masses and breaks with sharply demarked but curved faces. The jointing also shows curved outlines, and the faces exposed by this rounded fracturing are stained a deep yellow green-black. Practically no organic remains are seen, but occasionally a poorly preserved cast or small flaw of hazy outline is found in the usually smooth uniform rock.

Sections of outcrops of the Chat ahoochee show a great variation and are difficult to correlate; this rapidly changing lithology is lelieved to 
be due chiefly to the weathering of the underlying impure limestone, in part perhaps to local changes at the time of deposition.

Economic Uses-At one time this limestone was hailed as the world's greatest natural cement, ${ }^{1}$ but it was later found that the deposit was quite variable and unsuitable for this purpose. Since that time practically no use has been made of this soft impure rock except as bulk material in local fills or dam construction.

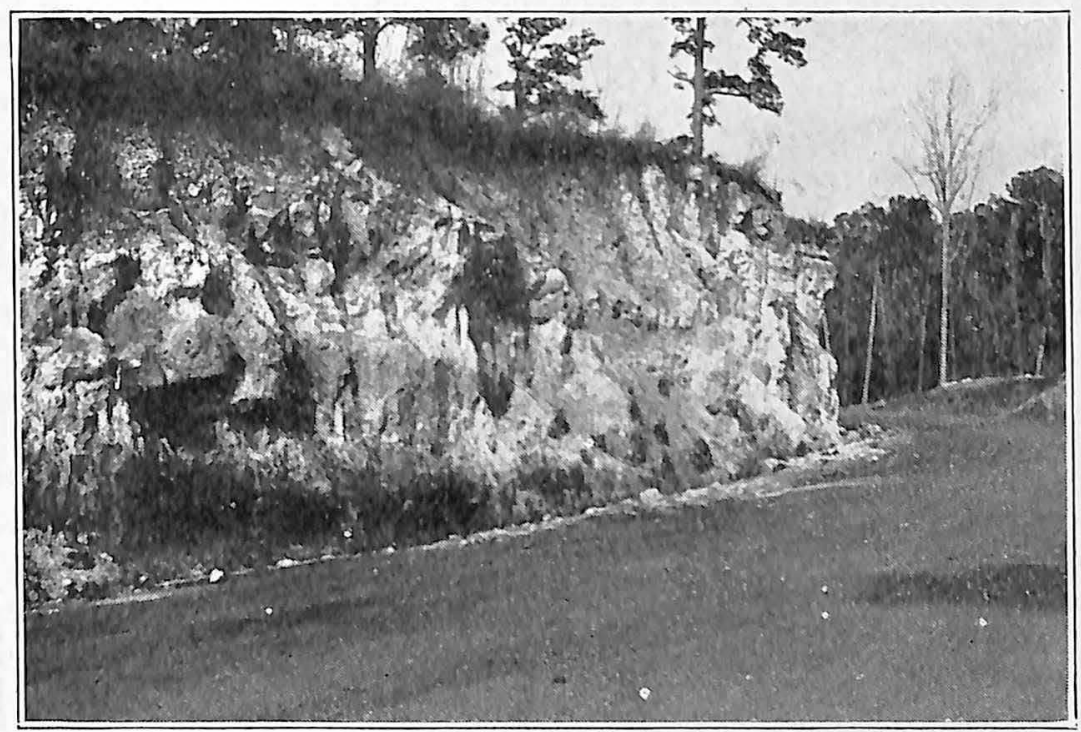

Fig. 16a.-Upper part of Chattahoochee limestone at Victory Bridge (Old Chattahoochee Landing). Photo by N. B. Davis, 1925. 


\section{ALUM BLUFF GROUP'}

The name "Alum Bluff" was first used in 1892 by Dall," who applied it to certain gray sands, in part non-marine, conformably overlying the Chipola marl at Alum Bluff on the Apalachicola river in Liberty County, Florida. The sands were considered lower Miocene in age.

Matson and Clapp in $1909^{3}$ first proposed Alum Bluff as a formational name; they believed it to be of Oligocene age and defined it as follows:

"The name Alum Bluff formation as here used inclucles those beds which belong stratigraphically between either the Chattahoochee formation or the Hawthorne formation and the marls and limestones of Miocene age. This usage differs from that of Dall, who appears to have regarded the Chipola marl and the Alum Bluff as distinct formations. The Alum Bluff formation includes two different, though closely related, members which have been known respectively as the Chipola marl and the Oak Grove sands. To these is added a third member, recently discovered by Vaughan in West Florida, and called the Shoal River marl member, from the stream where it is best exposed."

In 1915 vertebrate fossils were discovered fifteen miles north of Tallahassee at a depth of twenty-five to fifty feet below the surface in gray phosphatic sands of the Alum Bluff formation. E. H. Sellards, at that time State Geologist of Florida, studied these remains and on their evidence reinstated the Alum Bluff in the Miocene. The Alum Bluff is now considered by Miss Gardner as a group and the three former members are raised to formational rank.

${ }^{1}$ The Alum Bluff Group is of the greatest importance to the geologist interested in the stratigraphy of Florida and presents a problem that for the last thirty years, at least, has received much attention by leading paleontologists and stratigraphers. However, it possesses little intrinsic economic value for the purpose of this report and so the group will be treated in the briefest manner. Miss Julia Gardner of the United States Geological Survey has spent several seasons in the field on this problem and has prepared several professional papers covering fully the fauna and stratigraphy. The writer is indebted to her for the following information.

2Dall, W. H.: Bull. U. S. Geol. Survey No. 87, p. 112, 1892.

3Matson, G. C., and Clapp, F. G.: Florida Geol. Survey, 2nd Annual Report, p. $67,1909$.

tSellards, E. H.: Florida Geol. Survey, 8th Annual Report, p. 92, 1916. 


\section{CHIPOLA MARL}

The type locality of the Chipola marl is on the farm of Mr. John McClelland, one mile below Bailey's Ferry on the Chipola river, Calhoun County, Florida; however, the exposure at Alum Bluff was the first to be studied and it along with an exposure at Rock Bluff received the most attention by Langdon, ${ }^{5}$ Dall ${ }^{\circ}$ and other workers. The marl has a large fauna distinct from both the Tampa and Oak Grove and indicates a warmer climate than the two succeeding formations of the group. Its thickness is estimated from one lundred and thirty to one hundred and fifty feet. The Chipola marl includes with its equivalent, limestones, marls, sands, sandstones and fresh-water deposits and has a very wide distribution in northern Florida. The fuller's earth beds in Gadsden and Leon counties are placed in this formation. Marls and some local limestones along the Choctawhatchee river just above Miller's landing and on Holmes creek are of Chipola age, as is the limestone at Sopchoppy in Wakulla County. The stratigraphic relations of the Alum Bluff between the Ocklocknee and Aucilla rivers are not obvious and the limestone there has not been definitely placed, but in the northern parts of Leon and Jefferson counties the red sandy clays are taken as the typical development of the Alum Bluff.

Cooke and Vaughan studied the extent of the Alum Bluff in northern peninsular Floricla and placed much of the old "Hawthorne beds" in this group. Cooke believed that at White Springs the Alum Bluff rests on the Glendon (formerly called Chattahoochee) but farther south overlaps and rests upon the Ocala limestone. The presence of a fuller's earth bed in Manatee County has served as the evidence that beds of the Alum Bluff group underlie much of Hillsborough, Polk and Manatee counties.

\section{OAK GROVE SAND}

The first mention of the Oak Grove is by Johnson:s "The younger Miocene . . . is perfectly and largely developed on the bluffs of the Yellow river, from the Alabana line to Milligan, in Florida, the most northern of these beds being the low shell landing at Oak Grove, six miles south of the line." Dall recognized in the Oak Grove fossils, a fauna distinct from that of the Chipola marl and suggested a correlation

JLangdon, Daniel W., Jr.: Am. Jour. Sci., 3rd ser., vol. 38, p. 322, 1889.

Dall, William Healey: Bull. U. S. Geol. Sur., No. 84, p. 122, 1892.

TCooke, C. Wythe: Unpublished notes.

J Johnson, Lawrence C.: Science, vol. 21, p. 91, 1893. 


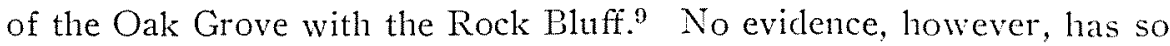
far been offered which has established the presence of the Oak Grove in Florida east of the Choctawhatchee river.

The Oak Grove at the type locality on the Yellow river in Okaloosa County is a compact dark bluish gray sand weathering brown and forming a well-defined platform that stands at ordinary water level about a foot above the river and extends down into the stream for eighteen inches or so. Another exposure is at Tanner's grist mill on Senterfitt creek, two miles northeast of Oak Grove. The marl there is grayish-blue, weathering brown and abundantly fossiliferous, it outcrops eighteen inches to two feet above the water's elge. The marl at that locality according to Vaughan is thirty feet above the Oak Grove exposure and it contains a larger Shoal River element than the Oak Grove, but the relationship to the Oak Grove is considered closer. 'The total thickness of the Oak Grove is a little less than thirty-five feet. Miss Gardner believes the Oak Grove to be the least significant of any of the Alum Bluff formations; its fauna contains only a little more than two hundred species and is intermediate between the Chipola and the Shoal River.

\section{SHOAL RIVER MARL}

In the same report in which he mentions the shell berl at Oak Grove, Johnson ${ }^{10}$ makes note of another fossiliferons deposit which seems to be the locality now known as Shell Bluff on the Shoal River. Vaughan was the first to recognize the Shoal River as a distinct member of the Alum Bluff and gives the following section from Shell Bluff : ${ }^{11}$

8. Gravel-covered slope, gravel elipsoidal, $1 / 2$ inch probably usual length, rarely 1 inch, mostly quartz, in rather coarse red sands.......... 30 feet

7. Gray, finer sand, blotched yellow, decidedly a rgillacecus........... 10 feet

6. Greenish shell marl, matrix arenaceous, fine fossiliferous (Shoal River

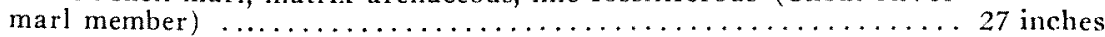

5. Non-fossiliferous, coarser greenish sands, becoming argillaceous at base 3 feet

4. Green clay ...................................... 6 inches

3. Coarser sands, gray, greenish, last $2 \frac{1}{2}$ feet loose, purple and white sands 6 feet

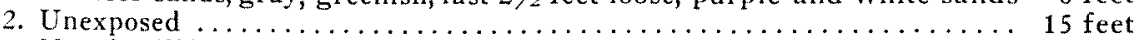

1. Non-fossiliferous green sands, oxidized yellowish on surface (Oak

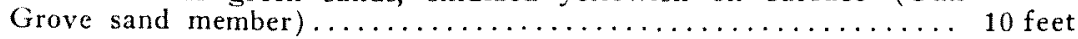

Total of section, about................... 80

Miss Gardner states that bed number one, which Vaughan correlates with the Oak Grove, carries a small but diagnostic Shoal River fama;

9Dall, W. H.: Bull. Geol. Soc. Am., vol. 5, p. 166, 1893.

${ }^{10}$ Johnson, Lawrence C.: Science, vol. 21, p. 91, 1893.

11 Vaughan, T. Wayland, Florida Geol. Survey, 2nd Annual Report, p. 105, 1909. 
it contains a perceptibly larger number of Oak Grove species than the upper, but is referable to the Shoal River. The upper and lower beds at Shell Bluff are much the same lithologically except that the upper bed is more sandy and contains less argillaceous material.

A few outcrops of the Shoal River marl are found near Shell bluft. but no others are known to occur in $1 W$ alton County north of the L. \&. railroad. South of DeFuniak Springs and south of Argyle marls that are considered to represent both the upper and lower beds are exposed in several creeks-Euchee or Bruce creek, Alaqua, Folks, and Whites creek. These outcrops are usually rather thin, about four feet in thickness, and are not exposed for any considerable distances in the creek bottoms. The marl seems to underlie. at a comparatively shallow depth. all this section. for wells thirty or forty feet in depth all pass through it.

The thickness of the Shoal River marl is best seen at Shell Bhuff, where about forty feet of marl and sand are exposed; the marl has a rather limited clistribution as it has not been recognized outside of Walton Comty. No contact has as yet been seen between this marl and the overlying Choctawhatchee.

\section{CHOCTAWHATCHEF, M.ARL}

Namc-In 189.2 Dall referred all the Florida bels of true Miocene age to the Chesapeake group: the subdivisions of this group were the Jacksonville limestone in east Florida and the "Ecphora bed" in the western part of the State. He states that "at Alum Bluff the gronp is represented by what I have termed the Ecphora bed, of gray marl, with over 100 species of fossils, many of which are common to North Carolina, Virginia and Maryland. It has a thickness here of 30 feet or more." Later, Dall" applied the name "aluminous clay" to the 10 to 15 feet of gray unfossiliferous clay overlying the "Ecphora bed" on the Chipola river. Matson and Clapp" in 1909) included both these beds in the Choctawhatchee marl, the name being taken from the Choctawhatchee river. where, in the vicinity of Red Bay, the formation is well exposed.

Stratigraphic Position and Thickness-At Alum Bluff, according to Vaughan, the Choctawhatchee rests uncomformably upon the wavy erosion surface of the secliments of the Alum Bluff group. It is uncon-

1Dall, Wm. H., and Harris, C. D.: Neocene of North America, U. S. Geological Survey, Bull. 8t, pp. 123-12t, 1892.

-Dall, Wm. H., and Stanley-Brown, Joseph : Cenozoic (ieology Along the Apalachicola River. Bull. 5, Geol. Soc. Amer., pp. 168-169, 1894.

:Florida Geol. Survey, 2nd Ann. Report, pp. 11t, 1909. 
formably overlain in turn by unfossiliferous red and yellow sands of probably Pliocene and Pleistocene age. The average thickness of the Choctaw hatchee is probably not much over 15 to :5 fect. though in places it may be over twice that. The following exposed thichnesses were noted: Jackson's Bluff (Ocklocknee river), 10 feet; Rell liay (Comillion property), 19 feet; Darling's Slicle (Chipola river), 31 feet : Four Mile creek, 10 feet, and Econfina creek, 3 miles southeast of betts. 1.5 feet. Miss Julia Gardner gives the formation in the vicinity of Red Bay a total thickness of at least 90 feet.

Lithologic description-The Choctawhatchee is usually greenish gray to light gray in color and consists of varying quantities of quartz. sand and shell; in some places the marl contains a little organic matter and is slightly phosphatic. The shells vary in profusion, at Jackson Bluff they are quite plentiful, well distributed throughout the marl and are large and massive; at Four Mile creek they are practically confined to the lower two feet of the section and here are closely packed : at Darling's Slide the small rather fragile shell, Mactra congesta. forms so per cent of the fossil shell matter and the more massive and larger forms are subordinated. The clay bed which at this last locality occupies the upper eight to twelve feet is light steel gray in color, un fossiliferous and quite plastic; it is also present at Four Mile creek and at Alum Bluff.

Paleontologic description-The Choctawhatchee marl contains an abundant fauna of nearly 200 species. The most numerous is Mactra congesta. Other prominent mollusca are: Ecphora quadricostuta. I cmus rileyi, Arca acutilaqueatum, Cardita arata and various species of Corbula, Pecten, Phacoides, Dentalium, Turritella, etc.

Areal Distribution-The Choctawhatchee is found at the surface in a narrow belt six to twelve miles wide, extendling from south of DeFuniak Springs, Walton County, east and slightly southward into southwest Leon County to about the Ocklocknee river or a little beyond. The formation does not exert any particular topographic influence on the country it underlies on account of its thinness and a heavy mantle of younger sands and clays, but does form the walls and chief support of the narrow strip between stream channels in this area. In the Deadens, Washington County, S. 1s, T. 1 W., R. 13 W., it forms the rims of the shallow sink holes.

Economic Uses-The marl is used locally as a fertilizer or soilcorrective. Its chief value is the lime content; phosphate is only present in very small quantities. 


\section{PLIOCENE SERIES}

CALOOSAHATCHEE MARL.

Nant - The first account of Pliocene beds in Florida was given in Heilprin's report of $188 i^{1}$ He described the shell marls exposed along the Caloosahatchee river and gave them the name "Floridian." The name "Caloosahatchee marl" was applied by Dall to the Pliocene beds along the Caloosahatchee river and the streams entering Charlotte Harbor." He described the shell marls in this area and agreed with Heilprin in referring them to the Pliocene. In subsequent papers ${ }^{3}$ Dall called these marls "Caloosahatchee beds" from the type locality on the river of that name, thus including the "Floridian" of Heilprin. The proximity" and close resemblance of the "Arcadia marl"t of Dall seems to warrant regarding it as a phase of the main formation and it has been included under the name "Caloosahatchee marl" which is retained for the Pliocene marl beds of the Caloosahatchee river and neighboring streams as described by Dall.

Stratigraphic Position and Thickness-The contact of the Caloosahatchee marl with the underlying Miocene has not been seen. Phosphatic marls referred to the Alum Bluff group (Niocene) are known to mnclerlie large areas in the region north of Lake Okeechobee and it may be that they have been eroded from the land now covered by the Caloosahatchec. The consiclerable change of the famma from the Miocene to the P'liocene would seem to indicate an erosion interval. The Caloosahatchee is overlain by variable thicknesses, usually thin, of Pleistocene marls and sands. This contact is sometimes fairly clear and when so shows an unconformity: usually it is obscured due to a reworking of the marl by the advancing Pleistocene sea. The exposed thickness of the Caloosahatchee is seldom over six to eight feet and generally less than this; a consoliclated marl containing. Pliocene fossils was encountered at a depth of nine feet at the St. Lucie lock on Lake Okeechobee and was

'Heilprin, Angelo: Explorations on the West Coast of Florida. Wagner Free Inst. of Science, Trans., vol. 1, pp. 26-33, 1887.

"Dall, Wm. H.: Notes on the Geology of Florida. Am. Jour. Sci., 3rd series, vol. $3+$, p. $169,1887$.

"Dall, Wm. H.: The Neocene of North America, U. S. Geol. Survey Bull. No. 84, pp. 140-1+9, 1892, and Wagner Free Inst. Sci. Trans., vol. 3, pt. 6, pp. 1603-1605, 1893.

${ }^{+}$Dall, Wm. H.: The Neocene of North Anerica, U. S. Geol. Survey Bull. No. 84, pp. 131-132, 1892 . 


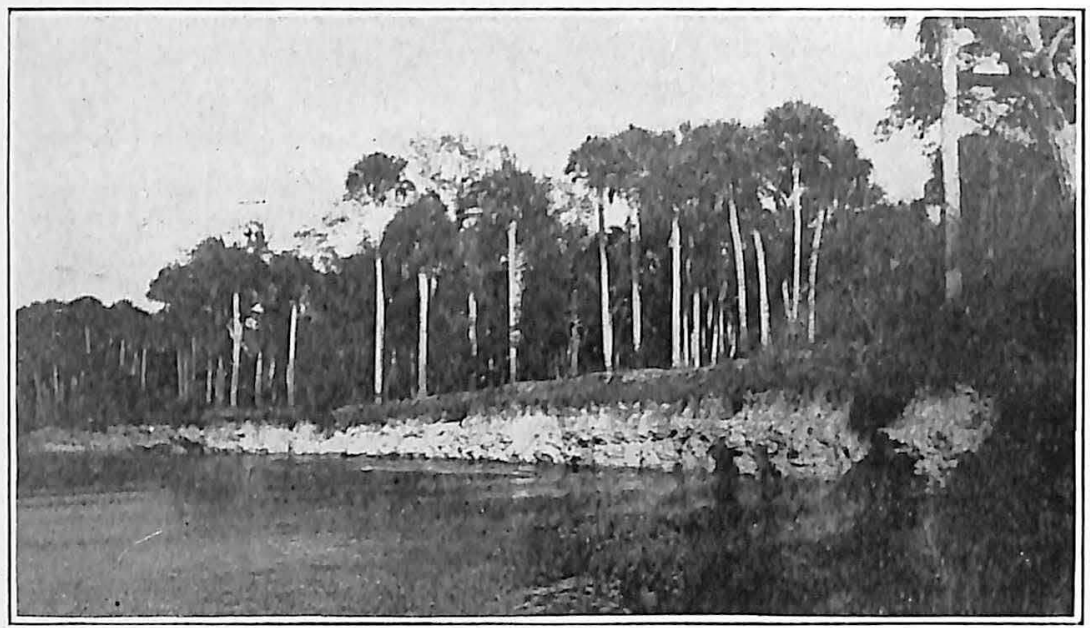

Fig. 17.-Typical exposure of Caloosahatchee beds (Pliocene), Caloosahatchee River, Florida.

dredged to a depth of 18 feet without reaching the base, so that the maximum thickness of the formation may be as much as $25-30$ feet.

Paleontologic description-The total number of species of shells from the Caloosahatchee is listed by Dall ${ }^{5}$ as six hundred and thirty-nine, of which two hundred and fifty-six are peculiar to this formation and three hundred and fourteen are known to be Recent. The fauna is typically that of a shallow tropical sea. Dall recognized the fact that the upper part of the Caloosahatchee contains forms more closely related to present ones than does the lower part, and especially the profusion in the upper beds of Chione cancellata, Planorbis, Physa and other fresh-water or estuarine species.

Lithologic description-The Caloosahatchee consists of a light gray shell marl which is often interbedded with nearly pure sand. The matrix is usually calcareous, made up of fragmental shells, though in places light-colored sand takes their place; even in a calcareous matrix, sand is quite abundant. The formation is remarkable for the state of preservation of the shells as well as for the profusion in which they are found.

5Dall, Wm. H.: Tertiary Fauna of Florida, Wag. Free Inst. Sci., Trans, vol. 3, pt. 6, pp. 1604-1605, 1893. 
The Caloosahatchee if subjected to weathering agencies will form a hard, impure. compact limestone: this has been well shown in digging the St. Lucie Canal, where the material at a depth of 10-15 feet frequently necessitated blasting in order for the dredge to handle it.

Areal Distribution-The farthest northward outcrops of the Caloosahatchee are in Pinellas and Hillsborough comties around Old l'ampa and Hillshorough bays. South of there it immediately underlies a large area consisting of most of Sarasota. DeSoto, Highlands and Glades connties and a small part of northern Charlotte. In all probability this formation unclerlies Lake Okeechobee and most of the Everglades. It has been encountered at a lepth of nine feet at the St. Lucie lock on Lake Okeechobee and probably in other canals on the east side of the lake. but no fossil determinations have been made from these localities.

Economic Uscs-The marl consists chietly of variable quantities of $\mathrm{SiO}:$ and $\mathrm{CaCO}: 3$ with a small percentage of iron and alumina. Its main commercial use is as road material: the consolidated marl phase has been used to construct the new Comners Highway from Okeechobee City to 'Twenty Mile liend on the West Palm Beach Canal. The softer marl is also much used locally for roads. 


\section{NASHUA MARL}

Name-The name "Nashua marl" was proposed by G. C. Matson and F. G. Clapp, ${ }^{1}$ for the beds of Pliocene marl extensively developed in the valley of the St. Johns river; the beds were believed to have certain faunal elements which distinguished them from other Pliocene beds of Florida. They were designated Nashua marl from a locality on the St. Johns river in Putnam County.

Stratigraphic Position and Thickness-It was formerly believed that the Nashua marl might rest unconformably upon the Miocene at DeLand, but further study of the fossil collections shows the absence of diagnostic species of Miocene age. Miocene secliments may be present, but are at a depth and will only be encountered in well borings. White and brown sands of the Pleistocene unconformably overlie the Nashua marl. In addition to the undulating erosion surface of the marl, the abrupt change from the profusely fossiliferous marl to the barren sands emphasizes the break between the two. The thickness of the Nashua marl is usually about four to seven feet, though locally it may be thicker.

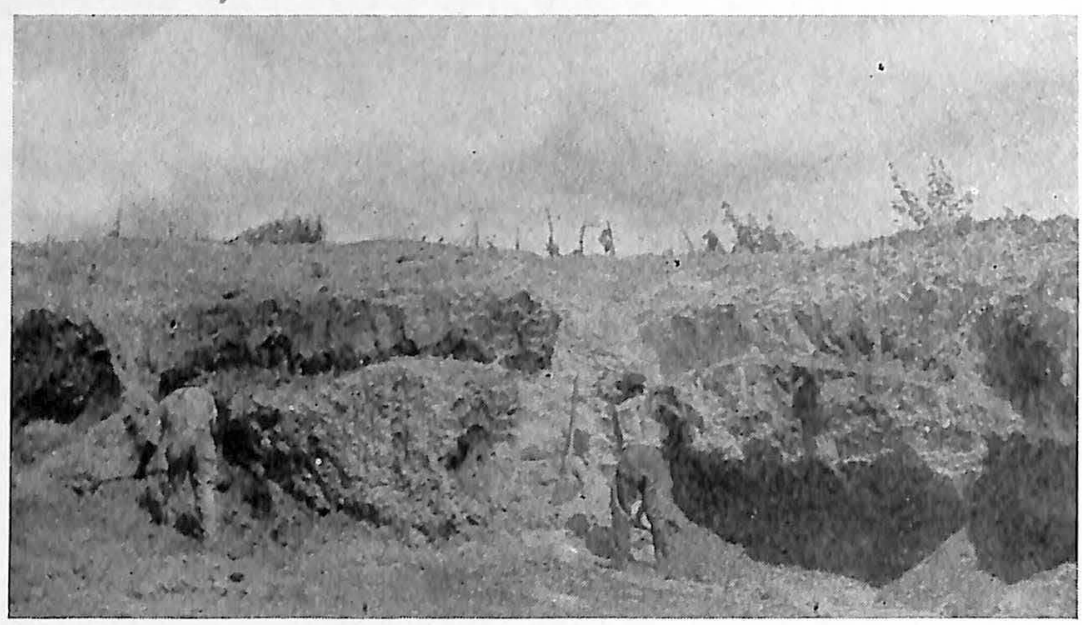

Fig. 18.-Digging Nashua marl for road material, DeLeon Springs, Volusia County.

${ }^{1}$ Matson, G. C., and Clapp, F. G.: Florida Geol. Survey, 2nd Ann. Report, pp. 128-130, 1909. 
In some marl pits west of DeLeon Springs it attains a thickness of ten to eleven feet. Samples from a well drilled at DeLand indicate that the sand and marl of the formation here may be as much as thirty-two feet thick.

Lithologic description-Lithologically the Nashua marl bears a close resemblance to the Caloosahatchee, though it appears to have a slightly more clayey matrix. The matrix is usually light yellow in color and made up of sand with a large amount of finely broken shell particles. Large and massive shells and shell fragments are closely packed but not consoliclated. Toward the southern limits of the formation, around DeLand and Orange City, the material seems more broken up and intimately mixed with larger amounts of yellow clayey sand. To the north the large shells predominate and the matrix is composed of a smaller amount of nearly white-cream colored sand.

Palcontologic description-The fauna of the Nashua marl is very much like that of the Caloosahatchee but has in addition many forms in common with the Waccamaw marl of the Carolinas. Since the original paper by Matson and Clapp, two publications by Mansfield ${ }^{2}$ have added immensely to the paleontologic record of this formation.

Areal Distribution-The Nashua marl is developed, as far as is known, only in the valley of the St. Johns river and for a short distance to the southeast. It underlies the following counties: southeastern Putnam, southwestern Flagler, northeastern Volusia and the narrow eastern edge of Marion and Lake. Wherever found the marl is covered by six to twenty feet of unconsolidated sand. The best exposures are in the marl pits at DeLeon Springs.

Economic Uscs-The marl has been extensively used in Volusia County for road building and has proven highly satisfactory.

2Mansfield, W. C.: Molluscan fauna from the calcareous marls in the vicinity of DeLand, Volusia Co., Florida. Fla. Geol. Survey, 11th Ann. Report, pp. 111$123,1918$.

A Contribution to the Late Tertiary and Quaternary Palentology of Northeastern Florida. Fla. Geol. Survey, 15th Ann. Report, pp. 25-51, 1924. 


\section{PLEISTOCENE SERIES}

During Pleistocene time about half of the present Florida land mass was under water. The area submerged includes parts of Escambia, Santa Rosa, Okaloosa, Walton, Bay, Calhoun, Franklin and Wakulla counties, in the western portion of the State. In the south the margin of the Pleistocene sea extended a little north of Hillsborongh Bay, passing thence southward to the southern end of the divide between the Peace and Kissimmee rivers. It followed the west side of the valley of the latter stream, and probably the land lying east of the St. Johns river was also submerged; certainly the valley of this stream and the whole east coast strip up into Georgia were under water.

In this extensive sea many different types of deposits were laid down; in the cooler waters to the west and north, lying near the older northern land masses sands and some impure clays were the principal deposits, but in the more tropical areas abounding with marine life and farther removed from the older land masses, limestones and marls predominated. Some of these deposits are wholly or in part contemporaneous, while others are clearly older and younger. To accurately differentiate all of them and map their limits is well nigh impossible, for since

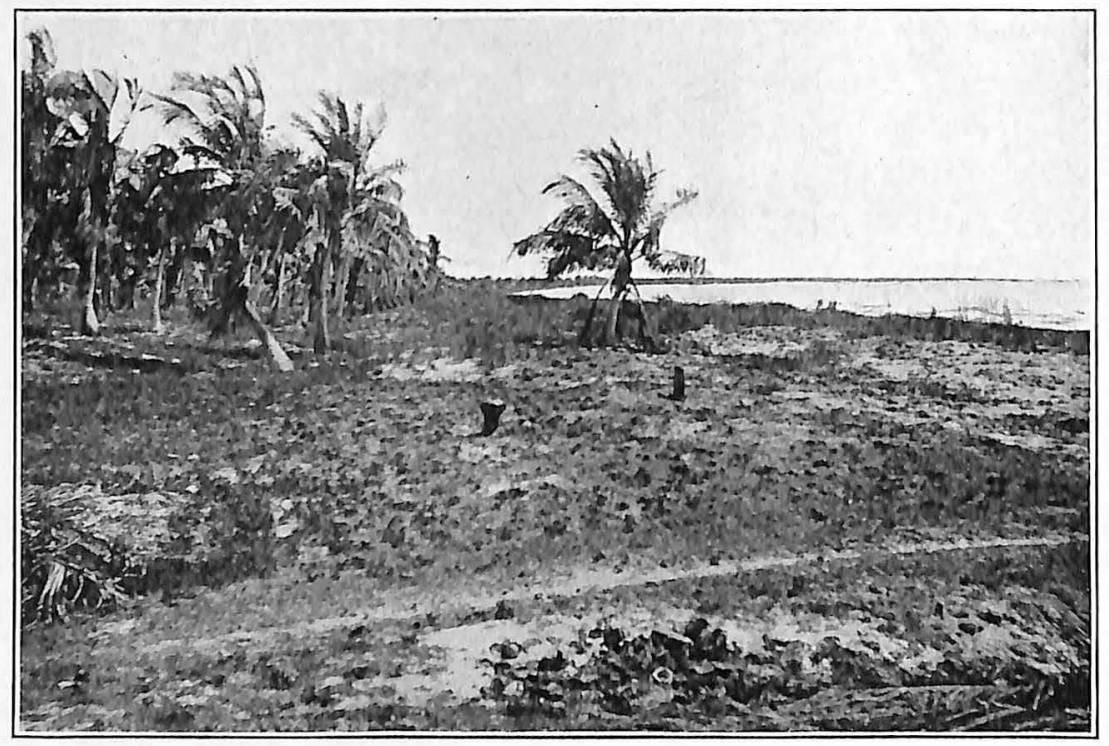

Fig. 19.-Marl and calcareous sand, Cape Sable, Monroe County. 
almost all the fossils range through to the present, the paleontologic evidence is of little value; then, too, the lithology is constantly changing in the shallow sea deposits and would easily lead one astray even if there were frequent exposures, so that only those formations that are a distinct lithologic unit are described in the following pages. Shell marls which can be assigned to this age are abundant over the whole southern area, but no attempt has been made to differentiate or trace them. These marls are known to extend from the vicinity of Daytona, Vero and Fort Pierce southward and westward out into the Everglades. All the drainage canals have cut through variable thicknesses of sandy shell marl between Lake Okeechobee and the coast.

On the west coast similar marls extend from near the ocean front in Manatee and Sarasota counties eastward and southward, underlying all of this part of southern Florida. Along the Caloosahatchee river in the vicinity of Fort Thompson, Sellards ${ }^{1}$ has distinguished three Pleistocene marls including both fresh-water and marine beds, viz: Fort Thompson beds, Coffee Mill Hammock marl, and Lake Flirt marl; none of these is more than two or three feet in thickness, and they cannot be

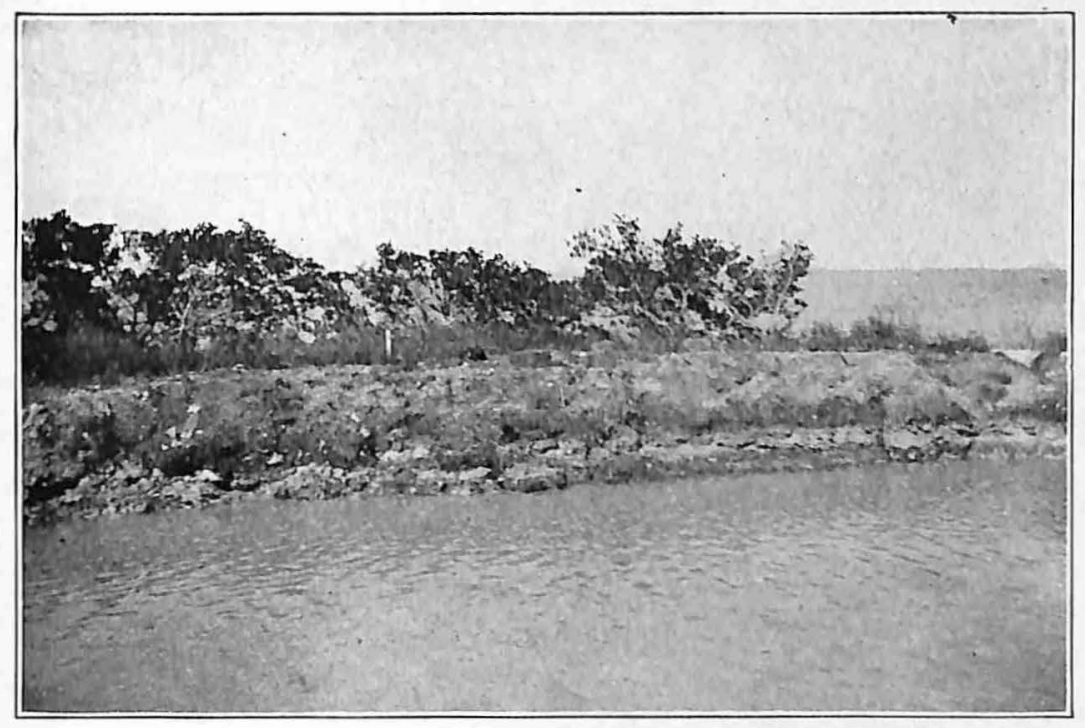

Fig. 20.-Reef Rock overlain by marl, Knights Key, Monroe County.

${ }^{1}$ E. H. Sellards: Geologic Section Across the Everglades, 12th Ann. Report of the Florida Geological Survey, pp. 71-74, 1919. 
definitely traced over any large area, but serve to illustrate the number and rapidly changing character of these Pleistocene sediments.

Predominantly these marls are composed of unconsoliclated light brown to buff yellow sand with variable quantities of shells, but solution and redeposition have been active, so that locally the resultant may be a hard, brittle. impure limestone with many recognizable shells imbedded, attaining a thickness of $t$ to 6 feet, as at Venice in Sarasota County. In many other places the marl has been partially consolidated about a skeleton structure of slightly cemeted shells and amorphous calcium carbonate. In Lee and Collier counties south of Fort Myers this leaching-out process has formed a thin, hard, brittle limestone that is quite pure, homogeneous and free from fossil remains.

All through the Everglades and the southern end of the peninsula thin, hard limestones of varying purity are found. These are believed to be really Pleistocene marls that have undergone redeposition and are so regarded, being classified generally as "marl," since it is impossible to separate and map them and give each an inclividual discussion. Physically, however, they are tough siliceous limestones, almost flint-like in inardness and so tenaceous that a dynamite blast will sometimes fail to shatter them. 


\section{KEY LARGO LIMESTONE}

Nume-The elevated reef that forms the backbone of the main chain of Florida keys has been recognized as made up of coralline material by almost every writer who has described the Keys in any detail. One of the earliest observations is that of Henry Whiting ${ }^{1}$ who called it a coralline limestone. Conrad" visited the Keys in 1842 and was the first to determine the age of the rock as post-Pliocene and to note any evidence of uplift. 'Tuomey followed Conrad's steps eight years later and concurred in his views: "There can be no doubt that this great chain of Keys is clue to the elevation of a vast uneven coral reef whose prominent points rising above the water form the foundation of the Kers, the sands driven up by the waves have done the rest." ${ }^{\prime 3}$ L. Agassiz a year later recognized the coralline character of the reef-rock but denied any evidence of elevation. believing instead that the reef had been built up by the action of waves and wind rolling the coral boulders into their position and cementing them there with limy mul and sand. These views were shared by Hunt and LeConte." In 1883 A. Agassiz published a paper in which he attributed the western growth of the Keys to a return eddy of the Gulf Stream.' Some years later Agassiz revisited the hers and finally changed his opinion and confirmed the conclusions of Tuomey.

In 1906-03 during the construction work of the Florida East Coast Railway the character of the rock from Key Largo to Knights Key was well shown. Borrow pits and dredging exposed the rock both on the Keys and to a depth of 10 feet below sea level in the connecting channels so that Sanford" had excellent opportunity to observe the rock and deter-

1 Whiting, Henry: Cursory remarks on East Florida in 1838. Am. Jour. Sci, 1 st Ser., vol. 35 , pp. $47-64,1838$.

"Conrad, T. A.: Observations on the Geology of a part of East Florida. Am. Jour. Sci., 2nd Ser., vol. 2, pp. 36-48, $18+6$.

"Tuomey, Michael: Notice of the geology of the Florida Keys and of the southern coast of Florida. Am. Jour. Sci., 2nd Ser., vol. 11, pp. 390-394, 1851.

${ }^{4}$ Agassiz, Louis: Florida reef, keys and coast. U. S. Coast Survey Rept. for 1851, Appendix 10, pp. $1+5-160,1852$.

"Hunt, E. B.: On the origin, growth, substructure, and chronology of the Florida reef. U. S. Coast Survey Rept. for 1862, Appendix 25, pp. 241-2+8.

"LeConte, Joseph: On the Agency of the Gulf Stream in the formation of the Peninsula of Florida. Proc. Am. Assoc. Adv. Sci., pt. 2, pp. 103-119, 1857.

'Agassiz, Alexander: The Tortugas and Florida reefs. Mem. Am. Acad., vol. 2, pp. $108-109,1883$.

Agassiz, Alexander: Note on the Florida reef. Am. Jour. Sci, 3rd Ser, vol. 49, pp. 154-155, 1895 .

"Sanford, Samuel: Fla. Geol. Survey, 2nd Ann. Report, 1909, p. 215. 
mine its origin. He gave the formation the name Key Largo limestone from the long series of exposures on that Key.

Stratigraphic Position and Thickness-The Key Largo represents the only truly coralline limestone in Florida, and therefore is distinctly separate from any other formation. In age it is Pleistocene, but its relation to the Miami oolite, also Pleistocene, is uncertain. The Key Largo was built up on the sea bottom from a depth of about 100 feet during a considerable period of time and is probably older, though perhaps in part contemporaneous, than the Miami oolite which is thought to have been formed in the sheltered sea behind this barrier. To the south the Key West oolite seems to overlie the Key Largo, though there is no trace of the latter in a well drilled on Key West. For the thickness of the Key Largo we are entirely dependent upon well records; at Key Vaca reef rock was found fully 100 feet thick; at Indian Key over 130 feet of reef rock is indicated in an account published by Hunt, while at Indian Key Channel a well went through this reef rock to marl at a depth of 40 feet.

Paleontologic description-The Key Largo limestone shows a very small number of fossils recognizable with the naked eye. Coral heads are quite abundant and in many places masses of shell fragments are found. Molluscs, foraminifera, echinoids and coralline algæ are all present. Practically all species are Recent.

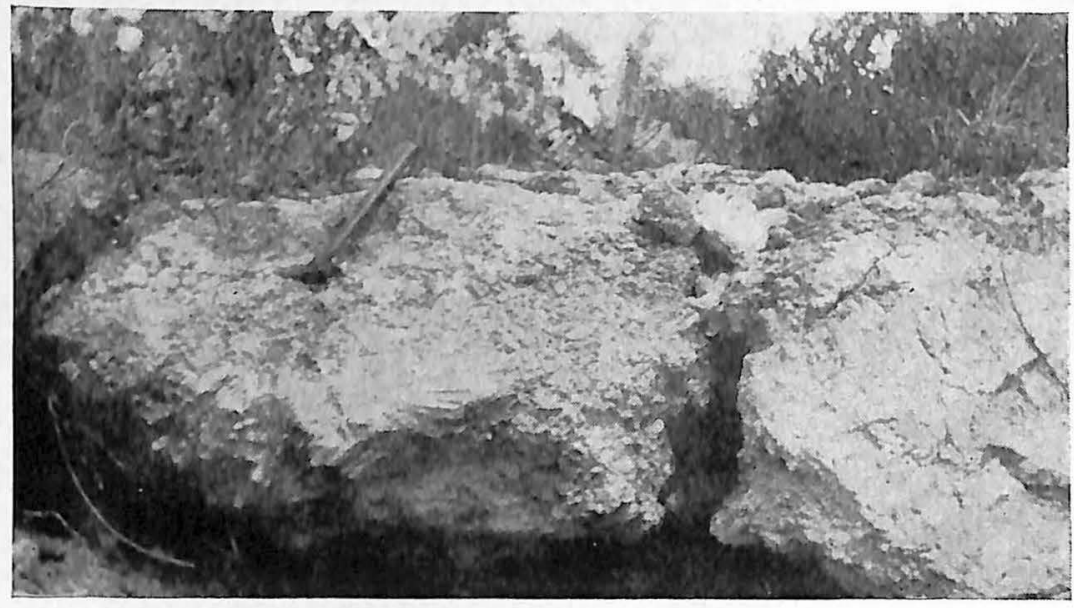

Fig. 21.-Coral head in Key Largo limestone, Marathon Key, Monroe County. 
Lithologic description-The Key Largo limestone is quite variable in appearance and structure. In many places it represents a coral breccia, made up of fragments firmly cemented together. In other places it is a hard. almost semi-crystalline limestone with few or no traces of organic life. Often it is mate up of the standing heads of coral with the interspaces filled with limestone chemically deposited or deposited by coralline alge. Thougl undoubtedly a coral reef, Sanford' estimates that actual corals do not comprise more than one-fourth of the material, the main bulk having been deposited by other processes. ${ }^{10}$ Since the formation of the limestone, solution and redeposition have been very active and the upper two feet or so is cuite hard and indurated; caverns and solution channels everywhere honeycomb the rock. The rock taken as a whole is quite hard. rings under the hammer and breaks with a splintery or conchoidal fracture.

Areal Distribution-The total length of the Pleistocene coral reef is muletermined. That it forms the backbone of the 90-mile stretch from Soldier Key to bahia Honda is undisputed, but its exact occurrence north and west of these two points is not definitely known. The farthest northward growth of Pleistocene reef-building corals recorded is to Hillsborough Inlet, ten miles north of New river. This occurrence was noted in blasting out rock for the canal and as no more coral was encountered to the south along the canal it seems quite possible that it formed an outlier and the main reef did not extend this far north. Some reef rock is exposed on the south shore of Bahia Honda and to the west on end of Big l'ine Key and on one of the New found Harbor Keys.

Economic Uscs-The Key Largo limestone has been chiefly used as railroad ballast in the Overseas extension of the Florida East Coast Railway. On a very limited scale it has been also used as a buileling stone. As Key Largo and the other large Keys nearby are developed, this rock will find increasingly important uses as road material and in the various phases of construction work.

Ibid, p. 186.

1"See pages 50 and 51 . 


\section{MIAMI OOLITE}

Name-Outcrops of oolitic limestone at New river, Miami river, Long Key in the Everglades, and other places were noted by army officers at the time of the Seminole War. The first writer to study the formation was Buckingham Snith, ${ }^{1}$ who noted the molluscan shells in the oolite and determined their age as post-Pliocene.

In 1851 Tuomey ${ }^{2}$ described outcrops of the rock on Miami river. and in the same year Louis Agassiz mentioned them in his account of the Florida reefs. Shaler, ${ }^{4}$ following the views of Agassiz, regarded the oolitic limestone as forming a coral reef and included it, with other rock, in his Miami reef. Alexander Agassiz" in 1875 stated that he believed the limestones at Miami and Coconut Grove were of eolian origin, and in a later paper gave his reasons in detail.' His views were not accepted by Griswold. ${ }^{7}$ Sanford ${ }^{S}$ applied the term Miani oolite to "all the exposures of oolitic limestone on the mainland of southeastern Florida." This designation is followed in the present description.

Stratigraphic Position and Thickness-The relation of the Miami oolite to the other formations in the southern part of the State is not definitely known, as outcrops are obscured by sand and swamp deposits. In age it is probably contemporaneous with the Key West oolite and the upper part of the Key Largo limestone. The formation lies almost flat, with perhaps a gentle dip to the west or southwest. At East Cape Sable oolite is found at a depth of eight feet overlain by a gray marl of late Pleistocene or Recent age. The thickness of the Miami oolite is variable; in the quarry at Naranja ten feet of oolite can be seen with the base unexposed; at the pit of the Ojus Rock Company, Ojus, only eight

1Smith, Buckingham: Report on Reconnaissance of the Everglades, made to the Secretary of the Treasury, June, 1848.

${ }^{2}$ Toumey, Michael: Notice of the Geology of the Florida Keys and of the Southern Coast of Florida. Am. Jour. Sci., 2nd ser., vol. 11, pp. 390-394, 1851.

"Agassiz, Louis: Florida Reefs, Keys, and Coast. U. S. Coast Survey Rept. for 1851 , appendix 10 , pp. $145-160,1852$.

${ }^{4}$ Shaler, N. S.: The topography of Florida. Bull. Mus. Comp. Zool., Harvard Coll., vol. 16, No. 7, p. 143, 1890.

Agassiz, Alexander: Note on Florida Reef. Am. Jour. Sci., 3rd ser,, vol. 49, p. 154-155, 1895.

'Agassiz, Alexander: The elevated reef of Florida. Bull. Mus. Comp. Zool, Harvard Coll., vol. 28 , No. 2, pp. 29-62, 1896.

${ }^{T}$ Griswold, L. S.: Notes on the Geology of Southern Florida. Bull. Mus. Comp. Zool., Harvard Coll., vol. 28, No. 2, pp. 52-59, 1896.

SSanford, Samuel: Geology of Southern Florida. 2nd Ann. Report Fla. Geol. Survey, p. 211, 1909. 
feet of oolite is exposed above water level, though the rock is dredged to a depth of 21 feet, making a total depth here of 29 feet. The following figures are the reports of well drillers upon the thickness of the oolite: At Fort Lauderdale, 12 feet; at Dania, 40 feet; at Miami, 30 feet; other wells have been sunk into the formation to the depths given but have not yet reached the base: Naranja, 30 feet; Ojus, 38 feet: Homestead, 66 feet. Making due allowance for the scantiness of the data and the unreliability of well records, these figures would indicate that the oolite has a maximum thickness of less than 75 feet along the coast in the type area and south, thinning out to the north and inland.

Lithologic description-The typical rock as seen in quarries in the vicinity of Miami is a soft, white, pure $(95 \% \mathrm{CaCO} 3)$ oolitic limestone with occasional irregular layers of calcite. The rock usually shows thin

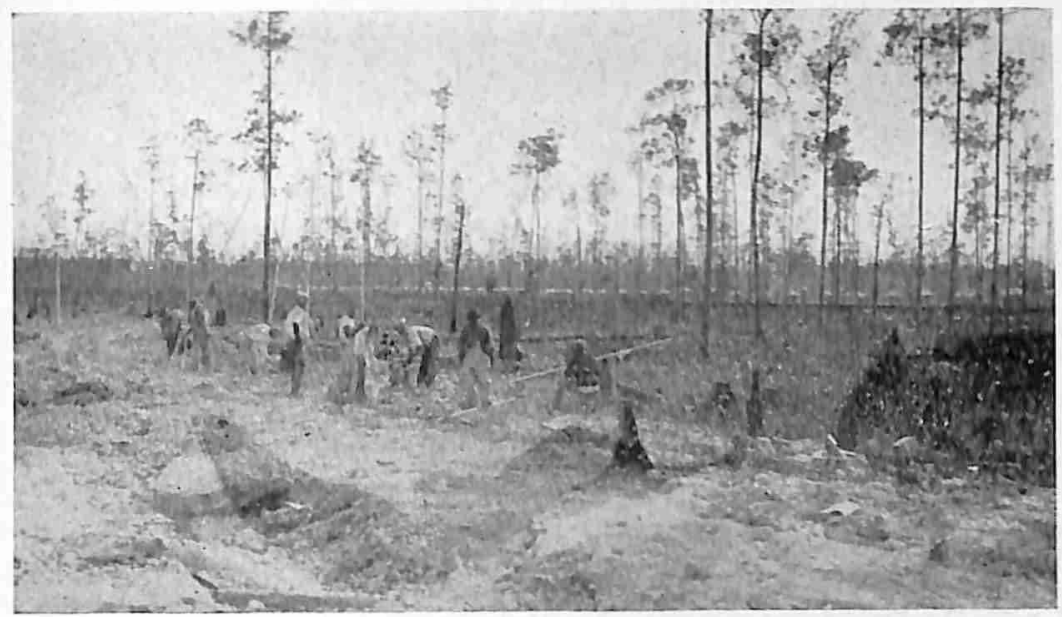

Fig. 22.-Drilling dynamite holes in Miami oolite, Naranja pit of Ojus Rock Company, Dade County.

cross bedding indicative of rapidly shifting currents at the time of deposition. Frequently, subangular-rounded grains of sand are mixed with the limestone. This is particularly true toward the northern boundaries of the formation. In many places whole lenses or pockets of white sand occur. This is especially noticeable in the vicinity of Ojus where the rock has been subjected to weathering and altered from a soft homogeneous phase to a hard, jagged cavernous rock mixed with much white sand. Most of the sand here is in a free state, but a considerable portion has 
been incorporated into the semicrystalline rock. The rock hardens upon exposure to air and rain and weathers into jagged knobs and lumps. It makes excellent road material and is also used locally as a building stone, though its irregular fracture planes make it difficult to shape, especially when indurated.

Paleontologic description-Though the formation is distinctly a fossiliferous limestone, well preserved fossils are not at all abundant throughout the main body of the rock. Chione cancellata and Ostrea $s p$. are the most common; other molluscs, gastropods and several nonreef building corals are present. Small heads of Siderastrca are fairly abundant in places. Practically all species found are Recent.

Areal Distribution-The Miami oolite extends as a rather narrow strip along the coast of southeastern Florida from the vicinity of Boynton down to the end of the mainland. The width of the formation varies considerably; at Fort Lauderdale and to the north the typical oolite extends only about six miles inland and then passes into white quartz sand and sandy limestone which may be the stratigraphic equivalent of the oolite, which in this area contains much sand and sandy lenses. South of Fort Lauderdale the formation is wider, extending perhaps

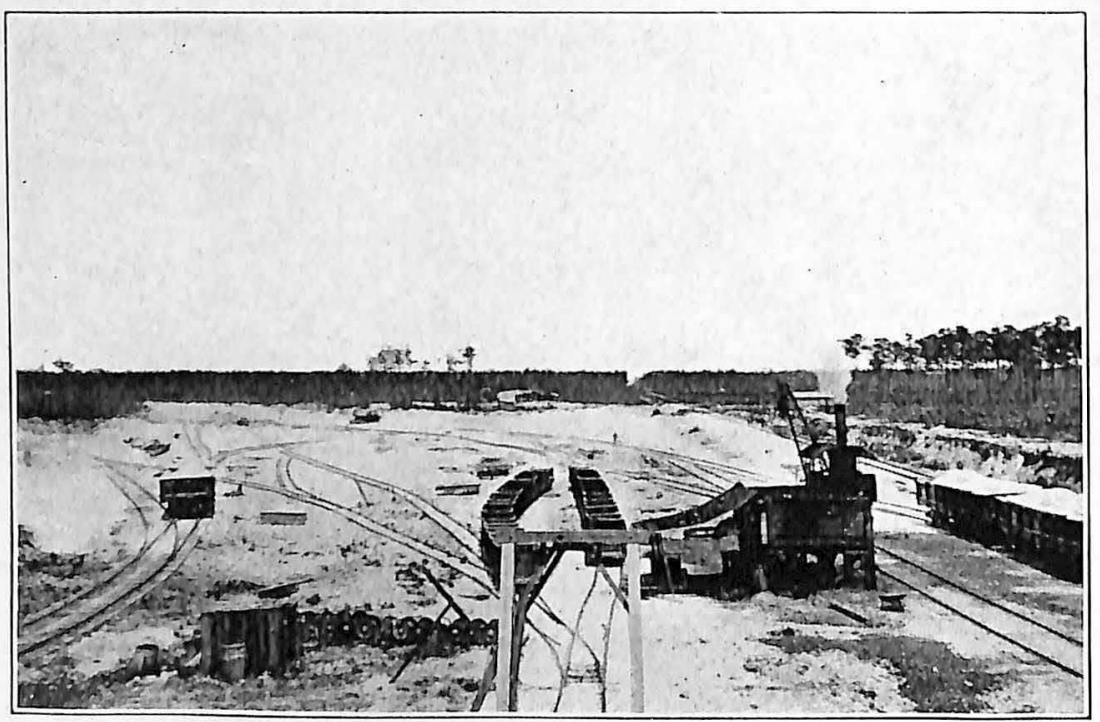

Fig. 23.-Quarry in Miami oolite, Dade County. 
twenty to thirty miles inland: outcrops here are obscured by the swamp deposits and vegetation of the Everglades. In the extreme south and west, the oolite has been traced to within a mile and a half of the settlement of Flamingo near East Cape Sable where it is found at a depth of 6 to 8 feet. If outcrops could be seen the formation would probably cover the whole southern end of the mainland, the outcrop line then sloping sharply up toward Boynton.

Origin-There have been many opinions regarding the formation of oolites and all aspects of the problem are not yet definitely known, though work on the precipitation of calcium carbonate from sea water has advancerl our knowledge greatly in the last few years. Only a brief survey of the various opinions will be given here.

Two theories have been proposed for the origin of the Florida oolites: First, that of Alexander Agassiz. ${ }^{1}$ who considered that the deposits were of aolian origin and were made in a "hunge shallow sink": and, second, that of Louis Agassiz," who considered them of aqueous origin, "formed by deposits of limestone mud." Various other older geologists held opinions that were modifications of L. Agassiz, chief among whom was Shaler," who consiclered the oolite a coral reef rock; in this he was mistaken, but his opinion is to be attributed to the prevailing trend of thought at that time, which, following LeConte's theory, regarded all limestone in south Florida as formed through the agency of corals. The latest opinions are those of Vaughan and Sanford, who regard the oolites as laid down in tropical seas. Vaughant believes they were laid down probably behind a seaward barrier. He states:

The reasons for this opinion are that numerous marine fossils are found in the oolitic material, the two valves of bivalve molluscs frequently in place, showing no damage by attrition, and fossils, corals, which exhibit no indication of having been rolled or waterworn, are found. The marine fossils found in the oolite had evidently lived in the water during the formation of the oolite. On the surface of Big Pine Key original mud cracks formed by desiccation were observed and photographed.

\section{Sanford's" account is quite similar:}

The characteristics of the calcareous sands and marls accumulating about the keys and in the Bay of Florida, and the distribution, topographic relief, bedding,

1Agassiz, Alexander: The Elevated Reef of Florida. Mus. Comp. Zool. Bull., vol. 27, pp. 29-62, 1896.

ZAgassiz, Louis: Mus. Comp. Zool., Mem., vol. 7, p. 19, 1880.

"Shaler, N. S.: Topography of Florida. Mus. Comp. Zool. Bull., vol. 16, p. 143,1890 .

'Vaughan, T. W.: Carnegie Inst., Wash., Year Book No. 7, p. 133, 1909.

sSanford, Samuel : Florida Geol. Surv., 2nd Ann. Report, p. 222, 1909. 
contained fossils and structure of the Key West and Miami oolites indicate that the latter were limy muds, with a varying proportion of lime sand and a little quartz sand, which accumulated on the bottom of shallow bays or lagoons, where in places the water was relatively still, in places agitated by waves and currents strong enough to build up and level off banks and bars.

The conclusions of the last two writers show that beyond a doubt the oolites are formed in a shallow tropical sea, on flats crossed by moderate variable currents. The exact method of formation of the grains seems to be due to calcium carbonate precipitated either organically or inorganically from sea water. As these finely divicled particles settle down in the sea some of them crystallize in little needles or balls of aragonite $\left(\mathrm{CaCO}_{3}\right)$ and around these as nuclei other particles gather, formung the tiny concentric nodules that in great masses form the limestone around Miami and on Key West. Some writers have claimed that the nucleus of an oolite is a grain of sand or a small bit of shell. This may be true in some instances, but since oolites cán be reproduced without either of these artificial nuclei present it seems that the usual mode of formation is that first mentioned.

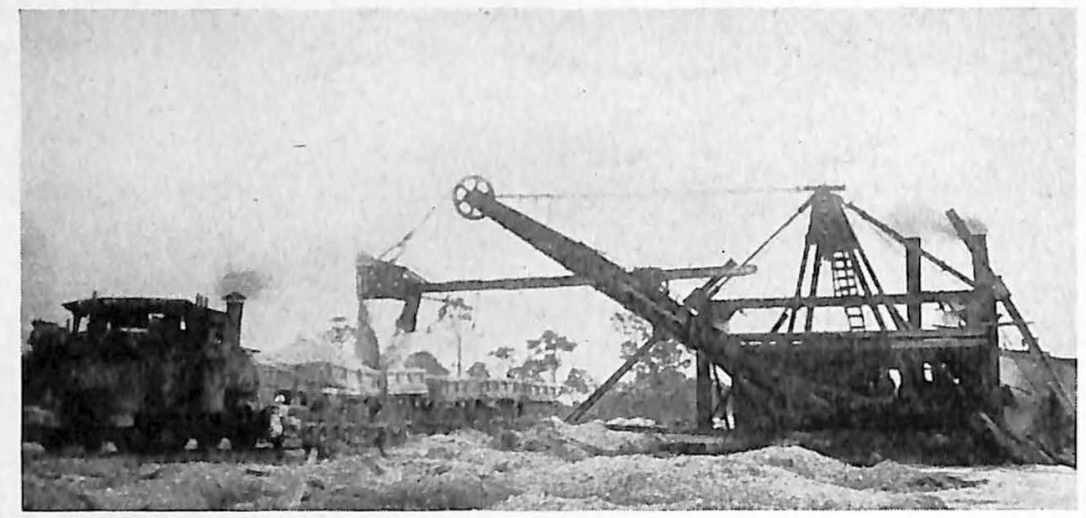

Fig. 24.-Dredging the Miami oolite in Maule Ojus Rock Company pit, Ojus, Dade County.

The large quantity of white quartz sand found in the northern limits of the Miami oolite probably led early investigators to regard the presence of these grains as necessary to the formation of oolites, but analyses of oolitic limestones from Naranja (twenty-five miles southwest of Miami) and Key West show only $1.86 \%$ and $.50 \%$ of silica, respectively. It seems highly probable that some of this small silica 
content must be in the form of pure sand grains, so that the amount that has served as the nuclei for oolites must be extremely small and is further evidence that this cannot be regarded as the common mode of formation.

Economic Uses-There is a large demand for the Miami oolite as railroad ballast and road material, though it also has been used in construction work. Several of the large buildings in Miami are built from this rock as well as numerous walls and some of the sea walls and jetties. In the last few years, owing to the building boom at Coral Gables and other suburbs about Miami, this native stone has been extensively employed for all manner of architectural purposes.

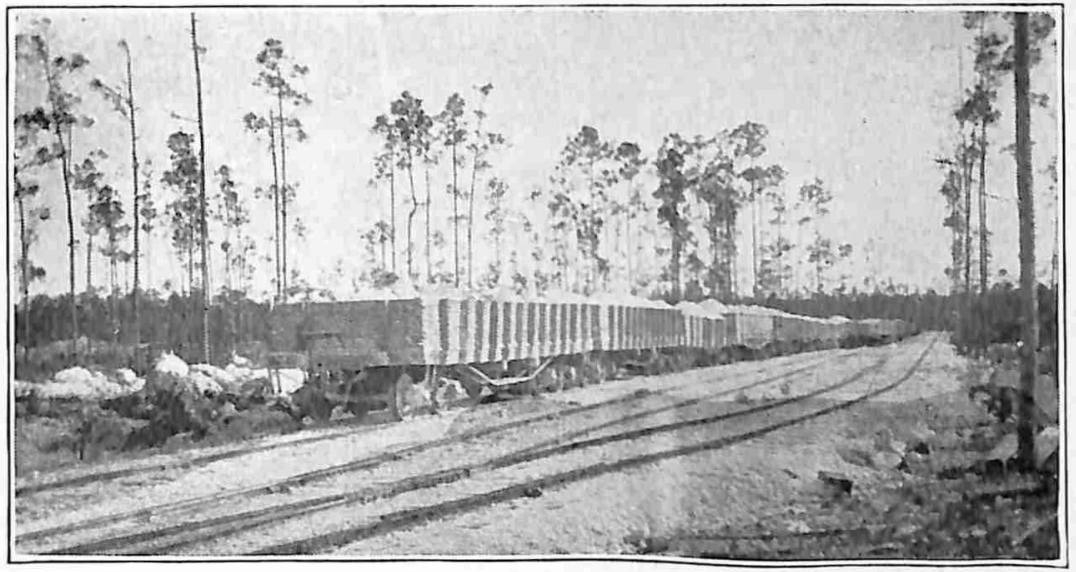

Fig. 24a.-Train load of road material (Miami oolite). Ojus Rock Co. pit, Naranja, Dade County. 


\section{KEY WEST OOLITE}

Nanc-The first distinctive reference to the rock here designated Key West oolite appears to be that of G. W. Featherstonlaugh, who at a meeting of the New York Lyceum of Natural History in September, 1828, exhibited samples of oolite from Key West. ${ }^{1}$

Conrad,, 2 on his visit to the Keys in $18+\%$, suggested the post-Pliocene age of the rock. Tromey," in 1850, noted the oolite and compared it to the recent deposits along the Keys, and L. Agassiz," in 1852, described the rock in some detail. Hunt" believed that the oolite had formed from the consolidation of limy material similar to that accumulating about the Keys, and A. Agassiz thought that the Key West oolite, like the Miani oolite, had an eolian origin. Sanford ${ }^{6}$ applied the name to "all the oolite outcropping on the Keys south of Florida Bay."

Stratigraphic Position and Thickness-On the sonth side of Big Pine Key and on one or two of the smaller keys in this vicinity the Key West oolite apparently overlies the Key Largo limestone. though no definite contact is observable. The relation of the Key West oolite to the Miami or to the marls exposed on the sonthwestern mainland, can not be determined. The thickness of the oolite is unknown. Many wells have been drilled at Key West, but only in a few instances have samples been taken and logs prepared; even then there is some doubt as to the care with which the samples were collected and labeled so that only a general idea of the thickness can be gotten. From one of these logs E. O. Hovey determined the thickness as only $25-50$ feet; a well drilled by J. T. Brown for S. O. Johnson in this same vicinity went through solid oolite to a depth of 100 feet. Another well is reported as having been sunk 65 feet into rock of similar character as that at the surface. The last two figures probably approach more nearly the correct thickness.

Lithologic description-The Key West is typically a soft, white, pure fossiliferous oolitic limestone. It very closely resembles the Miami but nowhere contains quartz sand grains as the latter frequently does. The

\footnotetext{
${ }^{1}$ Am. Jour. Sci., 1st ser, vol. 16, p. 206, 1829.

${ }^{2}$ Conrad, T. A.: Observations on the Geology of a part of the coast of East Florida. Am. Jour. Sci., 2nd ser., vol. 2, pp. 36-48, 1841.

"Tuomey, Michael: On the Geology of the Florida Keys. Am. Jour. Sci., 2nd ser., vol. 11, p. $390,1851$.

${ }^{4}$ Agassiz, Louis: Florida reefs, Keys and Coast. Rept. U. S. Coast Survey for 1851, Appendix 10, 1852, pp. 145-160.

'Sanford, Samuel: Fla. Geol. Survey, 2nd Ann. Report, p. 219, 1909.
} 
Key West oolite seems of slightly finer grain and more uniform texture, but in general the two could not be distinguished in hand samples. The formation exhibits cross-beddling though not so pronounced as in the Miami oolite: it weathers easily, but does not form the rough, jagged surface as in the pinelands about Miami. Characteristic of the Key West surface are the small vertical channels, often connecting with underground water channels: in general the land surface underlain by the Key West oolite is smooth and level. Often the oolite is covered with a thin marl or, less often, beach sand; in many places the formation is exposed clown to the water edge.

Palcontologic description-The abundant marine fossils of the oolite are mostly molluses and foraminifera with a few corals (non-reef-building) and echinoderms. Nany of the molluscan forms are very slightly worn and have both valves closed, indicative of a quiet sea at the time of their cleposition. All forms are Recent.

Areal Distribution-The Key West oolite is limited to the group of keys lying to the west of Marathon Key. These include Bahia Honda, Big Pine, Saddle Bunch, Key West and many other smaller keys between Key West and Bahia Honda.

Economic Uscs-The Key West oolite has been used locally for building purposes, walls, foundations and, on a small scale, entire buildings have been constructed from it. 


\section{COQUINA}

In a strict sense the term "coquina" should only be applied to the pure shell rock on Anastasia Island; the material there is entirely composed of small, clean shells and fragments of larger ones, rounded by wave action but still retaining much of their natural color. However, in this report the term will be used to designate all deposits of ceniented shell fragments and quartz sand that can be seen at many localities near the present ocean shore on the east coast of Florida. Somewhat similar deposits occur also on the west coast near Sarasota and southward, but are thinner, less persistent and not used commercially, so the discussion is limited to the east coast occurrences. All gradations between the

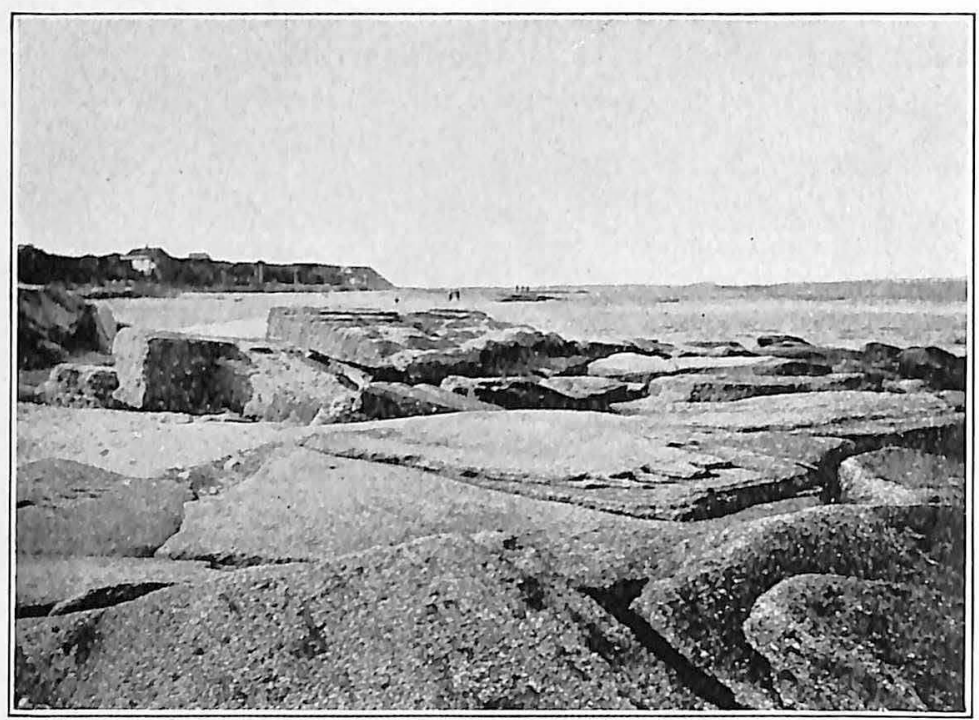

Fig. 25.-Outcrop of Coquina Rock near Lighthouse, Anastasia Island, opposite St. Augustine, St. Johns County.

pure shell rock and material made up predominantly of quartz. sand grains can be seen on the East Coast in a narrow strip along the ocean front extending from Anastasia Island to the vicinity of Delray. This coquina strip is not very wide (at Anastasia it is less than 200 yards), nor is it at all continuous. In thickness, too, it is quite variable. On Anastasia Island an old Spanish well 50 feet deep, shows coquina clear to the bottom. At Flagler Beach and Indian River City workings in 
the coquina attain clepths of 18 and 14 feet, respectively, without reaching the bottom of the deposits; the pits at Volusia show the rock with a maximum thickness of 12 feet resting on sand or unconsolidated sand and shell; a road cut on the golf links at Palm Beach shows 23 feet of very sandy coquina with the base still unexposed.

There are three chief phases to the rock with many intergradations; the first is the coquina as seen in the center of Anastasia Island and at Indian River City; at these places there is no sand or any other foreign material mixed with the shell ; the shells or shell fragments are about the size of a thumbnail and smaller, usually unconsolidated but with hard ledges (near the top of the deposit) of firmly cemented shells.

A second phase of the coquina has given rise to considerable commercial development at Flagler Beach, Volusia and Eau Gallie. At these localities the shells have been finely broken up by the pounding waves on the ancient beach where they were deposited, and subsequently have been closely cemented to form a very hard compact rock. Ordinarily the shells have been crushed beyond all recognition, but occasionally small layers of nearly complete shells occur. The deposits of this firmly cemented, badly broken shell are from 5 to 12 feet thick and occur only over comparatively small areas, 15 to 30 acres. The rock is very durable and is extensively used along the east coast as a building stone. It has also been found to make an excellent base for asphalt roads. Many: of the streets of Daytona, Daytona Beach, Ormond, Melbourne, Melbourne Beach, Cocoa Beach and Eau Gallie are constructed of this type of coquina. This type of coquina is also seen near the lighthouse on Anastasia Island and was used by the Spaniards in constructing Fort Marion and other early buildings in St. Augustine; it is the popularly known "first building stone used in America." This coquina is thicker here than at the other localities to the south.

The third phase is well exhibited in the Blowing Rocks just north of Jupiter Inlet and in the rock that forms the backbone of Palm Beach and the islands in Lake Worth. This material is composed of finely broken up shells and a large quantity of quartz sand grains; the calcium carbonate of the shells seems to act as the chief cementing agent. Strictly speaking it is more of a calcareous sandstone than a sandy coquina. This phase extends at intervals from north of Jupiter to Delray. At Mosquito Inlet, three miles north of New Smyrna, about eight feet of coquina is exposed on the south bank. This material is composed of 


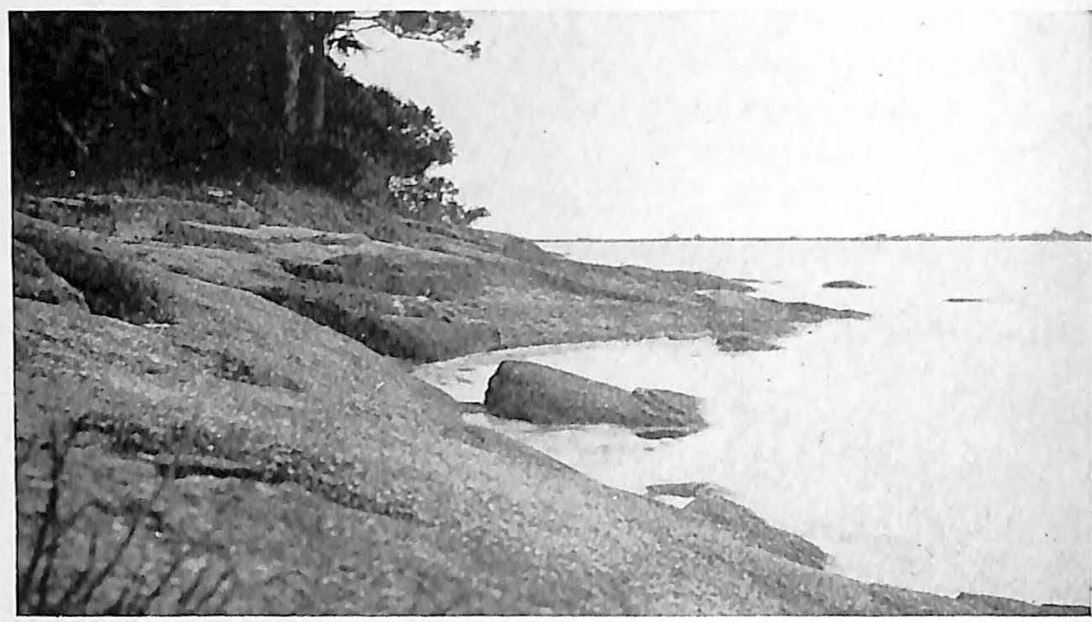

Fig. 26.-Coquina on shore of Mosquito Lagoon, north of New Smyrna, Volusia County.

loose, very slightly consolidated shells, but the shells are covered with a fine white clayey material instead of being clean and pure. The exposure south of Indian River City is mostly loose or very slightly consolidated clean shell with some hard ledges in the upper five feet. The Flagler Beach occurrence consists of about 10 to 12 feet of hard compact building coquina resting on 3 to 5 feet of loose clean shell; below this the loose shell is "rotten" or contains dirt and organic matter.

All the coquina was formed under similar conditions, namely, on an old sea beach, but due to changing local conditions of the power of the waves or direction of currents, some cleposits contain more finely broken shell or more sand than do others. In general, deposits north of Jupiter do not contain a great deal of sand.

The consolidation of the beds and cementing of the shells by their own calcium carbonate took place after the old sea beach had been elevated to, or a little above, its present position. The species of shells represented in the coquina beds are almost all living today and are being thrown up on present beaches in coquina now forming. The shells in the coquina beds are the most recent fossils and still retain a good deal of their natural color which adds much to the beauty of this pectliar rock.

Economic Uses-The unconsolidated coquina is used as a concrete aggregate, and as a topping for roads after being mixed with asphalt or 
tar. Probably the most important use is as a facing in artificial coquina building blocks and building ornaments, as cornice blocks, garden bowls, etc. These articles are made of cement with the coquina used instead of coarse sand and are faced with a $1 / 2$ to 1 -inch layer of pure, fresh, loose shelled coquina. The more compact, closer cemented rock is widely used as road material and as a building stone.

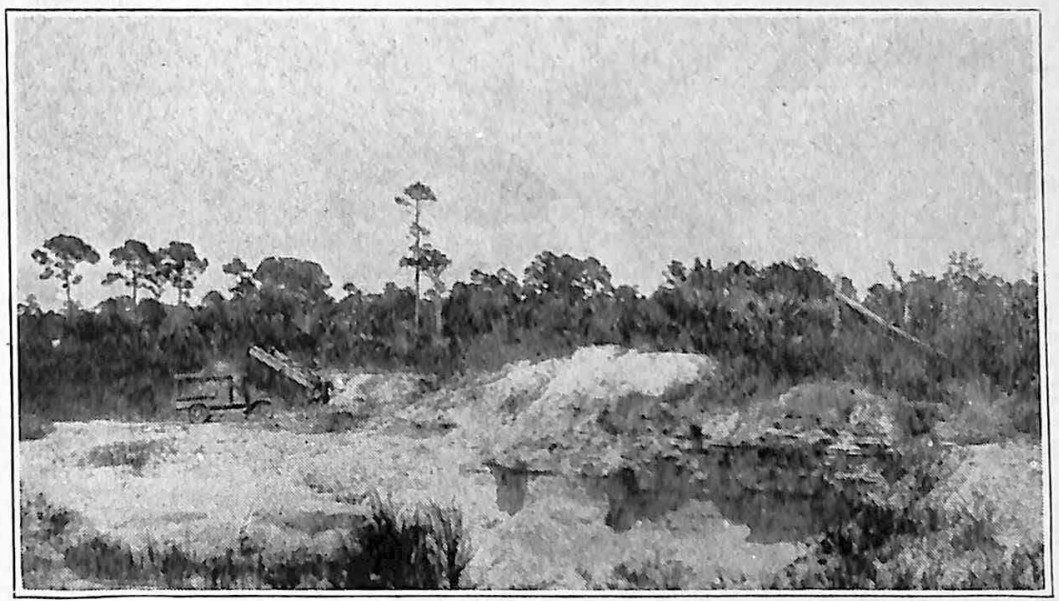

Fig. 26a.-Coquina in old pit near Indian River City, Brevard County. 



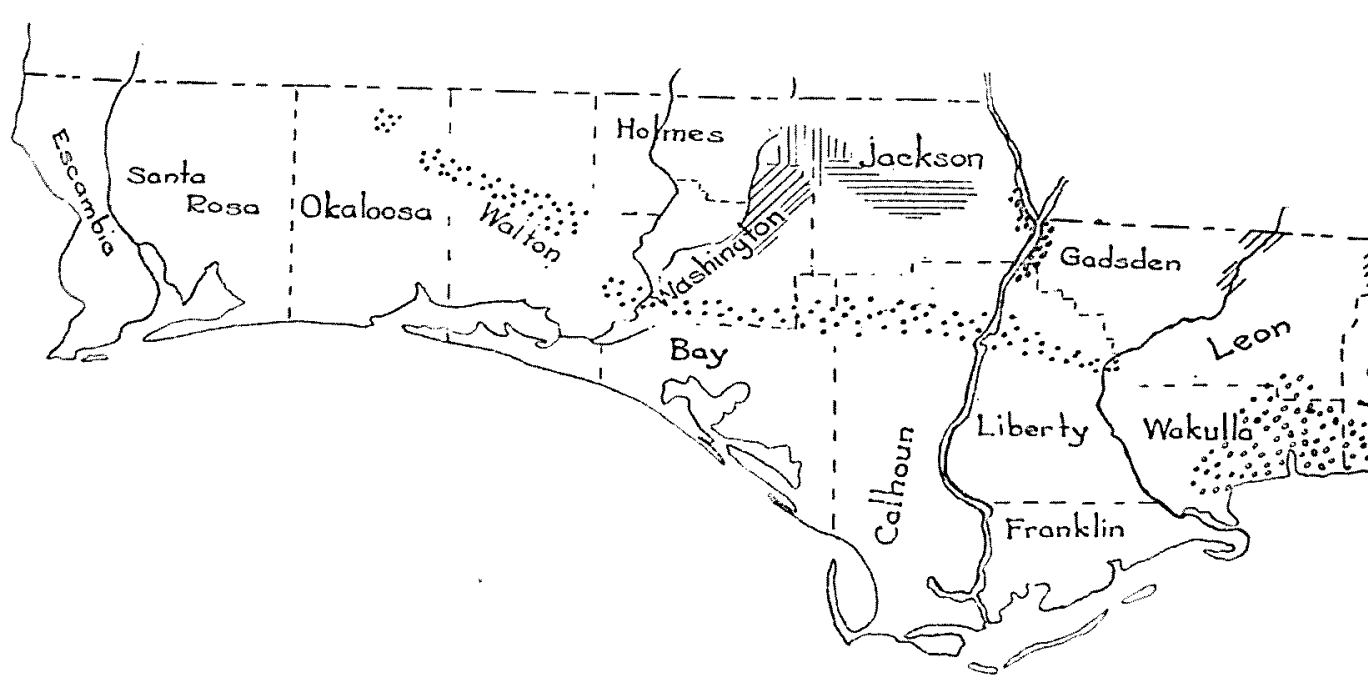

QEOROIA

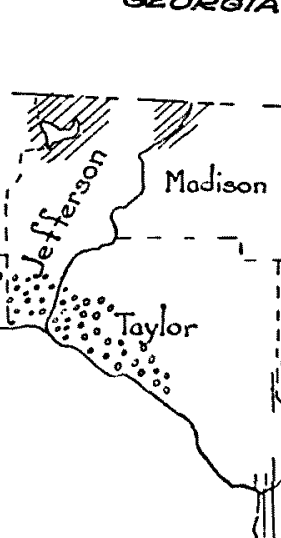

\section{MAP \\ of \\ FLORIDA}

SHOWING DISTRIBUTION OF WORKABLE LIMESTONE

scale of Miles.

$0.10 \quad 20 \quad 30 \quad 40 \quad 50 \quad 60 \quad 70$

\section{LEGEND}

[E. COQUINA

[O:- MARLS (Undifferentiated)

WIIIIX GLENDON LINESTONE

E

MARIANNA

OCALA

TAMPA

MIAMI

5

ALL OTMER LIMESTONES.

NOTE:-

NO ATTEMPT HAS BEEN MADE IN THS MAO TO SHOW INDIVIDUAL DEPOSITS; IT MERELY SHOWY THE GENERAL AREAS WHERE THE REPRESEMTED FORMATION OUTCROPS OR LIES SUFFICIENTLY NEAR THE SURFACE TO BE WUFFICIENTL

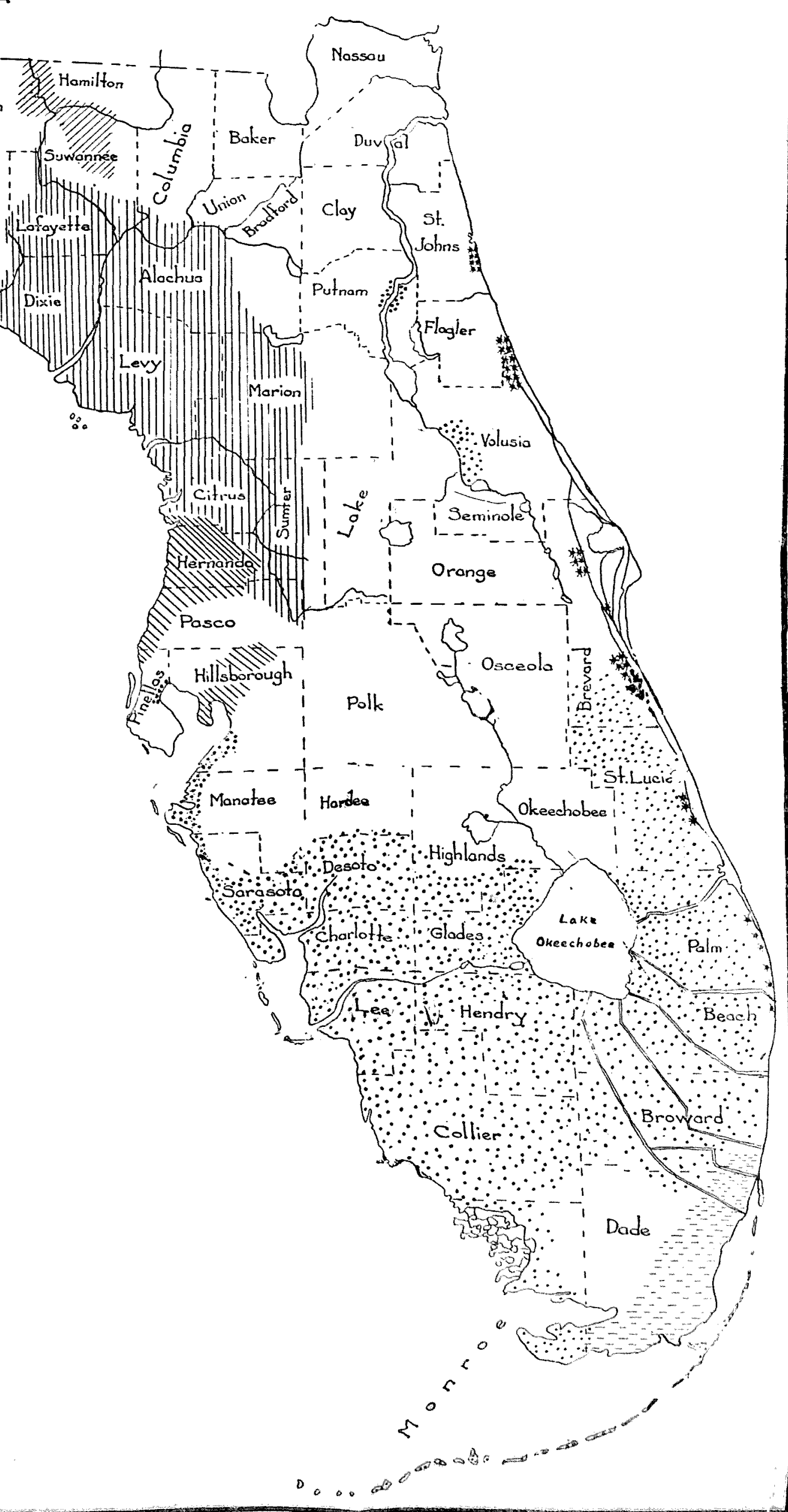





\section{DESCRIPTION OF DEPOSITS BY COUN'TIES}

\section{AI.ACHUA COUNTY}

Alacluna County, lying in the north central portion of the peninstula, is underlain for the most part by the Ocala limestone. In the flatwoods portion of the county lying east of Santa Fé. Hague, Gainesville and Lochloosa the Ocala is at a greater lepth and the surface formations: are the sands and clays of the Altm Bluff and some thin limestone belonging to the Glendon formation. This latter is well exposed near the town of Hawthorne where in years past it was quarried for building purposes. Here it is soft and porous, but in many places limestones of this formation are silicified and form thin beds of cherty boulders or. as in some of the old phosphate workings, a phosphatic conglomerate. This limestone is relatively thin in this region and rests upon the pure soft Ocala limestone, which, over that part of the county lying to the west of Gainesville, outcrops at the surface or lies just beneath a thin mantle of sand. Payne's Prairie, near Gainesville, and the whole Alachua sinkhole region are due to the underground solution of the Ocala limestone: in only a few of the larger sinks is any rock visible however, on account of the thick sand covering which has masked the steep sides of the depressions. This same Ocala limestone is exposed to a depth of 2.5 to 40 feet in the phosphate mines in western Alachua County, at High Springs in the north, and all through the comtry between IVilcox and Newberry. Several pits have been operated at different points in the county to mine the limestone itself: with one exception, the Arredondo Lime Company, which manufactures quicklime. the product is used as road material.

Pit of the (ummer Lumber Company $1 / 4$ miles southeast of Xasbcry-In this pit 20 feet of creany yellow soft Ocala limestone is exposed under a cover of $i$ to 8 feet of yellow clayey sand, and is quarried to water level. On the whole the limestone is very soft, crumbling in the hand, but scattered irregularly throughout the pit are harder masses of grayish limestone. Nany vertical solution channels and potholes give the quarry face an impure look and cause the operators considerable trouble to quarry around. Following are four analyses by the Testing Division of the State Roal Department:

Analyses of Limestone from pit of Cummer Lumber Company.

$\left.\begin{array}{l}\text { Calcium carbonate }\left(\mathrm{CaCO}_{33}\right) \ldots \ldots \\ \text { Magnesium carbonate }\left(\mathrm{MgCO}_{3}\right) \ldots \ldots\end{array}\right\}$

Iron, Alumina and Oxides.............

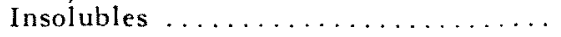

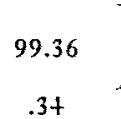

.16

\subsection{0}

.61
$+.80 \quad .58$

$.80 \quad .25$

97.90

.06
.+6
1.24 
Pit of Gaineszille Lime Rock Company, six miles southruest of Gainesville-The Ocala limestone is quarried here for road-building purposes. The limestone is worked to a maximum depth of twenty-one feet after stripping a thin (1-2 $1 / 2$ feet) covering of red-brown clayey loam. The rock is very soft, pure and homogeneous; clay pockets extending down to the bottom of the pit are quite numerous and have rendered the limestone about them quite impure and dirty; some flint or chert is also found close to these pockets.

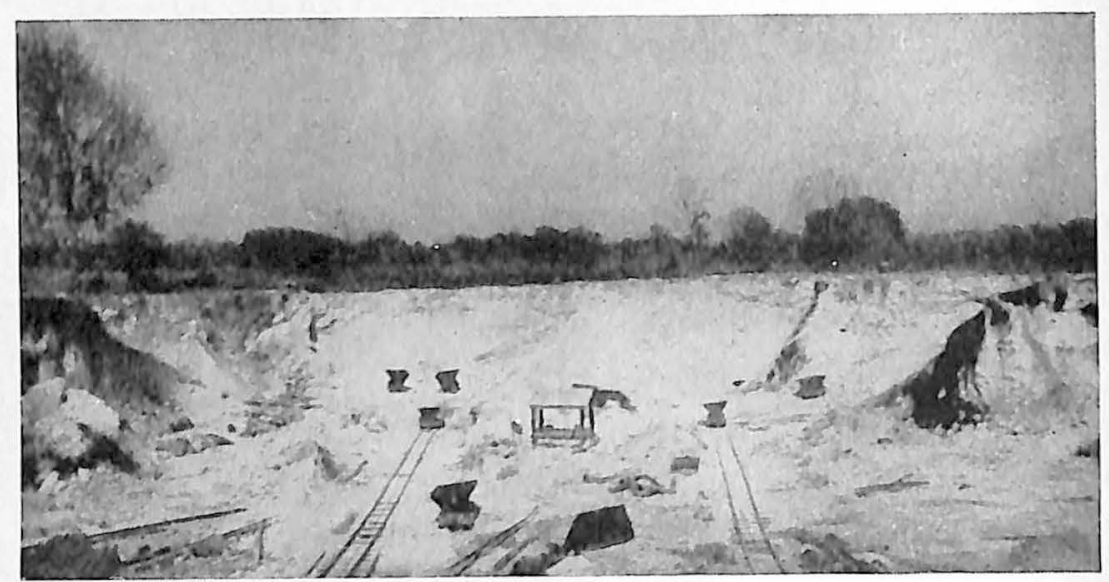

Fig. 27.-Ocala limestone in pit of Gainesville Lime Rock Company, Arredondo.

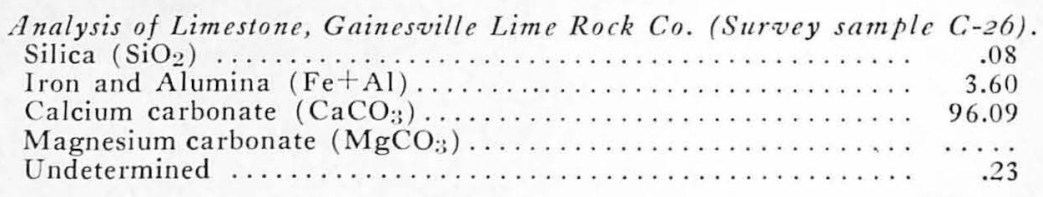

Total ................................. $\overline{100.00}$

Pit of Arredondo Lime Company, 5T/2 miles southwest of Gainesville-The Ocala limestone is worked at this locality for the manufacturing of quicklime. The pit exposes ten feet of limestone under one to one and one-half feet of dark gray sand. Clay pockets are very abundant and greatly hinder the working of the deposit. The limestone is very soft and pure, but easily crumbles to an almost powdery form ; few or no hard lenses of rock are present, and though the soft phase is very desirable chemically, it clogs in the kiln, is harder to handle and does not burn as well as more compact or semicrystalline rock. 


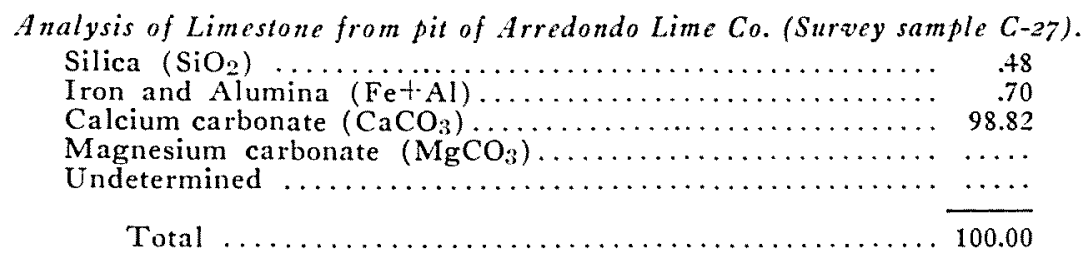

The pits described above are typical of this county, the limestone is very uniform, occurs under a thin cover and is easily accessible for development. Other places in the county where the rock has been quarried, usually for local road building purposes, are Wilcox, Fanning Springs and Archer.

\section{BAKER COUNTY}

Baker County lies in the northeast part of the State. The surface is moderately rolling except in the northern portion which is covered by the southern extension, from Georgia, of the Okefinokee swamp. The surface formations are all unfossiliferous red and yellow sands and sandy clays of undeterminate age, which are referred to the Alum Bluff group of lower Miocene time. No lime deposits are known to exist near the surface; the Ocala limestone is probably present but at a depth which is unknown, as no deep wells have been recorded.

\section{BAY COUNTY}

Bay County is on the Gulf coast in West Florida. In the higher inland portion to the north the Choctawhatchee marl is found along the streams that have cut down through the sands and sandy clays of Pliocene and Pleistocene age, but this formation dips seaward and at Panama City lies about 50 feet beneath the surface.

Property of Bryan Scott on Econfina Creck, three miles southrost of Betts-Econfina creek, flowing through a wooded country of high sandy ridges, has cut down and exposed here about 15 feet of the Choctawhatchee marl. The location of the deposit makes it fairly accessible to development, for although under a heavy sand cover, the stream has cut down a broad $\mathrm{V}$-shaped ravine, exposing the marl near the bottom where it could be worked in the bank.

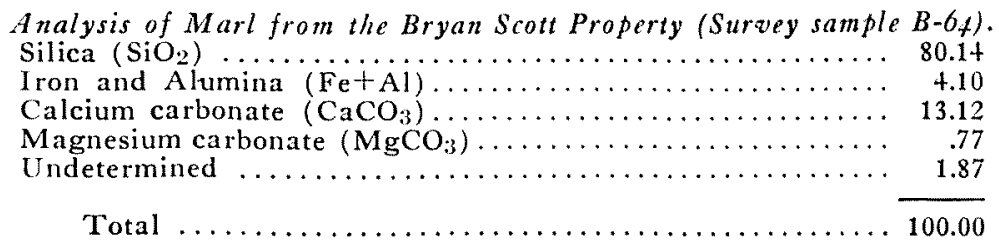


The chief use of this marl would be as a soil corrective. though the lime content is rather low; phosphate is often present but always in small (1\% or less) quantities. Few large shells are present, the shell material is in small fragmentary form widely scattered in a dull olive green matrix, chiefly made up of sand.

On E,confina creek, about a mile north of this location but on the same property, is about 30 feet of light, tawny-colored clayey sand that may be part of the Alum Bluff phosphatic marl. This deposit lies on a steeply sloping hillside and was at one time worked as a fertilizer.

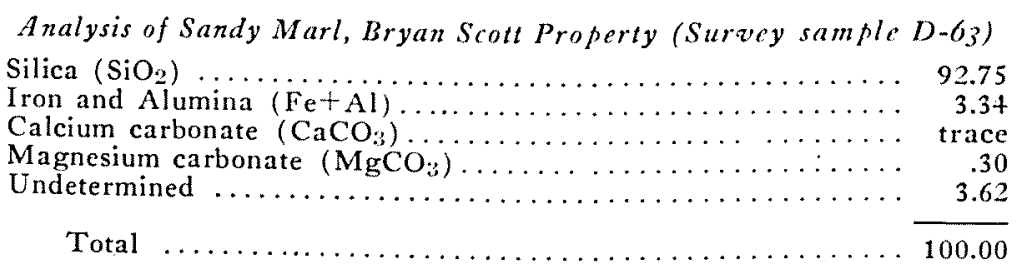

The high "undetermined" probably indicates a low phosphate content.

\section{BRADFORD COUNTYY}

Bradford County is located in the northeastern part of the peninsula. It is mostly flatwoods entirely covered by unconsoliclated sands and sandy clays of undetermined age. In the hammock belt in the extreme western part, the Ocala limestone may be found near the surface, but this formation dips away from the higher area in the center of the peninsula and passes under the rest of the county at a considerable depth.

\section{BREVARD COUN'TY}

Brevard County is located on the Atlantic Coast about half-way down the peninsula. It is a county of very low relief and is covered by sands, shell marls and coquina beds of Pleistocene age. The shell marls are found widely distributed all through the mainland and on Merritt's Island, while the coquina is practically confined to a narrow strip along the mainland facing the Indian River and the sonth end of Merritt's Island. The marls have not been generally utilized except on Merritt"s Island where a marl bed has been dredged to a clepth of three to five feet and used in the construction of roads; the material there is an intimate mixture of white sand and shells, often consolidated to such a hardness that it will ring under a blow of the hammer. When laid out 
on the road and rolled, it quickly cements, forming a hard surface. Material from Indian shell mounds is also used in road construction in many places.

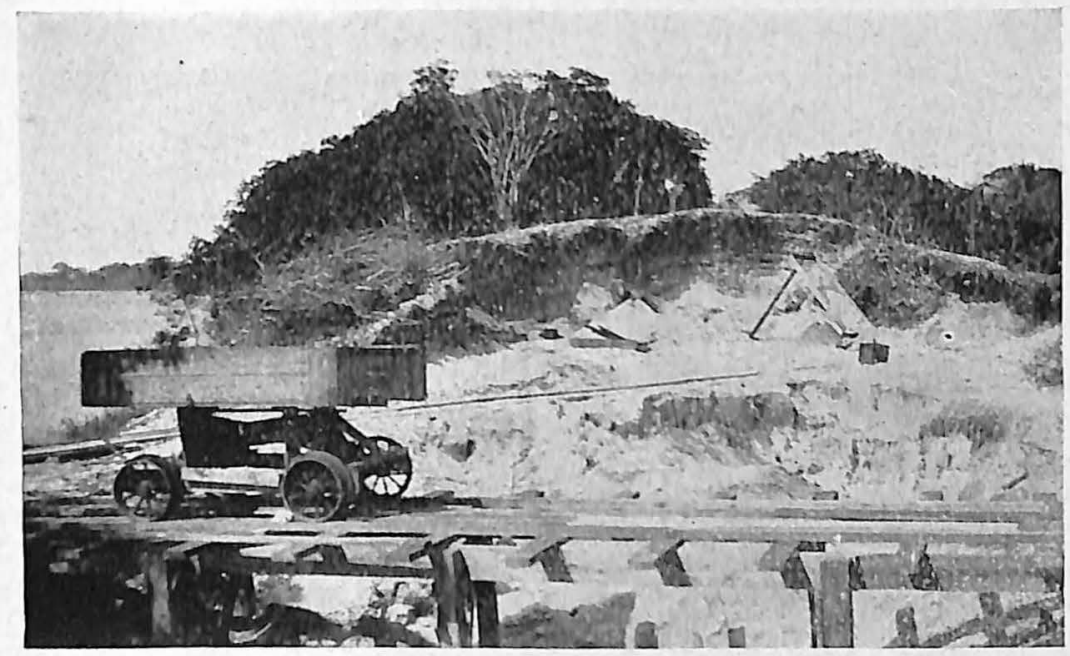

Fig. 28.-Shell mound on Indian River opposite Melbourne.

Coquina has been worked at several localities in the county, principally at Indian River City and three miles north of Ean Gallie. Ledges of coquina can be seen outcropping along the main highway in the vicinity of Rockledge. In the abandoned pits one mile south of Indian River City eight to fourteen feet of coquina is present under a two-foot cover of dune sand. The uppermost two to four feet of the rock has been consolidated to form hard ledges, but the material lying below this is entirely unconsolidated clean shells and shell fragments. The hard ledges make excellent building or facing stone and are sometimes crusherl and used as a base in road construction. The unconsolidated clean shell matter is ideal for manufacturing artificial coquina blocks or to take the place of gravel in concrete aggregates; some of this loose coquina has been used locally as a top or "facing" for roads made of pure soft limestone.

Pit of Carl H. Fay, three miles north of Eau Gallie-The coquina quarried on this property has a thickness of from five to seven feet; it outcrops at the surface or is covered with only a very thin loam and sand 
mantle. It is made up of consolidated shells and shell fragments with a small quantity of intermingled sand; in most of the material the shells are much broken up, giving the rock a quite smooth face, but in irregular layers in different parts of the pit the shells are almost whole or in large

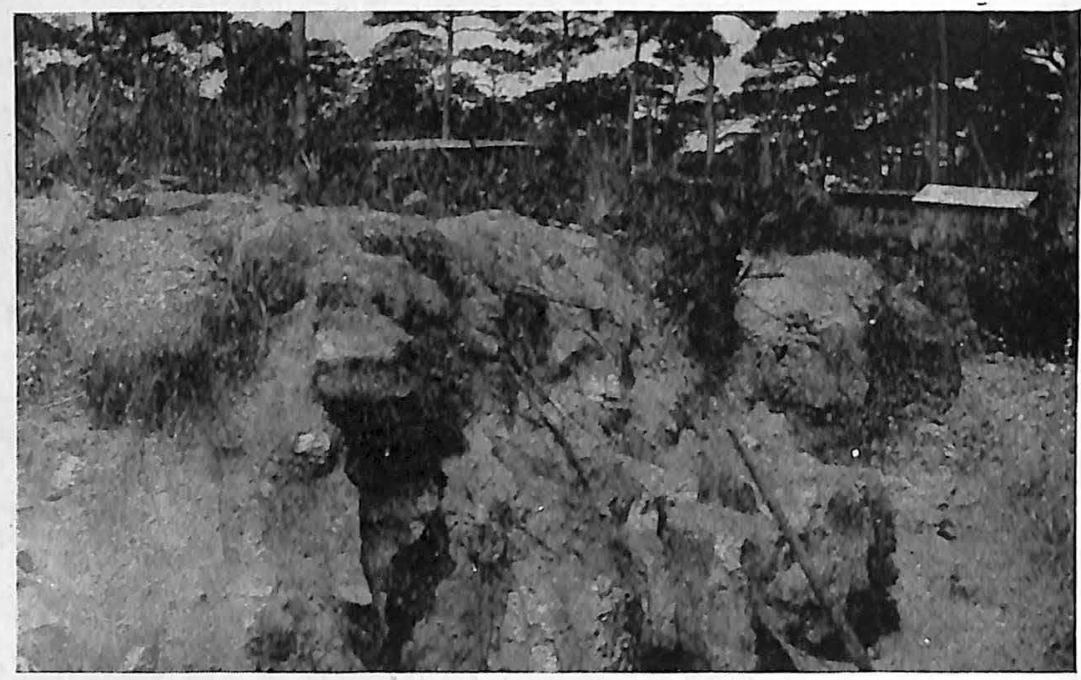

Fig. 29.-Coquina in Carl Fay pit, near Eau Gallie.

fragments, resulting in a rock of coarser texture. Some of the rock quarried here is used for facing houses or in chimney building, but the larger portion is crushed and used as a base for asphalt roads. The streets of Melbourne, Melbourne Beach, Cocoa, Cocoa Beach and many other nearby thoroughfares are constructed of this material with excellent results.

Analysis of Coquina from Pit of Carl Fay (Survey sample C-113).

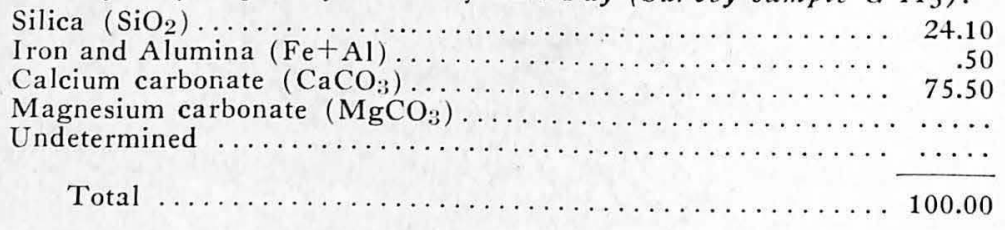

Analyses of this hard building coquina will vary in silica and lime content and even in the same pit no two may be the same. The general limits are $\mathrm{CaCO}_{3} 65$ to 93 per cent; $\mathrm{SiO}_{2} \%$ to 35 per cent. 


\section{BROW ARD COUNTY}

Broward County is situated on the Atlantic coast, well down the peninsula, miclway between Palm Beach and Miami. The beds exposed at the surface are somewhat varied in character, sands, marls, and limestones, but all are of Pleistocene age. By far the greater part of the county lies within the Everglades and the formations are masked by muck and heary regetation. but drainage canals cutting through the central and western portions of the comty have been of great value in securing gcologic data on this otherwise unknown territory. As far a can be told from sections thus exposed, the western part of the county is underlain by thin shell marls and impure limestones of Pleistocene age, probably resting on the Calousahatchee marl, although this latter formation has not been encountered on the southeast side of Lake Okeechobee. About twenty miles back from the coast an oolitic limestone much like the typical Miami oolite is encountered. This limestone covers a strip about ten miles wide in an east-west direction, but its north and south limits are as yet undetermined. About six miles west of Fort Lauclerdale the typical Miami oolite is found, this formation extending northward from here into Palm lieach County, but thins out and becomes quite sandy. In the vicinity of Hallandale and Dania it is found in workable deposits, but no pits have as yet been opened here, owing. no cloubt, to the quarries at Ojus just across the county line, which have been operated for the last twenty years and supplied all the rock needed.

\section{CALHOUN COENTY}

Calhoun County is located on the Gulf Coast of West Florida immediately west of the Apalachicola river. In the northern end of the county the Choctawhatchee and Chipola marls of Miocene age are found exposed along the Chipola river and its tributaries, and in all probability the Chattahoochee and Glendon formations are also present in small areas there. No outcrops of limestone are seen, but the gentle depressions around Altha and in that vicinity are indicative of the solution of limestone lying at no great clepth. The area underlain by these four formations, constituting only about one-fifth of the total county, is quite hilly and rolling. but these beds dipping seaward soon pass beneath the surface and the greater portion of the county. lying to the south, is of low relief, and underlain by sands and sandy clays of Pliocene and Pleistocene age. 
Marl bank of W. H. Baxley at Darling's Slide, Chipola RizerLnder a cover of 33 feet of sand and sandy clays, :31 feet of the Choctawhatchee marl is present in a vertical face at this locality. The lower 21 feet of the formation consists of a greenish-gray sand matrix with great numbers of small bivalve shells scattered throughout, the upper ten feet is a lighter steel-gray unfossiliferous clay. The marl is dug out of the bank and hoisted on steeply inclined rails to the plant at the top where it is dried and ground to a powdery fineness. It is used as a soil corrective.

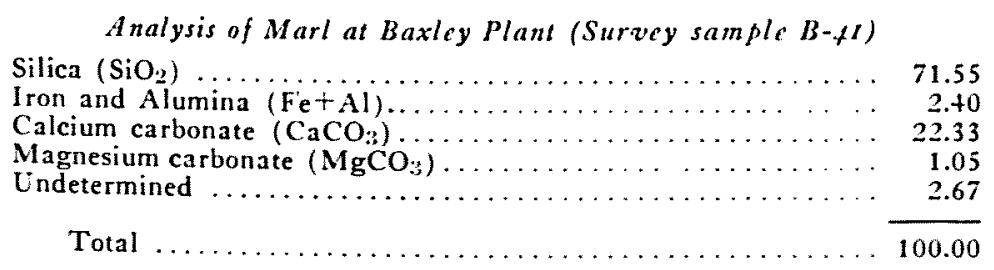

The high "undetermined" in the analysis suggests the presence of phosphates and other plant foods. An analysis of a sample of the finished product gives the following result for these foocls :

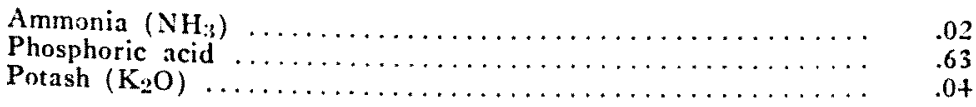

Ten-Mile Creck, four miles north of Clarksille-The Chipola marl outcrops in the broal creek bottom under a cover of about twelve feet of yellow sandy clay. Because of the high water at time of writer's visit no complete section could be seen, but the marl exposed to water level had a thickness of three to five feet. It consists of a gray-blue sandy matrix with many soft or "rotten" shells.

Analysis of Marl on Ten-Mile Creek (Survey sample B-77).

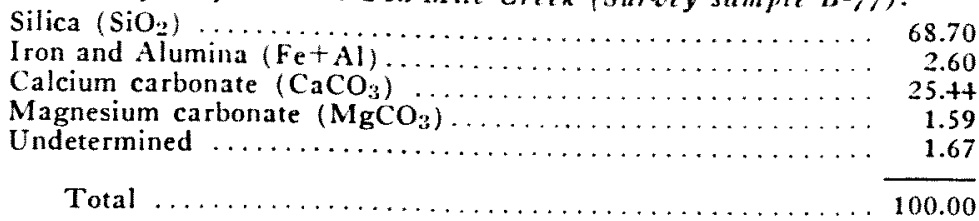

The chief use of this marl would be as a soil corrective. 
Section,

$$
\text { Four-Mile Creck, Bluff Half Mile Wrest of Bridge. }
$$

(t) Sandy loam in steeply sloping bluff, approximately 50 feet

(3) gray micaceous clay.................... 4 feet

(2) gray blue marl to cover............... s feet

(1) under cover to water.................. 5 feet 8 inches

The marl seen at this location is the typical very fossiliferous greenish-gray Choctawhatchee. The lower wo feet of number 2 of the above section is composed of almost pure shells closely packed; above this the marl grows progressively less shelly and grades into the micaceous clay. which probably has a greater thickness but is masked by the sand cover.

\begin{tabular}{|c|c|}
\hline Analysis of Marl on Four-Mile Creek (Survey sampl & \\
\hline Silica $\left(\mathrm{SiO}_{2}\right) \ldots$ & 77.80 \\
\hline Iron and Alumina $(\mathrm{Fe}+\mathrm{A})$ & 3.10 \\
\hline Calcium carbonate $\left(\mathrm{CaCO}_{3}\right)$ & 17.60 \\
\hline Magnesium carbonate $\left(\mathrm{MgCO}_{3}\right)$.. & .60 \\
\hline determined & .90 \\
\hline
\end{tabular}

If only the more shelly part of the marl were worked the lime content would be considerably increased. The plant-food value of the marl here is probably low, the lime content gives its chief value as a soil corrective.

\section{CHARTOTTE COLNTI}

Charlotte County lies on the Gulf coast in South Florida. It is a very flat-lying area and rock outcrops are few; in the western part along the l'eace River the Caloosahatchee marl is well exposed, and it probably unclerlies the whole county. Thin shell marls of Pleistocene age overlie this throughout much of the county. These marls, though usually unconsolidated, are often found cemented together in large bouklers and are broken up for use as road material. This hardened marl has been so used in constructing the main road from Sarasota to Punta Gorda ; about four miles west of Murdock the following sample was taken from a depth of three to five feet.

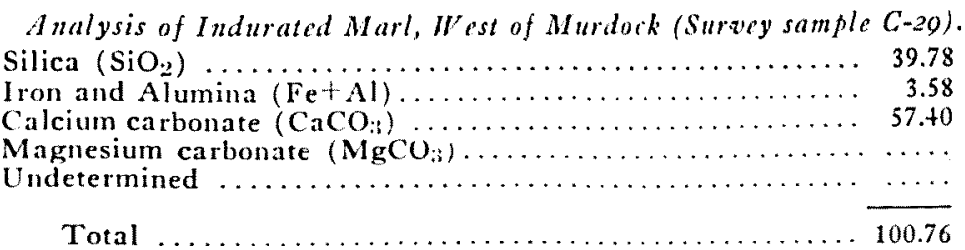

'This material is almost flint-like in hardness, and in analysis is an impure limestone; it should make good road material, though it may 
be hard to crush and roll. Where the marl is unconsolidated it may not run so high in lime, but will be easier worked and will serve quite well for highway purposes.

\section{CITRUS COUNTY}

Citrus County lies on the Gulf coast in the northern part of the peninsula. It is underlain chiefly by the Ocala limestone of Eocene age and variable thicknesses of Pleistocene sand; in the extreme southern part of the county the Tampa limestone is found. Over a large part of the county the limestone outcrops at the surface or uncler a thin ( 2 to 3 feet) cover of sand, though in many localities this sand mantle thickens up considerably. Hard rock phosphate which is deposited in the Ocala limestone was formerly mined at many places throughout the central and eastern parts of the county and numerous exposures of the Ocala formation are to be seen in these workings. Many lime pits have been opened in different parts of the county to supply the stone for local highway construction and have been abandoned after the work was completed. The four pits described below operate steadily the year round and ship their product into nearby counties.

Pit of the Crystal River Rock Co., five miles southeast of Crystal River-The limestone in the quarry belongs to the Ocala formation, but it is much harder than usual (per cent of wear, 8.6; French coefficient,

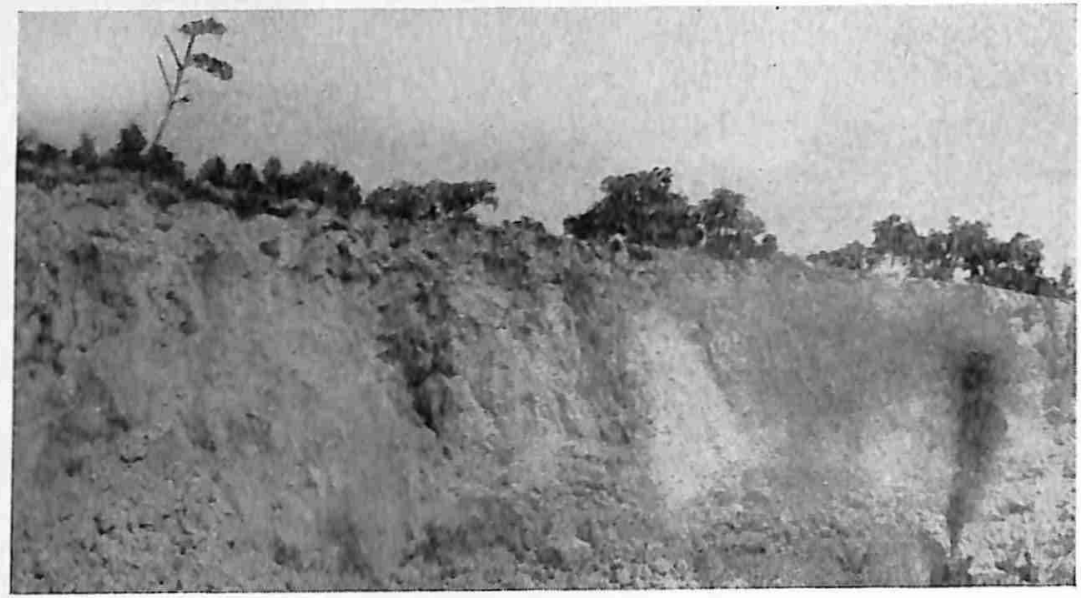

Fig. 30.-Ocala limestone in Crystal River Rock Co. pit near Crystal River. 
4.65), and possesses a semicrystalline character differing markedly from the typical soft, almost chalk-like nature of this limestone. This hardening seems to be the work of downward percolating waters which have penetrated the limestone by way of narrow solution channels or crevices, lining them with crystals of calcite and aragonite. The quarry now has a vertical face about 115 feet high, the greatest exposed thickness attained by this formation in Florida; the cover is very thin, one to three feet, and immediately below this lies six to ten feet of porous chalky limestone which passes into the harder material. The deposit is not uniformly composed of semicrystalline rock, for occasionally there occur, especially toward the bottom of the pit, masses of the soft unaltered typical Ocala limestone. This soft material is used as a road material, but by far the greater production of the pit is sold as railroad ballast and concrete rock. The limestone of this quarry is noteworthy both for its hardness and its exceptional purity.

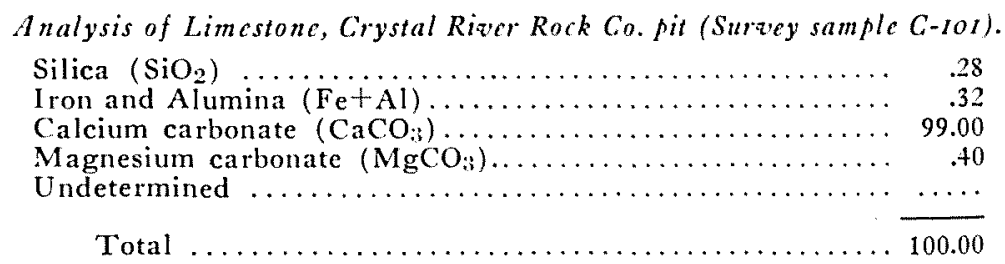

'The following are the extremes and average of five analyses by the Testing Division of the State Road Department:

$\begin{array}{lccc} & \text { High } & \text { Low } & \text { Average } \\ \text { Silica }\left(\mathrm{SiO}_{2}\right) \ldots \ldots \ldots \ldots \ldots \ldots & 2.96 & .54 & 1.30 \\ \text { Iron and } \mathrm{Alumina}(\mathrm{Fe}+\mathrm{Al}) \ldots & .92 & .24 & \text { only three analyses } \\ \text { Calcium carbonate }(\mathrm{CaCO}) \ldots & 98.95 & 96.05 & 98.19 \\ \text { Magnesium carbonate }\left(\mathrm{MgCO}_{3}\right) & .80 & .45 & .55\end{array}$

Pit of Conncll \& Schults, one mile south of Pincola (Hooper Sid$i n g$ ) - This pit exposes 35 feet of the typically soft pure Ocala. Although soft as a rule there are harder masses scattered irregularly through the deposit. These are not at all semicrystalline, merely locally consolidated limestone. No flint or chert is present and only a few pot-holes or pockets carry clay; on the whole the pit is exceptionally free from impurities. 'The entire output from this pit goes into highway construction. 
Analysis of Limestone at Connell \& Schultz pit, one mile south of Pincola (Survey sample $C$-102).

Silica $\left(\mathrm{SiO}_{2}\right) \ldots \ldots \ldots \ldots \ldots \ldots \ldots \ldots \ldots \ldots \ldots \ldots \ldots \ldots \ldots \ldots \ldots \ldots \ldots \ldots \ldots \ldots \ldots \ldots . .18$

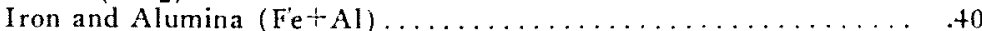

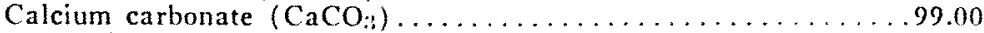

Magnesium carbonate $\left(\mathrm{MgCO}_{3}\right) \ldots \ldots \ldots \ldots \ldots \ldots \ldots \ldots \ldots .40$

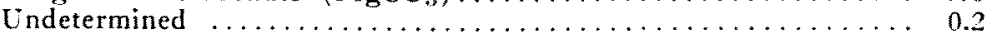

Total

100.00

Following are the results of four analyses by the Testing Division of the State Road Department from this pit:

$\begin{array}{lrcc} & \text { High } & \text { Low } & \text { Average } \\ \text { Silica }\left(\mathrm{SiO}_{2}\right) \ldots \ldots \ldots \ldots \ldots \ldots & 2.66 & .84 & 2.08 \\ \text { Magnesium carbonate }\left(\mathrm{MgCO}_{3}\right) & .70 & .30 & .58 \\ \text { Calcium carbonate }\left(\mathrm{CaCO} \mathrm{CO}_{3}\right) \ldots . & 98.90 & 96.60 & 97.40\end{array}$

In the vicinity of Pineola are two other pits being worked for road material; both are in the soft Ocala limestone and are quartied to a depth of about 20 to 25 feet.

Number One pit of Connell \& Schulte, trio milcs north of PincolaResults of ten analyses by the Testing Division of the State Road Department :

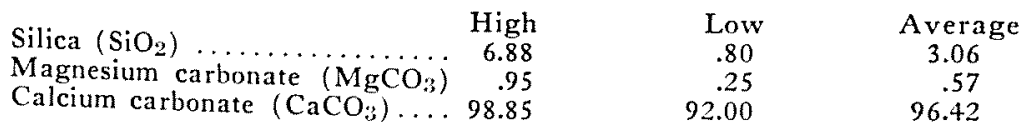

This pit has many clay pockets that hincler operations and lower the usual high lime value. It has recently been abandoned.

Analysis of Limestone, Pineola Quary (C. W. Hunter), Pincola.

Silica $\left(\mathrm{SiO}_{2}\right)$ (Survey sample $D-23$ ).

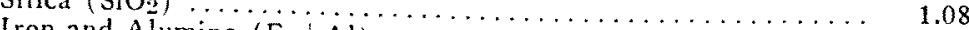

Calcium camina $(\mathrm{Fe}+\mathrm{Al}) \ldots \ldots \ldots \ldots \ldots \ldots \ldots \ldots \ldots \ldots \ldots, 1.20$

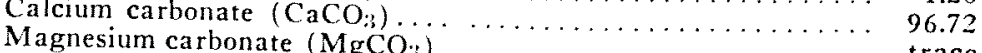

Undest

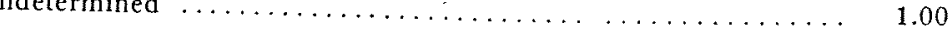

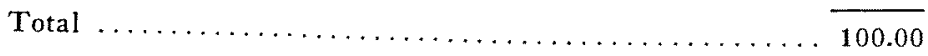

Results of six analyses by the Testing Division of the State Road Department:

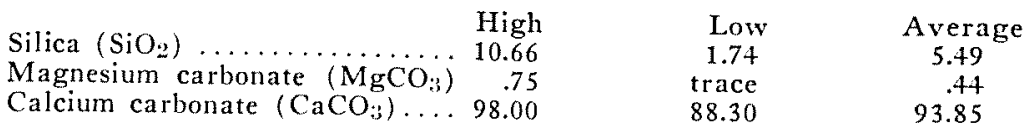


The Crystal River Rock Company is operating a large pit one mile north of Istachatta. 'The rock here is the usual soft Ocala just as described in the other pits in that section, quite pure and compact, but here stained with many clay pockets.

One mile west of the main Brooksville-Inverness highway on the road to Hebron Church, a small pit in a gentle depression shows eight to nine fect of the Tampa limestone with little or no overburden, though a heavy sand mantle covers the limestone elsewhere in the vicinity. The rock is hard, dense, even-grained and almost crystalline. It occurs in a fairly compact mass, but is irregularly fractured and weathers into easily crumbled material with a yellow-green color and characteristic conchoidal fracture. In the bank the rock looks irregular and lense-like. but upon close examination the material is seen to be practically all hard but occurs in irregular masses.

The following is an analysis of this limestone (Survey sample C-15\%):

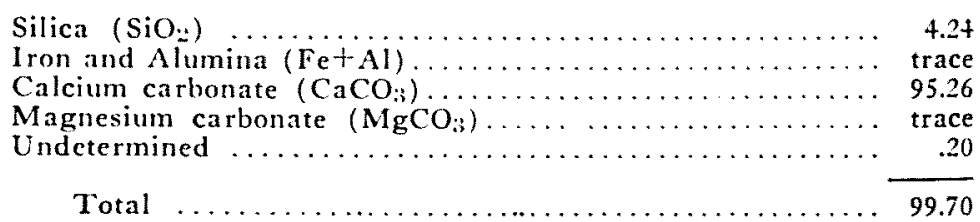

From the number of exposures seen distributed widely over all parts of the county it is clear that good soft limestone can be found at practically any place desired except in some of the higher ridges where the sand mantle is too thick to make a quarring venture profitable. Clay pockets are quite common in the southeastern portion of the county and should be guarded against by careful prospecting. Good deposits of hard limestonc occur in the extreme south-central part of the county.

\section{CLAY COUNTY}

Clay County lies in the northeastern part of the peninsula just west of the St. Johns river. Phosphatic marls of the Alum Bluff group (Miocene) are found in some of the creek bottoms and along Black creek near Midclleburg thin marly limestone of Miocene age is seen. This rock is usually quite soft and porous, seldom over six feet thick, not 
uniformly continuous and limited in areal extent. Most of the surface of the county is covered by sands and sandy clays of doubtful age.

\section{COLLIER COUNTY}

Collier County is on the Gulf coast in southern Florida. The surface formations are all of Pleistocene age and include sands, shell marls and thin impure limestones. The marls are often consolidated to form a brittle impure limestone, and are worked in many localities to shallow depths from one to three feet to provide road material. No analyses of these marls and limestones were made, since they consist almost entirely of $\mathrm{CaCO}_{3}$ and $\mathrm{SiO}_{2}$ which will vary in quantity widely from place to place. The lithology changes with equal rapidity also, though the loose to slightly consolidated marl is more widespread than any other formation.

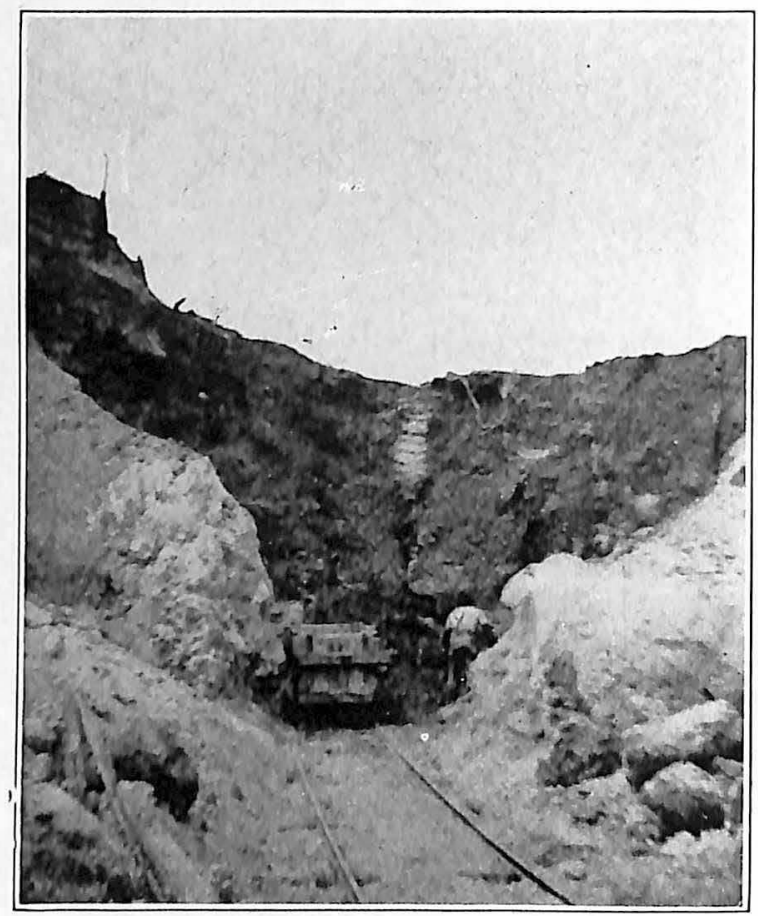

30a.-Ocala limestone in hard rock phosphate pit, Ft. White. 


\section{COLUMBIA COUNTY}

Along the Santa Fé river, in the old phosphate mines in the vicinity of Fort White, and elsewhere in southern Columbia county the Ocala limestone is found at the surface. Lying as residual boulders in the Ocala or as a thin bed are remnants of the Glendon limestone; northward toward Lake City the red and yellow sands and sandy clays of the Alum Bluff overlie the limestones which here probably dip gently toward the north and east, away from the structurally high area around Live Oak. Just above White Springs on the Suwannee river in Hamilton County are some marls that have been classified as Alum Bluff; the limestone from which the spring itself flows is the Glendon, which underlies this section at no great depth judging from the frequent chains of sink holes bordering the river.

\section{DADE COUNTY}

Dade County is on the Atlantic coast, occupying the southeastern tip of the mainland. The western part of the county lies within the Everglades, and consequently is very imperfectly known; in all probability shell marls and thin limestones underlie the muck of this area. A strip eighteen to thirty-five miles wide extending along the coast is underlain by the Miami oolite, which can be seen outcropping all through this region. In the northern part of the county this formation is quite

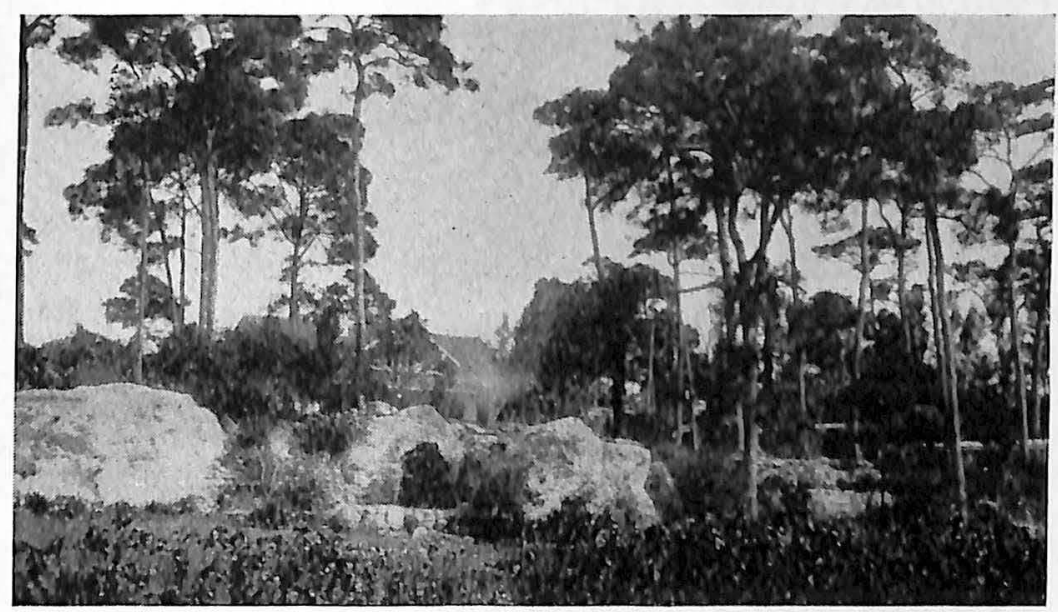

Fig. 31.-Exposure of Miami oolite at Silver Bluff, near Miami. 
sandy, but toward the south becomes more pure. It is used extensively as road material, building stone, and in concrete mixtures.

Pit of Maule Ojus Rock Company, Ojus-This pit, covering about 400 acres, lies near the ocean and is connected with it by a canal; the rock is dredged from a depth of twenty-two feet, only about three feet of rock showing above water level. The rock is broken up in situ by dynamite and dredged up in comparatively small lumps. The limestone is the Miami oolite, containing much free sand, but has undergone replacement in the presence of water so that the resultant is a hard, jagged, semicrystalline limestone, very irregular in structure and breaking with rough edges. A good deal of sand has been incorporated into the limestone.

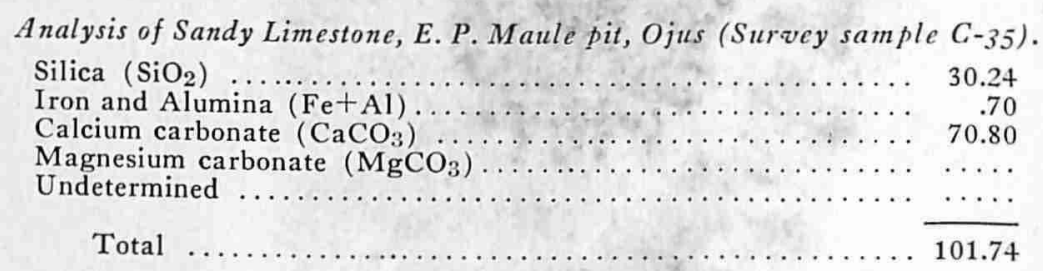

Result of 18 samples by the Testing Division of the State Road Department:

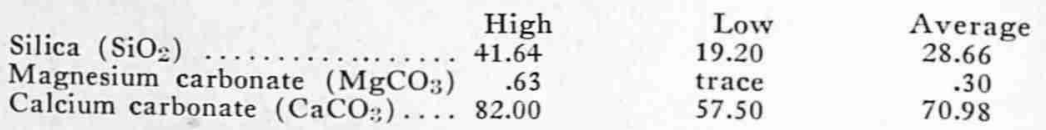

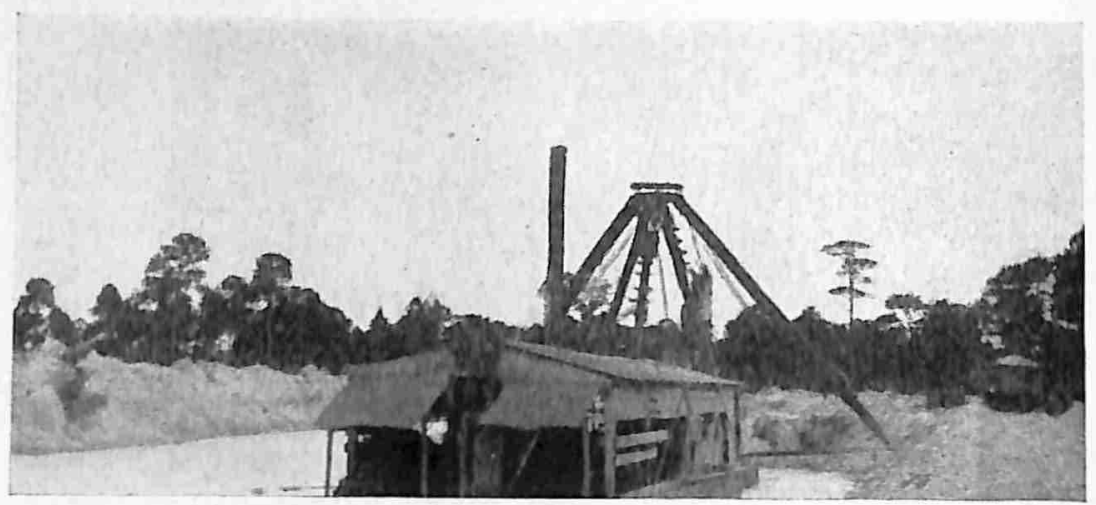

Fig. 32.-Rear view of dredge in Ojus Rock Company pit, Ojus. 
Pit of Ojus Rock Company, Ojus-The Miami oolite in this pit is worked to a depth of 29 feet. Two to five feet of white sharp sand covers the rock, and in solution holes extends down into it for several feet. In the "north end of the pit eight to ten feet of limestone is dug above water level by steam shovels; in the southwest end the land lies lower and the rock is quarried below water level by means of a floating dredge. The limestone is oolitic in the main, and soft, but has undergone replacement so that much of it has become semicrystalline about shell masses and has lost a good deal of its oolitic appearance. The hardness is not in masses or of irregular occurrence, but the whole body of the limestone runs hard and soft throughout. The structure seems to be a jagged, vesicular mass of hard replaced material with the voids and pits filled with softer material. A large amount of sand has been bound up in the rock during this replacement process.

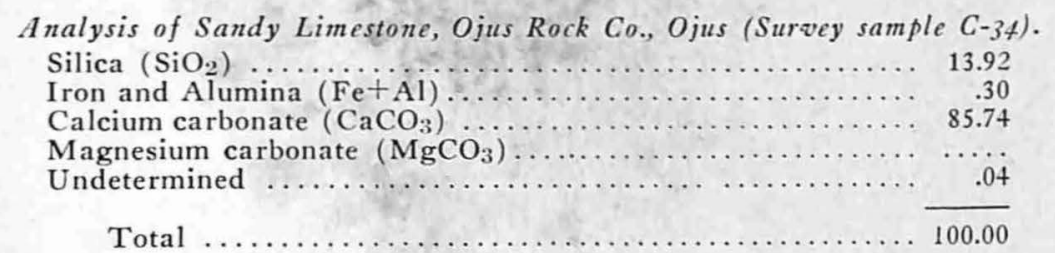

Result of 12 analyses by the Testing Division of the State Road Department :

\begin{tabular}{|c|c|c|c|}
\hline & High & Low & Average \\
\hline Sili & & & 38.08 \\
\hline$(\mathrm{CaCO}$ & 72.40 & 46.00 & 61.82 \\
\hline esium carbonate $\left(\mathrm{MgCO}_{3}\right)$ & .40 & .10 & .24 \\
\hline
\end{tabular}

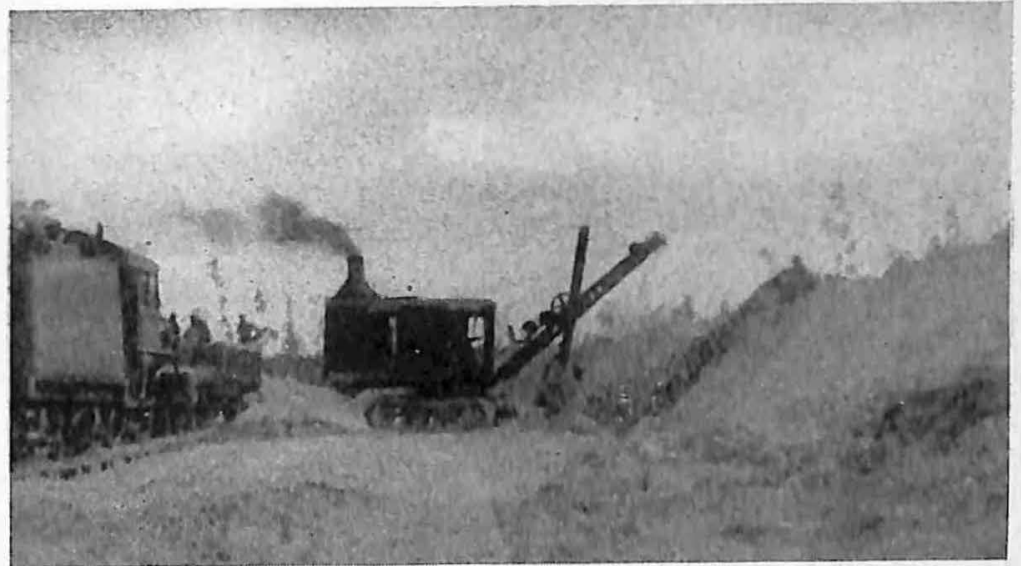

Fig. 33.-Miami oolite in pit of Ojus Rock Company, Naranja, 
Pit of the Ojus Rock Company, Naranja-Ten to twelve feet of the Miami oolite is worked in this pit for use as road material. There is no overburclen, since all through this section of commtry sonthwest of Coconut Grove the limestone outcrops at the surface with an indurated uneven surface. The rock is very pure. soft and homogeneous, but a few small shallow "pot-holes" carrying red sandy loam are present. No flint or concretions or semicrystalline limestone is encountered.

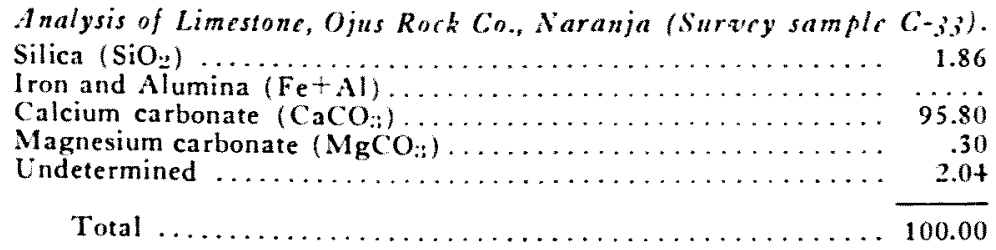

Result of five analyses by the Testing Division of the State Road Department :

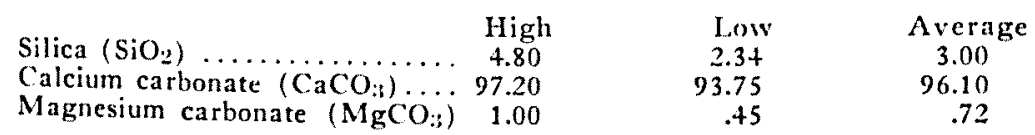

In the vicinity of Miami and sonthward many pits have been opened to supply, locally, road material and building stone. The above pit is typical of this area. in which limestone outcrops almost everywhere. at the surface, and is soft, pure and homogeneous.

\section{1): soto CoU Nat"}

De Soto Comty, lying in the wcstern part of southern Florida. is underlain principally by the Caloosahatchce marl of Pliocene age. Outcrops of this formation are scarce in this flat-lying region and are masked by a thick mantle of l'leistocene sand. Some thin Pleistocene marls are scattered irregularly over the county, especially in the western part. These marls are little developed though are quite useful as road material.

DIXIL COUNTY

Dixie County is on the Gulf coast immediately west of the Suwannee river, mostly in the Gulf Hammock region. The soft Ocala limestone outcrops at the surface or under a thin sand cover over this whole region. In the north a few residual boulders or remnants of the Glendon are occasionally found. No quarries operate regularly in this county, but at many places the Ocala limestune has been quarried to supply road 
material locally: There are several pits of shallow ( 1 to 5 feet) depth in the area between Cross City and Oldtown, and a pit one-half mile east of the Taylor County line on the Perry-Cross City road was worked to a depth of nine feet to supply rock for this main highway. Following are two analyses from this place by the Testing Division of the State Road Department :

Silica and insolubles $\left(\mathrm{SiO}_{2}\right) \ldots \ldots \ldots \ldots \ldots \ldots, .67$

Calcium carbonate $\left(\mathrm{CaCO}_{3}\right) \ldots \ldots \ldots \ldots \ldots \ldots . .67 .96$

Magnesium carbonate $\left(\mathrm{MgCO}_{3}\right) \ldots \ldots \ldots \ldots \ldots, 1.80$

1.32

97.72

1.16

\section{Devir. covers}

Duval County is situated on the Atlantic const in the northeastern part of the State. Plcistocene sands cover the northern and western parts of the county: the area around Jacksonville and the southwestern portion of the cominty are underlain by Miocene sediments, mostly sands and clays, though some thin marly limestone is present. This limestone is not well exposed nor continuous. but is encountered at no great depth in all wells drilled in the territory mentioned. It is of practically no commercial value.

\section{FSCAMBIA COUNT}

Escambia is the westermmost connty of Florida. The only formations exposed are sands and clays of Pliocene and Pleistocene age. No lime deposits are known to occur near the surface within the county borders.

\section{FLAGLER COUNTY}

Flagler County lies on the Atlantic coast in northeastern Florida. The eastem section is underlain by thin Pleistocene shell marls and, nearer the coast. copuina. In the southwestern corner of the comty these Pleistocene sands and marls rest in all probability on the Nashua marl, though no exposures of this formation were seen in that area. The coquina is the only lime material that has been developed commercially.

County road pit $21 / 4$ miles north of Flasler Beach on the Old Dirie Highray-Fifteen to eighteen feet of coquina is exposel here under $11 / 2$ feet of red sandy clay. The top ten to twelve feet is in leiges of hard. compact, pure shell masses; below this there is two to four feet of clean unconsoliclated shell that stands in a vertical face. 'This unconsoliclated shell gracles down into about three feet of similar material that has dark earthy matter intermixed. Both the compact and unconsoli- 


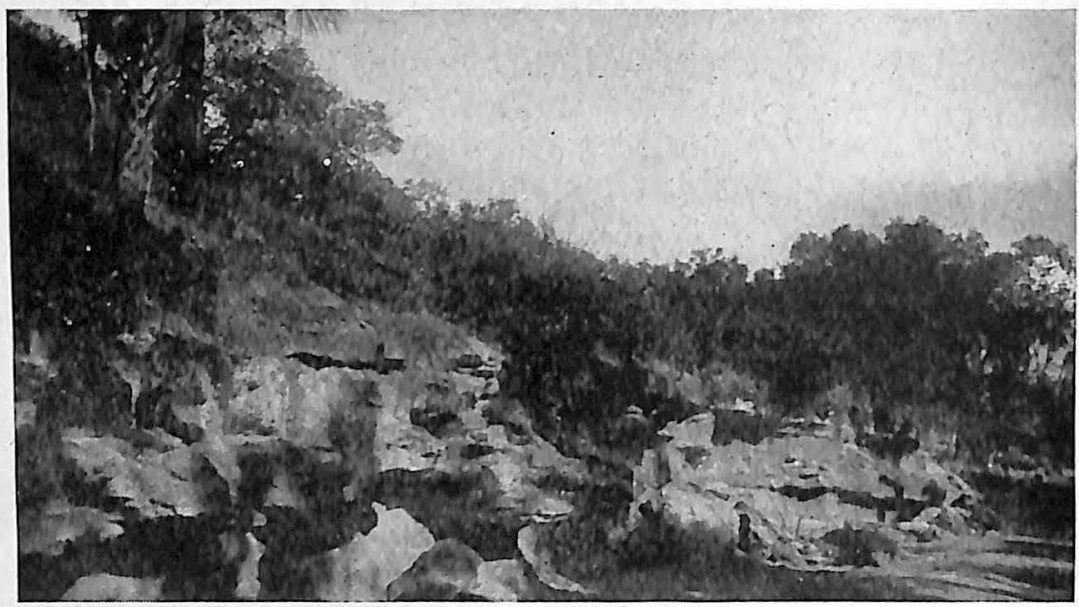

Fig. 34.-Coquina in county pit near Flagler Beach.

dated coquina are used solely in road construction, though the harder material would make excellent building stone as well. Just across the road is another shallower pit in much the same material, but at a depth of seven to eight feet an exceptionally hard, well-cemented coquina was struck that was too difficult to work and the pit was abandoned. Chemically this material will vary between $10 \%$ to $25 \% \mathrm{SiO}_{2}$ and $75 \%$ to $90 \% \mathrm{CaCO}_{3}$. Iron and alumina seldom amount to more than $1 \%$.

\section{FRANKLIN COUNTY}

Franklin County lies on the Gulf coast, mostly in micldle Florida, ketween the Ocklocknee and Apalachicola rivers. In the eastern part of the county impure limestone and the Choctawhatchee marl of Miocene age lie very near the surface, while along New river in the vicinity of Knox Still Landing some marl of Pliocene or Miocene age is found. Exposures are rare in this low flat-lying region, however, and a thick mantle of Pleistocene sand covers practically the whole county.

\section{GADSDEN COUNTY}

Gadsden County occupies the angle formed by the Apalachicola river and the Georgia State line. In the extreme northwestern section the Chattahoochee limestone outcrops over a limited area; in the northeast portion a limestone of doubtful age (Glendon) is found along and 
near the Ocklocknee river. The high central part of the county (300 feet in altitude) is underlain by sands and clays of the Alum Bluff group (Miocene) and in the south the Choctawhatchee marl comes to the surface in a few scattered outcrops. Of these formations only the Chattahoochee limestone has been quarried and that only on a very small scale. At the old Chattahoochee Landing along the main highway there is a bluff in which is exposed sixty-five feet of the Chattahoochee limestone (see page 84). Following are two analyses from this location. The first is from the upper forty-five feet of the formation which appears purer and slightly harder. The second analysis is from the lower twenty feet which seems softer and less pure, but chemically there is little difference.

Analysis of Upper Part of Chattahoochee (Survey sample B-37).

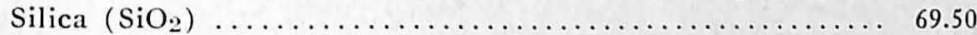

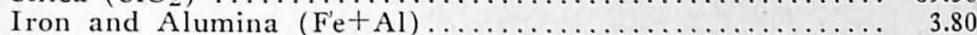

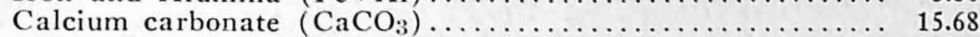

Magnesium carbonate $\left(\mathrm{MgCO}_{3}\right) \ldots \ldots \ldots \ldots \ldots \ldots \ldots \ldots \ldots \ldots \ldots \ldots$

Undetermined $\ldots \ldots \ldots \ldots \ldots \ldots \ldots \ldots \ldots \ldots \ldots \ldots \ldots \ldots \ldots \ldots \ldots \ldots \ldots \ldots \ldots, \quad 02$

Total ........................ $\overline{100.00}$

Analysis of Loquer Chattahoochee (Survey sample B-36).

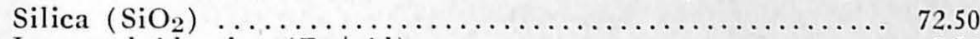

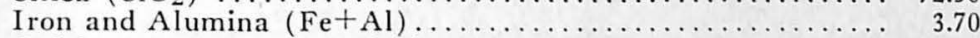

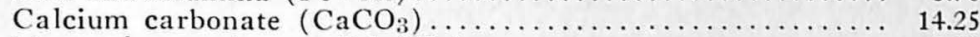

Magnesium carbonate $\left(\mathrm{MgCO}_{3}\right) \ldots \ldots \ldots \ldots \ldots \ldots \ldots \ldots \ldots, \quad 9.08$

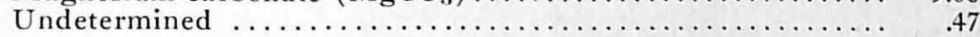

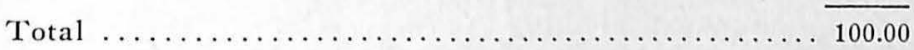

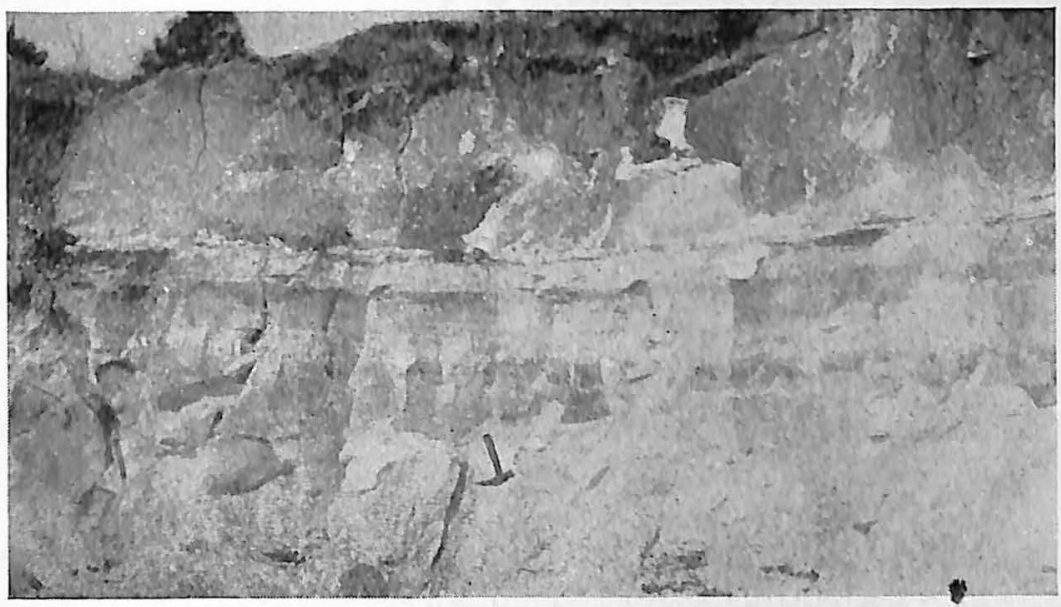

Fig. 35.-Chattahoochee limestone, exposed in pit one-half mile east of Insane Asylum, Chattahoochee. 
The two foregoing analyses at the Landing were from rock that has undergone a certain degree of weathering and in all probability the carbonates have been partially leached out. Other analyses of rock of this formation that has been exposed to weathering agencies for long periods show that the combined carbonates may not be above $2 \%$ to $4 \%$ while the silica will be around $95 \%$.

One-half mile east of the Insane Asylum, on the Quincy road, a small working has recently been opened to supply material for a small local dam embankment; this is a fresh unweathered face and the analysis of the sample from this place is probably most representative of the formation.

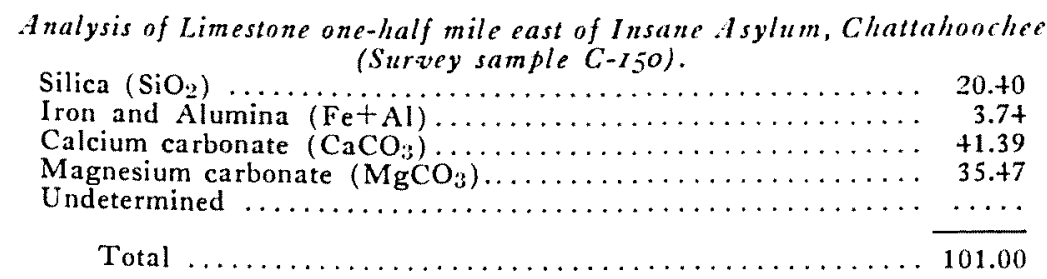

In 1898 near the town of River Junction a plant was opened to quarry the Chattahoochee limestone for use as a natural hydraulic cement ; in that one year $\%, 000$ barrels were produced,* but it was liscovered that the formation varied too widely in chemical composition and the venture was abandoned.

Along the Ocklocknee river, in the vicinity of Pronto Springs, four miles east of Concord, there are many sink-holes that expose limestone of probably Glendon age. One sink in particular about one hundred yards northeast of the spring shows, under 34 feet of sand and sandy clay, 18 feet of a light cream-gray impure limestone with much rellow clay staining matter. Normally it is very soft except where exposed to rumning water in stream channels, etc. Here the rock has been altered to a smooth flinty material.

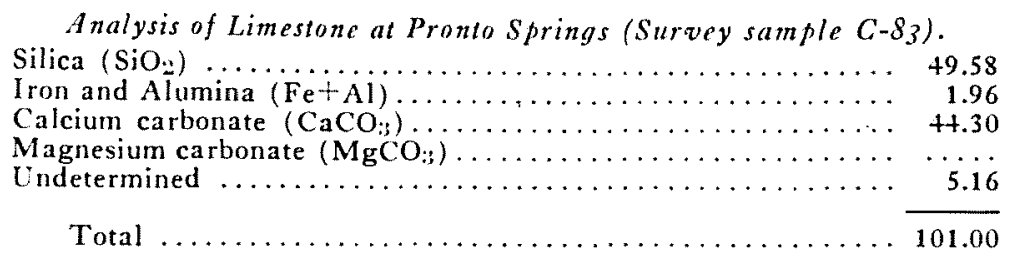

*20th Ann. Rept. U. S. Geol. Survey, pt. 6 (Cont.), p. 5+7, 1899. 
Even the soft material from which the sample was taken has been much weathered and for this reason the silica content is high and the lime low. The high undetermined possibly indicates a phosphatic content.

The cover is too thick over most of this region to make quarrying profitable, and even should a piece of property be found where the limestone is near the surface, it would be wise to take a number of samples in order to determine the chemical composition more accurately than can be done from sampling weathered surface outcrops.

\section{GLADES COUN'Y}

Glades County, bordering the western side of Lake Okeechobee, is very flat and has few exposures of geologic value. The whole county is underlain by the Caloosahatchee marl with a thin covering of sand and different Pleistocene shell marls. In the southern part of the county along the Caloosahatchee river and in the area bordering the lake these more recent shell marls are six to eight feet thick and have been used to a consiclerable extent locally as road material. These are made up of large masses of shells with about $40 \%$ to $60 \%$ of light yellow sand. The whole is loose and marls here are seldom consolidated. In the northern and westem parts of the connty the Caloosahatchee marl is probably the surface bed, but no development has as yet been made of it.

\section{HAMILTON COUNTY}

Hamilton County lies in middle Florida, the Georgia State line forming its northern boundary. The western border is marked by the Withlacoochee river and the southern and eastern by the winding Suwannee. The whole county is covered by reddish-yellow sands and sandy clays of Alum Bluff ( Miocene) and some light-colored Pleistocene sediments, the latter chiefly along the rivers and in the southwestern part of the county, which is in the hammock belt. The rivers lave cut down through these unconsoliclated beds and their channels now are in the Glendon limestone; many exposures can be seen, particularly on the Suwannee, on which rock is exposed almost continuously from Ellaville to White Springs. At Suwannee Springs hard semicrystalline limestone of Glendon age attains, under seventeen feet of sand cover, a thickness of 16 feet and $t$ inches with the base passing beneath the water. The upper five feet is weathered into hard and soft masses, but the lower 11 feet and 4 inches is the typical hard, light-gray semicrystalline phase. In 
the extreme northeastern portion limestone is present, but under a fairly thick mantle; close to the Withlacoochee river many sink-holes can be seen, but the rock is usually masked by the overlying soil and debris. On the river at Bellville, 6 feet and 3 inches of this hard, light-gray Glendon limestone outcrops with the base passing below water level. The cover here is of light yellow-gray sand 18 feet thick. The following analysis is from this location:

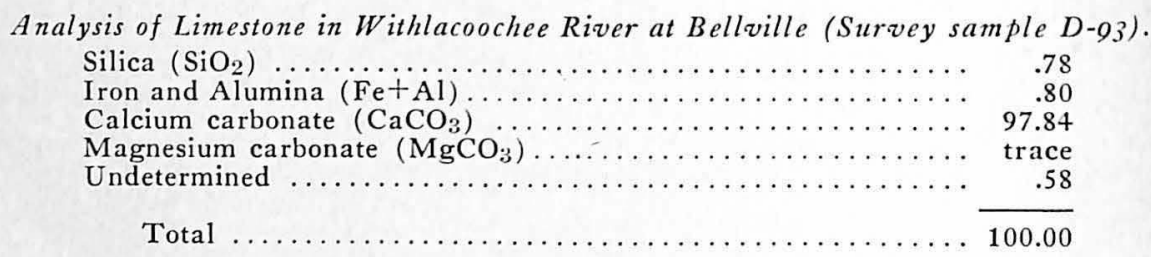

In the north-central part of the county, along the Alapaha river, conditions are much the same as just described; between the Withlacoochee and the Alapaha the country is higher and the limestone lies at a greater depth, near the river, however, the country has been eroded and the bed of the stream itself flows in a rock channel; small sink-holes are developed all through the country bordering the river. One mile east of Jennings on the Alapaha river, just above the old cemetery, 10 feet and 4 inches of the Glendon shows above the water level under 12 feet 6 inches of sand. This rock has been much weathered, and is made up of hard, small, rounded knobs, smooth and white; back of this

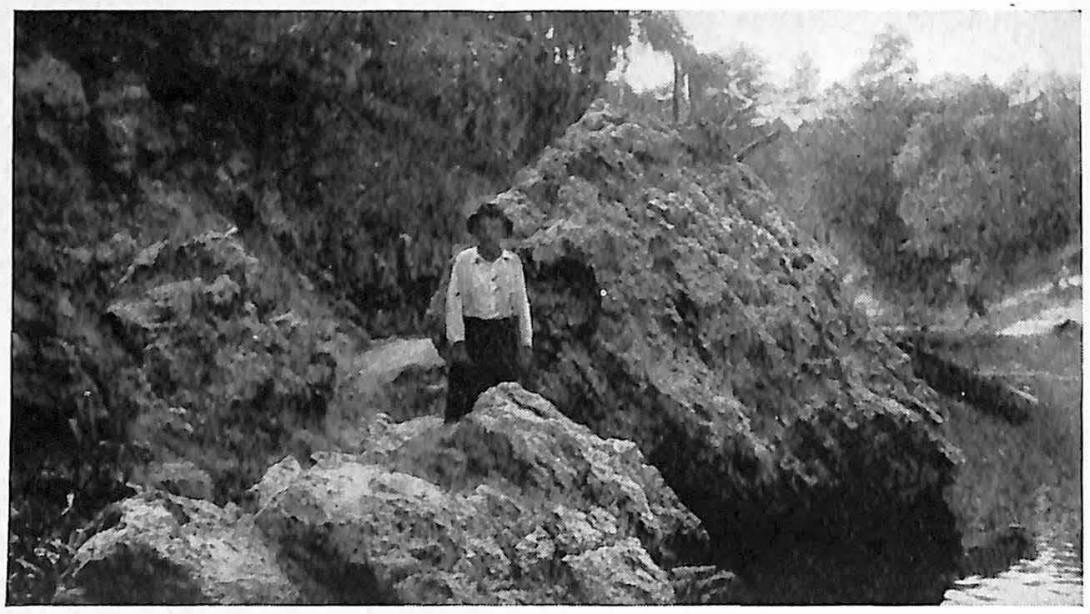

Fig. 36.-Weathered Glendon limestone along the Alapaha river, near Jennings. 
rough-pitted face the rock is very hard, but has a slightly impure grayyellow color. An analysis of the limestone from this location is given below.

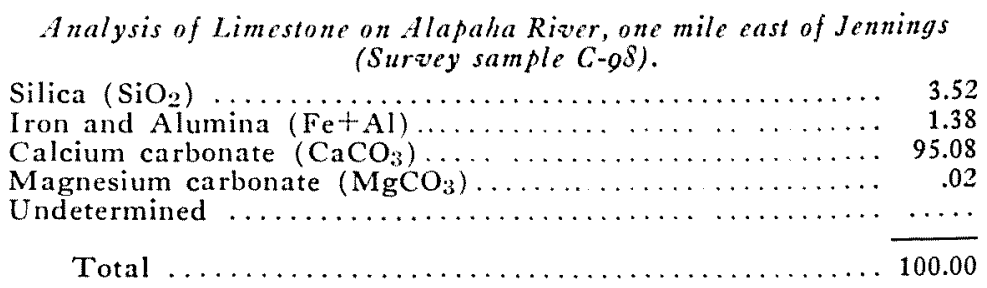

The Glendon limestone underlying this county seems of good grade, high in calcium carbonate and low in impurities; the weathered faces are of course indurated and semicrystalline, and it is highly probable that in this area the formation will also have these characteristics even under cover. Over most of the county the cover is too thick to warrant opening a pit, but near the river and in the southwestern portion or hammock belt the rock should lie near enough the surface in places to make such a venture possible.

\section{HARDEE COUNTY}

Hardee County is mostly flatwoods underlain by the phosphatebearing Bone Valley formation (Pliocene) and the Alum Bluff sand and sandy clays. Some marl of the Caloosahatchee may occur along the south borders of the county, but is very limited in areal extent.

\section{HENDRY COUNTY}

Hendry County lies in South Florida just southwest of Lake Okeechobee. The surface is flat and the formations are all sands and marls of Pleistocene age, except in the northwest portion along the Caloosahatchee river where the marl of that name outcrops. In the vicinity of LaBelle and Fort Thompson, marls and thin limestones of Pleistocene age, several feet in thickness, overlie the Caloosaliatchee and are userl locally in highway construction; in the interior of this flat-lying county thick sands mask any possible outcrops.

\section{HERNANDO COUNTY}

Hernanclo County lies on the Gulf coast in west-central Florida; physiographically it is marked by the high hammocks in the middle portion, passing into lime-sinks and flatwoods to the east and north. 
Almost the entire county is underlain by the Tampa limestone which is often masked by a considerable thickness of yellow-brown sands and sandy clays; along the extreme eastern boundary of the county the Ocala limestone is found at the surface.

The two centers of limestone industry are the Brooksville area, producing hard rock, and the Istachatta area, producing soft rock.

Plant of Florida Rock Products Company, threc-fourths mile southiiest of Brookszille-This is without a doubt the most completely equipped hard limestone plant in the State and is the only producer of washed hard rock graded to meet every need of the contractor. The limestone, which is worked to a depth of thirty-five feet under one to three foot cover of dark sandy loam, belongs to the 'Tampa formation. It occurs in hard light-gray to white boulders or fractured masses cemented together with soft clayey limestone which looks somewhat like fuller's earth; there are very few clay pockets and no flint in the deposit, but tiny cracks carry impurities all through the main body of the rock and are quite numerous. Because of the soft material and impuritie: the quarry-run rock is submitted to a very thorough washing process that is constantly in operation from the time the material enters the preliminary crushers, on through the log washers and thence to the final crushers and graders that sort the rock into storage bins. The plant has a capacity of about five hundred tons daily, the rock sizes ranging from the $21 / 2$-inch railroad ballast to the $1 / 8$-inch and smaller screenings.

Silica $\left(\mathrm{SiO}_{2}\right) \quad \ldots \ldots \ldots \ldots \ldots \ldots \ldots .6 .54$

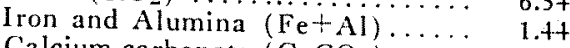

Calcium carbonate $\left(\mathrm{CaCO}_{3}\right) \ldots \ldots .96 .91 .09$

Magnesium carbonate $\left(\mathrm{MgCO}_{3}\right) \ldots$ trace

Undetermined

Total $\overline{100.00}$

French Coefficient Test; Testing Division of State Road Dept.

Per cent of wear......... 6.3

French coefficient .......... 6.3

This rock is used in many ways-as a concrete aggregate, railroad ballast, highway construction and mixed with asphalt in road surfacing. Abandoned pit of the Brooksville Quarries, fice miles southiest of Brooksille-This pit was formerly worked for concrete rock and railroad ballast. The limestone, belonging to the Tampa formation, is hard semicrystalline, light brown to cream in the fresh face but bleaching out to a cream-white. Throughout the deposit irregular layers or boulders of harder, darker colored rock frequently occur; many clay-filled solu- 


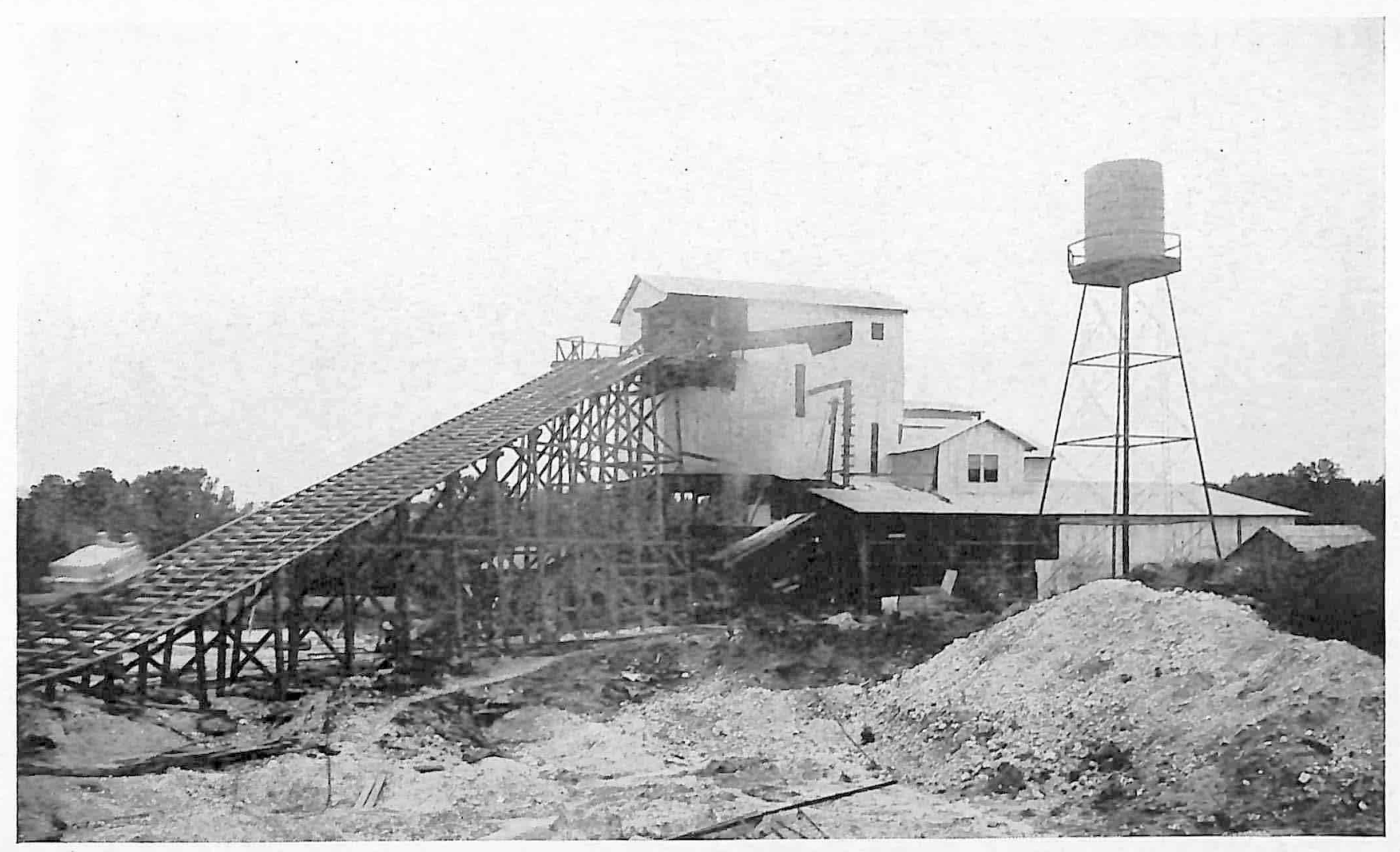

Fig. 37.-Plant of the Florida Rock Products Company, Brooksville. 
tion holes are present and a large number of irregular cracks or fissures that carry red-brown clayey sand all through the limestone. Although the main bulk of the rock is hard, there is much soft limestone present surrounding these hard masses. The exposed face shows twenty-nine feet of limestone under two to three feet of gray-white sand.

\begin{tabular}{|c|c|c|}
\hline Silica $\left(\mathrm{SiO}_{2}\right)$ & 5.64 & \\
\hline $\begin{array}{l}\text { Iron and Alumina }(\mathrm{Fe}+\mathrm{Al}) \ldots \ldots \\
\text { Calcium carbonate }(\mathrm{CaCO} .\end{array}$ & 1.44 & French Coefficient Test; Testing Divi \\
\hline Magnesium carbonate $\left(\mathrm{MgCO}_{3}\right) \ldots$ & $\begin{array}{l}91.00 \\
\text { trace }\end{array}$ & artment. \\
\hline Undetermined & 1.28 & Per cent of wear. \\
\hline Tota & 00,00 & \\
\hline
\end{tabular}

Hernando County pit, five miles southeast of Brooksillle, on the Dade City Road-This pit is operated to supply road material locally. About fifteen feet of soft clayey-appearing limestone with many hard nodules is exposed, overlain by one or two feet of sand and loam. The material is cream to white with some greenish coloring matter; it is very clay-like in appearance, fissile and breaks with a fracture similar to fuller's earth. Hard limestone nodules two to ten inches in diameter are quite common, scattered irregularly throughout the deposit.

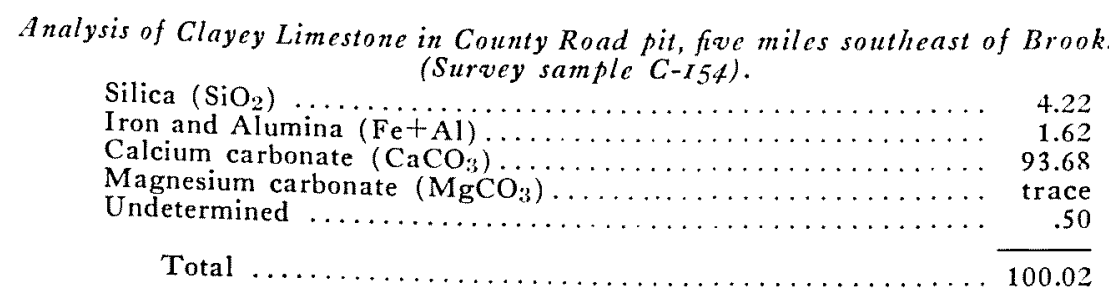

Property of C. and J. Camp, five miles northcast of Brooksille-At the time of the writer's visit the plant was in the course of construction and the pit not yet started, but several prospect holes had been dug in the rock to a depth of twenty-five feet to forty feet. The material thus viewed and sampled was quite similar to that in the pit of the Florida Rock Products Company, consisting of irregular masses of hard limestone, cream to light gray in color, at times as solic as flint, other times jagged and full of voids because of casts of fossil shells. In between these hard masses is much soft clayey material resembling fuller's earth. 


\section{Analysis of Limestone from C. and J. Camp Property, five miles northeast of Brooksville (Survey sample $C-155)$.}

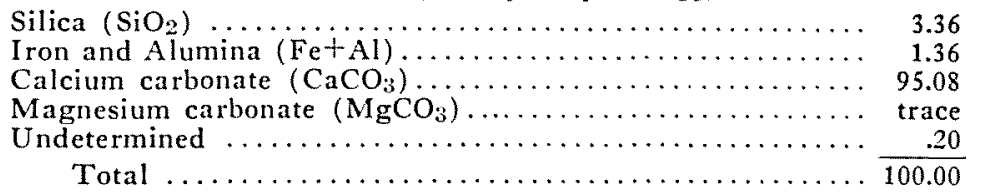

Prospect pit in Annutteliga Hammock, three miles aest of Stafford. A prospect hole sixteen feet deep has been dug here in the Tampa limestone which outerops in this area at the surface or under a very thin sand and loam cover. The rock is light gray to white in color, much softer and more uniform than usually seen in the Tampa, though many hard semicrystalline masses do occur and also some irregular lenses of light-brown limestone, dense, fine grained and almost completely crystalline. All the material except the extremely dense brown rock exhibits the characteristic fuller's earth like fracturing and often carries some light colored yellow to green discoloring matter along the fresh broken faces.

Analysis of Limestone in Anntteliga Hammock, three miles west of Stafford (Survey sample $C-16_{f}$ ).

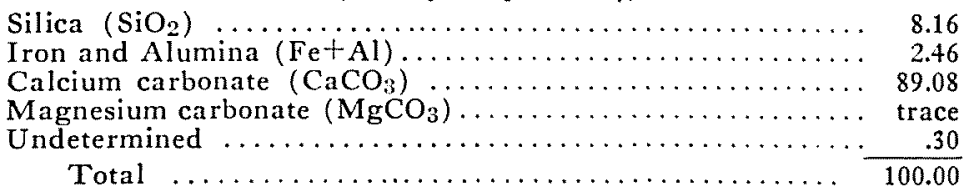

Tournley property, about three miles southwest of Istachatta-The Tampa limestone outcrops here on a small knoll. A prospect hole has been put down which encountered the soft Ocala limestone at a depth of $39 \mathrm{1} / 2$ feet; the rock above this is all Tampa; it does not stand in a smooth face in the hole but runs in hard irregular masses, light cream to white in color, with some clay-like softer material cementing these. The softer material is the irregularly fracturing type of Tampa so often seen. The more compact rock is almost as hard as flint, very even and finegrained and quite uniform in each mass.

Analysis of Limestone from Tournley Property (Survey sample C-160).

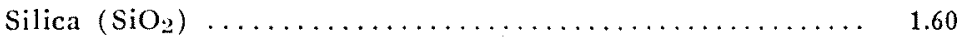

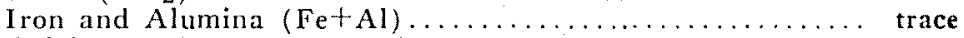

Calcium carbonate $\left(\mathrm{CaCO}_{3}\right) \ldots \ldots \ldots \ldots \ldots \ldots \ldots \ldots \ldots, 98.00$

Magnesium carbonate $\left(\mathrm{MgCO}_{33}\right) \ldots \ldots \ldots \ldots \ldots \ldots \ldots \ldots$ trace

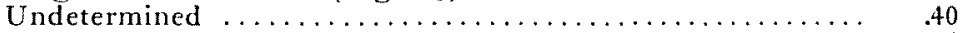

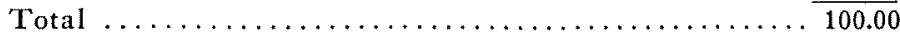


In a narrow strip along the eastern boundary of the county the Ocala limestone lies at the surface or just uncler a thin cover. 'Two miles south of Istachatta the Wm. P. McDonald Construction Company has a pit in this soft pure formation which locally contains a large number of clay-filled pot-holes.

Three miles north of Lacoochee the county is obtaining road material from a shallow pit of Ocala limestone and in this same area there is an abandoned pit of Mickler and McLeod which has until recently been worked for road material.

The extremes and average of twenty-five analyses by the Testing Division of the State Road Department show the uniformity and chemical character of the soff Ocala limestone from this abandoned working:

$\begin{array}{lccc} & \text { High } & \text { Low } & \text { Average } \\ \text { Silica }\left(\mathrm{SiO}_{2}\right) \ldots \ldots \ldots \ldots \ldots & 3.56 & .34 & 1.17 \\ \text { Calcium carbonate }(\mathrm{CaCO} ;) \ldots & 99.50 & 95.25 & 98.16 \\ \text { Magnesium Carbonate }(\mathrm{MgCO}: 3) & 1.10 & .35 & .74\end{array}$

HIGHLANDS COUNTY

The central northern part of Highlands County is in the hilly Lake Region and is underlain by sands and clays considered to belong to the Alum Bluff; in the southern flat part the Caloosahatchee marl is found overlain by variable thicknesses of Pieistocene sand. So far as is known no use has been made of this marl formation in this county.

\section{HILLSBOROUGH COUN'I'Y}

Hillsborough County is on the Gulf coast of southern Florida. The northern and northwestern portions are unclerlain by the Tampa linestone, often masked by variable thicknesses of younger unconsolidated sediments, but exposed in the Hillsborough river at intervals from Crystal Springs near the Pasco County line to Sulphur Springs, a few miles north of 'Tampa. This formation is also exposed near 'Tampa at Ballast Point and Six-Mile creek. Over the eastern part of the connty the sands and sandy clays of the Alum Bluff are present at or near the surface; in the southeastern part these are overlain by the phosphatic Bone Valley formation, while near the coast or Hillsborough Pay, Pleistocene shell marls outcrop at the surface.

Tampa limestone in Sir-Mile Creck, cast of Tampa-The Tampa limestone outcrops in the bed of the stream here and forms solid banks four to six feet high, as well as loose boulders. The material is a fairly hard but not semicrystalline light gray to white limestone carrying an 
abundance of casts and molds of fossils which give it a very irregular fracture. The rock here is normally under a seven to eight and a halffoot cover of shell marl, sand and loam.

Analysis of Limestone in Six-Mile Creek at A. C. L. Bridge (Survey sample C-163).

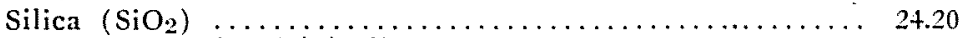

Iron and Alumina $(\mathrm{Fe}+\mathrm{Al}) \ldots \ldots \ldots \ldots \ldots \ldots \ldots \ldots \ldots \ldots, 1.28$

Calcium carbonate $\left(\mathrm{CaCO}_{3}\right) \ldots \ldots \ldots \ldots \ldots \ldots \ldots \ldots \ldots \ldots \ldots \ldots, 74.12$

Magnesium carbonate $\left(\mathrm{MgCO}_{3}\right) \ldots \ldots \ldots \ldots \ldots \ldots \ldots \ldots$ trace

Undetermined $\ldots \ldots \ldots \ldots \ldots \ldots \ldots \ldots \ldots \ldots \ldots \ldots \ldots, \quad .40$

Total $\ldots \ldots \ldots \ldots \ldots \ldots \ldots \ldots \ldots \ldots \ldots \ldots \ldots \ldots \ldots, 100.00$

\section{HOLMES COUNTY}

Holmes County, in West Florida, is almost entirely underlain by the Glendon formation, which in this area is the weathered phase and consists of red to yellow sandy clays with some chert. On the Choctawhatchee river, just below the Alabama State line, expostures of the Ocala limestone can be seen, and farther down the river this rock again comes to the surface but covers in all a small territory. In the southwest coner of the county the Shoal River marl of Miocene age comes to the surface.

\section{JACKSON COUNTY}

Jackson County lies in West Florida, its northern limit the Alabama State line, its eastern, the Chattahoochee and Apalachicola rivers. Four limestone formations outcrop within the borders of the county, placing it among the leading potential producers in the State, as well as the only county in which the Marianna limestone is found. This Marianna limestone outcrops over a small area in the center of the coumty in the region about Cottondale and Marianna, as stated in the description of that formation. North of this the Ocala limestone is the surface formation, while south of it, in the general vicinity of Kynesville, the Glendon outcrops. The limestone of this latter formation is pretty well maskerl by reddish sandy clays. In the extreme eastern part of the county along the Apalachicola river the Chattahoochee limestone covers a small area. The Ocala in the northeastern end of the county is overlain by considerable thicknesses of yellow to buff sands sometimes amounting to fifty feet. At the highway bridge over the Chipola river just east of Marianna, thirteen feet of the Ocala limestone is exposed overlain by thirtythree feet of the Marianna. The upper eight feet of the Ocala here is crean-white and semicrystalline, the lower five feet is soft, porous and quite granular due to the quantity of foraminifera present. The analysis 
given below is of the hardened and weathered phase of the Ocala here exposed:

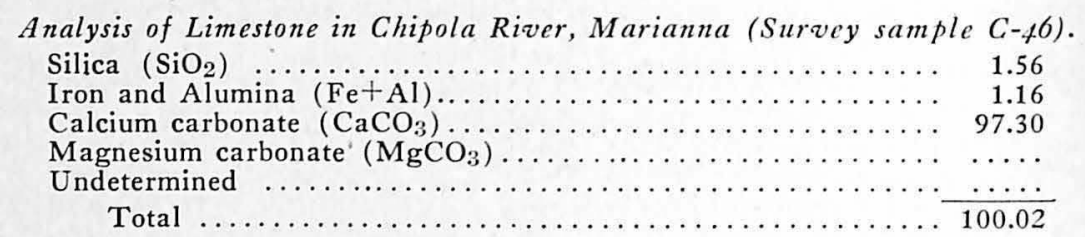

R. D. Daffin Pit, Marianna-In a field adjacent to the locality above mentioned, the Marianna limestone is exposed to a depth of 25 feet, though the present working is limited to the lower 11 feet. The rock here is soft and chalk-like, even-grained and finely compacted; it is sawed out by hand in slabs about five feet by five feet by eight inches $\left(5^{\prime} \times 5^{\prime} \times 8^{\prime \prime}\right)$ and then resawed into the building block or "chimney rock" size, sixteen inches by seven inches by eight inches $\left(16^{\prime \prime} \times{ }^{\prime \prime} \times 8^{\prime \prime}\right)$. When first dug out the stone is very soft and light cream in color, but upon exposure to the air will turn slightly harder and bleach out chalk-white.

Analysis of Limestone in Daffin pit (Survey sample C-47).
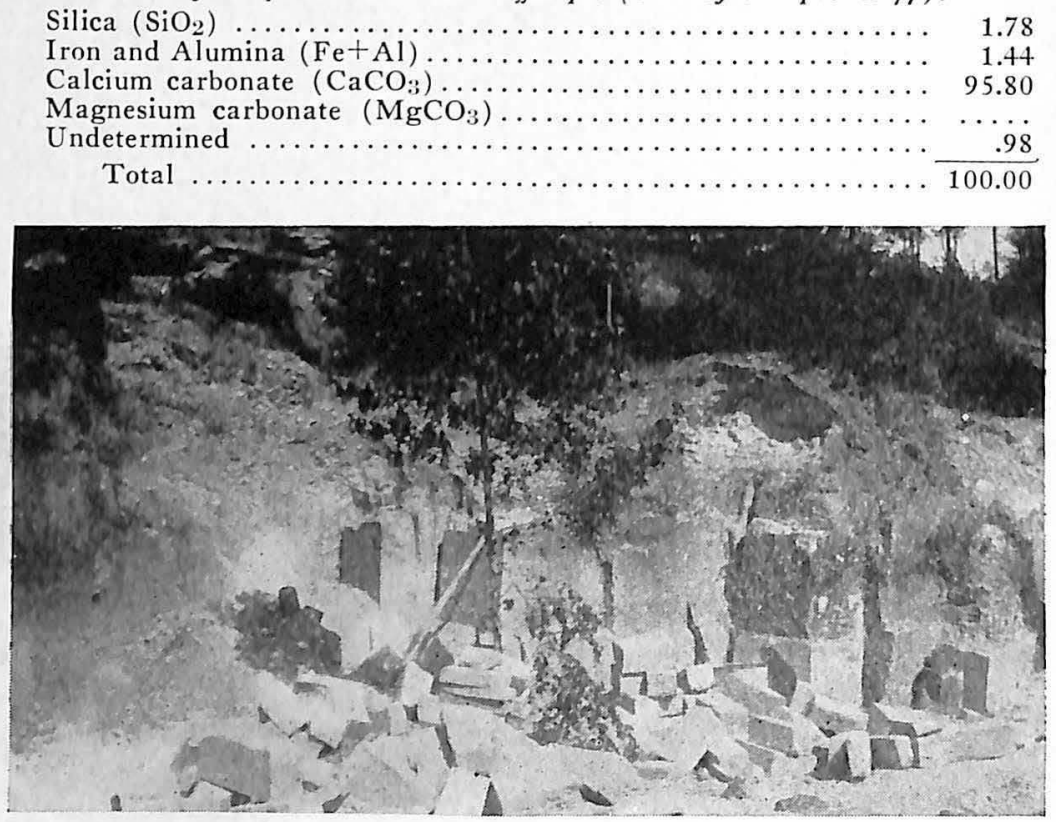

Fig. 38.-Cutting building blocks from Marianna limestone in pit of R. D. Daffin, Marianna. 
In the vicinity of Marianna the limestone which takes its name from the town has been worked in many small pits to stupply local building needs; this production is very sporadic, as the occasion arises the farmer opens up a pit and cuts out a sufficient number of blocks for his needs, so that there are numerous shallow pits, all of which have much the same characteristics.

Pit of M.R. Birton, $21 / 2$ miles northcast of Marianna-In a sloping hillside twenty feet of the soft chalk-like Mariamna limestone has been quarried for building stone.

Analysis of Limestone in M. R. Burton pit (Survey sample B- -9$)$.

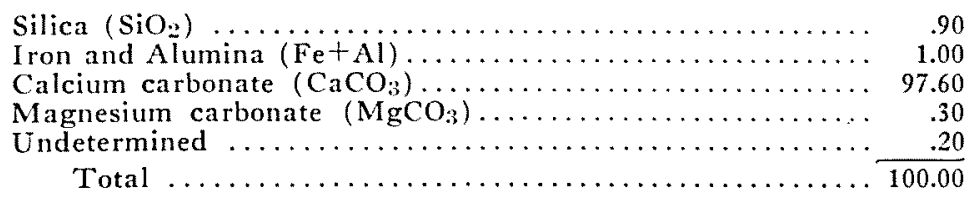

Pit of Philip Scrton, $13 / 4$ miles northeast of Marianna-This is one of the typical shallow pits in which the building blocks are sawed out for local use. Fifteen feet of the Marianna limestone is exposed in a sloping hillside which is covered with red sandy clay.

Analysis of Limestone in Sexton pit (Sureny sample C-54).

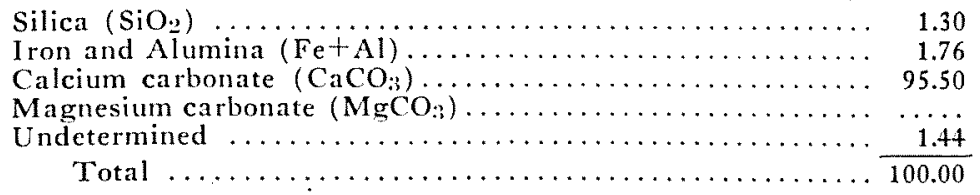

Bluc Spring, $6 \frac{1}{2}$ miles northeast of Marianna-The spring itself probably flows from the underlying Ocala limestone, but in this vicinity the Marianna outcrops through the red sand-clay soil mantle in road cuts, washes, etc. The outcrop is seldon more than two or three feet in thickness.

Analysis of Limestone at Blue Spring (Survey sample C-5o).

\begin{tabular}{|c|c|}
\hline Silica $\left(\mathrm{SiO}_{2}\right)$ & .52 \\
\hline Iron and Alumina $(\mathrm{Fe}+\mathrm{Al})$ & 1.96 \\
\hline Calcium carbonate $\left(\mathrm{CaCO}_{3}\right)$ & 96.50 \\
\hline Magnesium carbonate $\left(\mathrm{MgCO}_{3}\right)$ & 1.00 \\
\hline Undetermined $\ldots \ldots \ldots \ldots \ldots \ldots$ & .02 \\
\hline
\end{tabular}

Between five and seven and a half miles northwest of Marianna, on the Campluellton road, several exposures of the Marianna limestone are 
to be seen where blocks have been cut out. The most northerly of these outcrops is in the roadsicle on the property of J. M. Dekle, $i 1 / 2$ miles from Narianna. The rock here is soft, white and chalky, and shows an exposed thickness of three feet under four or five feet of red sandy clay.

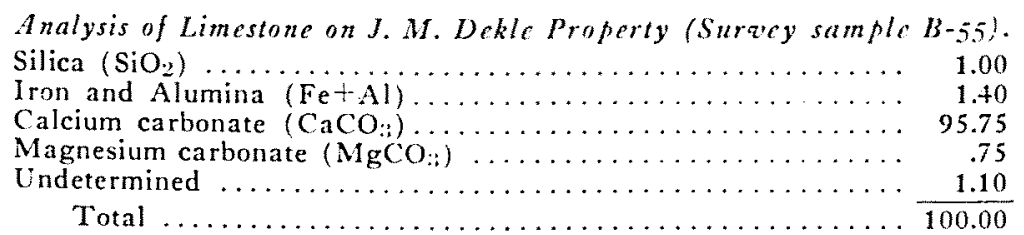

Three miles north of the Dekle property or ten and one-half miles from Marianna and three-fourths of a mile east. on Waddell's Mill Pond, the weathered Ocala limestone can be seen in large boulders standing eighteen to twenty feet above the level of the ponrl. The material is semicrystalline and light brown to gray in color. Deep clefts or caves extend down into the main borly of the rock so that the total observable thickness is about thirty feet. This cleposit is quite accessible to motor transportation and the site is such that a small plant could be locaterl to quarry the rock, which, on account of its chemical purity and physical properties, would be excellent for manufacturing quicklime.

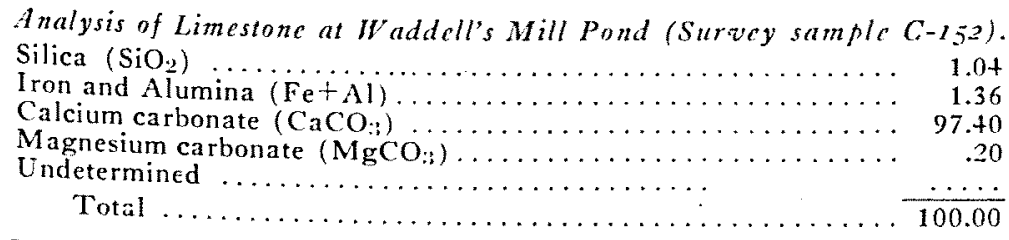

One-half mile farther north or about eleven miles from Marianna. on the Camphellton road, on the property of M. L. Dekle (old Barker place), the Ocala limestone has been quarried to a small extent for chinney stone. The rock is soft and granular, but a little harder and not so even grained or chalk-like as the Marianna, though the method of sawing out blocks by hand is employed with success. The red sandy clay cover here is thin, one to two feet, and the exposed limestone six feet.

Analysis of Limestone on Old Barker Place (Survey sample B-62).

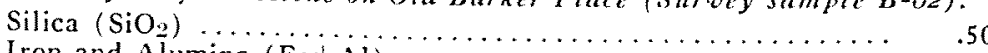

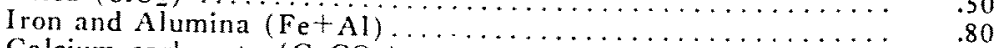

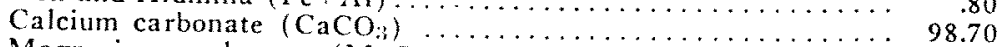

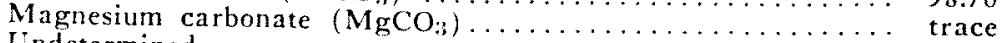

Undetermined

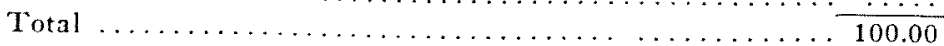


The Marianna limestone does not extend very far westward beyond Cottondale. A few small pits show the presence of the formation to the southwest and northeast of this point.

Property of C. Welsh, onc-half mile cast of Cottondale on $L . \& N$. R. R.-In a gently sloping hillside several shallow ( 2 to + feet) pits have been dug at different levels to cut out the soft Marianna limestone; in all about ten or twelve feet of rock are exposed.

Analysis of Limestone on Welch Property (Survey sample D-15I).

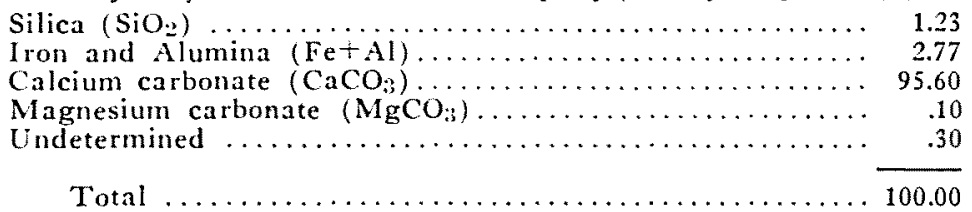

Property of M. A. Spate, $1 \mathrm{1} / 2$ miles north of Cottondale-Eight feet of the chalky soft Marianna limestone is exposed in a small pit where it has been sawed out in building blocks. The pit lies in a large open field with only a few inches to a foot of soil-covering.

Analysis of Limestone in Spate pit (Survey sample B-57).

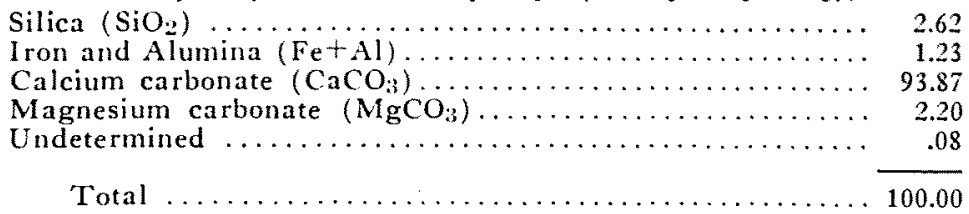

G. H. Cartledge Property-Rabbs Talley-31/2 miles southeast of Cottondale-The county hereabouts is gently rolling and covered with a thick mantle of red sandy clay which masks the underlying limestone: over most of the region, but in this instance a small patch of the Marianna limestone is laid bare in the valley floor.

\begin{tabular}{|c|c|}
\hline Silica $\left(\mathrm{SiO}_{2}\right)$ & 2.14 \\
\hline Iron and Alumina $(\mathrm{Fe}+\mathrm{Al})$ & .02 \\
\hline Calcium carbonate $\left(\mathrm{CaCO}_{3}\right)$ & 97.84 \\
\hline Magnesium carbonate $\left(\mathrm{MgCO}_{3}\right)$. & .60 \\
\hline termined & \\
\hline 10 & 100.6 \\
\hline
\end{tabular}

Natural Bridge on the Chipola Rizer, $3 \mathrm{y} / 2$ miles north of Marianna. The limestone here exposed is mostly the weathered and inclurated phase of the Ocala, but in some sheltered places the typical soit phase is seen. 
The rock outcrops in a low rounded hill eighteen to twenty-six feet high, rising abruptly from the flood-plain of the river. In many places the slope of the hill is gradual with weathered limestone knobs and boulders cropping out beneath the soil and debris, but on the west and northwest sides the hill is flanked by huge sheer-faced boulders ten to fifteen feet in height, exhibiting deep clefts and channels.

The limestone as a whole is much indurated, light brown in color (fiesh face) and much weathered, showing pock marks, and many irregular knobs and pits. Limestone of this type is excellent for burning in the manufacture of quicklime, though the tonnage of hard rock here is probably not enough to warrant large development.

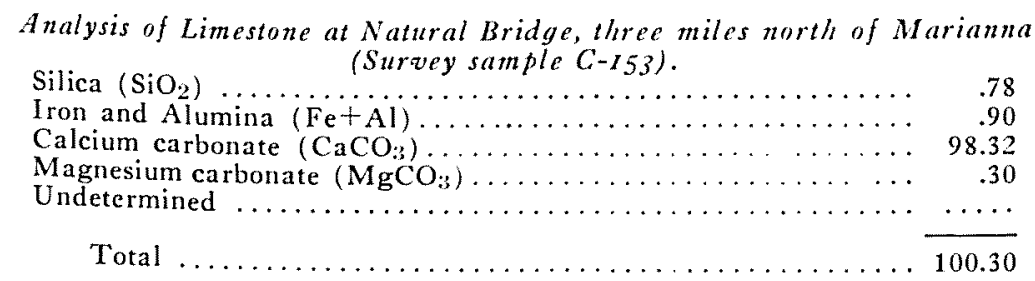

On the property of George Spooner, $21 / 2$ miles north of Sneads, limestone in the form of hard, flinty boulders can be found outcropping on the hillsides just back of the low swampy area bordering the river. The country is well wooded and no accurate section is possible, but in one hill about sixty feet high a solicl bed of limestone outcrops on the highest point and in intermittent boulders all along the hillside. The first sample is from a shallow pit, $1 \frac{1}{2}$ feet deep, dug into the limestone at the top of the hill; this rock is hard and impure, generally tinted a dull olive-brown; in some parts light-green tones are distinguishable. Not enough relatively unweathered material can be seen to form a true idea of the lithology of the deposit, which seems to belong to the Chattahoochee formation.

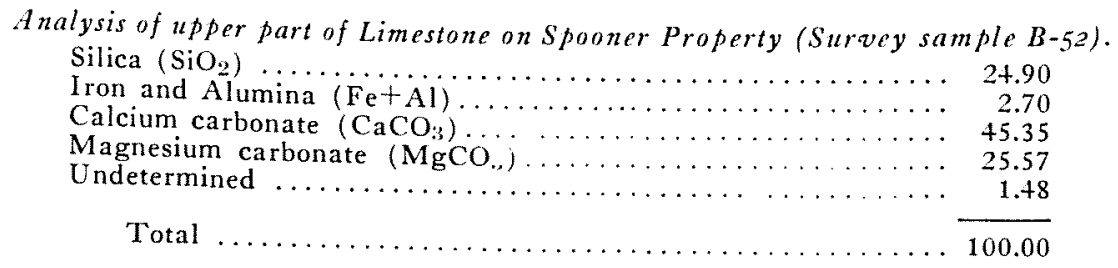

The second sample from the same location was taken from some of the boulders near the bottom of the hill. 
Analysis of Boulders on Spooner Property (Survey sample B-5I).

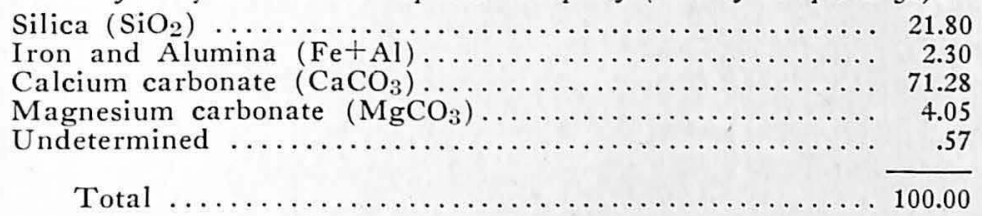

JEFFERSON COUNTY

Jefferson County is in north Florida, extending from the Georgia State line to the Gulf of Mexico. Most of the northern and central portion lies in the Middle Florida hammock belt which includes some rolling red hills, country somewhat similar to the Tallahassee red hills. The northermmost part of the county, as far south as Lloyd, is underlain by the Glendon limestone which is usually masked by the unconsolidated sands and sandy clays of the Alum Bluff formation. Lake Miccosukee and many sink-holes in this area testify to the presence of the limestone, though rock outcrops are extremely rare. In the central part of the county the Alum Bluff is thicker and the limestone has a much smaller effect on the surface topography. The southern portion of the county is very low, flat and in many places quite swampy. A limestone, pre-

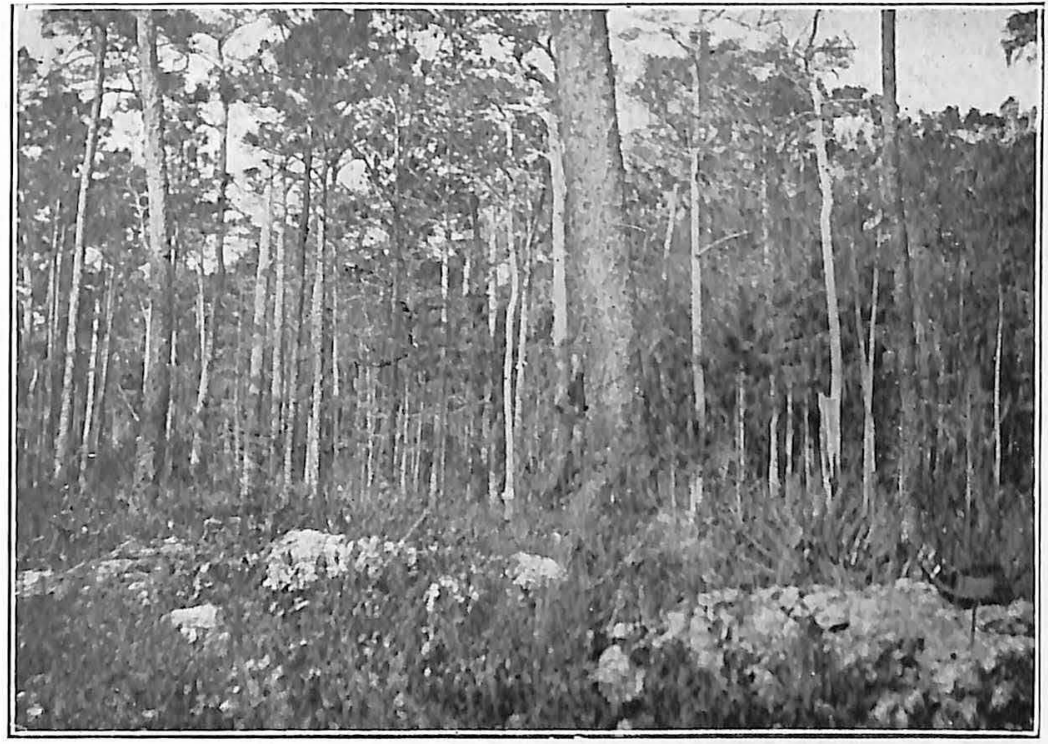

Fig. 39.-Flint rock at the surface in the "Pinhook" section of Jefferson County. 
sumably the same as seen in Wakulla County, is probably present near the surface, but is represented in outcrops by impure flinty boulders. The presence and extent of the pure limestone near Natural Bridge on the Aucilla river (see Taylor County) could not be ascertained because of the inaccessibility of that region at the time visited.

Limestone in the Miccosukee Drain, three miles northeast of Lloyd -At this location the Drain cuts down into the Glendon limestone and for about two hundred and fifty yards forms quite a little ravine. At the deepest cut the stream flows fifteen to twenty feet below the level of the surrounding country. The stream is from six to ten feet wide and flows between sheer faces of the indurated rock; these faces are as a rule six to eight feet high and are topped by twelve to fourteen feet of sand and loam in sloping banks. At one place there is a little rise where the limestone is present almost to the surface; a section taken here shows:

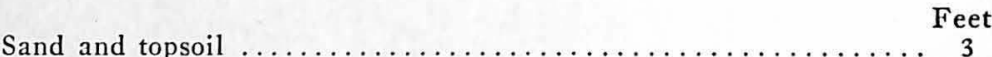

Hard jagred "pock-marked" $\ldots \ldots \ldots \ldots \ldots \ldots \ldots \ldots \ldots \ldots \ldots$

Massive solid limestone to water level ..........................

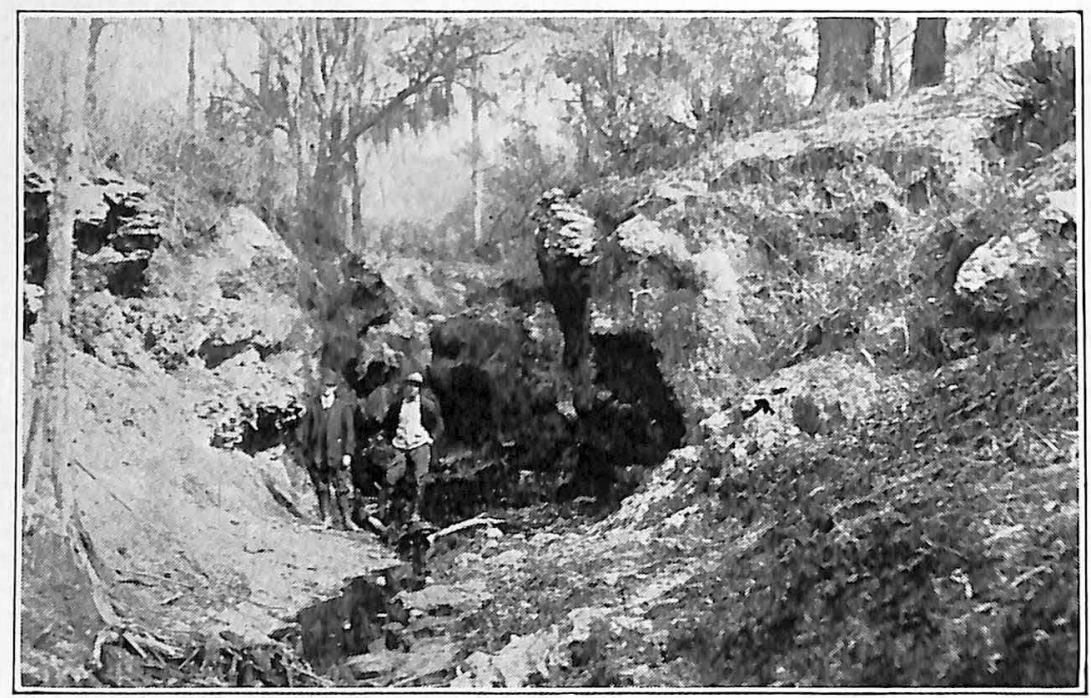

Fig. 40.-Glendon limestone exposed in Miccosukee Drain, $21 / 2$ miles northeast of Lloyd, at low-water stage. 
The limestone is of the Glendon formation, but as a rule that part lying near the stream is more massive than the material nearer the surface which is weathered out in the typical Glendon manner.

The sample from which the following analysis was made was taken about three feet above normal water level. On a fresh face this rock is soft, compact, cream to white in color with a little yellow impure matter scattered irregularly all through it. It has a loose porous texture, not as noticeable as the Chipley material, but does exhibit the "platey" phase seen there.

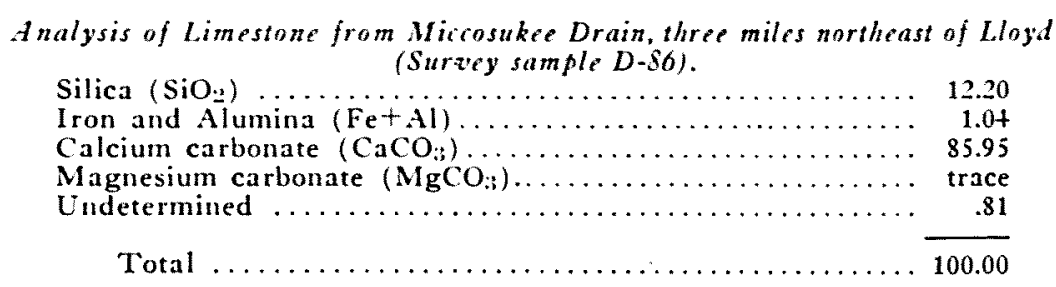

The heavy overburden may retard development in this area, but well-planned prospecting might disclose an acreage with limestone present under a workable cover.

\section{LAFAYLTTE COLNT:}

Lafayette County is quite flat in the southwestern portion, but towards the Suwannee river the land becomes rolling; there are few exposures showing the underlying limestone. Outcrops along the Suwannee river and in Suwannee County to the east and north and along the Steinhatchee river and Dixie County to the south indicate that the Ocala limestone is present at no great depth in the northeastern three-fourths of the county. In the remaining western portion a limestone of unknown age (probably Lpper Oligocene or Lower Miocene) lies under a somewhat heavier solid mantle; residual Hinty boulders of this formation are frequently encountered near the surface, but the main borly of the rock lies deeper.

\section{LAKE COUN'TY}

The whole of Lake Comnty, in central peninsular Florida, lies in the Lake Region and the surface formations are mostly red sandy clays and sands of undetermined age, except in the eastern part along the St. Johns river, where the Nashua marl is present, covered by variable thicknesses of light-colored Pleistocene sands. Lnderlying all these are the shell marls, sands and clays of the Alum Bluff group. 


\section{LEE COUN'IY}

Lee County is on the Gulf coast in southern Florida and is very flat. In the northern portion along the Caloosahatchee river, the marl of that name outcrops over a considerable area. The rest of the county is underlain by shell marls or thin limestones of Pleistocene age, covered by sand. In the southeastern part this sand mantle may be as much as eight or ten feet thick, but in the region south of Fort Myers it seems much less than this. Drainage canals $/ 1 / 2$ and 10 miles south of that city have cut into four or five feet of shell marl under a thin sand cover of only three to four feet; most of the marl is unconsolirlaterl and composed of shell and light yellow sand, but in some places is quite compact, and by redeposition, altered to a thin, hard, brittle linestone, slightly impure.

This marl has not been extensively cleveloper, but would be quite valuable in local road construction.

\section{LRON COUNTY}

Leon County lies in middle Florida east of the Ocklocknee river. The oldest exposed formation is a limestone of 1 mknown age (formerly called Chattahoochee), but in all probability closely related to the Chipola marl or the Glendon. This limestone outcrops at the surface all through the low southern part of the county and is exposed occasionally in lime-sinks, stream beds and lake basins to the north line of the county. Overlying this are the sands and clays of the Alum Bluff. particularly well exposed in the high red hill area about 'Tallahassee. At Jackson's Bluff on the Ocklocknee river and in some tributaries to that stream in the northwestern portion of Leon County, the Choctawhatchee marl is found.

In grading the main highway between Tallahassee and Wakulla in the ricinity of Woodville, boulders of limestone were lug out from a depth of two to three feet. This rock is compact and hard, often locally semicrystalline and has given satisfaction in local road building.

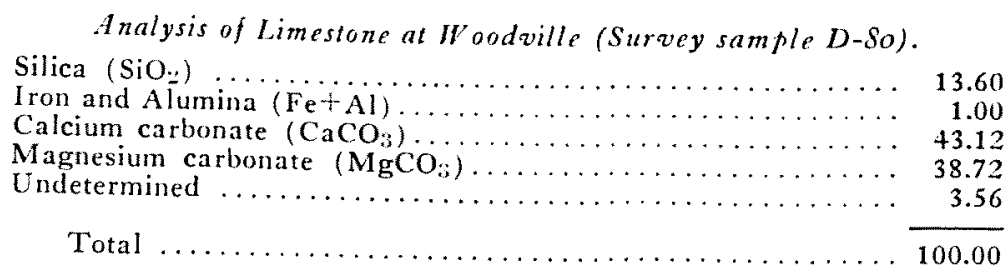




\section{LEVY COUNTY}

Almost the whole of Levy County, lying on the Gulf in the northcentral part of peninsular Florida, is immediately underlain by the Ocala limestone with a thin overburden of Pleistocene sands. In places thin sands and clays of the Alum Bluff group or clays of later age rest on the limestone over small areas and in the northeastern portion of the county (lime-sink region) phosphate has been deposited locally in the limestone. Along the eastern edge of the county, around Williston, Montbrook and Morriston, the upper two to five feet of limestone has been altered in irregular patches to an impure flint and has given rise to a local crushed hard-rock industry. (See "General Summary.")

Pit of Florida Shell Rock Co. (E. A. Osborne), two miles north of Williston-This is the only lime pit operating in this vicinity, although through this entire section excellent deposits of limestone are present. The overburden is red-brown sand and clayey loam varying in thickness from a few inches to two feet; the rock itself is quarried to a depth of thirty-eight feet. The limestone is the typical soft, pure Ocala, but seems slightly more compact and breaks with a rough, jagged face instead of crumbling to a powder as is often the case in this soft formation. Irregularly throughout the pit slightly harder masses occur, but not of sufficient hardness to interfere with the crushing, which is done by means

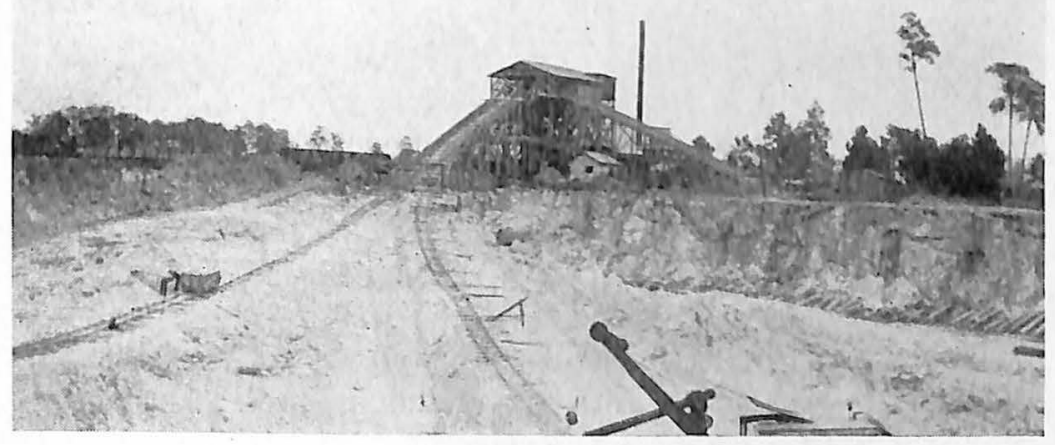

Fig. 41.-Ocala limestone. Pit and crusher of Florida Shell Rock Company, Williston. 
of the usual roller crushers. No flint is encountered and only a very few shallow clay pockets are present. The entire output is used in highway construction.

Analysis of Limestone in Osborne pit, Williston (Survey sample C-24).

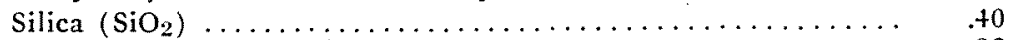

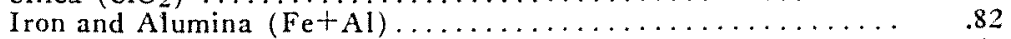

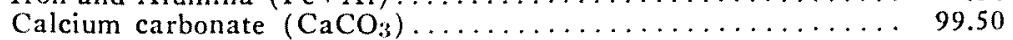

Magnesium carbonate $\left(\mathrm{MgCO}_{3}\right) \ldots \ldots \ldots \ldots \ldots \ldots \ldots \ldots \ldots \ldots$

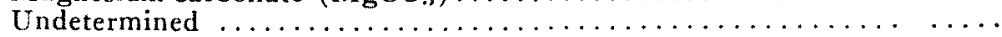

Total

100.72

Results of 16 analysis from the Osborne pit by the T'esting Division of the State Road Department:

$\begin{array}{lccc}\text { Silica }\left(\mathrm{SiO}_{2}\right) \ldots \ldots \ldots \ldots \ldots \ldots & \begin{array}{c}\text { High } \\ 6.62\end{array} & \text { Low } & \text { Average } \\ \text { Calcium carbonate }(\mathrm{CaCO}) \ldots & 99.10 & 92.50 & 1.86 \\ \text { Magnesium carbonate }(\mathrm{MgCO} ;) & .80 & .30 & 97.50 \\ \end{array}$

\section{LIBERTY COUNTY}

Liberty County is located in middle Floricla, just east of the Apalachicola river. The extreme northern country (in the West Florida pine hills) is quite high, and the river has carverl out steep bluffs in which, under a thick surficial deposit of sand, are exposed the deeperlying formations. Except for this extreme northern region, the county is rather low flatwoods (Apalachicola flatwoods), in which outcrops are masked by the thick sand mantle; some small exposures are seen in the stream beds, but in an area of slight relief even these are necessarily thin. In river bluffs in the northern part, the Chattahoochee limestone is exposed, particularly in Rock Bluff where it is overlain by thick Miocene marl, and in some smaller exposures on tributary streams. At Alum Bluff, under seventy feet or so of red and yellow sands, the Choctawhatchee marl is exposed overlying sands and clays of the Alum Bluff group, at the base of which, during low-water periods, the Chipola marl can be seen extending down below the water. Farther south in the county recognizable formations are nowhere exposed except the Choctawhatchee in a few localities on the Ocklocknee river, the eastern border of the county, at Jackson's Bluff, and some localities on smaller streams in the central part of the county. The heavy overburden and limited exposed areas of the marl made commercial exploitation quite inprobable, but some use might be made on a small scale where an exposure could be worked to supply marl as a soil corrective for local use. 


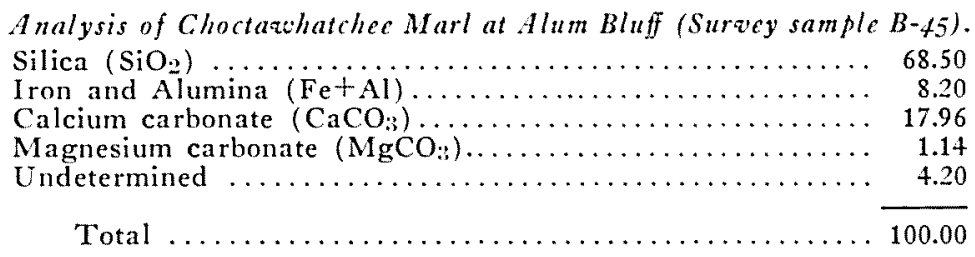

The high "undetermined" suggests a small quantity of phosphate or other plant food. Ammonia, potash and phosphate in small quantities have been found in this marl.

\section{MADISON COUNTY}

Madison County borders the Georgia State line and lies west of the Suwannee and Withlacoochee rivers, mostly in the lime-sink region. In the sontheastern portion the Glendon limestone lies at or near the surface, concealed by thin Pleistocene sands or sands and clays of the Alum Bluff group; these latter beds grow thicker to the north and entirely mask the limestone except in a few instances where it outcrops in sink-holes or lake basins. In the country lying near the rivers the limestone is very near the surface, as at Lee, where hard semicrystalline rock was struck at a depth of seven feet in a pit from which red sandy clay was being dug for road material. All along the banks of the main streams limestone is exposed, as at Ellaville (see Suwannee County), and Bellville (see Hamilton County).

\section{MANATEF, COUNTY}

In the northwest corner of Manatee County, on the Gulf coast in southern Florida, the sands, clays and fuller's earth beds of the Alum Bluff group are exposed at the surface, but elsewhere these deposits are buried beneath those of younger age, chiefly Pliocene. In the northeastern portion these Pliocene beds are closely related to the phosphatic Bone Valley formation, but over the southern and southeastern area the Pliocene is represented by the Caloosahatchee marl. Nearer the coast the Pleistocene shell marls are present, though thin, and are exposed in drainage ditches between Sarasota and Bradenton and in road material pits near the latter place. In the vicinity of Bradenton the marls have undergone redeposition and form a hard, light, buff-colored, sandy limestone, often laminated, that weathers into peculiar shapes. 


\section{MARION COUNTY}

Marion County lies in the central part of the peninsula and is by far the leading lime-producing area of Floricla. The eastern part is in the Lake Region, and is mostly sandy scrub, underlain by the sands and sandy clays of the Alum Bluff, and the western part by the Ocala limestone. The Ocala outcrops at the surface or uncler a shallow mantle of sand, nowhere more than six feet and usually about one or two. The industry centers around the city of Ocala. The Floricla Lime Company's pit number one (No.1) on the southern edge of the town, and the Ocala Lime Rock Company's pit number two (No. 2), now abandoned (formerly the Weblo property), five miles north, are the oldest lime pits in the State, having been operated for the past thirty-five years. These were primarily used for manufacturing building and agricultural lime, but in the last few years, since the Ocala limestone has proved so adlaptable as road material in State highway construction, there have sprung up in this vicinity many new companies equipped for this sole purpose, so that now most of the production goes into road-building, though other uses are not slighted.

Ocala Limestonc-Since all the pits in Narion County are in the Ocala limestone, which is very uniform in this area, and to avoid unnecessary repetition in each separate section given, it has been thought best to give here a description of the limestone and the general features encountered in all the pits, along with something of the mining methods, and any differences or departures from the typical occurrence will be cited where they appear.

The Ocala is a very soft, pure, cream-white, granular, porous limestone. It is remarkably uniform in appearance and physical properties, though there may be small chemical differences in various localities. Usually it is so soft that a lump may be crumbled in the hand; masses of harder material occur irregularly both in size and position in the section in all pits. These may be the semiconsolidation of the limestone about masses of fossil shells, which occur throughout in the greater profusion (sometimes the whole body of limestone is made up of them), or it may be the result of water percolating through and bringing about this irregular semiconsolidation. These harder spots show no difference in color, and are easily broken up in the roller crushers and readily pulverized by steam rollers when laid down in building a highway. These harder masses in the main body of the formation must not be confused with the 


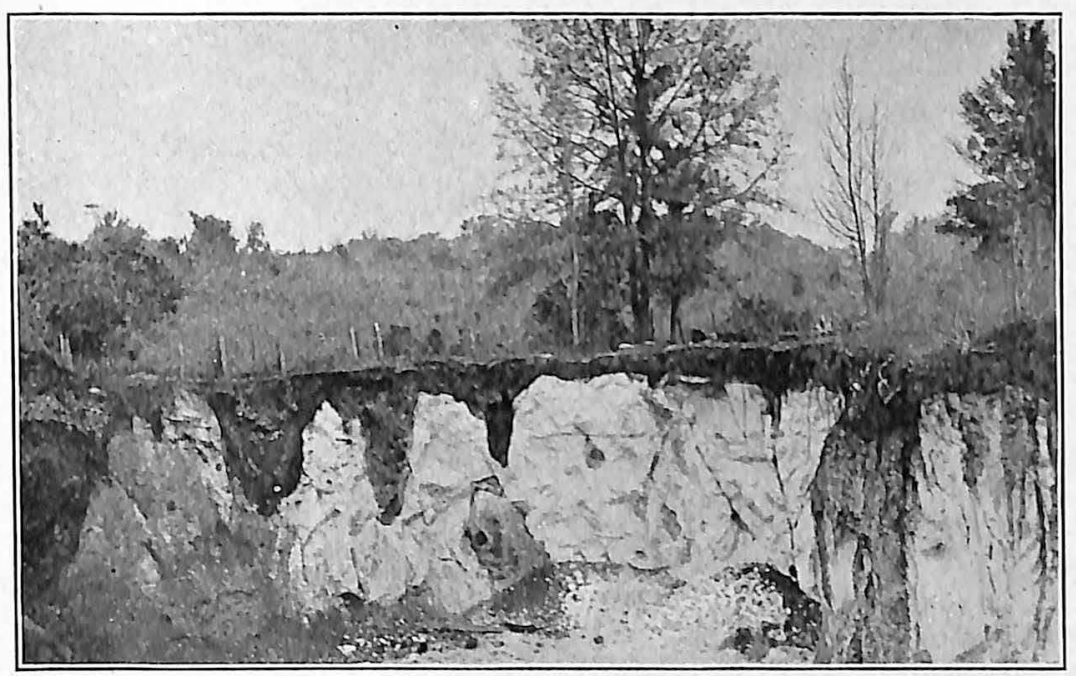

Fig. 42.-Pit of Florida Lime Company, Ocala.

weathered, indurated surface layer so often encountered, which is much harder and more brittle. Layers or boulders or flint occur in many of the pits, but usually in no quantity, and are thrown aside. Old solution channels a few inches wide and "pot-holes" filled with clay, sand and debris are found throughout the area, but also in no great quantity. These may extend twenty to twenty-five feet down and, in the case of the "potholes," may be as much as twenty-five to thirty feet in diameter ; if small they are dug out by hand, if large are mined around and by blasting thrown to the bottom of the pit. All the mining is open pit-work; the residual sand and soil are stripped off by steam shovels and the pit started. Sometimes the rock is so soft that the shovels can scrape it from the face, but usually the rock is blasted in situ and thus the face is fractured and loosened to expedite the work of the shovel. The rock is then loaded on small dump cars and hauled by cable to the crusher, though much of it is already in powdery form or in small rock fragments to pass the required mesh; because of the softness of the rock simple roller crushers are used. After passing through the crusher the rock is loaded by a gravity chute on railroad cars for shipment. Most of the lime pits work the rock to a depth of thirty-five or forty feet, because at this depth the water table is struck, below which no quarrying 
is done. The Florida Lime Company number three pit at Zuber is located on higher ground and worked to a depth of fifty-five or sixty feet, thus exposing the greatest thickness of rock in this area. The exact thickness of the Ocala is unknown, but may be as much as one hundred and fifty to four hundred feet.

Cummer Lumber Company pit, five miles north of Ocala, near Kondrick-

Section:

Gray sandy loam.

Feet. Inches.

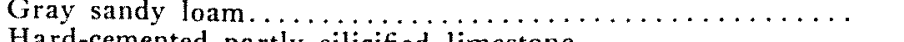

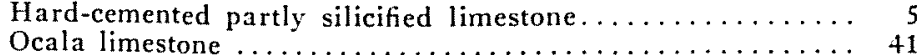

The hard limestone capping this deposit is umusual. Owing to exposure to rain and general weathering conditions the top foot or so of the Ocala is usually hard and indurated, but not as much as in this instance, and is not silicified. This capping limestone is in the form of large boulders rather than a solid bed. A layer of flint about six inches thick of considerable extent is encountered in the lower part of the section in the south and east end of the pit and both this and the hard top limestone are crushed in a hard-rock crusher and sold as concrete material and railroad ballast.

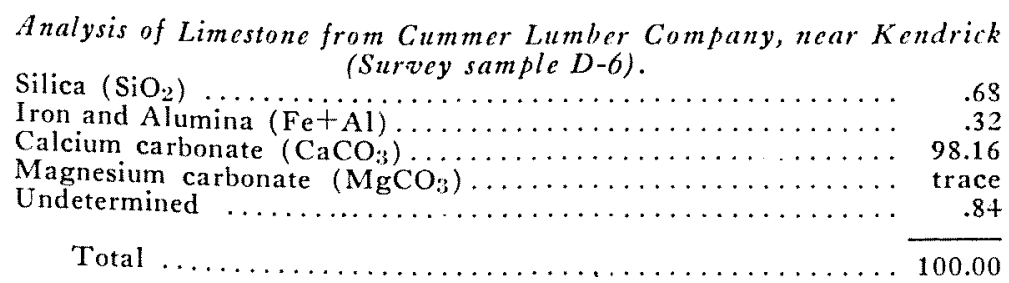

Results of four analyses of this limestone by the Testing Division of the State Road Department:

\begin{tabular}{|c|c|c|c|}
\hline & High & Low & Average \\
\hline $\begin{array}{l}\text { Calcum carbonate }\left(\mathrm{CaCO}_{3}\right) \\
\text { Magnesium carbonate }\left(\mathrm{MgCO}_{3}\right) \\
\left.\text { Silica ( } \mathrm{SiO}_{3}\right)\end{array}$ & 99.20 & 97.15 & 98.47 \\
\hline Iron and Alumina $(\mathrm{Fe}+\mathrm{Al})$ & 3.02 & .86 & 1.66 \\
\hline
\end{tabular}

Pit of Ocala Lime Rock Company, No. 1, at Kendrick, 51/2 miles north of Ocala-

Section:

Light-brown clayey sand $\ldots \ldots \ldots \ldots \ldots \ldots \ldots \ldots \ldots, 4$ to 5 feet

Ocala limestone 


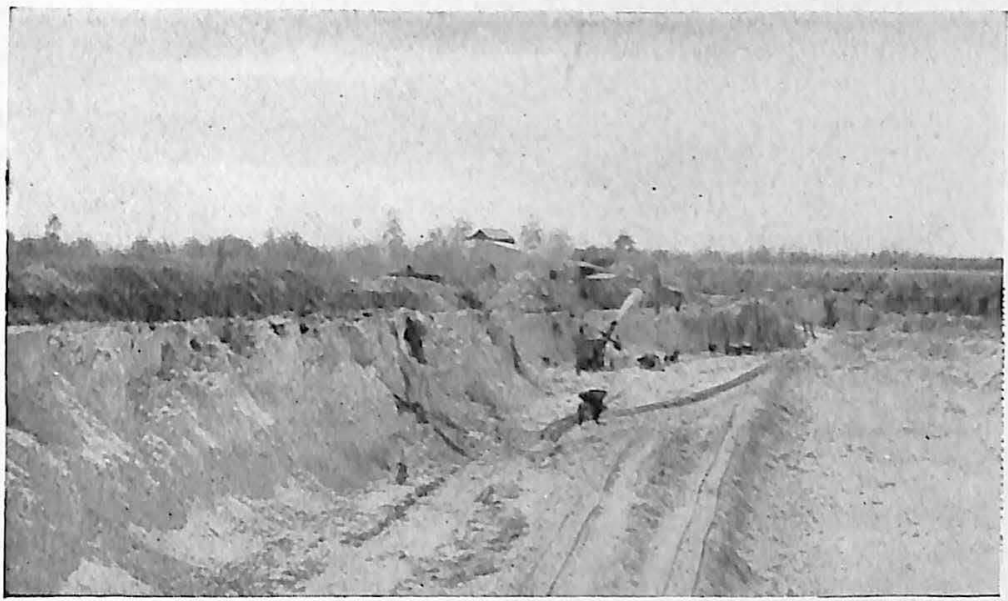

Fig. 43.-Ocala limestone in Ocala Lime Rock Company pit, Kendrick.

This large pit produces very high-grade rock exclusively for road materiai. The limestone is the typical soft Ocala with occasional clay pockets and, toward the base of the deposit, a little flint.

Analysis of Limestone from Ocala Lime Rock Co., Kendrick (Survey sample D-8).

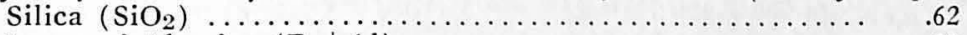

Iron and Alumina $(\mathrm{Fe}+\mathrm{Al}) \ldots \ldots \ldots \ldots \ldots \ldots \ldots \ldots \ldots \ldots \ldots \ldots \ldots \ldots \ldots \ldots \ldots, 28$

Calcium carbonate $\left(\mathrm{CaCO}_{3}\right) \ldots \ldots \ldots \ldots \ldots \ldots \ldots \ldots \ldots \ldots . \ldots \ldots . \ldots \ldots$

Magnesium carbonate $\left(\mathrm{MgCO}_{3}\right) \ldots \ldots \ldots \ldots \ldots \ldots \ldots \ldots \ldots \ldots \ldots \ldots \ldots$ trace

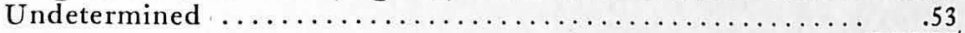

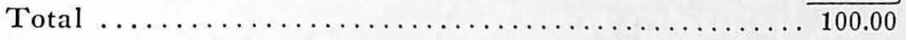

Commercial Lime Company at Reddick-

Section:

Feet. Inches.

Red-brown clayey sand $\ldots \ldots \ldots \ldots \ldots \ldots \ldots \ldots \ldots \ldots, 3 \ldots \ldots \ldots$

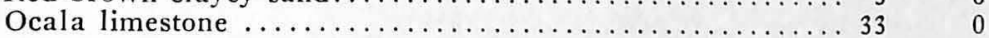

Analysis of Limestone from Commercial Lime Company, Reddick

(Survey sample D-7).

(Survey sample D-7).

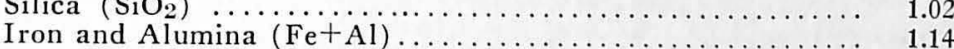

Calcium carbonate $\left(\mathrm{CaCO}_{3}\right) \ldots \ldots \ldots \ldots \ldots \ldots \ldots \ldots \ldots \ldots \ldots \ldots \ldots \ldots \ldots .78$

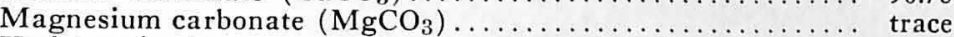

Undetermined .................................... 1.06

Total ......................... $\overline{100.00}$

This company operates a battery of ten kilns, total capacity five hundred barrels per day, and burns the material from this pit in the manufacture of commercial lime. 
Florida Lime Company, pit No. 3, at ZubcrSection:

Feet. Inches.

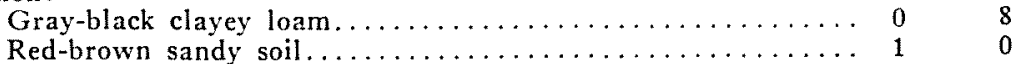

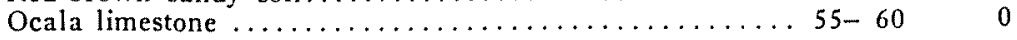

Analysis of Limestone from Florida Lime Company pit No. 3 at Zubor (Survey sample $C-5)$.

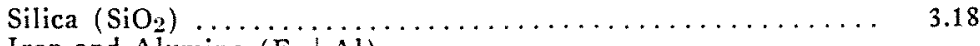

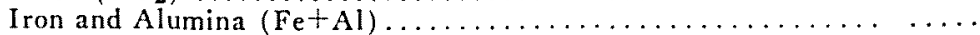

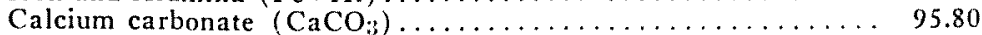

Magnesium carbonate $\left(\mathrm{MgCO}_{3}\right) \ldots \ldots \ldots \ldots \ldots \ldots \ldots \ldots \ldots \ldots \ldots$

Undetermined $\ldots \ldots \ldots \ldots \ldots \ldots \ldots \ldots \ldots \ldots \ldots \ldots \ldots \ldots, 1.02$

Total

100.00

The limestone from this deposit is burned in the manufacture of commercial lime.

The Ocala Lime Rock Company, pit No. 3, at Santos-Thirty-three feet of the Ocala limestone is worked here under a two-foot six-inch cover of brown sandy loam. This is a very fine deposit, free from flint and with only a few clay pockets. It is quarried for road material.

Analysis of Limestone from Ocala Lime Rock Co., Santos (Survey sample C-II).

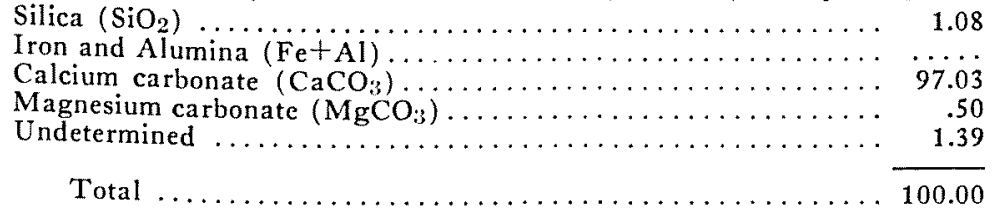

Result of 17 analyses by the Testing Division of the State Road Department :

\begin{tabular}{lrrr} 
High & \multicolumn{1}{c}{ Low } & Average \\
Calcium carbonate $\left(\mathrm{CaCO}_{3}\right) \ldots \ldots$ & 98.95 & 94.00 & 97.86 \\
Magnesium carbonate $\left(\mathrm{MgCO}_{3}\right) \ldots \ldots$ & .90 & $\ldots \ldots$ & .90 \\
Silica and insolubles $\left(\mathrm{SiO}_{2}\right) \ldots \ldots \ldots$ & 2.82 & .70 & 1.63
\end{tabular}

About one mile west of Santos, the county has opened up a pit to supply, locally, road material. At the time visited the pit had only been open a short time and showed a ten foot face under an eighteen inch sand and loam overburden. It was in the typical soft, white pure Ocala.

Florida Lime Company, pit No. 2, one mile southeast of OcalaSection:

Dark-gray sand and loam, roots, etc..............

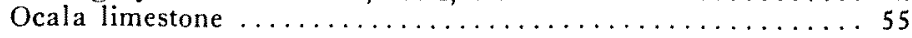

Inches.

550


The material in the east end of the pit is the typ:cal soft, pure Ocala limestone, though it has a deeper cream color than usual. In the west end of the pit the material is coarser, harder and made up almost completely of small fossil shells (foraminifera). It is reported to be even purer than the general run. The output of this pit goes into agricultural and commercial lime.

Analysis of Limestone, Florida Lime Co., No. 2, Ocala (Survey sample D-12).

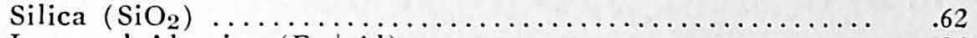

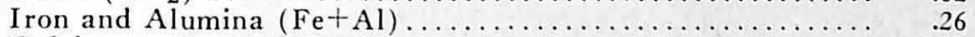

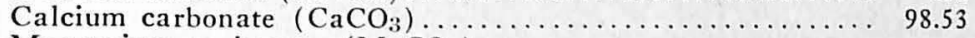

Magnesium carbonate $\left(\mathrm{MgCO}_{3}\right) \ldots \ldots \ldots \ldots \ldots \ldots \ldots \ldots \ldots \ldots \ldots$

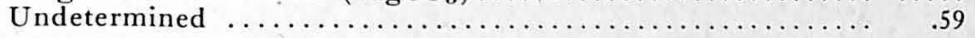

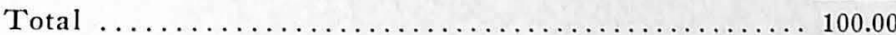

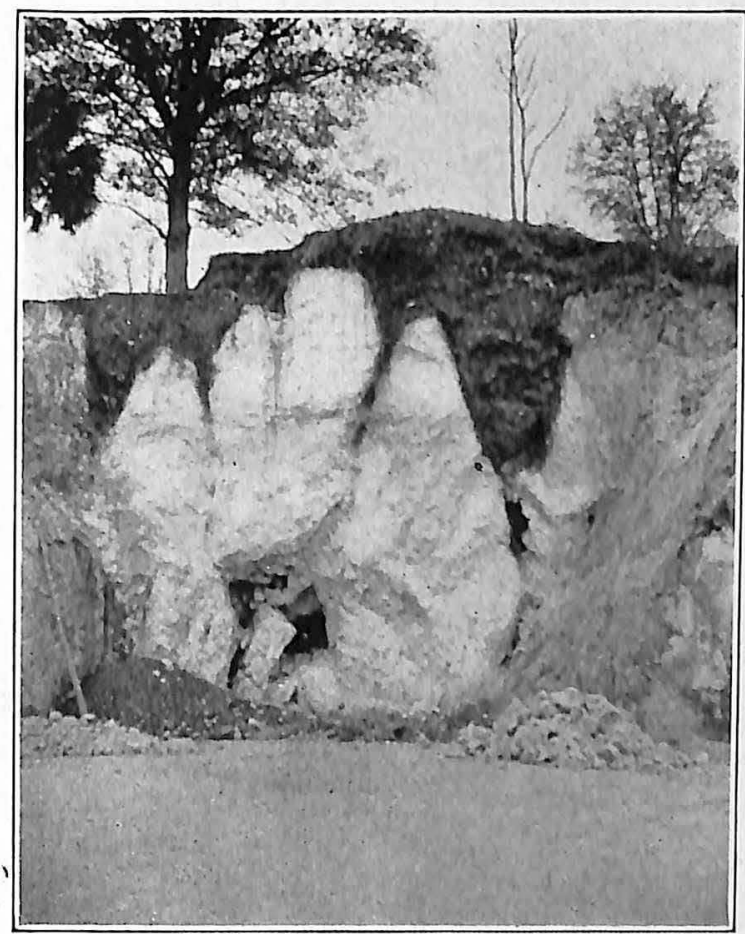

Fig. 44.-Florida Lime Co., pit No. 2, (old Oakhurst quarry), Ocala.

Marion County Lime Company, 2 miles southwest of Ocala-Here the pure Ocala outcrops at the surface and is mined to a depth of forty- 
five feet without overburden. The material is very purc, soft and easily handled; this pit is one of the largest producers of road material in this vicinity.

Analysis of Linestone, Marinn County Lime Company, Ocala (Surercy sample C-If).

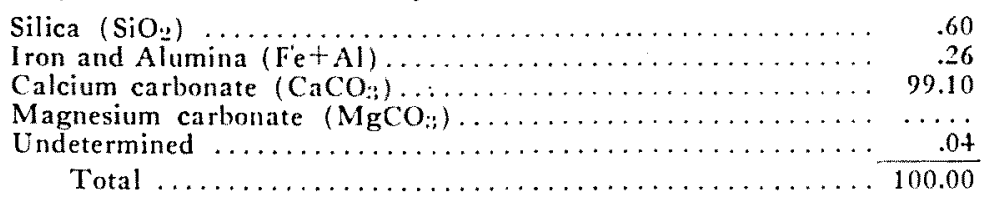

Results of 20 analyses of T'esting Division of the State Road Department :

$\begin{array}{lrrr} & \text { High } & \text { Low } & \text { Average } \\ \text { Calcium carbonate }\left(\mathrm{CaCO}_{3}\right) \ldots \ldots & 99.00 & 92.90 & 97 .+4 \\ \text { Magnesium carbonate }\left(\mathrm{MgCO}_{3}\right) \ldots . & .95 & .10 & .61 \\ \text { Silica and insolubles }\left(\mathrm{SiO}_{2}\right) \ldots \ldots \ldots & 5.88 & .84 & 2.05\end{array}$

\section{Section:}

Florida Lime Company, pit No. 1, Ocala-

Light brown-red clayey sand $\ldots \ldots \ldots \ldots \ldots \ldots \ldots \ldots \ldots$ 2 to 5 feet

Hard, slightly "dirty" Ocala limestone.............. 29 feet

The limestone here is different from the true Ocala, being harder and of a darker color. The hardness seems due in large part to the cementing of the limestone about masses of fossils which occur in large numbers. The chief cause of the impure appearance, as well as the unusual hardness, is the great number of vertical solution channels, stained with clay and clebris, that run all through the limestone. The rock around these channels and small caverns is pitted, honeycombed and hardened by the downward percolating waters. Though this limestone is slightly darker in color and harcler than the usual dazzling white soft Ocala, it seems no less pure chemically when the clay, etc., is removed. It is burned in the manufacture of commercial lime.

Analysis of Limestone, Florida Lime Co., fit No. 1, Ocala (Survey sample D-13).

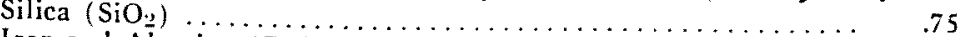

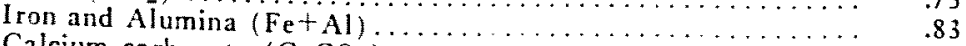

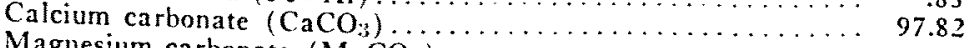

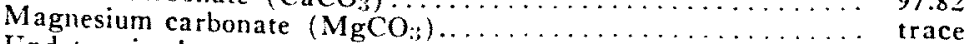

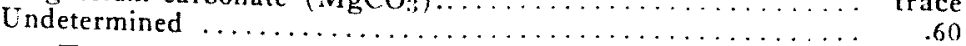

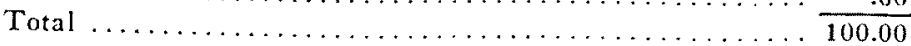

Blowers Lime and Phosphate Company, $21 / 2$ miles north of OcalaSection:

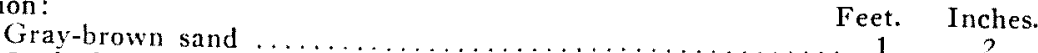

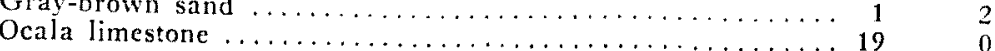


This material is dried, pulverized and used in making an asphalt filler. This company has recently opened a new plant just southwest of Ocala.

Another source of road material in Marion County is the fresh water shell mounds on the west shore of Lake George. These mounds are composed of thin shelled fresh water snails, etc.; some mounds are as much as twenty-five feet in thickness and extend over several acres. The Lake George Shell Corporation at Astor are the only producers in the county, though many individuals have worked these mounds for local use in the St. Johns river valley.

\section{MONROE COUNTY}

Monroe County is the southernmost county in Florida and includes all the Florida Keys from Key Largo southward. Most of that portion on the mainland lies within the Everglades and mangrove swamps, and there is little definite knowledge of the surface formations present. All are of Pleistocene and Recent age, however, and include thin freshwater and marine limestones and marls. In the extreme southern part of the mainland, near East Cape Sable, the Miami oolite lies at a depth of six to eight feet under a dark sandy marl.

On the Keys there are two formations exposed, disregarding sands or thin residual soils, the Key Largo limestone and the Key West oolite. The former outcrops on nearly all the Keys from Key Largo to Marathon and the latter on the Keys west of Bahia Honda Channel. The Key Largo is well exposed in the long series of railroad cuts on the

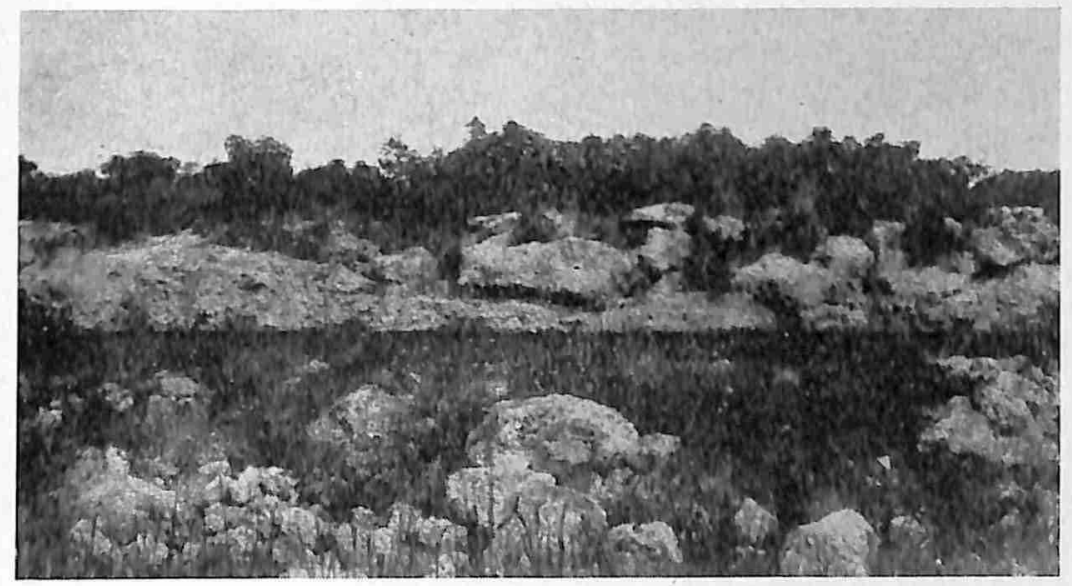

Fig. 45.-Key Largo limestone in old quarry, Windlys Island. 
Key of that name and in the old quarry on Windlys Island to the south. The limestone was quarried to a depth of eleven feet at that locality and used as railroad ballast, and some of it has been used locally in building or house foundations.

Analysis of Limestone on Windlys Island (Survey sample C-Io8).

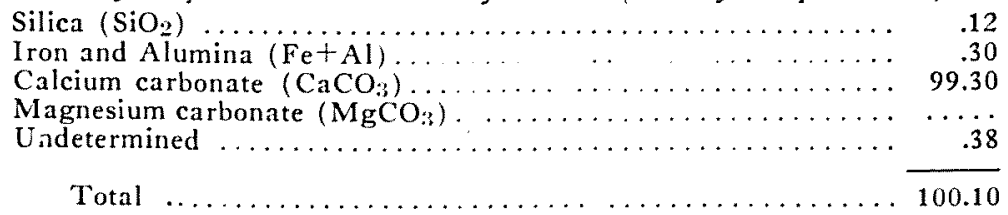

This sample included part of a coral head, which doubtlessly raised the $\mathrm{CaCO}$ s content above the average. Even excepting this, however, the rock is exceedingly pure.

The same formation is exposed at the surface all over Marathon Key; the following sample was taken about one hundred yards north of the ticket office where the rock had been blasted away to a depth of three or four feet in grading the railroad. Here the limestone is closely cemented and very hard.

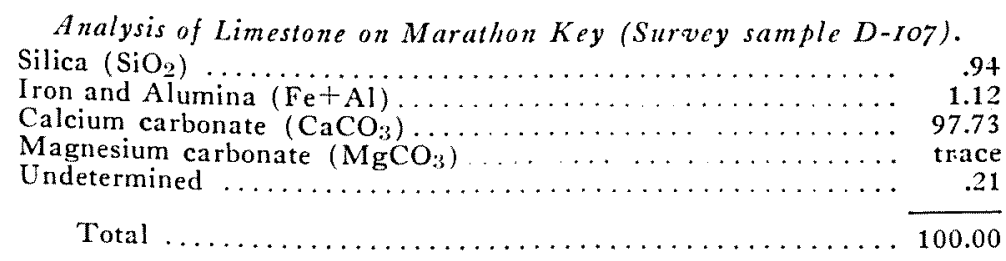

The second formation seen in this area, the Key West oolite, outcrops on the Keys west of Marathon Key. These are quite low lying and good clear exposures are not plentiful; along the beach and near Casa Marina on Key West this limestone outcrops down to the water's edge. The following sample was taken at this location from a shatlow pit one to two feet deep.

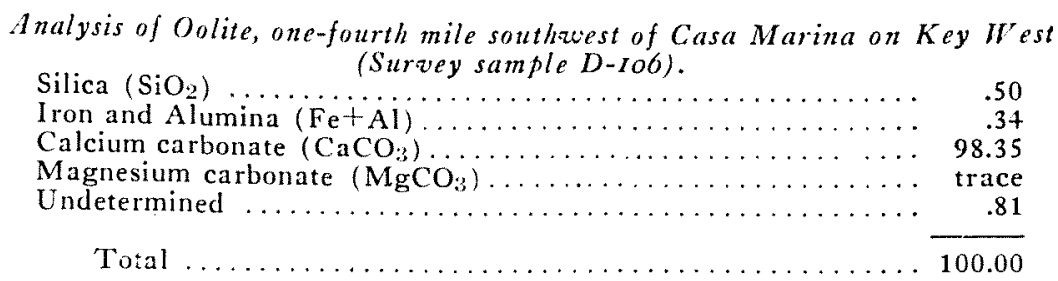


That section of Monroe County occupied by the Keys has good deposits of high-grade limestone, but the low relief, small area, transportation difficulties and distance to markets, retards development almost to the point of impossibility. Key Largo is the best field for a quarry. for there all the drawbacks are reduced to a minimum for this region. The rock is suited for railroad ballast, highway construction, building stone (rather limited use) and in the manufacture of quicklime.

\section{NASSAU COUNTY}

The surface formations of Nassat County, in the extreme northeastern part of Florida, are of Pleistocene and Pliocene age and consist of sands and clays. No lime deposits are known to occur near the surface.

\section{OKALOOSA COUNTY}

Okaloosa County, in West Florida, is almost entirely underlain by unconsolidated sands and some clays of Pleistocene and perhaps Pliocene age. In the northern part the Alum Bluff marls are exposed in some of the stream beds. At Stuart's Mill. Oak Grove, on the Yellow river, the Oak Grove sand can be seen; this formation consists of slate-blue to brown sand with a great profusion of fossil shells. This formation is relatively thin, of small areal extent and probably of no commercial value.

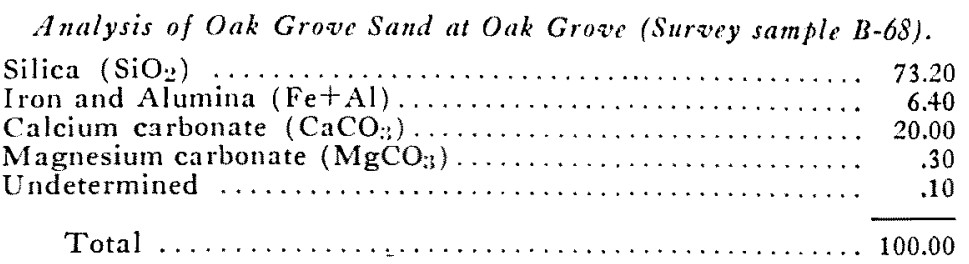

About $21 / 2$ miles northeast of Oak Grove at 'Tanner's Grist Mill on Senterfitt creek, one to two feet of the Oak Grove sand is exposed above the stream under a three to six-foot overburden of red-yellow sand. The marl has a bluish-brown sandy matrix with masses of fossil shells. Its principal use would be as a soil corrective for local use; some small amount of phosphate is probably present, as indicated by the "undetermined" and the fact that similar marls at other localities are slightly $(. .5 \%-1.5 \%)$ phosphatic. 
Analysis of Oak Grove Sand at Tanner's Grist Mill (Survey sample B-7o).

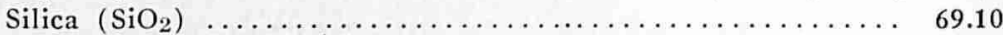

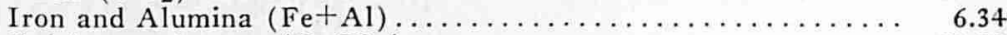

Calcium carbonate $\left(\mathrm{CaCO}_{3}\right) \ldots \ldots \ldots \ldots \ldots \ldots \ldots \ldots \ldots \ldots \ldots \ldots, 21.88$

Magnesium carbonate $\left(\mathrm{MgCO}_{3}\right) \ldots \ldots \ldots \ldots \ldots \ldots \ldots \ldots \ldots, 1.03$

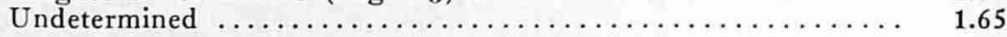

Total $\ldots \ldots \ldots \ldots \ldots \ldots \ldots \ldots \ldots \ldots \ldots \ldots \ldots \ldots \ldots \ldots, \overline{100.00}$

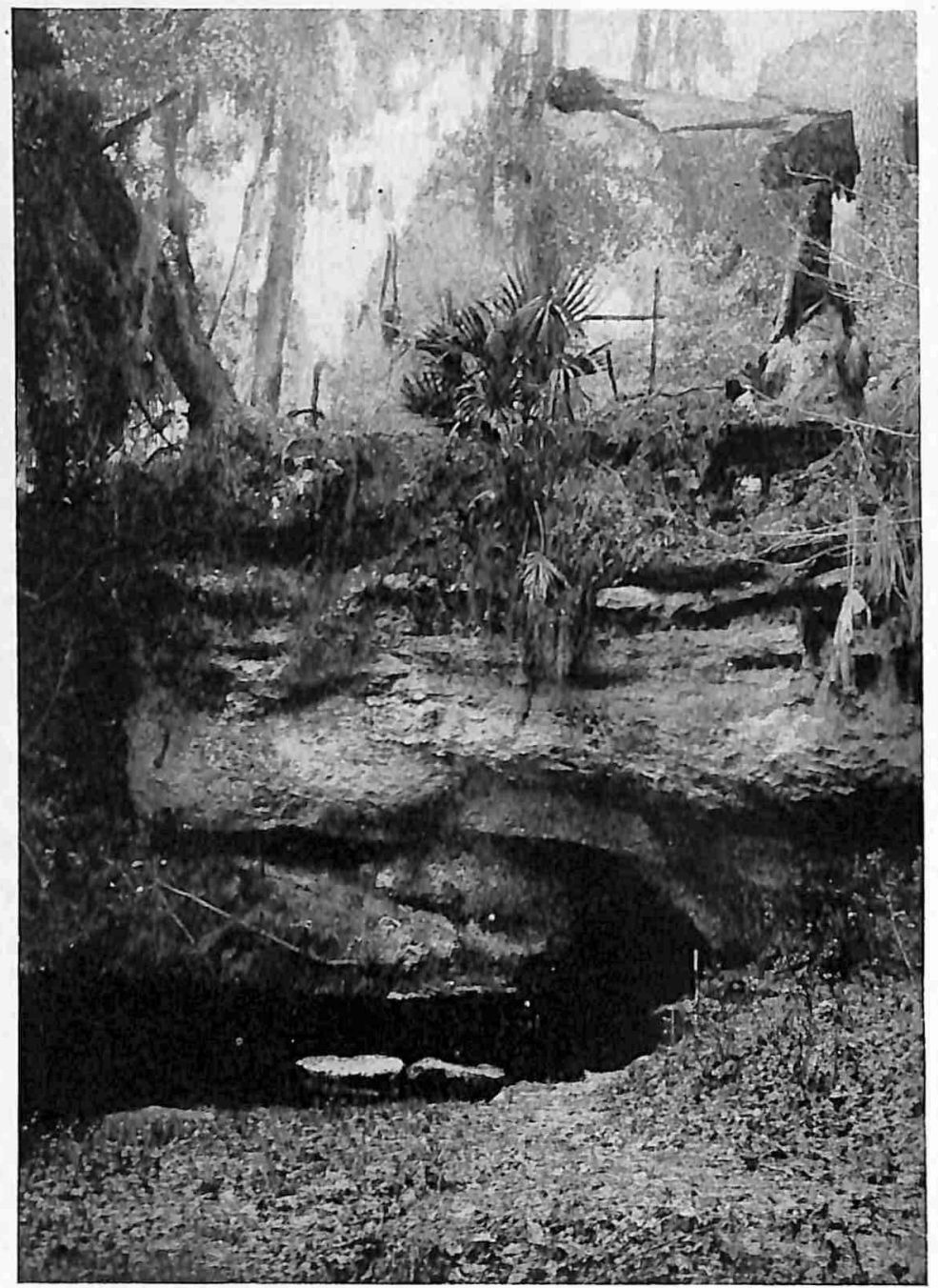

Fig. 46.-Rock Spring, Orange County. 


\section{OKFECHOLFE COUNTY}

Okeechobee County lies in the southern portion of the peninsula, east of the Kissimmee river and north of Lake Okeechobee. The country is very flat and affords few exposures: the Caloosahatchee marl probably underlies the portion bordering the lake, but is covered by a heavy mantle of sand. Some marls of younger age (Pleistocene) occur along the eastern edge of the county and in the Kissimmee Valley, but the unconsoliclated sands are the chief surface formation.

\section{ORANGE COUNTY}

Orange County lies chiefly in the Lake Region in central peninsula Florida. The eastern and southern parts are flat and underlain by unconsolidated sands and sandy clays of Pleistocene and Pliocene age : in the western portion the sediments are probably a little older, though only one exposure, a marly limestone outcropping near Rock Springs, ${ }^{1}$ carries diagnostic fossils. These show it to be of Miocene age. There are no lime deposits of commercial size in the county.

\section{OSCEOLA COUNTY}

Osceola County, lying just south of Orange County, is quite flat or gently rolling and affords but linited exposures. The surface materials are sands and clays of undetermined age; from well records, however, it is known that consilerable thicknesses of Pleistocene are present along the Kissinmee river and it is highly probable that these with some of Pliocene age, extend to the eastern border of the county. No lime deposits are known.

\section{PALM BEACH COUNTY}

Palm Beach County lies on the Atlantic coast in southern Florida. Consoliclated Caloosahatchee marl has been encountered under a relatively thin mantle of sand and muck in the western portion of the county and seems to underlie this whole area. On the St. Lucie canal near the locks at Lake Okeechobee this marl occurs under a sandy overburden of nine feet; the marl here is well consolidated and was used in the construction of the Conners highway.

In the eastern part of the county shell marls of Pleistocene age are fairly abunclant; in the vicinity of Lantana, a partially consoliclated

${ }^{1}$ Smith, E. A., Amer. Jour. Sci., 3rd Ser, vol. 21, pp. 302-303, 1881. 
sandy shell marl has been worked on a small scale as road material for local secondary roads and has proven quite successful.

In the extreme southeastern corner, the Miami oolite is present, though in this area it is probably too sandy, or contains too many sandy lenses to be capable of any extensive development. A narrow strip of sandy, fine-grained coquina extends intermittently along the coast the whole length of the county, forming the Blowing Rocks at Jupiter and the backbone of the islands in Lake Worth. In a road cut through the golf links at Palm Beach, twenty-three feet of this material can be seen in a sheer face; how much thicker it is cannot be determined, but alternating with sand lenses it may extend to a depth of forty-five to seventyfive feet. This sandy cequina has been little used, although some private driveways on Palm Beach have been surfaced with it.

Analysis of Coquina at Palm Beach Golf Links (Survey sample C-III). Silica $\left(\mathrm{SiO}_{2}\right) \ldots \ldots \ldots \ldots \ldots \ldots \ldots \ldots \ldots \ldots \ldots \ldots \ldots \ldots \ldots \ldots \ldots \ldots \ldots \ldots \ldots \ldots .12$

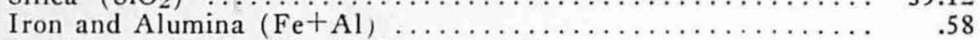

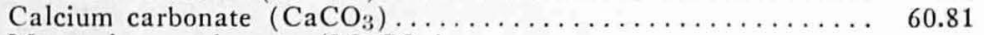

Magnesium carbonate $\left(\mathrm{MgCO}_{3}\right) \ldots \ldots \ldots \ldots \ldots \ldots \ldots \ldots \ldots \ldots \ldots \ldots \ldots$

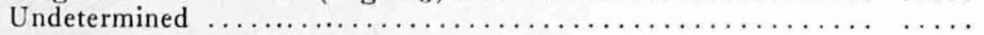

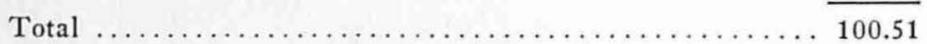

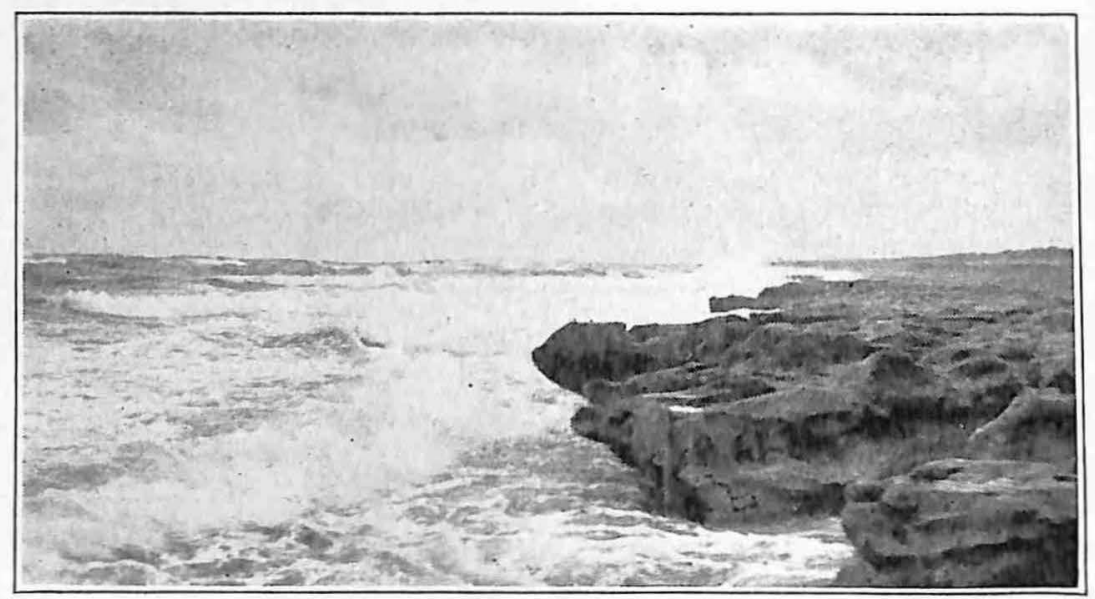

46a.-Sandy coquina near Blowing Rocks, Jupiter. 


\section{PASCO COUNTY}

Pasco County, on the Gulf coast in sonthern Florida, is chiefly underlain by the limestone of the Tampa formation, which outcrops on the westem border practically down to the water's edge In the northeast corner of the county the Ocala limestone is found. Many of the hills of the hammock belt in the interior or toward the eastern border are capped by the unconsoliclated sands and sandy clays of the Alum Bluff group.

Pasco County Road pit, fize miles south Aripcka-Limestone of the 'Tampa formation outcrops at the surface here and is worked to a shallow depth ( 3 to 5 feet) for use locally on the roads. The rock is semicrystalline and extremely hard; it is light buff to gray in color, and although quite compact is not uniformly so, because of the voids formed by the great numbers of fossil shells that have been leached out and only their impressions left. The rock occurs in large boulders free from any impurities; all the rock seen at this locality comes from a depth of not more than five feet, and might be more indurated by weathering agencies than the deeper lying material, but in general it is believed that the entire formation in this area will be much the same as the limestone described. though clayey pockets and soil debris may be encountered in a large deep pit.

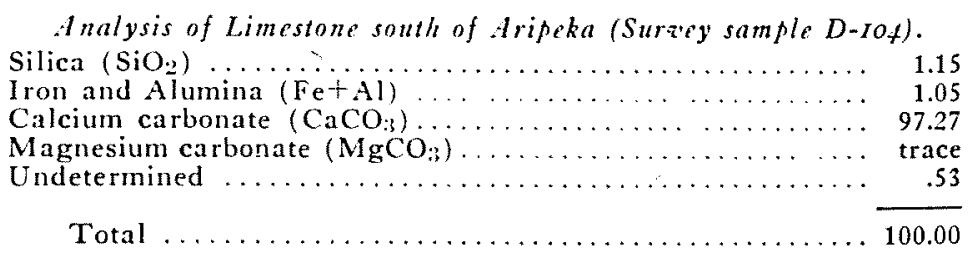

Pit of Mickler \& McLeod, one mile south of Lacoochee (now abandoncd)-Forty feet of the typical pure Ocala limestone is exposed in this large pit with only two to three feet of sand-clay overburden. The limestone is soft, white and compact, though the upper ten feet of rock seems slightly harder, owing to the cementing together of the masses of fossils that are very abundant here. Some clay pockets occur, and toward the bottom of the section a little flint. but these do not affect the quarrying operations or quality of the rock to any extent. 'The rock is used throughout this section of the State for road material. 


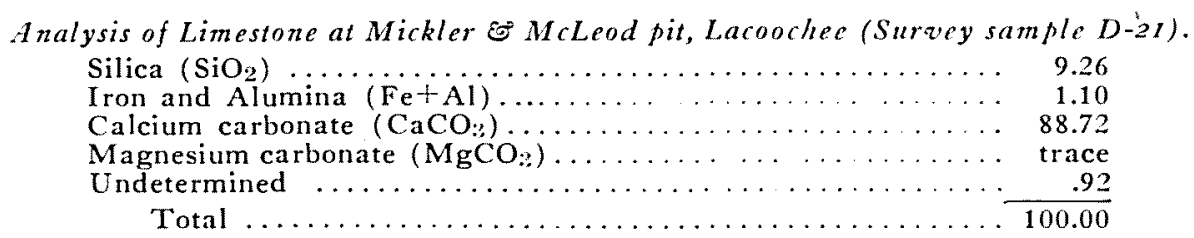

\section{PINELLAS COUNTY}

Pinellas County occupies the Pinellas peninsula in west-central Florida, lying between Tampa Bay and the Gulf of Mexico. Limestone of the Tampa formation outcrops in the northern end of the county around Tarpon Springs and Sutherland. The Alum Bluff (Miocene) outcrops near Indian Rock on the Gulf coast and probably tunderlies much of the county south of Sutherland, but it is not well exposed and the unconsolidated, sparsely fossiliferous formations are hard to recognize even when they are. The Caloosahatchee marl is exposed under six or eight feet of sand in the drainage ditches near Largo and is present over most of southern part of the county or peninsula where it is easily confused with the yellow-brown sandy shell marls of Pleistocene age which overlie it there.

\section{POLK COUN'TY}

Polk County lies in the central part of southern Floricla. The middle portion of the county is in the uplands of the Lake Region and in the southwestern portion is located the principal pebble phosphate producing section of the State. The Lake Region is underlain by sands and clays of undetermined age, though generally referred to the Alum Bluff (Miocene) ; the phosphate deposits are in the Bone Valley formation (Pliocene), a phosphatic conglomerate. Toward the Kissimmee river, the eastern margin of the county, some Pleistocene shell marls are found, but are not particularly abundant.

\section{PUTNAM COUN'TY}

Putnam County, in northeastern Florida, is entirely underlain by unconsolidated sands and sandy clays of Alum Bluff or later age, with the exception of a small area along the St. Johns River where the Nashuta marl (Pliocene) comes to the surface. No use has been made of the marl here, probably on account of the heavy soil mantle which covers it and the limited outcrops. Material from Recent shell (freshwater forms) mounds in the St. Johns river valley is used locally on the roads. 


\section{ST. JOHNS COUNTY}

St. Johns County lies in northeastern Florida between the St. Johns river and the Atlantic ocean. The land is flat and covered by a heavy mantle of soil and sand which masks the underlying beds except along the coast or in inlets. The beds thus seen consist of Pleistocene shell marls and coquina of the same age.

The coquina deposits of Anastasia Island have been known since the early days when the Spaniards quarried it, lightered it to the mainland and there used it in the massive structures of the fort and buildings of St. Augustine. The loose-shelled, unconsolidated coquina from Anastasia has in recent years been finding an increasingly important number of uses, as a concrete aggregate in place of gravel; mixed with tar or asphalt in road surfacing; and, probably most important, in the facing of artificial coquina building blocks and as the concrete aggregate in the same.

\section{ST. LUCIE COUNTY}

St. Lucie County, on the Atlantic coast in southern Florida, is immediately underlain by sands and shell marls of Pleistocene age. The county is quite flat and these marls are hardly ever seen naturally exposed unless near the seacoast; drainage canals near the towns of Fellsmere, Fort Pierce and Vero have turned up marls under a relatively thin cover, three to six feet of sand. The marls in the county are quite sandy and unconsoliclated and little use has been made of them except as material for secondary highways in some few places.

\section{SAN'A ROSA COUNTY}

Santa Rosa County lies in the pine hills of western Florida. The surface formations are all sands and sandy clays of undetermined age, but in all probalbility are mostly Pleistocene, particularly near the Gulf of Mexico, and Pliocene in the more northern portion toward the Alabama state line. No lime deposits are known to occur.

\section{SARASO'TA COUNTY}

Sarasota County lies on the Gulf coast in South Florida. The oldest and most widespread formation is the Caloosahatchee marl, which is present, near or at the surface, over the whole eastern half of the county. In the northwest section the phosphate-bearing Bone Valley formation is found. Along the coast and for several miles inland, Pleistocene shell marls are present under a thin sandy cover; most of these 
are of marine origin and consist of loose or partially consolidated shells and brown-yellow sand; they are considerably used for road material in the southern part of the county about Englewool. In the vicinity of Venice some hard, impure fresh-water limestone is found and used in the construction of the county highways. The rock is light to lark gray in color, impure and very hard; it is worked to a depth of four or five feet under a one-foot cover of sand.

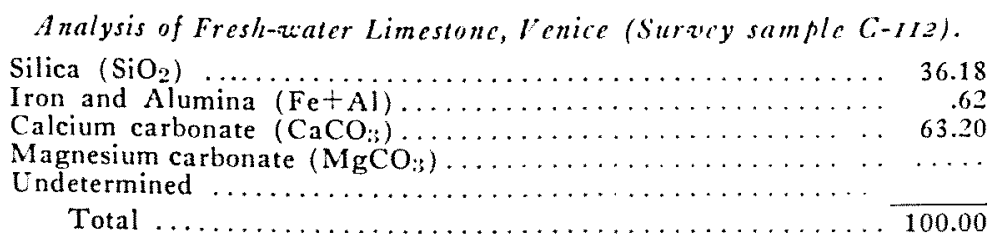

SEMINOLE: COUNTY

The formations exposed in Seminole County consist of sands and some clays and do not contain fossils whereby their age can be determined; in all probability the Alum Bluff (Miocene) unclerlies the western portion with the younger, Pliocene and Pleistocene, sediments coming into the section toward the east. No line deposits are known.

\section{SUMTER COUNHY}

The Ocala limestone outcrops at the surface or is present under a very thin cover over almost all of Sumter County, which is in the Gulf hammock and lime-sink region. Along the entire eastern borcler which extends a few miles into the lake region, some sands and sandy clays of the Alum Bluff are present, but by far the larger part of the county is underlain, at a workable depth, by pure soft limestone.

\section{SUWANNEE COUNTY}

The oldest exposed formation in Suwannee County, which is mostly: in the lime-sink region, is the Ocala limestone. It outcrops in a narrow strip along the Suwannce river from Ellaville sonthward to Dowling Park and thence southeastward directly underlying the whole southern portion of the county. Many small pits in this southern area have been worked for local road material, but only one, that of T. A. Thompson, operates continuously.

Pit of T. A. Thompson, $21 / 2$ miles west of Hildreth-Twenty-five feet of the typical Ocala limestone is here quarried under a two to foutfoot orerburden of gray-white sand. The rock is soft though compact. 
cream-white and quite pure. The whole formation is honeycombed with small solution holes usually one to two feet in diameter and four to twenty feet in depth; these holes are very irregular, usually standing vertically but often joining underground to form a connected series. anounting to a channel. Since they are filled with red sandy clay and debris, they must be cleaned out before the rock can be worked and so are a great nuisance to the operators.

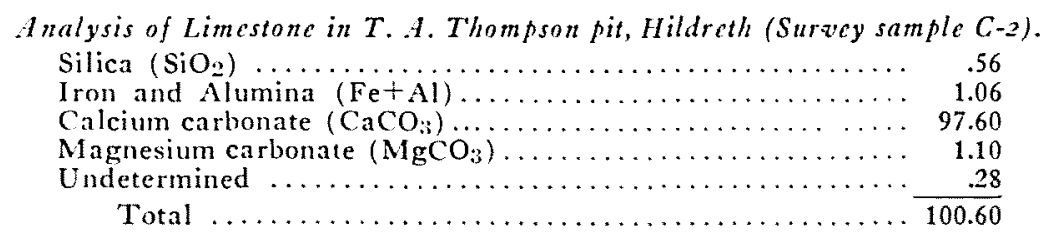

Result of six analyses by the Testing Division of the State Road Department:

Silica and insolubles $\left(\mathrm{SiO}_{2}\right)$ High Low $2.86 \quad 1.00$

Average Calcium carbonate $\left(\mathrm{CaCO}_{3}\right)$ Magnesium carbonate $\left(\mathrm{MgCO}_{3}\right)$

Resting upon the Ocala at Ellaville, outcropping all along the Suwannee river as far north as White Springs and underlying a large area in the central and northern portion of the county is the Glendon limestone. In West Florida this formation is usually soft and compact. but in Midrlle and East Florida it seems to be much harder, even semicrystalline in many places.

At the highway bridge over the Suwannee at Ellaville twenty-ont feet of the Glendon limestone is exposed above the stream level under a sand cover of twelve feet. The rock here is weathered and consequently quite indurated. It forms hard, jagged or rounded masses, light to dark gray in color. About five feet above water level a moss-covered protected ledge was found and from this the following sample taken. Here the rock is cream-white and soft, more compact than the Ocala, and has a coarser or more "platey" structure, due to the quantity of small fossils present. About one hundred yards up the river indurated rock has been quarried on a small scale, but the crusher is now abandoned.

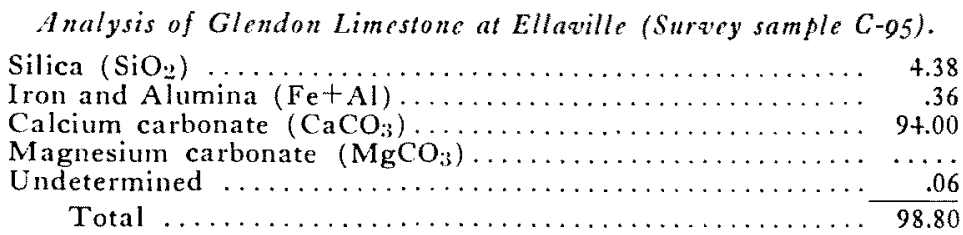


At Suwannee Springs, one of the many exposures on the Suwannee river in the northern part of the county, the Glendon limestone can be seen rising above the stream to a height of fourteen to seventeen feet under a cover of seventeen feet of sand. The upper five feet or so is considerably weathered and shows hard limestone embedded in a softer matrix, but the lower two-thirds of the section is hard, light to dark gray, semicrystalline material weathering into rough, jagged knobs.

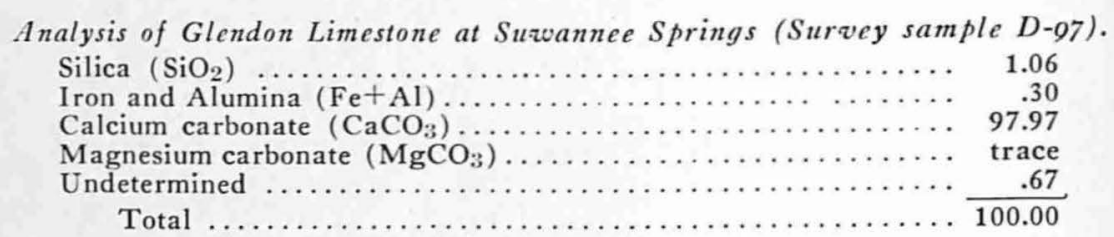

In the old Lyle quarry, now the property of the Southern Utilities Company, $1 \frac{1}{2}$ miles north of Live Oak, the Glendon has, in the past, been quarried for road material, railroad ballast and also for use in the manufacture of quicklime. The rock was quarried to a depth of fortyfour feet with an overburden of yellow clayey sand and red-gray mottled clay, five to six feet thick. The upper ten to fifteen feet of limestone is very soft, chalky and has much of the calcium carbonate leached out and redeposited at a lower level. The lower thirty to thirty-five feet is the hard, light-gray semicrystalline phase of the Glendon; the rock is not

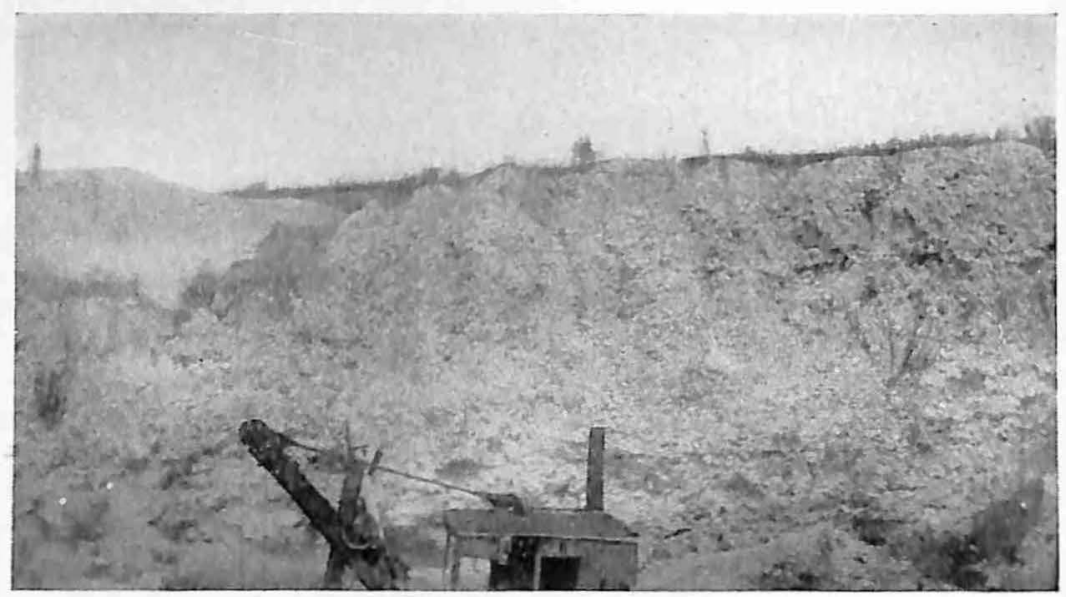

Fig. 47.-Glendon limestone in old Lyle quarry, Live Oak. 
entirely uniform, but is hardened in irregular connected masses or lenses with softer material scattered through.

Analysis of Limestone in Old Lyle Quarry north of Live Oak (Survey sample C-g6). Silica $\left(\mathrm{SiO}_{2}\right) \ldots \ldots \ldots \ldots \ldots \ldots . .66$

Iron and Alumina $(\mathrm{Fe}+\mathrm{Al}) \ldots \ldots . \quad .46$

Calcium carbonate $\left(\mathrm{CaCO}_{3}\right) \ldots \ldots .98 .70$

Magnesium carbonate $\left(\mathrm{MgCO}_{4}\right) \ldots \ldots$

Undetermined

.18

Total

100.00

French coefficient test. By Testing Division of the State Road Department.

Per cent of wear.......... 5.65

French coefficient ............ 7.08

The Glendon only extends a few miles east of Live Oak where it is overlain by the unconsolidated sands and sandy clays of younger age; these sands cover much of the northeastern portion of the county, hammock belt and fatwoods, and mask the underlying limestone.

\section{TAYLOR COUNTY}

Taylor County lies on the Gulf coast in central Florida between the Steinhatchee and Aucilla rivers and is mostly in the Gulf hammock region. In a very small area along the Steinhatchee river in the extreme southeastern part of the county the Ocala limestone is present at the surface. The rest of the county is underlain by an unknown limestone formation that, over the greater part of the county, is seen only in residual lime-flint boulders scattered through the thick soil mantle. Along the Aucilla river, about six miles northwest of Scanlon, many lime-sinks and natural bridges expose a soft cream to light yellow limestone that may be the main formation from which the impure boulders have come. At one of these natural briclges thirteen feet of soft rock was exposed under eight feet of sand and loam. This limestone is cream to white in color, chalk-like, uniform, and intermediate in texture between the Marianna and the Ocala.

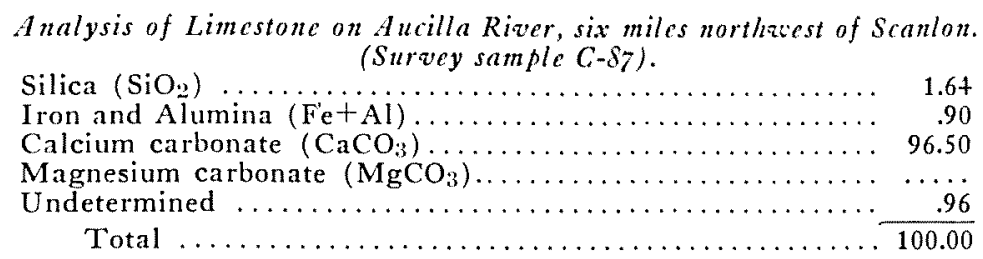

All through this section of the county flinty boulders are at the surface and have been utilized in road building in the southwestern end of the county. Along the Fenholloway and Econfina rivers hard, tawnycolored, flinty rock outcrops, but has not been used for any purpose. It 
is reported that the fresh material was at one time sawed out for chimney blocks.

The hard rock seen in the various stream beds as well as the hard boulders scattered through the soil in the central and southern parts of the county might well be the result of the weathering of the purer lime formation exposed on the Aucilla. 'The boulders in the northern part of the county have probably come from the Glendon limestone either as residual products or washed down from the more northern part of the State.

\section{UNION COUNTY}

Union County lies in northeastern Florida, mostly in the flatwoods. Practically the whole county is immediately underlain by unconsolidated sediments of Miocene and later age, but there are few exposures and no determinative fossils. In the extreme southwestern portion in the hammock belt, the Ocala limestone lies near the surface and may be at a workable depth.

\section{VOLUSIA COUNTY}

Volusia County is located on the Atlantic coast in the northern part of the peninsula and is mostly flatwoods. The oldest exposed formation is the Nashua marl (Pliocene), which underlies the entire western and much of the central part of the county. The marl is under a rather heavy sand cover over this entire area, but is well exposed in pits dug for road material at DeLeon Springs, DeLand and Orange City. In the eastern part of the county, sand and some Pleistocene marls are found; the latter have been worked to some extent near Daytona. Extending along the coast in a rather narrow strip are the coquina deposits: these are neither continuous nor uniform, but are found irregtularly all along near the shore front. Several natural exposures are seen near New Smyrna, Daytona and other places, but apparently the largest deposits are in the northern part of the county near Volusia where two large pits are worked commercially. Another source of lime in this county is the Recent shell mounds. Along the St. Johns river many of these are found and are worked for road material; they are made up of small fresh-water shells with a very small quantity of organic matter or debris and may be of considerable size, attaining a thickness of as much as twenty-seven feet and covering several acres. Deposits of these fresh-water shells are worked at Astor, Seville, near the river one and one-half miles west of DeLand fair grounds and many other places throughout the St. Johns 
valley. Near the coast Recent shell mounds are also found and used for road material. These shells, however, are all marine species, mostly oyster shells.

Property of the Ponce de Leon Springs Company, 1/2 miles southacest of $D \mathcal{C}$ Lcon Springs-About six pits have been opened here to work the Nashua marl for road material. In this area seven to ten feet of the marl is dug under a two to six-foot gray to brown sand overburden. The marl is cream to light yellow in color, rather compact in the bank and is predominantly composed of large massive shells and shell fragments in a matrix of clayey yellow sand and fine shell particles. It has been used extensively in local road construction and shipped to nearby places in the county.

Analysis of Marl at De Leon Springs (Survey sample C-122).

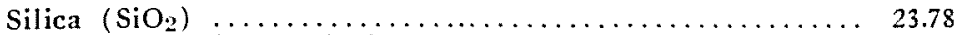

Iron and Alumina $(\mathrm{Fe}+\mathrm{Al}) \ldots \ldots \ldots \ldots \ldots \ldots \ldots \ldots, 2.70$

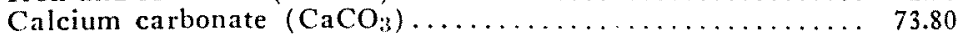

Magnesium carbonate $\left(\mathrm{MgCO}_{3}\right) \ldots \ldots \ldots \ldots \ldots \ldots \ldots \ldots \ldots \ldots \ldots$

Undetermined

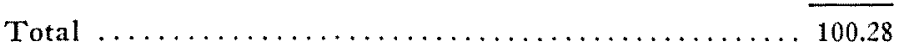

On the southern limits of DeLand are two abandoned marl pits, overgrown and partially filled in, which were formerly worked for road material. In the northern pit, belonging to the city, there is about seven feet of marl exposed under twelve feet of gray sand. The marl does not contain as many large shells or shell fragments as the DeLeon Springs material, but is a more intimate mixture of yellow clayey sand and fine shell fragments.

Analysis of Marl from DeLand City pit (Survey sample C-125).

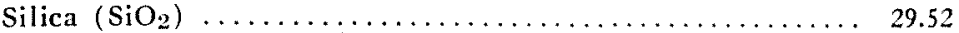

Iron and Alumina $(\mathrm{Fe}+\mathrm{Al}) \ldots \ldots \ldots \ldots \ldots \ldots \ldots \ldots, 1.72$

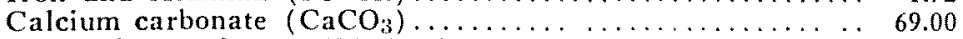

Magnesium carbonate $\left(\mathrm{MgCO}_{3}\right) \ldots \ldots \ldots \ldots \ldots \ldots \ldots \ldots \ldots$

Undetermined

Total

City-

Orange City road pit, $11 / 2$ miles northwest of Orange City-
Feet.

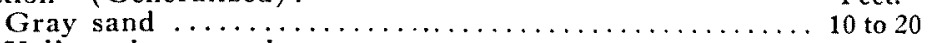

Yellow clayey sand $\ldots \ldots \ldots \ldots \ldots \ldots \ldots \ldots \ldots \ldots \ldots \ldots \ldots \ldots \ldots \ldots \ldots \ldots \ldots, 3$ to 5

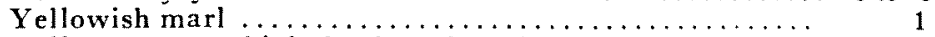

Yellow to gray thinly laminated sandy clay $\ldots \ldots \ldots \ldots \ldots$, 1 to $11 / 2$

Yellowish marl .............................. 5 
The lower marl bed is mostly an intimate mixture of finely broken shell and clayey sand, the upper marl bed seems to contain a few larger shells and shell fragments, but is otherwise the same. When the pit was worked for road material the whole body of yellow sand-clay and marl was used and not just the more calcareous marl.

Analysis of Marl at Orange City pit (Survey sample C-124).

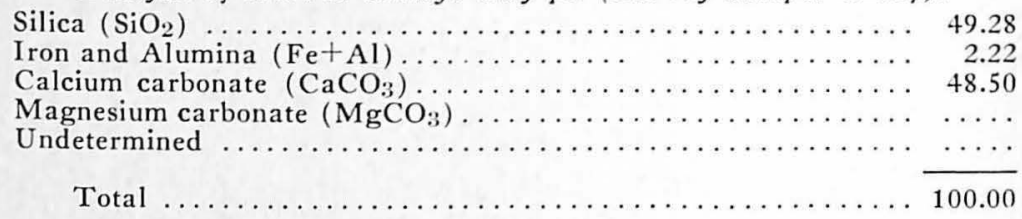

Near Volusia Station, in the extreme northeastern corner of the county, are located two companies that quarry the coquina rock, which occurs there in fine large deposits.

Pit of Halifa.r Rock Co., Volusia-The coquina in this pit is from four to twelve feet in thickness, averaging about nine feet. The rock is all very hard and compact and grades from the finely broken up closely cemented shell fragments to the coarser material with large shells almost intact; most of the material, however, is the finer grained, smooth-faced type.

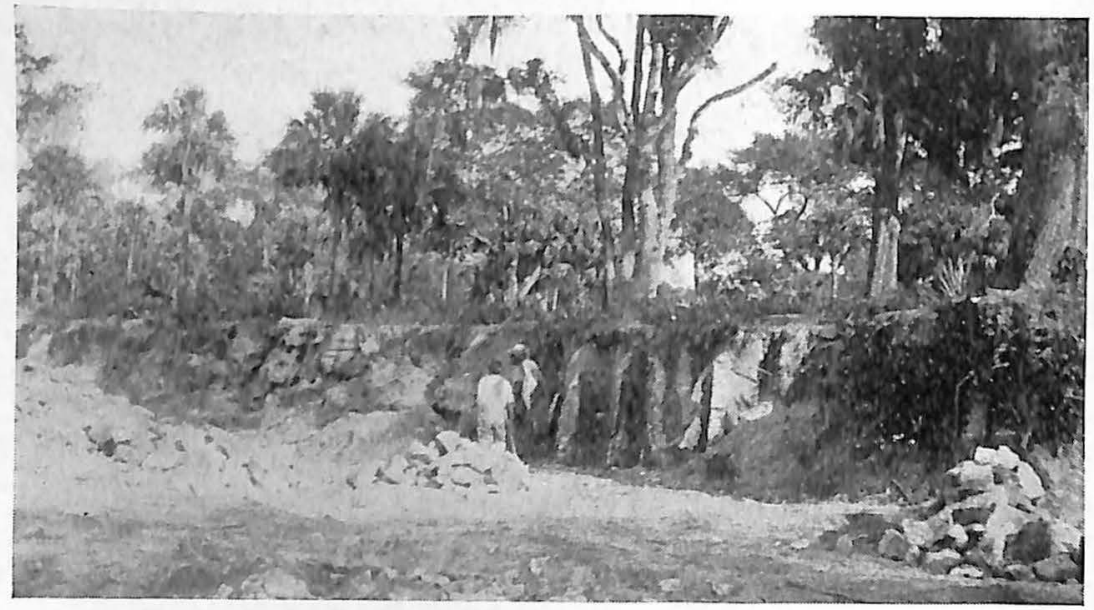

Fig. 48.-Digging Coquina in Halifax Rock Company's pit, Volusia. 
The pit is very large, covering fifteen or twenty acres. The rock is worked by blasting the face and then digging out by hand. A good deal of it is sold in slabs for house-building or other constructional uses, but most of the rock is crushed and used in road construction. Many of the hard-surfaced streets of Daytona, Daytona Beach, Ormond and Ormond lieach as well as many of the county roads, both surfaced and unsurfaced, are constructed with this coquina base. The pit has a producing capacity of fourteen carloads per day.

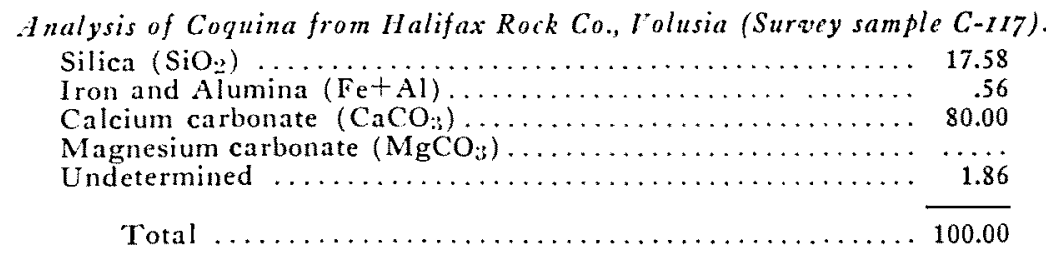

Coquina is composed, as can be seen from the above sample, almost wholly of quantities of calcium carbonate $\left(\mathrm{CaCO}_{3}\right)$ and silica ( $\mathrm{SiO} 2$ ). These will vary in every sample taken, even from the same pit, the general limits will be $\mathrm{CaCO}$, $75 \%$ to $93 \%$; $\mathrm{SiO} 2.10 \%$ to $25 \%$.

Pit of Volusia Coquina Rock Company, Volusia-This pit is quite similar to the one clescribed above. The rock is the hard compact building coquina, some of it rather coarse but predominantly the more smoothfaced type. It ranges in thiclness from two to nine feet, averaging about six, the principal use of the coquina is as road material, though much of it, in the uncrushed form, is sold as building material.

Analysis of Coquina from Volusia Coquina Rock Co., Volusia (Survev sample C-ItS).

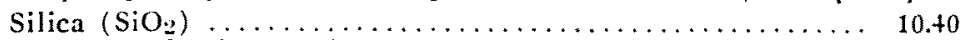

Iron and Alumina $(\mathrm{Fe}+\mathrm{Al}) \ldots \ldots \ldots \ldots \ldots \ldots \ldots \ldots \ldots \ldots \ldots \ldots \ldots .56$

Calcium carbonate $\left(\mathrm{CaCO}_{3}\right) \ldots \ldots \ldots \ldots \ldots \ldots \ldots \ldots, 90.46$

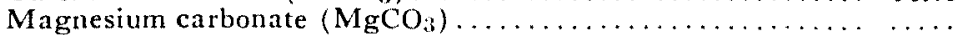

Undetermined

Total

101.42

\section{WAKULLA COUNTY}

Wakulla County borders the Gulf of Mexico and lies east of the Ocklocknee river. The eastem half of the county; in the Gulf hammock region, is underlain by a limestone of undetermined age, which is possibly closely related to the Chipola marl of Wiocene time; the western half is non-calcareous flatwoods, unclerlain chiefly by unconsolidated sediments of younger age. 
The limestone outcrops at the surface or is present under a thin sand covering all through the eastern section of the county; occasionally sink-holes also afford good exposures, but in many of these a thick mantle of soil and debris mask the underlying rock.

A particularly large open sink-hole about five miles west of Wakulla on the Crawfordville road shows six to ten feet of limestone above water level, under an eight to thirteen-foot overburden of sand and sandy clay. The limestone is soft, white to cream-yellow, with much yellow clayey material scattered all through. In some more exposed places it has weathered into a light gray impure limestone almost flintlike in hardness.

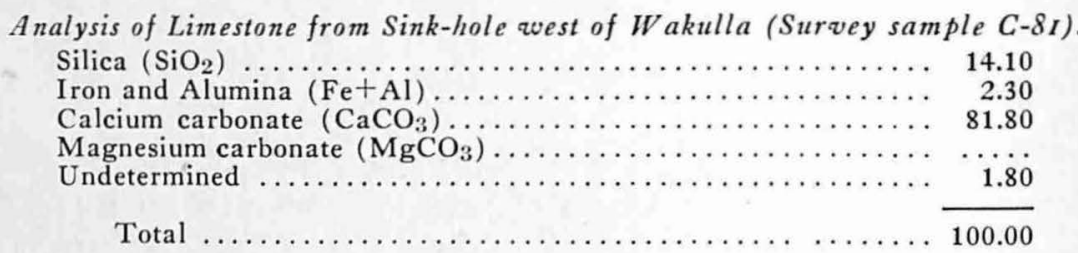

On the property of the Wakulla Turpentine Company, about threefourths of a mile northwest of Wakulla, is an abandoned limestone pit from which material was taken to build the Wakulla-Woodville road. This rock is the same limestone as seen in the sink-hole five miles west of

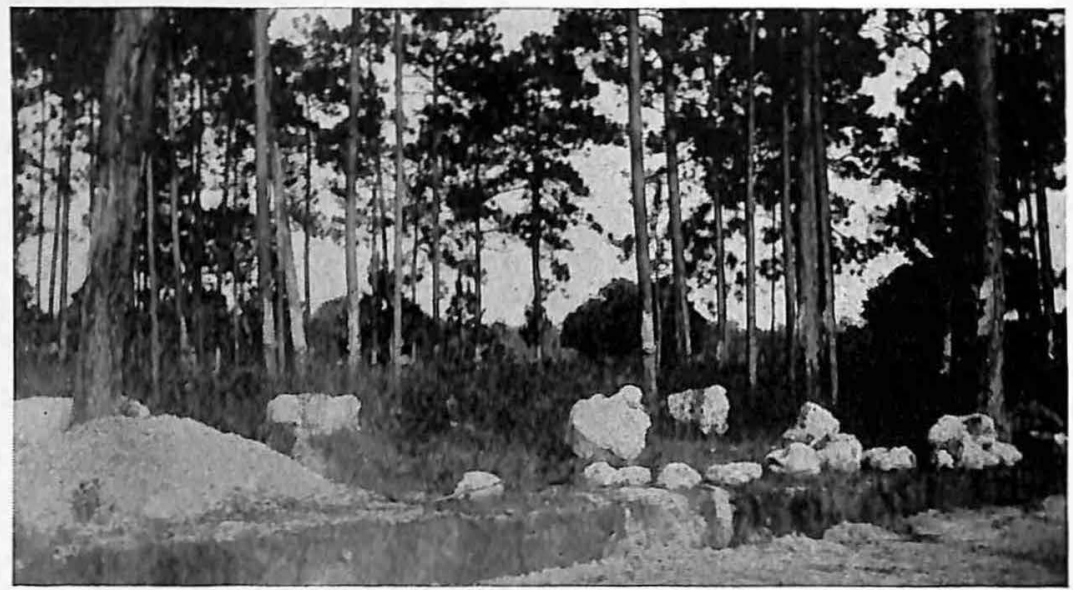

Fig. 49.-Boulders of limestone dug from shallow depth. Near Woodville. 
here and that underlies this whole section of the county, but in this instance the whole body of rock in the pit has been indurated to a hard material that rings under the hammer and breaks with a sharp, jagged edge. In the pit a foot and a half of gray sand overlies five feet of rock, dark cream-yellow to light gray-white. This same hardened rock outcrops in many places at the surface in this vicinity, but the actual depth to which it is hardened is unknown.

\section{Analysis of Limestone from Wakulla Turpentine Co., Wakulla} (Sturvey sample B-82).

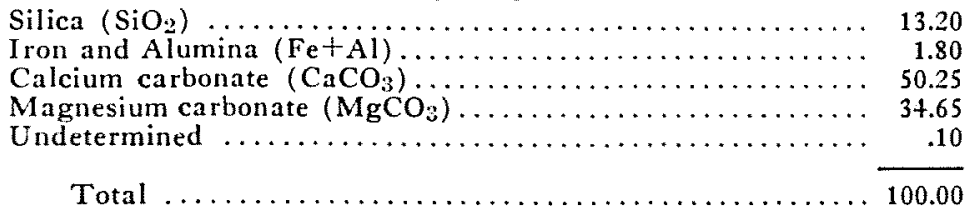

Along the Sopchoppy river a sandy phosphatic limestone ("Sopchoppy limestone") outcrops at the bridge one and three-fourths miles above the old Rouse place. About seventeen feet of this soft rock shows beneath eight feet of sancly overburden; the material is light gray to white in color, and quite sandy with many clay streaks running all through.

In the lower part of the section is a two-foot band of clayey material, below which many concretions are found.

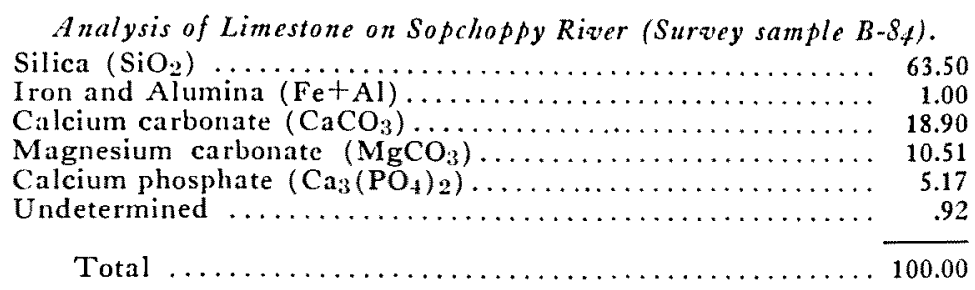

About two hundred yards clownstream from this section, on the opposite side of the river, shell marl is exposed in a sloping bank. At the water level the material is very sandy with a few shells, but a few feet higher in the bank the material is a soft, compact, light-yellow marl with a maximum thickness of probably not more than four to six feet. Since it occurs in a gentle sand-covered slope, the exact thickness of the shell marl and its relation to the limestone are unknown, but it may well be weathered material from the limestone. 
Analysis of Marl on Sopchoppy River (Survey sample $B-85$ ).

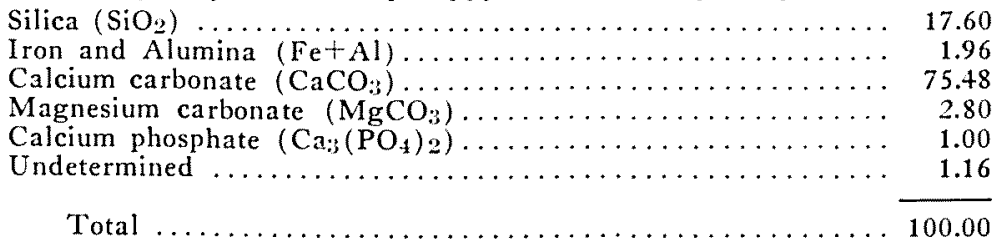

\section{WALTON COUN'TY}

Walton County is in West Florida and extends from the Alabama State line to the Gulf of Mexico and is mostly in the noncalcareous pinehill region. In the northeast corner of the county, near the State line, the Ocala limestone and a little of the Glendon formation are exposed at the surface. In the central part of the county is a belt of country immediately underlain by the marls of the Alum Bluff group (Lower Miocene); the type exposure of one of these marls, the Shoal River, is at Shell Bluff on the river from which it takes its name, about five miles north of Mossyhead.

The following section was taken at Shell Bluff :

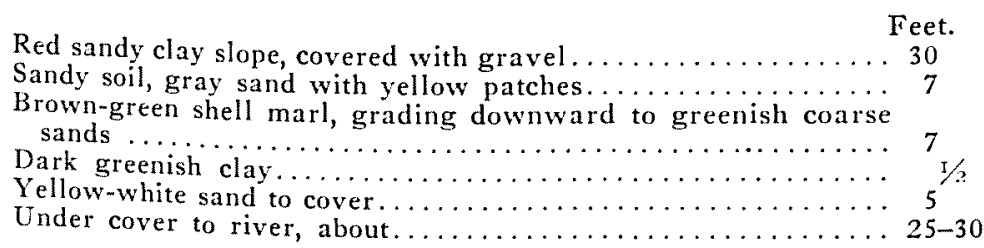

The top two or three feet of the marl is packed with shells, which become less numerous toward the bottom four to five feet of the marl until it becomes a sparsely fossiliferous green-brown clayey sand.

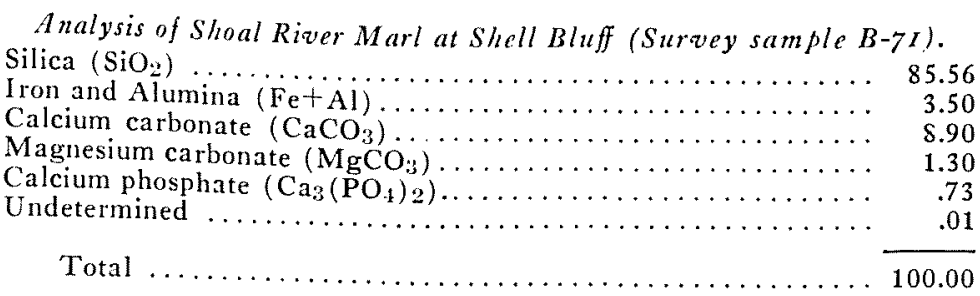

The $\mathrm{CaCO}:$ content will be higher and the $\mathrm{SiO} 2$ lower in the upper two or three feet of the marl. This was a fair sample from the whole 
seven feet of marl, the lower four or five feet of which is, as has been said, sparsely fossiliferous.

On White Creek, five miles south of Argyle, on the property of J. M. Armstrong, the Shoal River marl is again well exposed.

Section:

F'eet.

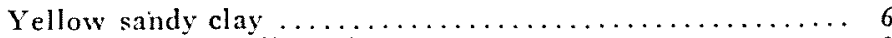

Yellow-brown shell marl........................ $31 / 2$

Blue-gray fine shell marl........................ 2 to water.

Analysis of Upper Shell Marl at White Creek (Survey sample C-7.3).

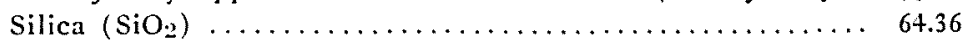

Iron and Alumina $(\mathrm{Fe}+\mathrm{Al}) \ldots \ldots \ldots \ldots \ldots \ldots \ldots \ldots \ldots \ldots \ldots \ldots, 6.14$

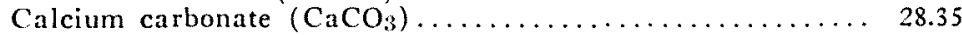

Magnesium carbonate $\left(\mathrm{MgCO}_{3}\right) \ldots \ldots \ldots \ldots \ldots \ldots \ldots \ldots \ldots \ldots \ldots$

Undetermined $\ldots \ldots \ldots \ldots \ldots \ldots \ldots \ldots \ldots \ldots \ldots \ldots \ldots \ldots \ldots \ldots \ldots \ldots \ldots, 1.15$

Total ................................. 100.00

Some phosphate is probably present, judging from the quantity of "Undetermined."

Analysis of Lower Shell Marl at White Creek (Survey sample B-73A).

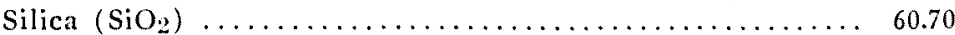

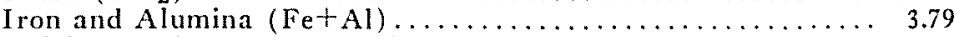

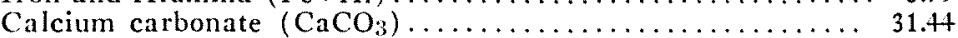

Magnesium carbonate $\left(\mathrm{MgCO}_{3}\right) \ldots \ldots \ldots \ldots \ldots \ldots \ldots \ldots \ldots, 2.50$

Calcium phosphate $\left(\mathrm{Ca}_{3}\left(\mathrm{PO}_{4}\right)_{2}\right) \ldots \ldots \ldots \ldots \ldots \ldots \ldots \ldots \ldots \ldots \ldots \ldots, 1.33$

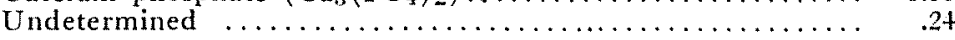

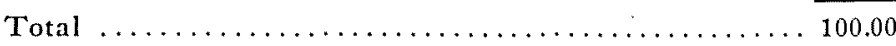

The lower shell marl or blue-gray material has been used by $\mathrm{Mr}$. Armstrong, the owner of the property, as a fertilizer and soil corrective and he believes that the land so treated has increased in productiveness. This same marl outcrops at other places along White Creek and also on Folkes creek, four miles south of Argyle.

At Red Bay, near the Choctawhatchee river, in the sontheastern part of Walton County, is found the type section of the Choctawhatchee marl.

Property of E. Gomillion, one-fourth mile cast of Red Bay-Nineteen feet of the Choctawhatchee marl is exposed here in a steep face at the base of a sloping yellow clay-covered hillside. The upper four to six feet of the marl is sparsely fossiliferous, but the lower part carries a profusion of small shell particles, with some larger shells and shell fragments all embedded in a dull greenish argillaceous sand. 
Analysis of Choctawhatchee Marl at Red Bay (Survey sample C-65).

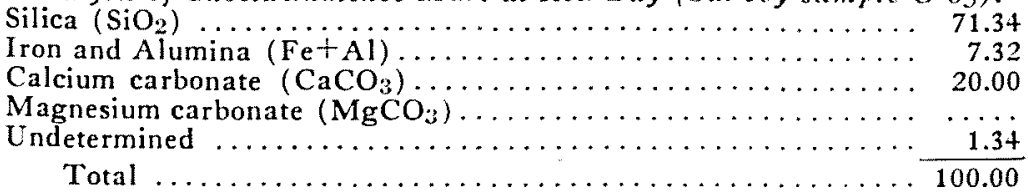

The "undetermined" content in all probability includes some small quantities of phosphate, potash, ammonia or other plant foods. Mr. Gomillion has applied this marl to several patches of land and states that there was a noticeable increase in productivity.

\section{WASHINGTON COUNTY}

Washington County lies in central West Florida, just east of the Choctawhatchee river. Most of the county is underlain by the Miocene marls, not well exposed, and the younger sands and sandy clays of Pliocene and Pleistocene age. In the northern, particularly the northeastern parts, are found excellent limestone deposits with only a thin overburden, the best field for development in this section of the State.

Property of Lon Parrish, three miles southeast of Wansan-Twenty feet of cream-white soft limestone is exposed in a sink at this location. This rather isolated limestone outcrop occurs in a belt of country underlain by the Alum Bluff marls and is rather unusual; the contained fossils indicate that it is older than the Chipola marl and probably belongs to the Tampa. The dimensions of the deposit are not known, but it is probably of only limited occurrence and does not cover a great deal of territory.

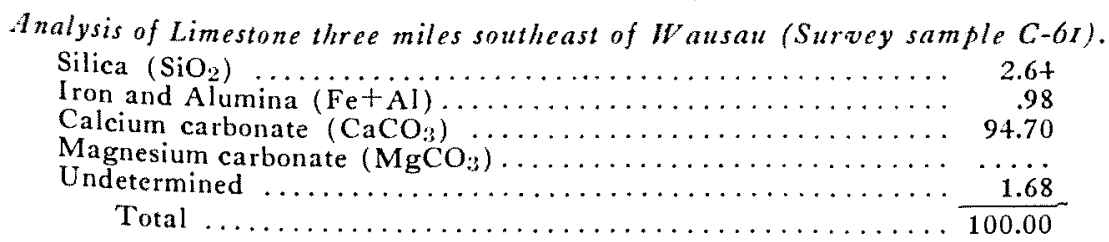

A small "island" of the Ocala limestone occurs around Duncan Post Office in the north-central part of the county. The rock is well exposed in sink-holes one-half to one mile west and south of the old post office site and has been cut ont with hand saws and locally used for many years as a building and chimney stone.

${ }^{1}$ Miss Julia Gardner, letters of May 6, 1925. 
Quarry on Marvin Owen property, one-half mile west old Duncan Post Office-About seventeen feet of the Ocala is exposed here in a dry sink-hole. The rock occurs in the bottom under a sloping bank of soil and debris, and from it have been cut many blocks for use throughout this region. The limestone seems very pure, and a little more compact and "set" than the loose, powdery material so often seen in this formation. In this instance, however, this compactness may be due to a slight degree of weathering of the smooth saw-cut faces.

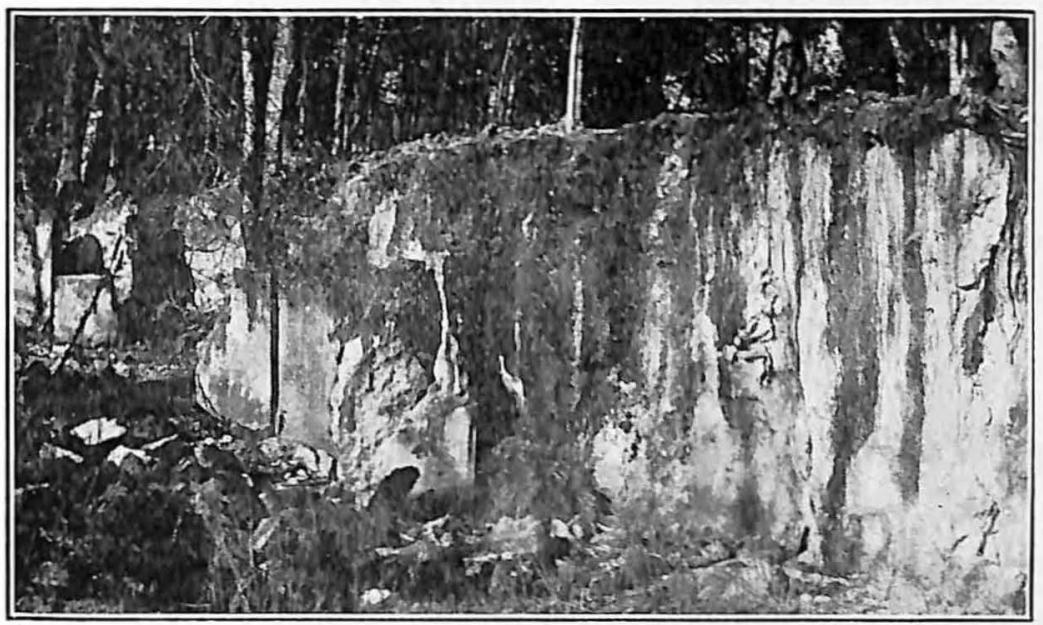

Fig. 50.-Ocala limestone near Duncan.

Analysis of Ocala Limestone at the Ozven Place (Survey sample B-60).

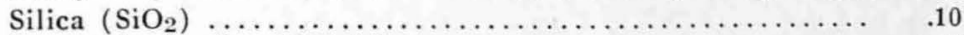

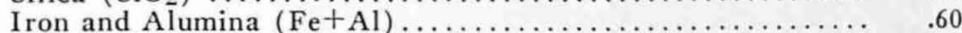

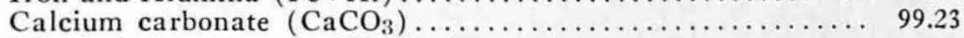

Magnesium carbonate $\left(\mathrm{MgCO}_{3}\right) \ldots \ldots \ldots \ldots \ldots \ldots \ldots \ldots \ldots \ldots \ldots$ trace

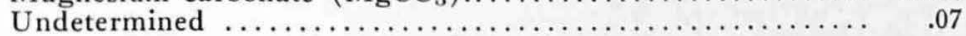

Total .................................... $\frac{100.00}{100}$

The country around Chipley, in northeastern Washington County, and for a few miles to the southeast and southwest, is underlain by a very pure soft limestone, the Glendon, which outcrops either at the surface or is present under a very thin sandy clay overburden. There has been no "development" of this rock and consequently no artificial exposures to aid in the study of it; sink-holes, however, are quite abundant and though many of them are too narrow and deep to permit entrance, 
some are easily accessible and it is from these that such knowledge as we have is obtained. In this area, the base of the limestone is unexposed and no accurate iclea of the th:ckness can be gotten. 'The greatest thickness seen is in the narrow cylindrical sink at Falling Water, four miles south of Chipley, where a sheer face of limestone $(61 \% 1 / 2$ feet is exposed. At present no use has been made of the extensive deposits of limestone in this region, but, no doubt, as hard-surfaced roads come in and building increases, many pits will be opened up, for the rock is of excellent quality for highway construction, agricultural lime, quicklime, cement and the countless other uses of a pure soft limestone. When seen at the surface or around the rims of sink-holes the limestone is tough, hard and cavernous, often present in large boulders; in more sheltered unweathered places it is soft cream-white in color with a peculiar compact, nonuniform texture, which might be described as "platey," i. e., it is soft under the hammer but breaks in irregular fragments with jagged edges. This seems due to the fact that the small hard particles (usually shell fragments or small foraminifera), which are present in great abunclance. have voids between them which are filled with soft amorphous lime.

Property of C. B. Dunn, two miles southwest of Chipley-Here in an amphitheatre sink is exposed thirty-eight feet of the Glendon limestone in the form of much weathered boulders, rough, jagged and flintlike in hardness.

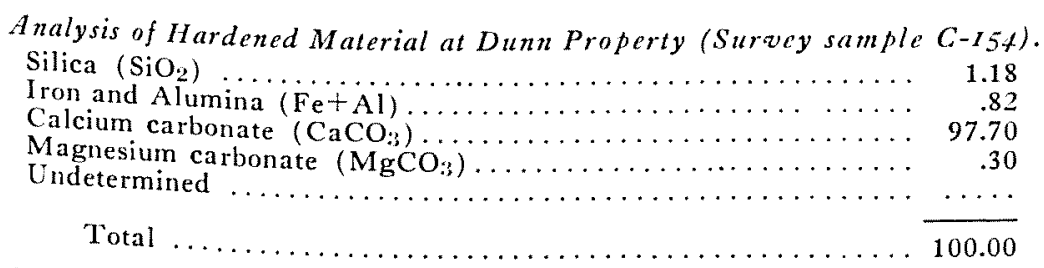

In the lowest part of the section, a shaft has been driven, by means of which a small quantity of limestone was taken out some years ago and burned with excellent results. The limestone thus matle accessible is the softer, less weathered phase.

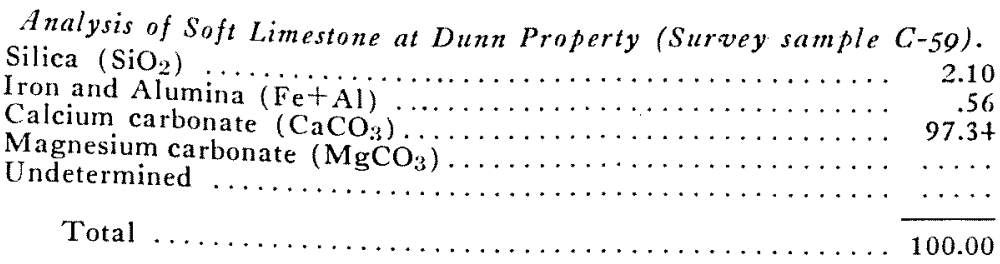


Property of B. M. Waldon, $31 / 2$ miles southeast of Chipley-Limestone outcrops at the surface all through the flat piney woods in this region. Many sink-holes. large and small, are present; the one from which this sample was taken was very narrow and steep, so that the bottom could not be reached; the exposed thickness of the soft Glendon limestone is about forty to forty-five feet. This section of country lies within a mile of the $\mathrm{L}$. \& $\mathrm{N}$. railroad, is flat, cut-over pine lands with very little undergrowth; the limestone outcrops at the surface, or under less than two feet of sandy clay overburden.

Analysis of Limestone on B. M. Waldon Place (Survey sample $C-74$ ).

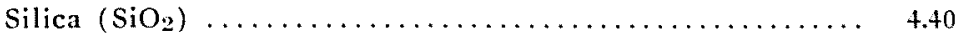

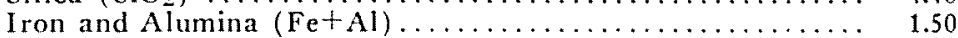

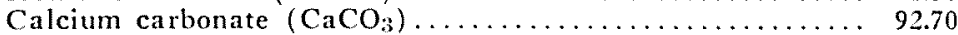

Magnesium carbonate $\left(\mathrm{MgCO}_{3}\right) \ldots \ldots \ldots \ldots \ldots \ldots \ldots \ldots \ldots . .83$

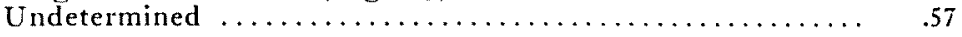

Total

100.00

W. T. Lancy property, three miles cast of south of Chipley-This property lies about three-fourths of a mile west or slightly northwest of the Waldon place just described.

Section :

Feet. Inches.

Red sand-clay in grass-covered sloping bank to edge of sink. 12

Glendon limestone

The soft Glendon limestone is exposed here in a large semicircular sink; the rock stands up in large boulders in almost sheer walls. A good cleal of the rock is weathered out hard and jagged, particularly the upper boulders forming the rim, but by far the most part exposed is the typical cream-white, soft, compact phase of the Glendon. Small irregular cavities carry debris and clay a few inches into the limestone, but in from the surface the rock is extremely pure.

Analysis of Limestone on Laney Property (Survey sample $C-75$ ).

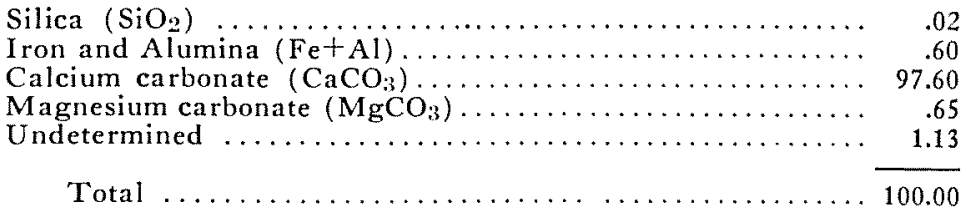




\section{GENERAL SUMMARY}

Crushed fint industry-Mention has been made in several places in this report of the chert and flint in the limestone and since this material is so closely associated with the rock and used in many places as a substitute, a short description of the chief flint producing section of Florida is inclucled here.

Chert or flint occurs associated in some degree with almost all the limestones of the State, but the flint production is practically confined to a small strip of territory in eastern Levy County from Raleigh to Morriston and perhaps extending a little into western Marion and northern Citrus counties. The flint is mined in this area to a very shallow depth since it occurs at or on the surface and never more than four or five feet deep. The occurrence is in boulder form and these boulders vary in size up to several feet in dimensions. The rock usually directly overlies the limestone, but sometimes the underlying material is clay-in a very few instances the boulders appear to be lying loosely in sand. The flint is clearly the result of the replacement of the Ocala limestone as it carries replaced fossils and oftentimes the boulders have an onter shell of fossiliferous limestone an inch or so thick. The chief or main occurrence of the flint rock is as a four or five foot stratum of irregular masses or boulders overlying the limestone and in turn overlain by a few inches of soil in places where the rock does not outcrop at the surface.

In 1917-18, cluring the war, this rock was mined and hand shaped flint brick for tube mill linings were made from it: this industry was abandoned, however, and the principal use now is making concrete aggregate and railroad ballast.

The method of working these surface boulclers is to send out wagons or trucks to collect the flint rock and hat it to the crusher. The larger boulders, or those more deeply embedded, are dug around and shattered by dynamiting and the small pieces thus obtained are loaded by hand. The flint is hauled to the plant and thrown into a gyratory crusher consisting of a large roughly conically shaped iron center revolving excentrically within an iron bowl. There is an opening of about one and a half to two inches between the center core and the bowl. at the base or thickest part of the center; the material after being crushed falls by gravity through this open space and is conveyed to the top of the building where it is dumped into an inclined revolving cylincler perforated for : 1. dust and screenings; 2 . one inch material; :3. one and a half to two 
inch material. The rock that does not fall through these openings into the respective bins, passes out and is automatically returned to the gyratory.

Because of the large areas that must be worked to secure rock, the crushers are of a portable type that can be taken down and moved without a great deal of difficulty. In addition to the chert and flint, some indurated surface limestone is often included by the men loading the trucks.

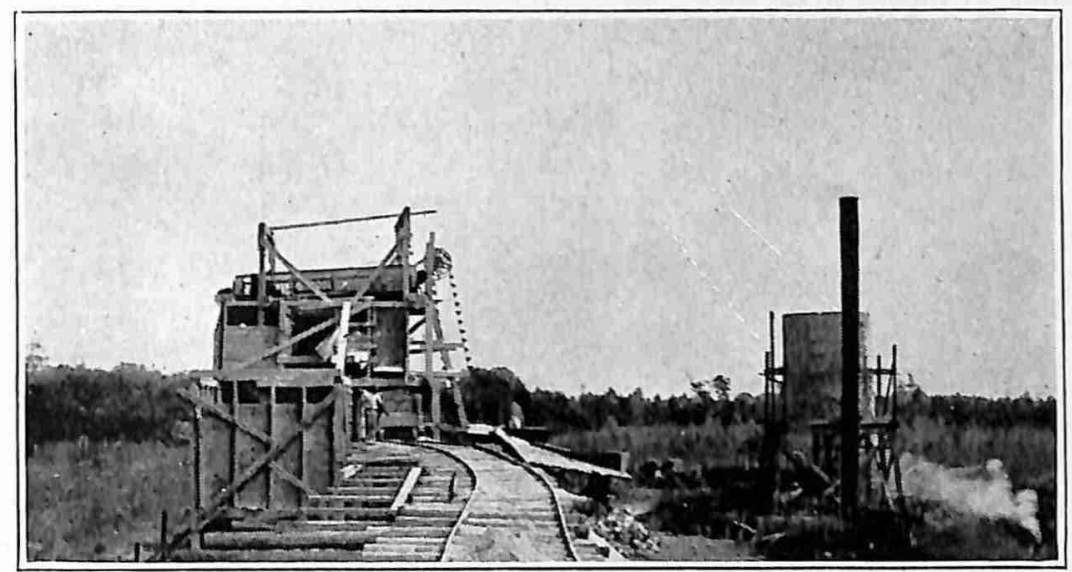

Fig. 51.-Flint crusher of Levy County Stone Co., Williston.

Until the last decade the history of the limestone industry in Florida might be termed the limestone industry of Ocala, for here mining and burning of limestone on a commercial scale had its inception in 1884 when the Ocala Lime Company began operations and this locality has been the center of activity ever since. Of course, Fort Marion at St. Augustine and many of the other original Spanish structures were of the famous coquina rock, and without a doubt the early settlers of the State manufactured lime for their own use and sawed out building or chimney blocks from the soft Ocala and Marianna limestones, but the first commercial development recorded is as mentioned above.

Until about 1915 Florida produced enough lime, building, hydrated, etc., for its own use and some was even shipped to nearby States. Since that time, however, and particularly within the last four or five years the production of lime has not materially increased and has not at all kept pace with the phenomenal growth of the State and its ever increas- 
ing building activities, so that to satisfy the clemands of the building trades as well as the different industrial needs, onc-half to two-thirds of the lime used has been brought in from Alabanat and Georgia. The reason for this apparent neglect of the burned lime industry is no doubt the interest and activity in supplying road material for state and county programs since the investment in a road material plant or cluarry is much smaller than in a burned lime plant, the experience necessary for operation not so great and the operator does not have the trouble of building up a market for his product. Many of the larger plants supplying road material own their own property and all equipment and market their product throughout several nearby counties until railroat rates become too high, but others operating on a small seale to furnish rock for road projects locally, lease property on a royalty basis and contract the different mining and hauling operations so that the business risks involved are reduced to a minimum that cannot be approached in the burned lime fields.

There are sixteen kilns operating in the State at the present time: these are confined to three companies and all burn the Ocala limestone. This rock is exceptionally pure, !) to 99 per cent calcium carbonate. but because of its softness and very low crushing strength offers a problem to the lime manufacturers and adds to the difficulty of burning. The method pursued is to mine the rock by hand and select the more compact pieces for burning. these lumps are broken to a size of four to ten inches in diameter and placed in the kilns. The kilns used are of the usual continuons. separate feed type but are of a low height, fourteen to seventeen feet, because if higher ones were used the weight of the additional rock would crush or break the unlerlying material and form a packed mass through which the hot gases could not penetrate. All the kilns in use in the State are of the same kind; these are marle of brick and have the open hopper at the top. At the bottom on each side are the fire box doors by means of which the fuel (woor) is fed, an arch over the fire prevents lime falling in and also prevents the discoloration of the lime by the hame. In a pit in front of the kiln, a few feet lower than the fire box, is a door where the burned lime is drawn out. The capacity of the kilns is fifty barrels per twenty-four hours and the usual practice is to draw half the kiln or twenty-five barrels every twelve hours. One company. has a rotary kiln. but this has not yet been thoroughly tested; it is reported that one burning of lime was tried, but apparently the material was not ground fine enough, for some of the rock pulverized in burning 
and formed a compact mass which prevented the cores of the larger pieces from being thoroughly burned. The company is now planning to grind the rock to a fine uniform mass and it is believed that this will result in a proper burning of the entire material. No attempt has been made to burn the harder limestones around Brooksville or Live Oak or to make similar use of the large tonnages of indurated surface boulders in the Marianna-Chipley area. This latter material is weathered from the soft pure Ocala and Glendon formations and in all samples taken maintains a very high calcium content, though physically it has been altered to a semicrystalline rock that could be crushed into the desired size for a rotary kiln and would not then pulverize in the process of burning and create the "fines" which make difficult the burning of the typical Ocala limestone.

The Tampa limestone in the Brooksville area is in all probability the best material for Portland cement manufacture, for this rock is not quite so high in calcium carbonate as the other formations in the State anrl consequently it will be easier to find a clay that will satisfy the required ratios than if a $90-98 \%$ CaCO rock were being used. infortunately most of the impurity in the Tampa limestone is in the form of silica (two to eight per cent), iron and alumina make up two to four per cent, magnesium is very low (less than one per cent) and will offer no difficulty. Physically the Tampa rock is harder and has a little higher specific gravity so that it will enter into the mix better and not be so apt to absorb moisture as would the lighter more porous Ocala rock. In addition to these more or less technical features the general distribution of the Tampa limestone is nearer the consumption center for cement and well situated for transportation, both by rail and water, an important point to consider since all fuel must be brought in. The most extensive clay deposits are in north and west Florida, but in the Brooksville area and the Lake Region to the northeast. good clay is found which might combine with the Tampa limestone to satisfy the desired ratio for cement. The main problem in locating a cement plant in the State is the discovery of a clay with a suitable chemical composition and it may be necessary to go to the western counties to find this.

The road material industry is centered around the town of Ocala in Marion County as is the lime burning industry, but many plants are scattered through the nearby counties- Hachua, Levy, Citrus, etc.mining rock from this same formation which has a rather wide distribution in the north central portion of the peninsula. The equipment for 
these plants and the method of working the pits are quite simple and have been briefly described in this report under "Marion County." The Miami oolite in Dade County is worked for road material at Ojus and Naranja and in Hernando County near Brooksville are two plants mining the Tampa limestone, some of which is utilized in road construction though it is a harder rock and also enters the construction field as concrete aggregate, railroad ballast, topping for private walks, railroad station platforms and other uses of a hard, clean crushed rock. Throughout southern Florida the different marls in various stages of consolidation are quite extensively used for road material locally and in the St. Johns river valley the fresh water shell mounds are being worked for the same purpose. Scattered along the Gulf and East coasts are the old Indian mounds composed of larger marine shells, mostly oyster, and many roads have been built of these; along the East Coast coquina is also employed. Thus it can readily be seen that almost all of the central and southern parts of the State have extensive deposits of calcareous materials of varying degrees of purity and hardness that can and have been utilized for the most important purpose of furthering the general welfare of the people by furnishing them with well constructed and up to date avenues of transportation. Oddly enough one of the largest potential limestone producing areas, the Marianna-Chipley section, has sand-clay roads and its calcareous deposits still remain untested. It is true that the Marianna "chimney rock" has quite a local fame and on a small scale has been widely used, but in this same region occur the larger and more extensive Ocala and Glendon limestones containing enomous tonnages of high grade rock for road material and other uses of a high calcium limestone. As west Florida grows, road building and general construction will find in northern Jackson and Washington counties large quantities of excellent limestone to satisfy their demands, a limestone which in every way will prove equal to the well known Ocala rock. 


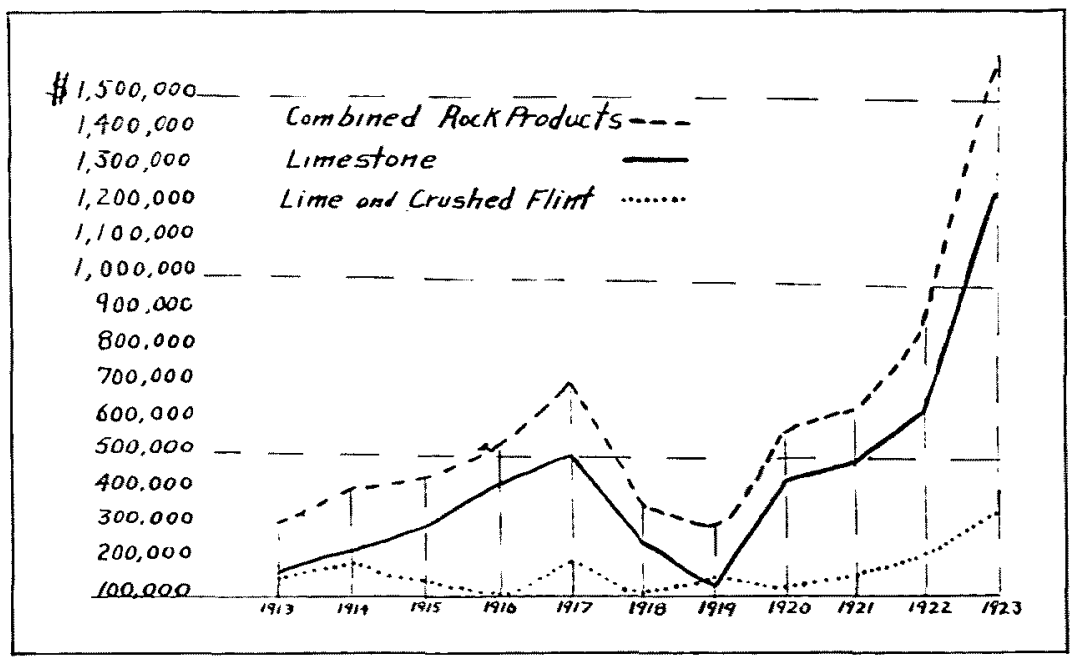

Fig. 52.-Graph showing value of limestone, lime and crushed flint produced in Florida 1913-1923.

The importance and growth of the limestone industry is graphically. illustrated above. Annual production figures are not available for the years prior to 1913, but the total value of rock products was probably not over $\$ 2,50,000$ for any one year. The Geological Survey does not publis? statistics of any mineral industry in which there is a limited (two or three) number of producers, hence it is not possible to show the lime inclustry in detail for the time shown on the graph, since during this lecade there were only two producers. However, the clotted line indicating "lime and crushed flint" is largely controlled by the lime production and this is seen to maintain a rather even trend over the entire period. mounting slightly and gradually in the last three years. The rise in 1917 was on account of the ontput of thint brick for tube mill linings which were manufactured luring that year in the Williston-.Xorriston area.

The main increase in the whole limestone industry is plainly shown to be in the raw limestone since 1919, and in the one year 1923 a tremendous growth can be seen. This is of course due to the use of this material in highway construction.

During the earlier years the separate curves are somewhat misleading because of the loose and arbitrary manner in which producers classified their product; in the last few years this has been remedied and a uniform classification adopted. 



\section{INDEX}

\section{A}

Acetic acid, acetone, 49

Acetrlene, its

Acid waters, soils, $36,+6$

Aeolian, 55

Agricultural limestone, lime, $45,+6,70$

Agassiz, A., 99, 102, 105, 108

Agassiz, L., 99, 102, 105, 108

Alabama, $49,68,73,87$

Alachua, 71

Alachua County, $70,74,115,116,117$

Alapaha River, $77,138,139$

Alaqua Creek, 89

Algae, lime secreting, $37,39,51$

Allen, J. H., 77

Altha, 121

Alum Bluff, $86,87,89$

Alum Bluff group, discussion of, 86,91

Alum Bluif group, $40,77,78, \$ 1,83, \$ 6$, $115,118,1-9,135,139,1+4,153,15+$, $155,150,157,158,167,172,174$

Ammonia, $38,+8$

Anastasia Island, $110,111,173$

Annuttiliga Hammock, $1+3$

Apalachicola River, $66,70,82,83,8+, 86$

Appropriations for Geological Survey, 7

"Arcadia" marl, 91

Arch Creek, 60

Archer, 117

Area of Florida submerged in Pleistocene time, 96

Argillaceous limestone, $+1,83$

Aigyle, 89,185

Aripeka, 171

Armstrong, J. M., 185

Arredondo Lime Compans, 115,117

Aucilla River, 87, 177

\section{$\mathrm{B}$}

Bacteria, 38, 39, 50, 51

Bahamas, limestone of, 37,39

Bahia Honda, 101, 109, 165

Bailey's Ferry, 87

Baker County, 117

Ballast Point, $79,81,1+4$

Ballasting rock, $43,70,77,81,101,107$

Barrier beaches, bars, 55

Bartow, 71

Basalt, 35

Baxley, W. H., 122

Bay County, 96, 117

Betts, 90, 117

Bellville, 138

Big Pine Keł; 101, 108, 109

Black Creek, 128
Bleaching powder, +8

Blowing rocks, 111,170

Blowers Lime \& Phosphate Company, $15+$

Blue Spring, $1+7$

Bone Valley formation, 139, 173

Bradenton, 157

Bradford County, 118

Brevard County, 118

Brick, production of, 18

Brooksville, $43,77,80,1+0,193,194$

Brooksville quarries, $1+1,1+2$

Broward County, 121

Brown, J. T., 108

Bruce Creek, 89

Buckman \& Pritchard, Inc., 19

Building stone, $t+, 71,73,77,101,107$, $109,111,113,173,193,19+$

Bureau of Census, L. S., Cooperation with, 17

Bureau of Soils, 11

Burton, M. R., $1+7$

\section{C.}

Caustic soda, soda ash, +9

Caverns, 59, 62, 70, 72, 101

Cement making, $45,70,77,82,85,193,19+$

Ceramics, 48

Cerithium rock, 78

Casa Marina, 166

Calcite, 36,56

Calcium carbide, +8

Calcium carbonate, 35, 37, 38, 50, 59

Calcium cyanamide, nitrate, 49

Calhoun County, 87, 96, 121

Caloosahatchee marl, 91, (fossils, 92), 93, $95,121,123,132,137,139,1+4,154$ $157,169,172,173$

Caloosahatchee River, 91, 97

Camp, C. \& J., $1+2$

Campellton, 73

Candles, 49

Cape Sable, 102, 105

Carbon dioxide, $35,38,50$

Carbonic acid, 36

Cartledge, G. H., $1+9$

Chalcedony, 79

Charlotte, 93, 123

Chattahoochee, 82,83

Chattahoochee formation, description and mention of, $82,84,86$

Age of, 83

Composition of, $8+$

Economic uses, 85

Thickness of, 84

Chattahoochee Landing, section at, 84 
Chattahoochee limestone, $41,7+, 79,82$, $84,121,134,136,156$

Chemical lime, $47,49,70$

Choctawhatchee River, 89

"Chimney rock", $4+, 71,73$

Chert, 40, 41, 74, 75,

Chipley, 62, 73, 75, 187, 189, 193, 19+

Chipola marl, 83, 87, 121, 122, 157, 181, 186

Chipola River, $68,71,72,87,89$

Choctawhatchee marl (fossils, 90), 89, $90,117,121,122,123,135,145,154$, 156,185

Choctawhatchee River, $66,75,87,88$

Citrus County, 70, 81, 124, 190

Clapp, F. G., 34, 68, 71, 78, 83, 86, 89 , 94,95

Clam shells, 36

Clarksville, 122

Clay County, 128

Clays, 35

Clay and clay products, 17

Clay testing laboratory, need for, 10

Coastal Plain, 53, 65

Cocoa, 120

Cocoa Beach, 111

Coconut Grove, 102

Coffee Mill Hammock marl, 97

Collier County, 98, 128

Columbia County, 129

Commercial Lime Company, 161

Concrete aggregate, $43,77,81,101,125$ $140,167,194$

Connell \& Schultz, 125, 126

Conner's Highway, 93

Conrad, T. A., 77, 99, 108

Cooke, C. Wythe, 3+, 68, 71, 73, 87

Coquina, $40,+4,55,110,119,133,173$ $178,180,181,191,19+$

Coral Gables, 107

Coralline limestone, 99, 100

Cornell University, 10

Cottondale, $73,145,149$

Crawfordville, 182

Cross-bedding, 53, 55, 109

Cross City, 133

Crystal River Rock Company, 43, 62, 63, $70,124,125,127$

Cummer Lumber Company, 115, 160

$\mathrm{D}$

Dade City, 81

Dade County, 129

Daffin, R. D., $1+6$

Dahle, Dan, 34

Dall, W. H., 68, 74, 77, 81, 82, 86, 89, 91,92

Dania, 103,121
Darlings Slide, 90,122

Davis, Newell B., 34

Daytona, 97,111

Daytona Beach, 111

Deadens (Washington County), 90

Deering estate, +4

DeFuniak Springs, 89, 90

Dekle, J. M., $1+8$

Dekle, M. L., $1+8$

DeLand, 94, 95, 178, 179

DeLeon Springs, 95, 178, 179

Delray, 110, 111

DeSoto County, 93, 132

Disappearing streams, 62, 70, 72

Distribution of reports by the Survey, 8

Dixie County, $70,132,153$

Dolomite, +1

Drainage canals, $6+$

Dredging, $6+$

Drew, G. H., 38

Luncan, 73, 186

Dunn, C. B., 188

Lunnellon, 77

Duval County, 19, 133

\section{$\mathrm{E}$}

Easi Cape Sable, 102, 105, 165

Eau Gallie, 111, 119

Econfina Creek, 90, 117, 118

"Ecphora bed", 89

Effect of solution on topography, $65,70,72$

Electrical porcelains, 19

Elevations, highest in Florida, 65

Ellaville, 74, 137, 175

Englewood, 17t

Eocene, description and mention of, 50, $66,68,71$

Erosion, 65, 66

Escambia County, 65, 96, 133

Establishment of Geological Survey, 7

Euchee (Bruce) Creek, 89

Everglades, 93, 98, 102, 105

Everglades, limestone in, $6+$

Examination of specimens, 9

Expenditures of the Survey, 12, 14

\section{$\mathrm{F}$}

Falling Water sink, 75

Fanning Springs, 117

Fay, Carl H., 119

Featherstonhaugh, G. W., 108

Fellsmere, 173

Fenholloway River, 178

Flagler Beach, 110,111, 133

Flagler County, 95

Flamingo, 105

Flint, $20,21,40,+1,+3,155,159,161,171$, 177,190 
Flood control, 10

Florida East Coast Railway, 101

Florida Keys, 99

Florida Lime Company, 63, 158, 160, 162, $16+$

Florida Rock Products Company, 79, 140

Florida Shell Rock Company, 155, 156

"Floridian" marls, 91

Foerste, A. F., 82

Folks Creek, 89, 185

Fort Lauderdale, 103, 104, 121

Fort Marion, $+4,111,191$

Fort Myers, 98, 15t

Fort Pierce, 97, 173

Fort Thompson, exposures near, 97, 139

Fort IVhite, 129

Fossils, 40, +5, 69, 71, 72, 86, 87, 90, 92

Fossil remains, 9

Four-Mile Creek, 90, 123

Franklin County, 96, 134

Fresh water shell mounds, 165, 172, 17s, 194

Fuller's earth, 18, 19, 80, $\$ 7,157$

\section{G}

Gabbro, 35

Gadsden County, 65, 83, 84, 87, 13t

Gainesville, 59, 62, 66, 70, 115

Gainesville Lime Rock Company, 116

Gardner, Miss Julia, 3t, 86, 88, 90,186

Geological formations of Florida, 67

Geological Survey, purpose of, 8

Geology of Florida, 65, 113

Georgia, 19, +9, 79, 96

Glades County, 93,137

Glass, 47

Glendon formation, description and distribution of, 7379,87

Economic uses, 77

Fossils of, 74,76

Limestone of, 43, 62, 83, 115, 121, 129, $132,13 \div, 136,1+5,137,139,151,153$, $157,175,178,187,193,19+$

Stratigraphic relation, $i+, 75,8 \overline{7}$

Glicerine, +9

Gneiss, 35

Gomillion, E., 185

Granite, 35

Gravel and sand, production of, 25

Griswold, L. S., 102

Ground water, 59, 62

Grottoes, 62

Gunter, Herman, 17, 3t

Gypsum, 38

\section{H}

Hague, 115

Halcyon Hall hotel, it
Halifax Rcck Company, 180, 181

Hall, H. A., 34

Hallandale, 121

Hardee Count;, 139

Harper, R. M., 34

Harris, G. D., 89

Hamilton County, 79, 129, 137

Hawthorne, 74, 115

Hawthorne formation, $74,86,87$

Hebron church, 127

Heilprin, Angelo, 68, 77, 91

Hendry County, 139

Hernando County, $70,77,81,139,141$

Hides, +9

Highlands County, 93, 1+t

High Springs, $74,77,115$

Hildreth, $17+$

Hillsborough Bay, 81, 96

Hillsborough County, 81, 87, 93, 1H

Hillsborough Inlet (Broward County), 101

Hillsborough River, 81

Holmes County, $75,76,1+5$

Holmes Creek, 87

Homestead, 103

Hovey, E. O, 108

Hunt, E. B., 99, 100, 108

Hydrated lime, $+6,+7,70$

\section{1}

Idaho, production of phosphate in, 22

Igneous rocks, 35

liluminating gas, 48

Ilmenite, 19

Imperfections in limestone, +5

lncreases in mineral production, 17

Indiana, 62

Indian Key, 100

Indian Kiver (itu, 110, 112, 119

Istacha:ta, $78,81,1+3$

\section{J}

Jackson Biuff, $90,15+, 156,157$

Jachson Coune, $70,71,73,76,1+5$

Jachsomille limestone, 89

Jefferson County, 6?, 87, 151

johnson, L. C., 87,88

Johnson, S. O., 108

fupiter, 111, 112

\section{K}

Kaolin, 17

Kendrick, 160, 161

Kentucky, 62

Kentucky, production of phosphate in, 22

Kerr, W. C., 77

Key Largo, 167 
Key Largo limestone, description and mention of $43,99,101,102,108,165$

Thickness of, 100

Fossils of, 100

Key Vaca, 100

Key West, 106, 108

Key West oolite, description and mention of, $40,100,102,108,109,165,166$

Distribution of, 109

Fossils of, 109

Thickness of, 108

Kissimmee River, 96

Kynesville, $1+5$

\section{L}

Labelle, 139

Laboratory for tesing clay, 10

Lockloosa, 115

Lacoochee, $1+7,171,172$

Lafayette County, 70, 153

Lake City, 129

Lake County, 95, 153

Lake Flirt marl, 97

Lake George Shell Corp., 165

Lake Miccosukee, 77

Lake Okeec lobee, 65, 91, 93, 97

Lake Region, 65

Lake Worth, 111

Laney, W. T., 189

Langdon, D. W. 82, 87

Largo, 172

Leaching of limestone, 62, 63, 69

LeConte, Joseph, 99, 105, 108

Lee, 157

Lee County. 98, 154

Leon County, $77,87,90,134$

Levy County, 70, 155,190

Liberty County, 65, 86, 156

Lime, 20, 21, 36, $+1,51$

Limelight, $\$ 8$

Lime secreting organis.ns, 36, 37, 50, 51

Limesione-Age of Florida, $53,65,66$ Agriculiural use, $+5,70$

Burning of, 192

Classification or varieties of, $39,40,41$

Composition, 35

Contact of Marianna-Ocala, 68, 71

Distribution of, 36

Formation of, 36, 39, 50, 51

Origin of Florida, 50

Production of, 20

Rate of solution of, 51

Of Southern Florida, 64

Structure of, 53

Texture of, 51,52

Uses of, 41, 50

Weathering of, 55,64

Live Oak, 43, 62, 66, 75, 77, 129, 176
Lloyd, 151, 153

Long Key, 102

Lubricants, +9

L.yle quarry, $+3,62,63,176,177$

Mc

McClelland, John, 87

McDonald, Wim. P., $1+t$

\section{M}

Madison County, 77, 157

Magnesian limesionc, $+1,48,84$

Manatee Counts, $87,97,157$

Mansield, IV. (., 95

Map showing mineral industries, 15

Marathon key, 109, 165, 166

Marble, 35

Marianna limestone, description and distribution of $+4,66,71,73,83,1+5$, $147,149,191$

Ecenomic uses, 73

Fossils of, 71,72

Stratigraphic relation, 71

Thickness of , 71, 72

Marion County, 70, 95, 158, 165, 190

Marion County Lime Company, 163,164

Marls, 35, 36, +1), 51,63,64,87,90,93, $96,97,118$

Marvland, 89

Matson, $\dot{G}^{\circ}$ C. $34,68,71,78,83,86,89$, 94,95

Maule, E. P., 130

Melbourne, 111,120

Melbourne Beach, 111

Merritts lsland, 118

Metamorphic rocks, 35

Miami, $+4,60,102,103,106,109,132$

Miami oolite, description and mention of $40,43,+4,55,61,100,102,107,108$, $121,129,130,165,170,19+$

Fossils of, $10+$

Origin of, 105, 107

Thickness of, 102, 103

Miami River, 102

Miccosukee Drain, 152, 153

Mickler \& McLeod, 1+4, 171, 172

Middleburg, 128

Miller's landing, 87

Milligan, 87

Mineral City, 19

Mineral production, 17, 25

Mineral specimens for examination, 9

Mineral waters, output of, 21

Miocene, description and mention of, 77 , $79,86,87,89,91,94$

Mitchell, Elisha, 77

Monazite, 19

Monroe County, 165 
Montbrook, 155

Morriston, 155,190

Mosquito Inlet, 111

Mossthead, $18+$

Murdock, 123

Museum, 9

\section{N}

Naranja, 102, 103, 106, 132

Nashua marl, description and mention of, $94,95,153,172,17 \mathrm{~s}$

Nassau County, 167

Natural Bridge, $70,149,150$

Natural bridges, formation of, $58,62,70$

Natural cave, 70,150

Newberry, 115

New River, 101, 102

New Smyrna, 111

Newfound Harbor Keys, 101

North Carolina, 89,98

"Dummulitic" limestone, 68

\section{$\mathrm{O}$}

Oak Grove, 167

Oak Grove sand, description and mention of, 86, 89, 167, 168

Ocala, $+6,63,66,68,70$

Ocala Lime Company, 191

Ocala Lime Rock Company, 158, 160, 162

Ocala limestone, description and distribution of, $40,+1,+3,44,+6,57,59$, $62,63,66,68-73,75,77,78,81-83$, $115,117,118,124,126,129,132,140-$ $145,153,155,158-16+, 174,175,178$, $18+, 186,187,190,19+$

Economic uses of, 70

Fossils of, 69

Stratigraphic relation, 71,87

Thickness of, 69,70

Ocheesee, "Ocheesee beds", 82, 83

Ocklocknee river, 87,90

Ojus, 43, 61, 103,121, 130,131, 194

Thickness of limestone at, 102, 103

Ojus Rock Company, 102, 131,132

Okaloosa County, 96, 167

Okeechobee County, 169

Oldtown, 133

Oligocene, description and mention of, $50,66,71,75,78,83,86$

Oolitic limestone, to

Orange City, $85,98,178-180$

Orange County, 169

Orbitoides limestone, 68

Origin of Florida limestones, 50

Ormond, 111

Orthaulax bed, 78

Osborn, E. A., 155, 156

Osceola County, 169
Owen, Marvin, 187

Oysier shells, 36

\section{$\mathbf{P}$}

Pablo Beach, 19

Palm Beach County, 19, 121, 169

Paint pigment, manufacture, $19,+9$

Palm Beach, sandy limestone near, 55, 111,170

Panama City, 117

Parrish, Lon, 180

Pasco County, 81, 171

Pavne's Prairie, 70,115

Peace River, 96

Peat, 21, 22

"Peninsular" limestone, 68, 71

Phosphate, 22-24

Phosphatic marls, 90, 91

Phosphatemining companies of Florida 24

Physical characteristics of limestones, +0

Pinellas County, 81, 93, 172

Pineola, 125

Pleistocene, description and mention of, $50,6+, 81,90,91,94,96-113$

Pliocene, description and mention of, 50 , $65,90,91,9+$

Polk County, 87, 172

Porcelain wares, 19

Portland cement, 45,70

"Pot holes", 54, 56, 57, 159

Potteries, 18

Precipitation of calcium carbonate, 36 , $37,38,51$

Pronto Springs, 136

Publications of the Geological Survey, 8

Purpose of the Geological Survey, 8

Putnam County, 94, 95, 172

Quartzite, 35

Quicklime, 46, 47, 70,73, 77, 82

Quincy, 71

\section{R}

Rabb's valley, 72,149

Railroad ballast, $43,70,77,81,101,107$, $125,140,167,194$

Rainwater, 36

Raleigh, 190

Rate of solution of limestone, 51

Recommendations, 9

Recrystallization, 63

Red Bay, 89, 90, 185, 186

Reddick, 181

Redeposition, 63, 69, 101

Reports of the Survey, distribution of, 8

Richland, 81

River Junction, 82, 84, 136 
Rivers, 36

Road material, $42,70,73,77,81,93,95$, $101,107,112,113,125,140,167,172$, 193,194

Rock Bluff, 83, 87

Rockledge, 119

Rock Spring, 169

Rocks, classification of, 35

Rouse property, 183

Rutile, 19

Saddle Bunch Keys, 109

St. Augustine, 44, 191

St. Johns County, 173

St. Johns River, 94, 95, 96

St. Lucie Canal, 92, 93, 169

St. Lucie County, 173

Salt, 38

Sand and gravel, production of, 25

Sand-lime brick, 25, 47

Sandstones, 35

Sanford, S., 34, 68, 99, 101, 102, 105, 108

Santa Rosa County, 96, 173

Santa Fe, 115

Santos, 162

Sarasota, 110

Sarasota County, 93, 97, 98, 110, 173

Scanlon, 177

Schist, 35

Scott, Bryan, 117, 118

Secondary deposition, 62, 63, 101

Seaweed, sea plants, 37

Sedimentary rocks, 35

Sellards, E. H., 86, 97

Seminole County, $17+$

Senterfitt Creek, 88, 167

Sexton, P., 147

Shaler, N. S., 102, 105

Shell Bluff, $88,89,18+$

Shell marl, 97, 98, 118, 121, 123, 132, 133, $134,137,139,154,157,165,169,173$

Shoal River, 88

Shoal River marl, description and mention of, $86,88,89,18+, 185$

Silver Springs, 70

Sink holes, $59,62,65,75,90$

Six-Mile Creek, 81,144

Slag, 42

Soaps, 49

Soils, 36, 46

Soil corrective, 90,123

Soldier Key, 101

Solubility of limestone, $36,50,51,55,62$, 64,101

Sopchoppy, limestones near, 87,183

Sour soil, 46

Southern Florida, 37, 38, 39, 50,51, 64
Smith, Buckingham, 102

Smith, E. A., 68, 169

Smith, N. R., 38

Spark plugs, 19

Spaniards, 111

Spate, M. A., 149

Specimens sent in for examination, 9

Sponges, 41

Springs, 70,72

Spooner, G., 150

Stanley-Brown, J., 83, 89

Statistics on mineral production, 17-25

Steinhatchee River, 177

Streams, 36

Stream gaging, 10

Structure in Florida, discussion of, 66

Stuart's Mill, 167

Sugar refining, 49

Summary of mineral production, 25

Sumter County, $17+$

Sutherland, 81

Suwannee County, $66,70,75,79,153,17+$

Suwannee River, $74,75,77$

Suwannee Springs, 75, 137, 176

\section{$\mathrm{T}$}

Table of Geologic formations in Florida, 67

Tampa, 78

Tampa Bay, 79

Tampa formation, description and mention of, $43,+5,77-81,83,87,124,127$, $140,14+171,172,186,193,19+$

Economic uses, 81,82

Fossils of, $78,79,81$

Stratigraphic relation, 78,83

Tanner's grist mill, exposure at, 88,167 , 168

Tanning, 49

Tarpon Springs, 81,172

Taylor County, 133, 177

Ten-Mile Creek, 122

Tennessee, production of phosphate in, 22

Tests by State Road Department, 115, $125,126,130,131,133,14+156,160$, $162,164,175$

Texas, 19

Titanium oxide, 19

Thompson, T. A., 174

Topographic mapping, 10

'Topography, 65, 70, 72

Tortugas Laboratories, 38

Tournley property, 143

Tuomey, M., 77, 99, 102, 108

U

Union County, 70, 178

United Clay Mines Corporation, 17 
United States Bureau of soils, 11

United States Geological Survey, 10, 17, 22

United States Bureau of Plant Industry, 38

Uses of limestone and lime, $+1-49,70,73$

\section{V}

Varieties of Florida limestones, to

Vaughan, T. Wayland, $51,61,86,87,88$, 89,105

Vegetable matter, 36

Venice, $98,17+$

Vero, 97,173

Vicksburg limestone (group), 68, 71, 75, 83

Virginia, 62,89

Volusia County, 95, 178

Volusia Coquina Rock Company, 181

Volusia, quarrying coquina near, 111

\section{W}

Waccamaw marl, 95

Waddell's Mill Pond, 70, 73, 148

Wakulla, 154,182

Wakulla County, 62, 66, 87, 96, 15t, 181
Wakulla Turpentine Company, 182, 183

Waldon, B. M., 189

Walton County; $89,90,96,184$

Washington County, 73, 76, 186-189

Water power development, 10

Water softening, 48

Wausau, 186

Welch, C., 149

Well records, 70, 78, 94, 95, 100, 108

White's Creek, 89,185

White Springs, $7+, 87,129,137,175$

Whiting, Henry, 99

Wilcox, Joseph, 115, 117

Williston, 155

Windley's Island, 166

Withlacoochee River, 77

Wood alcohol, 49

Woodville, $15+$

Wyoming, production of phosphate in, 22

$$
\mathrm{Y}
$$

Yellow River, 87,88

Zircon, 19, 20

Zuber, 160,162 


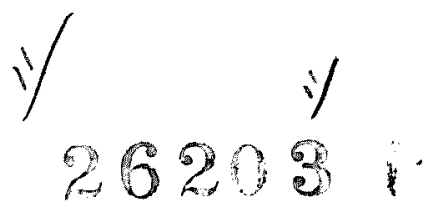






